\title{
The nature and origin of the REE mineralization in the Wicheeda Carbonatite, British Columbia, Canada
}

\author{
By
}

Joel Trofanenko

\begin{abstract}
A thesis submitted to the Faculty of Graduate Studies and Research in partial fulfillment of the requirements for the degree of Master of Science
\end{abstract}

Department of Earth and Planetary Sciences

McGill University, Montreal, QC, Canada

December 2014

(C) Joel Trofanenko 2014 


\begin{abstract}
In response to rising demand of the rare earth elements (REE), recent exploration of the British Columbia alkaline province has identified the Wicheeda Carbonatite, which contains an estimated 11.3 million tons of light REE-enriched ore grading 1.95 wt.\% TREO, to be the highest-grade prospect known in British Columbia. However, research of the deposit is restricted to one paper describing mineralization in carbonatite dikes adjacent to the main plug. This study describes the nature and origin of REEmineralization in the Wicheeda plug.
\end{abstract}

The carbonatite was emplaced in metasedimentary limestone and argillaceous limestone belonging to the Kechika Group, which has been altered to potassic fenite immediately adjacent to the carbonatite and to sodic fenite at greater distances from it. The carbonatite comprises a ferroan dolomite core, which passes outwards gradationally into calcite carbonatite. Three texturally distinct varieties of dolomite have been recognized. Dolomite 1 constitutes most of the carbonatite; Dolomite 2 replaced Dolomite 1 near veins and vugs; Dolomite 3 occurs as a fracture and vug-lining phase with the REE mineralization. Stable carbon and oxygen isotopic ratios indicate that the calcite carbonatite is of mantle origin, that Dolomite 1 is of primary igneous origin, that Dolomite 2 is largely primary igneous with minor hydrothermal signature contamination, and that Dolomite 3 is of hydrothermal origin. Rare-metal mineralization in the deposit is, with the exception of pyrochlore, which occurs in the calcite carbonatite, restricted to veins and vugs in the dolomite carbonatite. There it occurs as hydrothermal veins and in 
vugs infilled by REE-fluorocarbonates, i.e., bastnäsite-(Ce), ancylite-(Ce), and monazite(Ce) together with accessory pyrite, barite, molybdenite, and thorite.

A model is proposed in which calcite carbonatite was the earliest magmatic phase to crystallize. The calcite carbonatite magma saturated with niobium relatively early, precipitating pyrochlore. The magma later evolved to a dolomite carbonatite composition which, upon cooling exsolved an aqueous carbonic fluid, which altered the Kechika metasediments to potassic fenite and mixed with formational waters further from the carbonatite to produce sodic fenite. This fluid mobilized the REE as chloride complexes into vugs and fractures in the dolomite carbonatite. Upon progressive fluid-rock interaction, the REE precipitated largely in response to cooling and $\mathrm{pH}$. Hydrothermal concentration led to remarkable grade consistency, with virtually all of the dolomite carbonatite containing $>1$ wt.\% TREO, making the Wicheeda Carbonatite a very attractive exploration target. 


\section{Sommaire}

En réponse à la demande industrielle croissante pour les éléments du groupe des terres rares (ETR), l'exploration de la province alcaline de Colombie Britannique a récemment permis d'identifier la carbonatite de Wicheeda (11.3 millions de tonnes de minerai enrichi en terres rares légères, affichant une teneur de $1.95 \%$ TREO (l'oxide des terres rares total) comme l'un des prospects de terres rares les plus prometteurs. Les précédentes investigations menées sur ce gisement se limitent aux rapports des compagnies ayant exploré la zone pour ses ressources potentielles en terres rares. La présente étude décrit la minéralisation en éléments des terres rares de la carbonatite de Wicheeda, et combine l'étude de données pétrographiques et géochimiques dans le but de développer un modèle génétique pour ce gisement.

La carbonatite de Wicheeda s'est mise en place dans les formations de calcaires métasédimentaires et calcaires argileux du Groupe de Kechika, qui ont été altérées en fénite potassique au contact de la carbonatite et en fénite sodique de manière plus distale. La composition de la carbonatite montre une évolution graduelle depuis son cœur (dolomite ferrifère) vers sa périphérie (carbonatite calcitique). Trois variétés de dolomites ont été distinguées sur la base d'évidences texturales. La dolomite 1 est le composant principal de la carbonatite, la dolomite 2 remplace la dolomite 1 à proximité des veines et des pores. La dolomite 3 se met en place en fracture et en remplissage de la porosité, et accompagne la minéralisation en terres rares. Les ratios des isotopes stables du carbone et de l'oxygène indiquent que la carbonatite calcitique est d'origine mantellique et la dolomite 1 d'origine ignée. La dolomite 2 montre une signature ignée faiblement 
modifiée par l'altération hydrothermale subséquente et la dolomite 3 est d'origine hydrothermale.

Un modèle est proposé dans lequel la carbonatite calcitique est la phase magmatique la plus précoce. Cette phase a atteint la saturation en niobium très tôt, entrainant la précipitation du pyrochlore. Le magma a évolué plus tardivement vers une composition de carbonatite dolomitique qui, lors de son refroidissement, a exsolvé un fluide aquocarbonique altérant les métasédiments de Kechika en fénite potassique et se mélangeant avec les eaux formationelles, plus distales, pour produire les fénites sodiques.

Le fluide aquo-carbonique a mobilisé et transporté les ETR sous la forme de complexes chlorurés, au sein de la porosité et des fractures de la carbonatite dolomitique. A la suite des interactions fluide-roche prolongées, les ETR ont précipité du fait du refroidissement et de l'augmentation du $\mathrm{pH}$; la présence d'apatite a entrainé la formation de monazite(Ce). La concentration hydrothermale a permis une répartition homogène des teneurs, avec la carbonatite dolomitique contenant dans son ensemble plus de $1 \%$ TREO, faisant de Wicheeda un gisement très attrayant.

\section{Contributions of Authors}

This thesis has been written in manuscript format in accordance with the regulations put forth by the Faculty of Graduate Studies and Research at McGill University. It contains one manuscript submitted to Economic Geology. In addition, there are two supporting chapters and eleven appendices. 
The manuscript (Chapter 2) is entitled "The nature and origin of the REE mineralization in the Wicheeda Carbonatite, British Columbia, Canada" and is co-authored by Joel Trofanenko, Anthony E. Williams-Jones, and George J. Simandl. It includes descriptions of the Wicheeda Carbonatites and fenites, and the associated rare metal mineralization, as well as an interpretation of their origins.

Joel Trofanenko mapped the available outcrops and collected diamond drill core data during the summer of 2013. Anthony Williams-Jones, Duncan Mackay, and George Simandl provided valuable advice and scientific discussion during field investigations and Williams-Jones during laboratory research at McGill University. Trofanenko conducted the sample preparation, petrographic examination, geochemical analyses and data interpretation with guidance and assistance of Williams-Jones. Trofanenko prepared the first draft of the thesis, which was subsequently revised based on comments by Williams-Jones. Williams-Jones helped edit the final version of the thesis.

\section{Acknowledgments}

I would like to express my sincerest thanks to my supervisor, Professor A.E. WilliamsJones, for his guidance, support, and continued enthusiasm over the course of the project. His role as a mentor encouraged, challenged, and inspired me during my time at McGill. I am indebted to him for his incredible depth of knowledge and support for the past two years. I could not have completed this thesis without him. 
I am also thankful to the British Columbia Geological Survey for the opportunity to do mapping of the rugged British Columbian wilderness in an age of remote sensing. I wish to thank Spectrum Mining Corp. for providing access to the field area, drill core, geochemical data and internal reports and to Bob Lane of Brocade Metals Corp. for his invaluable knowledge of the property.

Lang Shi provided me with endless hours of expertise, often at the expense of his Saturday mornings, in the electron microprobe facility at McGill University, for which I am grateful. Jeanne Paquette also provided helpful advice and discussion, which contributed to this thesis.

The support provided to the author by the Targeted Geoscience Initiative 4 (2010-2015), a Natural Resources Canada program carried out under the auspices of the Geological Survey of Canada.

Finally, I would like to thank my peers and family for their continued support throughout the project. 


\section{Table of Contents}

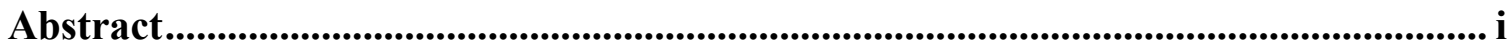

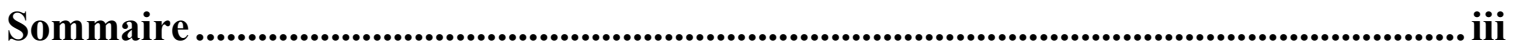

Contributions of Authors ............................................................................................... iv

Acknowledgments ........................................................................................................... $\mathrm{V}$

Table of Contents ................................................................................................................ vii

List of Figures..................................................................................................................................... viii

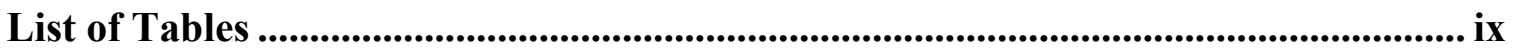

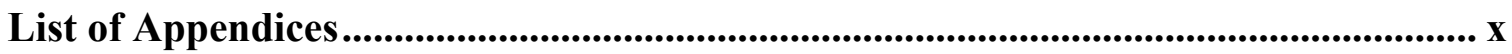

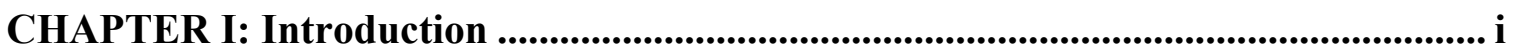

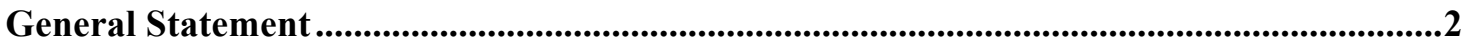

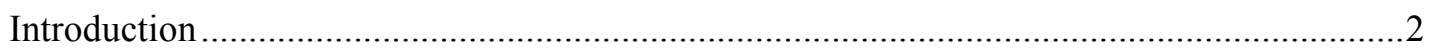

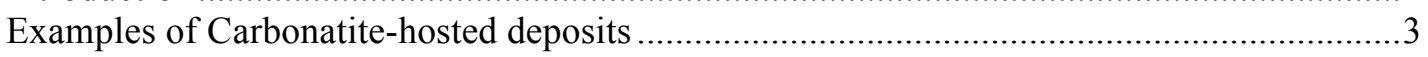

The tectonic setting and origin of carbonatite magmas ........................................................

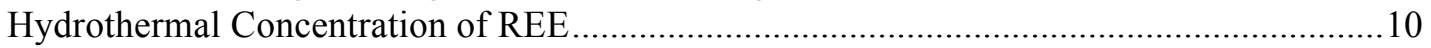

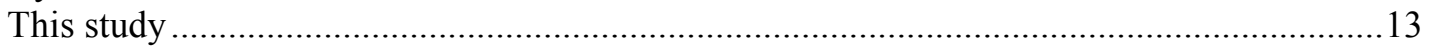

Previous Work

CHAPTER II: Journal Manuscript ................................................................... 30

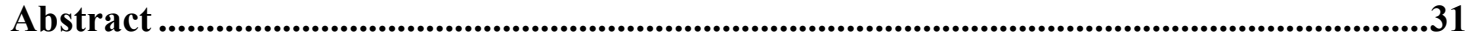

Introduction ...................................................................................................................................33

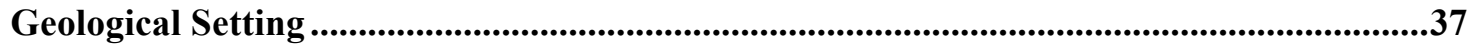

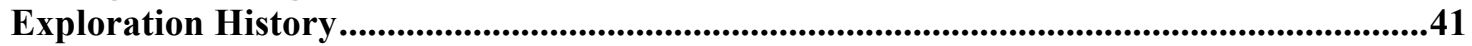

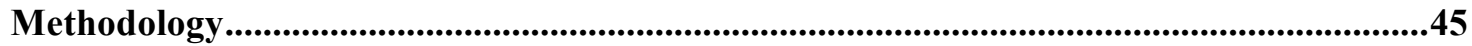

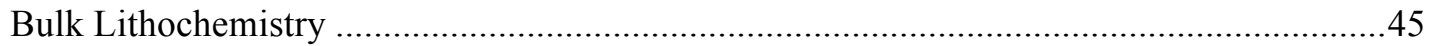

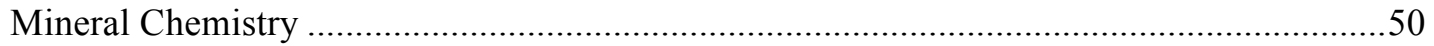

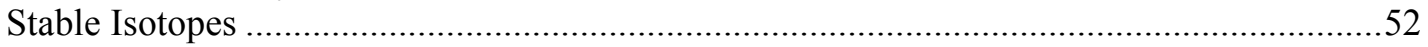

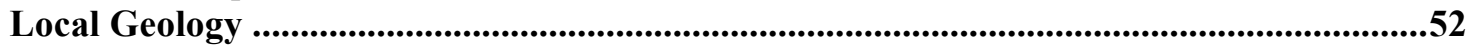

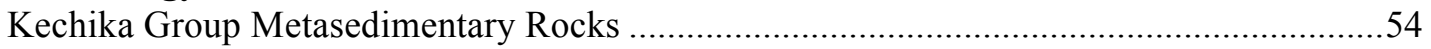

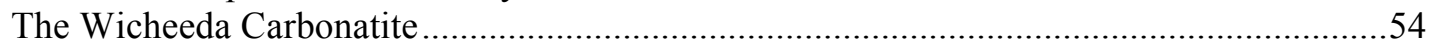

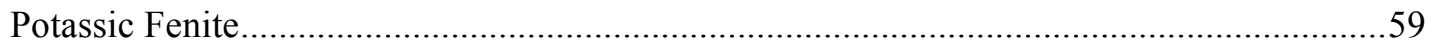

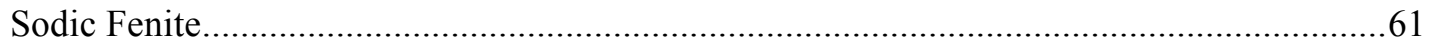

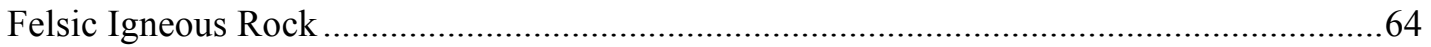

Rare Earth Element Mineralization ...............................................................................64

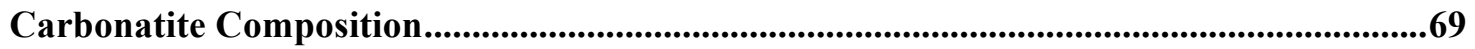

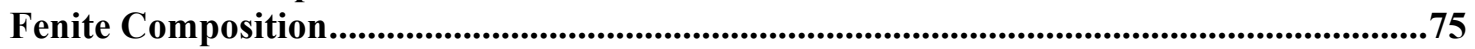

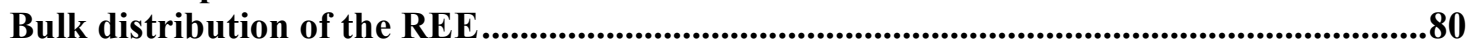

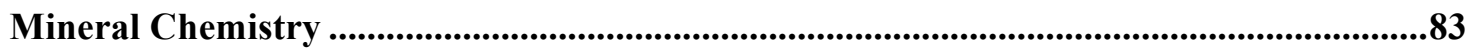

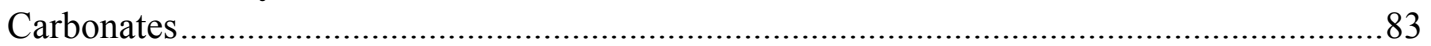

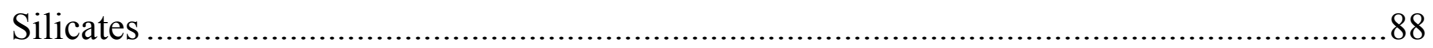

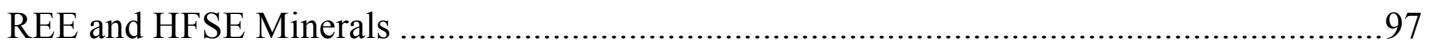

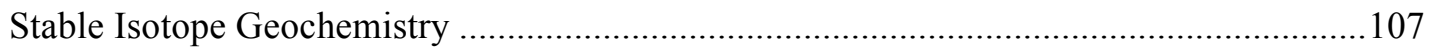

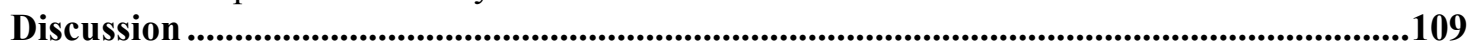

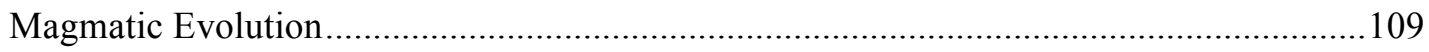

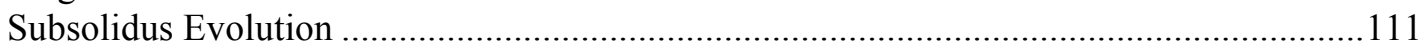




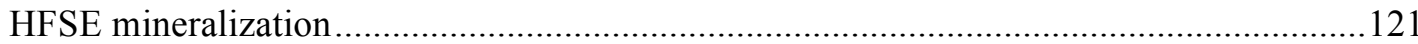

Genetic Model ...............................................................................................................................127

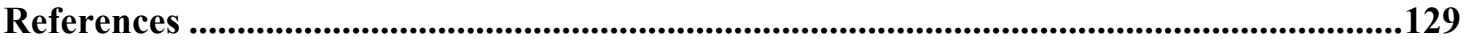

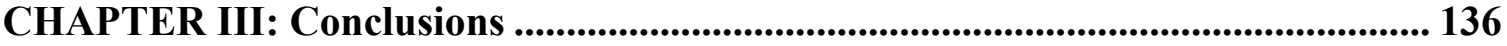

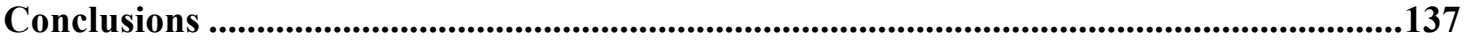

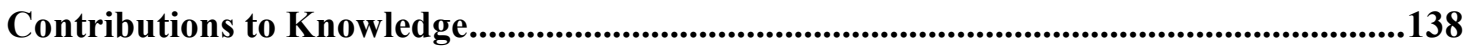

Appendices................................................................................................................................ 140

\section{List of Figures}

Fig. 1: A map of British Columbia showing the location of the British Columbia alkaline province and the most important rare-metal deposits. ....................................... 36

Fig. 2: The location of the Wicheeda Carbonatite and other nearby carbonatite and alkaline silicate dikes and sills within the Foreland belt sedimentary succession.... 40

Fig. 3: A magnetic gradient map of the Wicheeda Complex from Dalsin (2013) prepared for Canadian International Minerals Inc. by Aeroquest International Ltd............... 44

Fig. 4: Geological map of the Wicheeda Carbonatite and environs. ............................. 53

Fig. 5: A-D. Photographs and back-scattered electron images of dolomite carbonatite... 56

Fig. 6: A-D. Photographs and back-scattered electron images of calcite carbonatite. ..... 58

Fig. 7: A-D. Photographs and back-scattered electron images of potassic fenite............. 60

Fig. 8: A-D. Photographs and back-scattered electron images of sodic fenite................. 63

Fig. 9: A-F. Back-scattered electron images of dolomite carbonatite. ........................... 66

Fig. 10: Paragenetic diagram showing the order of crystallization of the main REEbearing and associated minerals in the Wicheeda Carbonatite...............................6 68

Fig. 11: The distribution of Wicheeda Carbonatite compositions (molar proportions) on the $\mathrm{CaO}-\mathrm{MgO}-(\mathrm{FeO}+\mathrm{MnO})$ carbonatite classification diagram of Gittins and Harmer (1997).

Fig. 12: The TREO content (wt.\%) of the Wicheeda Carbonatites as a function of the bulk molar ratio, $\mathrm{Fe} /(\mathrm{Fe}+\mathrm{Mg}+\mathrm{Mn})$

Fig. 13: A chondrite-normalized spider diagram illustrating the distribution of trace elements in the Wicheeda Carbonatites. The data were normalized to CI chondrite (McDonough and Sun, 1995)....

Fig. 14: A chondrite-normalized REE diagram for the Wicheeda dolomite carbonatite and calcite carbonatite.

Fig. 15: A plot showing the compositions (wt. \%) of potassic and sodic fenites in terms of the components, $\mathrm{Al}_{2} \mathrm{O}_{3}, \mathrm{Na}_{2} \mathrm{O}$, and $\mathrm{K}_{2} \mathrm{O}$.

Fig. 16: A chondrite-normalized spider diagram illustrating the distribution of trace elements in the Wicheeda fenites and Kechika argillaceous limestone.................... 78

Fig. 17: A chondrite-normalized REE diagram for the potassic fenite, sodic fenite, and Kechika argillaceous limestone.

Fig. 18: A bar graph showing the total REE content in weight percent of the carbonatites and fenites. B. A bar graph showing the total niobium content in weight percent of the carbonatites and fenites. 
Fig. 19: A. The concentration of $\mathrm{Ce}+\mathrm{La}+\mathrm{Nd}(w t . \%)$ as a function of $\mathrm{F}$ concentration (wt. $\%$ ) in the dolomite carbonatite. B. The concentration of $\mathrm{Ce}+\mathrm{La}+\mathrm{Nd}(w \mathrm{t} . \%$ ) as a function of $\mathrm{P}$ concentration in the dolomite carbonatite.

Fig. 20: A-C. Back-scattered electron images of dolomite carbonatite showing variations in mole fraction of iron between Dolomite 1, Dolomite 2, and Dolomite 3.

Fig. 21: The composition of Dolomite 1, Dolomite 2 and Dolomite 3 in terms of the components $\mathrm{CaO}, \mathrm{MgO}$, and $\mathrm{FeO}$ (molar proportions).

Fig. 22: The composition of mica in the dolomite carbonatite, calcite carbonatite, potassic fenite, and sodic fenite in terms of the end member components, siderophyllite, eastonite, phlogopite, and biotite after Rieder et al. (1998)................................... 89

Fig. 23: The composition of amphibole in the potassic fenite represented on the classification diagram of Hawthorne et al. (2012).

Fig. 24: The composition of pyroxene in calcite carbonatite and potassic fenite represented on the classification diagram of Morimoto et al. (1988).

Fig. 25: The composition of feldspar in sodic fenite, potassic fenite, and calcite carbonatite in terms of the components, anorthite, albite and orthoclase.

Fig. 26: A-F: Chondrite-normalized REE-profiles for the major REE-bearing minerals in the Wicheeda Carbonatite.

Fig. 27: Chondrite-normalized REE-profiles for fluorapatite samples from potassic fenite and sodic fenite 106

Fig. 28: A plot of $\delta{ }^{18} \mathrm{O}$ VSMOW versus $\delta{ }^{13} \mathrm{C}$ VPDB showing the distribution of oxygen and carbon isotopic ratios in the dolomite carbonatite (Dolomite 1, Dolomite 2, Dolomite 3 ) and calcite carbonatite. 112

Fig. 29: Results of Rayleigh-type fractaionation of the carbonatite with its exsolved fluid.

Fig. 30: Stability relationships of minerals in the system K-Na-Al-Si-OH as a function of $\log \mathrm{aK}^{+} / \mathrm{aH}^{+}$and $\log \mathrm{aNa}^{+} / \mathrm{aH}^{+}$

Fig. 31: Results of a model in which a hydrothermal fluid containing $10 \mathrm{wt} . \% \mathrm{NaCl}$ and 100 ppm Ce reacted with apatite-bearing dolomite carbonatite ( $1 \mathrm{wt} . \%$ apatite) to form monazite-(Ce) while cooling from 400 to $300{ }^{\circ} \mathrm{C}$. 125

\section{List of Tables}

Table 1: Bulk rock compositions of the Wicheeda Carbonatites and fenites .................. 47

Table 2: Structural formulae of the minerals mentioned in the text. ............................. 51

Table 3: Average composition of carbonates in the Wicheeda Carbonatite.................... 84

Table 4: Average composition of mica, amphibole and pyroxene ................................. 90

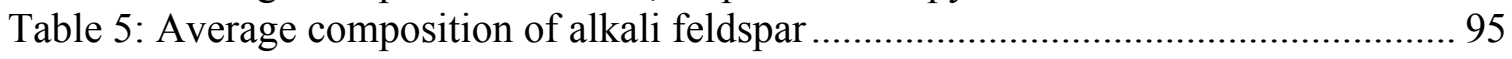

Table 6: Average composition of REE-fluorocarbonate and REE-carbonate minerals.... 98

Table 7: Average composition of fluorapatite

Table 8: Carbon and oxygen isotopic compositions of calcite carbonatite $(\mathrm{Cc})$, Dol 1, Dol

2 , and Dol 3 . 108 


\section{List of Appendices}

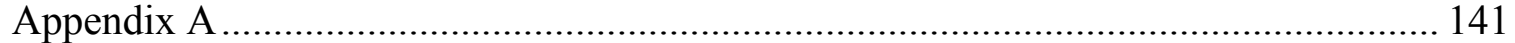

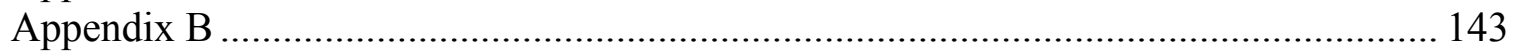

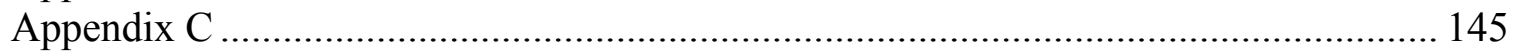

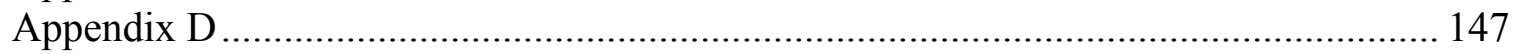

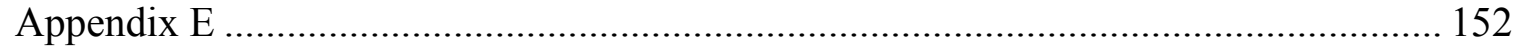

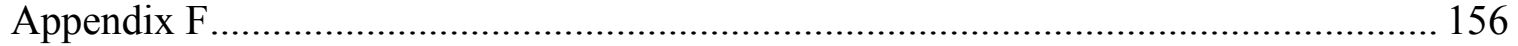

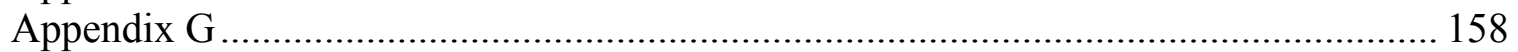

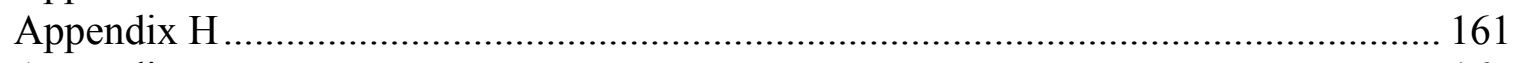

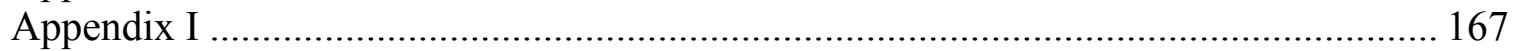

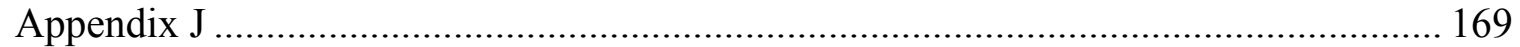

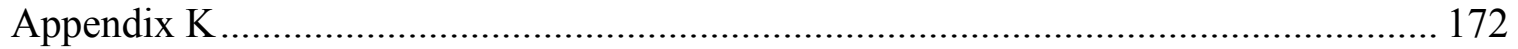


CHAPTER I: Introduction 


\section{General Statement}

\section{Introduction}

The rare earth elements (REE) are in high demand for a variety of applications in a wide range of emerging technologies, notably batteries and super magnets for use in hybrid cars, phosphors for use in lasers, LED lighting and LED and LCD flat screen televisions, and additives to improve the efficiency of solar panels. Despite their name, many of the REE have higher crustal abundances than other commonly mined metals such as Sn or Mo (Hu and Gao, 2008), however, only a small number of deposits contain mineable REE concentrations.

Throughout the early $20^{\text {th }}$ century, placer deposits in India and Brazil met the global demand for REE but by the middle of the century rapidly developing technologies increased the global demand for REE. The Steenkampskraal mine in South Africa was the dominant supplier of REE in the 1950s (Kremers, 1958), and in 1965 the carbonatitehosted Mountain Pass deposit in California began full-scale extraction of REE, primarily the light REE (LREE) before closing in 2002 (Castor and Hedrick, 2006). Since the mid 1980s, China has been the largest supplier of REE mainly from vein-hosted bastnäsite(Ce) and monazite-(Ce) in the massive Bayan Obo deposit (Chao et al., 1997). Estimated reserves at Bayan Obo exceed 80 million tons at a grade of $6 \mathrm{wt} . \%$ total rare earth oxides (TREO), making it the largest known rare earth deposit (Kynicky et al., 2012). There is additional Chinese production from the Maoniuping carbonatite deposit (1.5 million tons) and the heavy REE (HREE) ion-adsorption clay deposits of South 
China (5-10 million tons) (Kynicky et al., 2012). These deposits currently account for $90 \%$ of the world's REE production and $36 \%$ of the identified reserves (USGS, 2014). China recently reduced exports of the REE by $40 \%$ (Hatch, 2012), leading to a sharp increase in the demand for these elements. In order to meet this demand, the Mountain Pass deposit re-opened in 2012, producing LREE-enriched ore. There has also been intensive exploration outside of China leading to the discovery of many new deposits. None of these, however, has yet gone into production. In Canada, the Nechalacho (NWT) and Strange Lake (Quebec) deposits are at advanced stages of development. Among the different types of REE deposits, carbonatites are often the most LREE-enriched and represent an important exploration target as a result.

\section{Examples of Carbonatite-hosted deposits}

The Mountain Pass sövite (calcite carbonatite) and beforsite (dolomite carbonatite) host the largest and highest grade deposit in North America and only known occurrence of LREE mineralization in a carbonatite that is solely magmatic in origin. The ore body is hosted in the Sulfide Queen Carbonatite and has current reserves of approximately 18.4 million tons grading $7.98 \mathrm{wt} . \%$ REO (mainly LREE) together with minor barium (Sims and Blackman, 2012). The REE are concentrated mainly in coarse-grained bastnäsite(Ce) in the sövite and fine-grained bastnäsite-(Ce) and monazite-(Ce) in the beforsite (Castor, 2008).

The Bear Lodge (Wyoming) carbonatite-hosted REE deposit is another North American example. The REE mineralization at this deposit was the product of post-magmatic 
hydrothermal processes of calcite carbonatite and carbonatite diatreme breccias (Moore et al., 2015). The deposit has estimated reserves of 52.1 million tons of ore with an average grade of 2.71 wt.\% TREO (Moore et al., 2015; Noble et al., 2013). The REE mineralization is complex and consists of primary burbankite, which was altered by hydrothermal fluids to ancylite, barite, strontianite, and REE fluorocarbonates (Moore et al., 2015). Ancylite was later replaced by monazite-(Ce) (Moore et al., 2015).

A third North American example is the St. Honoré carbonatite REE prospect in Quebec. It measures approximately $8 \mathrm{~km}^{2}$ in plan view and comprises calcite and dolomite emplaced in alkaline syenite (Fortin-Bélanger, 1977; Fournier, 1993). The latter carbonatite was altered to ankerite carbonatite by hydrothermal fluids, which brecciated the carbonatite and precipitated bastnäsite-(Ce), parisite-(Ce), synchysite-(Ce), and monazite-(Ce). The ankerite core of the carbonatite has an average grade of 1.64 wt.\% TREO. As at Bear Lodge, the mineralization is interpreted to be a product of a postmagmatic hydrothermal fluid that precipitated the REE through a combination of decreasing temperature and increasing $\mathrm{pH}$ as a result of interaction of the ore fluid with the dolomite (Fournier, 1993; Grenier et al., 2013).

In India, the late Cretaceous to early Tertiary Amba Dongar Complex is another example of a carbonatite containing elevated REE concentrations that has been extensively altered by hydrothermal fluids. It is a carbonatite-nephelinite subvolcanic diatreme comprising a sövite ring dike that has an inner rim of carbonatite breccia surrounded by fenitized sandstone. The chronology of the Complex, including the REE mineralization, has been 
summarized by Doroshkevich et al. (2009) and comprises the intrusion of nephelinites and phonolites followed by the emplacement of the carbonatites and metasomatic alteration (fenitization) of the host rocks. This post-magmatic hydrothermal activity led to REE enrichment and fluorite mineralization. During emplacement of the sövite, exsolving aqueous fluids fractured the carbonatite and precipitated florencite, barite, strontianite, quartz, and REE-fluorocarbonates in microveinlets and vugs.

\section{The tectonic setting and origin of carbonatite magmas}

Many of the recently discovered REE deposits are hosted by carbonatite intrusions. Carbonatites are so classified on the basis of their high modal abundance of primary carbonate minerals ( $>50 \%)$ and low silica (silica-undersaturated) content $(<20 \%)$, and are subdivided into calcite- dolomite- or ankerite- carbonatites (Le Bas and Streckeisen, 1991). Their bulk lithochemistry is characterized by contain relatively little alkalis, elevated barium, and high halogen contents (mainly fluorine) and high field strength elements (HFSE) contents (Woolley and Kempe, 1989). Carbonatites commonly form in intra-continental, anorogenic extensional settings in which the thinning continental lithosphere favors decompressional melting of the mantle and emplacement of magma (Chakhmouradian and Zaitsev, 2012). The incompatible elements are initially concentrated in them due to the small degree of partial melting and the subsequent evolution of the carbonatite and/or related magmas (Hamilton et al., 1989; Meet et al., 1989; Chakhmouradian and Zaitsev, 2012). Abundant isotopic evidence suggests that the parental magmas are derived from lithospheric and asthenospheric mantle sources (Chakhmouradian and Zaitsev, 2012). The carbonatites are thought to form through 1) a 
combination of batch melting and subsequent extreme fractional crystallization of a parental silicate melt (Garson, 1965; Lee and Wyllie, 1994; Slagel 1997; Mitchell, 2005), 2) liquid immiscibility (exsolution of the carbonatite melt from the silicate melt) (Freestone and Hamilton, 1980; Kjarsgaard and Hamilton, 1988; Lee and Wyllie, 1998), or 3) directly from partial melting of carbonated mantle peridotite (von Eckermann, 1948; Eggler, 1974; Eggler, 1978; Eggler, 1989; Sweeney, 1994; Gittins and Harmer, 1997). The first two hypotheses were prompted by the common field association of carbonatites with a wide range of silicate rocks including ijolite (nepheline+augite) at Alnö, Sweden (see Kresten, 1976; Kresten et al., 1977) and Fen, Norway (see Andersen, 1984), and nepheline syenites at Khibina in the Kola alkaline province of Russia (see Zaitsev, 1998; 2014). In these examples, the carbonatites cut the earlier (deeper) silicate portions of the plutonic complex. Experimental studies have supported these hypotheses by demonstrating that batch melting and extreme fractional crystallization can produce carbonatites (Lee and Wyllie, 1994 and the existence of a miscibility gap between carbonate and silicate liquids (Brooker, 1998; Kjaarsgard, 1998; Lee and Wyllie, 1998). On the basis of carbonatite chemistry, Harmer and Gittins (1998) suggested that source magmas for carbonatites and silicates are different and the only link between them is the conduit through which they ascend. Their hypothesis is supported by neodymium and strontium isotopic compositions of African carbonatite-containing alkaline igneous suites indicating considerable differences between the carbonatites and their alkaline silicate counterparts (Harmer and Gittins, 1998). 


\section{Magmatic Concentration of REE}

Rare metal enrichment in carbonatites is attributed mainly to the unusual chemical nature of the REE. The REE typically occur in the $3+$ valence state, with the exception of Ce and $\mathrm{Eu}$, (which are sensitive to redox conditions and also occur in the 4+ and $2+$ valence states, respectively), and have atomic radii that decrease from lanthanum (La) to lutetium (Lu). As a result, the LREE have a larger ionic radius than the HREE and are more incompatible. If carbonatites form directly from small degrees of partial melting, they will therefore be preferentially enriched in the LREE. Fluorine is enriched in carbonatites for the same reason and may also form complexes with the REE, which help facilitate their enrichment. The same reasoning applies if carbonatites form from extreme fractional crystallization of nepheline syenite magmas. In this case, the incompatible elements, i.e., the LREE, are concentrated in the extremely fractionated $\mathrm{CO}_{2}$-rich residual magma. The partition coefficient of the LREE between carbonate and silicate melt is close to one but is much lower for the HREE (Veksler et al., 2012). Consequently, the liquid immiscibility hypothesis also predicts that the carbonatites will be preferentially enriched in the LREE.

Most research suggests that regardless of the manner in which they form, the REE enrichment of carbonatites is not solely due to magmatic processes but also results from post-magmatic hydrothermal processes (Morogan and Woolley, 1988; Zaitsev, 1998; Arzamastsev et al., 2001; Doroshkevich et al., 2009; Moore et al., 2015). 


\section{The Role of Hydrothermal Processes}

\section{Fenitization}

During emplacement, carbonate and silicate magmas exsolve aqueous fluids that can potentially mobilize the REE and alter the adjacent host rocks (Currie and Ferguson, 1971; Kresten 1988; Gittins et al., 1990). The latter process is called fenitization and leads to the progressive metasomatic enrichment of alkalis and desilicification of the host rock, resulting in an increasingly alkali-rich rock. The resulting mineral assemblages are dependent on the composition of the host rocks and fenitizing fluids, as well as the temperature of the fluid (Le Bas, 1981; Woolley, 1982; Rubie and Gunter, 1983; Morogan, 1994). High temperature metasomatism in the deeper parts of an intrusion typically produces sodic mineral assemblages (McKie, 1966; Vartiainen and Woolley, 1976; Le Bas, 1977; Le Bas, 2008), whereas low temperature alteration produces potassic mineral assemblages (e.g., Vartiainen and Woolley, 1976; Viladkar, 1981; Viladkar, 1986). The variation in the fenitization could also be due to the different sources of the fluids; sodic fenites have been attributed to an ijolitic (e.g., nepheline+augite) magma and potassic fenites to carbonatitic magmas (Le Bas, 1977; Morogan, 1994; Le Bas, 2008).

Brøgger (1921) first described fenites at the Fen Complex (Norway). The Complex is hosted in Proterozoic gneissic granite, which was emplaced during the early Cambrian (Verschure and Maijer, 1984) and is related to the early stages of the Oslo Rift (Griffin and Taylor, 1975). The magmatic history of the Complex is as follows: 1) emplacement of melteigite-ijolite-urtite series rocks, alkali pyroxenites, and nepheline syenites; 2) 
intrusion of coarse-grained calcite carbonatites (sövites) and silico-sövites; 3 ) intrusion of dolomite and ankerite carbonatite; and 4) intrusion of alkaline lamprophyres (Brøgger, 1921; Sæther, 1957; Barth and Ramberg, 1966; Andersen, 1984). Extensive fenitization by fluids exsolved from the ijolitic magma is interpreted to have led to the development of sodic and potassic fenites and altered the dolomite and ankerite carbonatite. During late alteration, the ankerite carbonatite was locally replaced by a hematite-calcitedolomite assemblage (rødberg) though interaction with an oxidizing fluid at temperatures $<300^{\circ} \mathrm{C}$ (Andersen 1984).

Similar fenitizing processes to those at Fen have been described at Alnö, Sweden, where pyroxenite was emplaced in Precambrian migmatitic gneisses, followed by melteigiteijolite-urtite, nepheline syenite, and finally sövite (Kresten 1979). The gneisses are composed of quartz, plagioclase, biotite, and potassium feldspar, and were altered progressively to sodic and potassic fenite. The earliest (weakest) stages of alteration resulted in the removal of quartz and breakdown of biotite to potassium feldspar and amphibole at the edges of the intrusion. Later, the rock was more intensely altered to sodic fenite as is evidenced by the complete replacement of the protolith mineralogy by albite; the latter replaced plagioclase, amphibole (e.g., arfvedsonite), and pyroxene (e.g., aegirine-augite) (Morogan and Woolley, 1988). Morogan and Woolley (1988) proposed that the fenitization was caused by an oxidizing, high temperature $\left(>500^{\circ} \mathrm{C}\right)$ fluid with high alkali, F, and $\mathrm{P}$ contents that exsolved from the carbonatite. The distribution of the fenites is interpreted to reflect a relationship in which the hottest fluids proximal to the intrusion caused albitization, and cooler fluids further from the intrusion generated a 
potassic mineral assemblage (Lagache and Weisbrod, 1977; Morogan and Woolley, 1988).

As mentioned previously, the late Cretaceous to early Tertiary Amba Dongar carbonatitealkaline Complex experienced extensive hydrothermal alteration. It is hosted in quartzite (96-98\% quartz), which makes it an ideal example to study fenitizing processes in a simple protolith. As calcite carbonatite intruded the sandstone, it exsolved two aqueous orthomagmatic fluids (Williams-Jones and Palmer, 2002). The first (deeper) fluid had a significant carbonic component and exsolved when conditions evolved to lower temperature and pressure. By contrast, the second fluid exsolved at shallower depths leading to fracturing of the host sandstone, and alteration of the quartz to potassium feldspar (Viladkar, 1981; Viladkar, 1986; Roelofsen, 1997; Williams-Jones and Palmer, 2002; Doroshkevich et al., 2009).

\section{Hydrothermal Concentration of REE}

\section{Examples of hydrothermal REE deposits}

In order to constitute a rare-metal deposit, the REE and HFSE must be concentrated in carbonatites to a greater degree than can generally occur solely by magmatic processes (Chakhmouradian and Zaitsev, 2012). Hydrothermal processes like those reported for Bear Lodge and Amba Dongar (see above) led to extensive alteration of the host carbonatite and concentration of the REE. In the case of Bear Lodge, hydrothermal fluids

characterized by high $\mathrm{F}^{-}, \mathrm{CO}_{2}$, and $\mathrm{SO}_{4}{ }^{2-}$ contents led to the replacement of primary 
burbankite by REE fluorocarbonate and REE hydrocarbonate minerals [e.g., bastnäsite(Ce), and ancylite-(Ce), respectively], and monazite-(Ce) (Moore et al., 2015).

The giant Bayan Obo Fe-Nb-REE deposit is the archetypal example of economic rare metal mineralization in rocks that have undergone intense hydrothermal alteration. It formed from intense alteration of sedimentary dolomite leading to stratified ore bodies. An overlying shale unit acted as a cap-rock as hot $\left(>400^{\circ} \mathrm{C}\right)$ acidic hydrothermal fluids dissolved the host dolomite, releasing $\mathrm{CO}_{2}$ and neutralizing the acidity of the fluid, which drove precipitation of monazite-(Ce) and bastnäsite-(Ce) and to a much lesser extent parisite-(Ce), huanghoite-(Ce) and cebaite-(Ce) as it cooled (Drew et al., 1990; Smith and Henderson, 2000; Smith and Henderson, 2000; Wu, 2007).

\section{Processes of hydrothermal REE enrichment}

The chemical behavior of the REE leading to their concentration in hydrothermal systems is reliably predicted by Pearson's rules (Pearson, 1963). According to Pearson (1963), non-polarizable cations bond preferentially with non-polarizable anions. Because the REE have a common $3+$ valence state and consequently small ionic radii, they are hard cations and should form stable aqueous complexes (in decreasing stability) with hard anions, e.g., monovalent anions in the order of $\mathrm{F}^{-}>\mathrm{OH}^{-}>\mathrm{NO}_{3}{ }^{-}>\mathrm{Cl}^{-}$(Pearson, 1963). In the case of the divalent anions, the order is $\mathrm{CO}_{3}{ }^{2-}>\mathrm{SO}_{4}{ }^{2-}>\mathrm{P}_{2} \mathrm{O}_{5}{ }^{2-}$. Experimental studies (e.g., Migdisov and Williams-Jones, 2004; 2006; 2007; Migdisov et al., 2009; Migdisov et al., 2011; Williams-Jones et al., 2012) have demonstrated that the REE form stable complexes with $\mathrm{F}^{-}$and $\mathrm{Cl}^{-}$; however, REE-fluoride minerals have very low solubility 
except under extremely acidic conditions, which precludes REE transport as fluoride complexes. Instead, the REE are most likely transported as REE-chloride complexes and F, which exists as $\mathrm{HF}$ at low $\mathrm{pH}$ conditions, acts as a depositional ligand (Williams-Jones et al., 2012). Similarly, the solubility of the REE-carbonates [e.g., ancylite-(Ce)] and REE-phosphates is also quite low suggesting that $\mathrm{CO}_{3}{ }^{2-}$ and $\mathrm{PO}_{4}{ }^{3-}$ may play an important role in the deposition of REE rather than their transport.

The deposition of REE from solution as bastnäsite- $(\mathrm{Ce})\left(\mathrm{REECO}_{3} \mathrm{~F}\right)$ can be described by the reaction:

$$
\mathrm{REECl}^{2+}+\mathrm{HF}+\mathrm{HCO}_{3}{ }^{-}=\mathrm{REECO}_{3} \mathrm{~F}+2 \mathrm{H}^{+}+\mathrm{Cl}^{-}
$$

The deposition of bastnäsite-(Ce) is dependent on $\mathrm{HCO}_{3}{ }^{-}$and $\mathrm{H}^{+}$and thus any reaction that increases the activity of $\mathrm{HCO}_{3}{ }^{-}$and $\mathrm{pH}$ will favor its precipitation (Williams-Jones et al., 2012). As proposed for Bayan Obo (dolomite), the acidic REE-bearing hydrothermal fluids are partially neutralized by interaction with the host carbonate material through the reaction:

$$
2 \mathrm{H}^{+}+\mathrm{CaMg}\left(\mathrm{CO}_{3}\right)_{2}=\mathrm{Ca}^{2+}+\mathrm{Mg}^{2+}+2 \mathrm{HCO}_{3}^{-}
$$

This leads to an increase in $\mathrm{pH}$ and $\mathrm{HCO}_{3}^{-}$activity and drives the precipitation of bastnäsite-(Ce) (Williams-Jones et al., 2012). The remobilization and precipitation of the REE as ancylite-(Ce) and fluorocarbonates in the Bear Lodge calcite carbonatite can be modeled in an identical fashion. 


\section{This study}

The purpose of the present study is to describe and understand the nature of rare earth element mineralization in the Wicheeda Carbonatite, British Columbia (Canada), a small intrusion consisting mainly of dolomite carbonatite that hosts significant REE (predominantly light REE) and $\mathrm{Nb}$ mineralization. It first garnered interest in the $1980 \mathrm{~s}$, but has been the subject of limited exploration until recently. The Wicheeda Complex is prominent on aeromagnetic maps as an ellipse that is part of a NW-trending magnetic anomaly approximately $5.5 \mathrm{~km}$ long and $2.5 \mathrm{~km}$ wide. The anomaly includes several small carbonatite plugs and dikes, and syenite dikes (e.g., Dalsin et al., 2015) in addition to the main intrusion that is the focus of this study. The carbonatites and accompanying syenites were emplaced within metasediments deposited along the ancestral margin of North America.

\section{Previous Work}

In 1961, the Geophysics Division of the Geological Survey of Canada conducted a 1:63,360 regional aeromagnetic survey across parts of British Columbia, including the Wicheeda Lake area, revealing northwest-trending linear magnetic anomalies, one of which is over the Wicheeda Carbonatite and nearby dikes. Regional mapping was conducted on the McLeod Lake (Armstrong et al., 1969) and Monkman Pass (Taylor and Stott, 1979) map sheets (Prince and George grids), both of which cover parts of the area that is the focus of the present study. The mapping revealed that the host rocks in the vicinity of the Wicheeda Carbonatite belong to the Kechika Group metasediments comprising thickly bedded, steeply dipping limestone, argillaceous limestone and weakly 
foliated grey slates (Armstrong et al., 1969; Taylor and Stott, 1979). The strata generally strike $120-140^{\circ}$ with steep dips to the NW and are in fault contact with unassigned limestone and siltstone east of the carbonatite. Adjacent to the carbonatite, they have been weakly mineralized.

Limited prospecting by Kol Lovang in the 1970s identified minor base metal showings and prompted him to stake the area. However, no follow up work was conducted and the claims were permitted to lapse. Teck Explorations Ltd. (Teck) later assayed Lovang's samples and obtained elevated niobium contents (Betmanis, 1987). This prompted the company to conduct a preliminary exploration program including geological and geophysical mapping, soil sampling, hand trenching, and stream sediment sampling. Teck staked several claims (PG 1, PG 2, Fata, Morgana, Prince, Lake, George, F, and D) and identified areas for further exploration. The Prince, George, and F grids were mapped at a line spacing of $150 \mathrm{~m}$ with soil samples collected every $50 \mathrm{~m}$. The Lake and D grids were mapped at $250 \mathrm{~m}$ and $300 \mathrm{~m}$ line spacing, respectively. Total field magnetometer readings were taken at $25 \mathrm{~m}$ intervals on the Prince, George, and Lake grids. Test pits and seven trenches totaling $79.5 \mathrm{~m}$ in length were blasted on the Prince grid. X-ray fluorescence analyses of the soil samples indicated an average of $0.23 \%$ total rare earth elements (TREE) and up to $0.24 \% \mathrm{Nb}$, whereas the George grid samples contained an average of $7.98 \%$ TREE and $0.03 \% \mathrm{Nb}$.

Limited trenching and geological mapping by the British Columbia Geological Survey (Mäder and Greenwood, 1987) revealed the presence of carbonatite exposed irregularly 
over an area with a diameter of $\sim 250 \mathrm{~m}$, containing $5 \mathrm{~cm}$ diameter rhombic ankerite phenocrysts, $2 \mathrm{~cm}$ diameter pyrite cubes together with accessory potassium feldspar, ilmenite, and a Ca-REE-fluorocarbonate mineral. Mäder and Greenwood (1987) described the argillaceous and calcareous metasedimentary rocks adjacent to the carbonatite as being "somewhat baked, but with no macroscopically visible contact metamorphic assemblages". There is no record of further exploration at Wicheeda Lake until 2008.

In 2008, Spectrum Mining Corp. began a diamond drilling exploration program on the Wicheeda Carbonatite (Lane, 2009). Four $40.7 \mathrm{~mm}$ diameter holes were drilled from one drill set-up in a fan-like pattern, with a total length of $866 \mathrm{~m}$. The drill pad was located approximately $10 \mathrm{~m}$ west of the north end of Trench GT-2 (Betmanis, 1987). The drill holes intersected dolomite carbonatite, calcite carbonatite, carbonatite breccia, and fenites. Lane (2009) noted that the intrusion is dolomitic near the surface and becomes increasingly calcite-rich with depth. The width of the carbonatite was determined to be approximately $180 \mathrm{~m}$ and $110 \mathrm{~m}$ to the northwest and northeast, respectively. Drill core logging and geochemical analyses revealed that the carbonatite is most strongly REEenriched near the surface, in the oxidized dolomite carbonatite, and is preferentially LREE-enriched with an $\mathrm{La} / \mathrm{Lu}$ ratio up to 57,348. Anomalous values of $\mathrm{Mo}, \mathrm{Ba}, \mathrm{Sr}, \mathrm{Mn}$, As, P, Y, Th were noted. Petrographic analyses of the dolomite carbonatite identified accessory potassium feldspar and albite as well as traces of niobian rutile, biotite, pyrochlore, thorite, pyrite, galena, and molybdenite (Lane, 2009). The dominant REE mineral identified was monazite-(Ce). Subordinate proportions of Ca-REE15 
fluorocarbonate interpreted to be parisite-(Ce), röntgenite-(Ce), or synchysite-(Ce) was also observed. Allanite and euxenite were identified in one sample.

In 2009, Spectrum Mining Corp. conducted additional drilling on the carbonatite including $1456 \mathrm{~mm}$ diameter diamond drill holes from three drill pads (Site A, Site B, Site C) with a total length of $1835 \mathrm{~m}$ (Lane, 2010). Site A was located approximately $100 \mathrm{~m}$ northeast of the 2008 drill site, was collared at $1100 \mathrm{~m}$ above sea level (asl) and included six drill holes (WI09-05 to WI09-10), one of which was vertical and terminated at $1044 \mathrm{~m}$ asl. The other five holes had dips ranging from 50 to 55 degrees and ended at depths ranging from 991 to $981 \mathrm{~m}$ asl. The drill holes at Site A intersected REEmineralized dolomite carbonatite and all, except WI09-10, terminated in fenite. Site B was $150 \mathrm{~m}$ northeast of the 2008 drill site and was collared at $1035 \mathrm{~m}$ asl. Four NW holes (WI09-11 to WI09-14) were drilled, including a vertical hole that reached a depth of $888 \mathrm{~m}$ asl. The three other holes had dips of 45,55 , and 60 degrees and were stopped at depths of 918, 914, and $963 \mathrm{~m}$ asl. Drill holes WI09-11 and WI09-12 ended in fenite. Drill hole WI09-14 intersected calcite carbonatite at all depths. Site C was located approximately $400 \mathrm{~m}$ northwest of the carbonatite and outside the study area. Three holes were drilled and all intersected coarse-grained calcite carbonatite but no significant REE mineralization $(<1 \%$ TREO). Assays of the main carbonatite body drilled in 2008 and 2009 averaged TREO of 1.93 wt.\%. Anthony Mariano estimated a resource of 11.3 million tons grading $1.16 \% \mathrm{Ce}+\mathrm{La}+\mathrm{Nd}$, mainly concentrated in coarse-grained bastnäsite-(Ce) and monazite-(Ce) (Lane, 2010). 
In July 2010, Canadian International Minerals Inc. (CIN) conducted a 566.1 line-km helicopter-borne aeroTEM system electromagnetic, magnetic, and radiometric survey of the Wicheeda Carbonatite and former Prince grid claims (presently owned by Commerce Resources). Magnetic and radiometric anomalies were noted southeast of Wicheeda Lake, including a small $(<150 \mathrm{nT})$ ellipsoidal anomaly at the Wicheeda Carbonatite and linear anomalies on the CIN properties southeast of the intrusion (Bruland, 2011). Diamond drilling on the CIN properties revealed a series of carbonatite dikes and veins, and mafic dikes (Bruland, 2011; Dalsin and Groat, 2011). The highest-grade REE intersection was encountered in a carbonatite dike averaging 4.68 wt.\% TREO over 0.9 $\mathrm{m}$.

The REE mineralogy, geochemistry and geochronology of the carbonatite dikes and veins on the properties southeast of the Wicheeda Carbonatite have been the subject of a detailed study by Dalsin et al. (2015). They interpreted the REE mineralization, which is hosted in calcite, ankerite and dolomite carbonatite, to be magmatic and the product of late-stage crystallization during rapid cooling. The major REE minerals identified are Ca-REE-fluorocarbonates, Ba-REE-fluorocarbonates, ancylite-(Ce), monazite-(Ce), allanite-(Ce), and euxenite-(Y). The Ca-REE-fluorocarbonate mineralization is described as comprising fine-grained subhedral crystals with syntaxial intergrowths of bastnäsite(Ce) and parisite-(Ce). The Ba-REE-fluorocarbonates are described as "very fine-grained crystals of varying morphologies $[\ldots]$ subject to rimming and infilling by fine-grained parisite-(Ce), synchysite-(Ce), and monazite-(Ce)" (Dalsin et al., 2015) and are interpreted to be magmatic. The synchysite-(Ce), which occurs as fine-grained masses 
forming around the Ba-REE-fluorocarbonates and as fracture infill was also interpreted to be magmatic. Accessory apatite, ilmenite, thorite, fluorite, pyrochlore, and various sulfides were identified.

\section{Objectives and Methodology}

The objective of this thesis is to determine the nature and origin of REE, Nb, and Th mineralization in the Wicheeda Carbonatite and the adjacent Kechika Group metasedimentary rocks.

The research objectives were achieved through:

1. Field work at the Wicheeda Carbonatite, including mapping, outcrop description, drill core logging, and sampling of rocks for petrographic and geochemical analyses.

2. Preparing a detailed geological map of the deposit to determine its nature and that of the adjacent Kechika Group metasedimentary rocks, and their relationships to major structural features in the field area.

3. Optical petrographic examination of polished thin sections to identify the main rock-forming and ore minerals, evaluate their modal abundances, determine their textural relationships, and place them in an overall paragenetic sequence.

4. Compilation and analysis of bulk rock geochemical data acquired by Spectrum Mining Corp.

5. Energy dispersive scanning electron microscopy (SEM) and quantitative electron microprobe analyses to identify and determine the chemical composition of rock forming, ore, and alteration minerals. These data confirmed the optical 
identification of the minerals, assisted in evaluating textural relationships and helped determine the paragenetic sequence. SEM and microprobe analyses were conducted using a JEOL JXA-8900L electron microprobe equipped with five wavelength-dispersive $\mathrm{X}$-ray spectrometers and a $\mathrm{Si}(\mathrm{Li})$ energy-dispersive $\mathrm{X}$-ray detector at McGill University. Spot analyses using wavelength-dispersive spectrometry were conducted at a voltage of $15 \mathrm{kV}$ and a $30 \mathrm{nA}$ beam current together with a $10 \mu \mathrm{m}$ beam diameter for pyroxene and a $5 \mu \mathrm{m}$ beam diameter for apatite. A 20nA beam current and a $5 \mu \mathrm{m}$ beam diameter was used for amphibole and mica, and a $10 \mu \mathrm{m}$ beam size was used for feldspar. Dolomite was analyzed using a $20 \mathrm{nA}$ beam current and a $20 \mu \mathrm{m}$ beam diameter. The REE minerals were analyzed using a $20 \mathrm{nA}$ beam current and a $10 \mu \mathrm{m}$ beam diameter.

6. Stable isotope analyses of carbon and oxygen to determine the ratios of these elements in calcite carbonatite and dolomite carbonatite. Measurement of ${ }^{13} \mathrm{C}$ and ${ }^{18} \mathrm{O}$ isotopes were conducted using a $\mathrm{Nu}$ Instruments large-radius mass spectrometer at McGill University. All samples were ground using a drill press. Carbon dioxide was released from reaction with phosphoric acid and transferred cryogenically to a dual micro inlet followed by isotopic measurement. The $\delta{ }^{13} \mathrm{C}$ data was standardized to Vienna Pee Dee Belemnite (V-PDB) and the $\delta{ }^{18} \mathrm{O}$ data to Vienna Standard Mean Ocean Water (V-SMOW).

7. Modeling of the calcite and dolomite carbonatite isotope data using the multicomponent Rayleigh isotopic fractionation model of Ray and Ramesh (2000) to estimate the initial $\delta{ }^{13} \mathrm{C}$ and $\delta{ }^{18} \mathrm{O}$ isotopic compositions of the carbonatites, 
and determine whether the carbon isotopic compositions evolved independently from the oxygen isotopic compositions.

8. Thermodynamic modeling of the fluid-rock interactions leading to the concentration of the REE in minerals such as monazite-(Ce) using Hch equilibrium modeling software. Aliquots of REE-bearing fluid (mainly Ce) were reacted with a phosphate-bearing carbonatite, depositing monazite-(Ce). The $\mathrm{NaCl}$ content of the fluid was assumed to be 10 wt. $\% \mathrm{NaCl}$ and the $\mathrm{pH} 2.5$. Thermodynamic data for monazite-(Ce) were taken from Popa et al. (2007) and for the aqueous REE species from Migdisov et al. (2009). The fluid was assumed to cool from $400^{\circ} \mathrm{C}$ to $300^{\circ} \mathrm{C}$.

\section{Thesis organization}

This thesis has been written in manuscript format. In addition to the manuscript, there are two supporting chapters and eleven appendices (A-K). An introductory chapter, including a literature review and description of the research objectives and methodology, explains the motivation of the research. The second chapter is a journal manuscript entitled "The nature and origin of the REE mineralization in the Wicheeda Carbonatite, British Columbia, Canada" and is co-authored by Joel Trofanenko, Anthony E. WilliamsJones, and George J. Simandl. The manuscript describes the geology and mineralogy of the Wicheeda Carbonatite and fenite, and presents whole rock chemical data, mineral chemical data and whole rock carbon and oxygen isotopic data. The information is used to develop a model for the formation of the intrusion and the processes responsible for mineralization. Chapter 3 summarizes the conclusions of the study, identifies the 
contributions to knowledge, and makes recommendations for future work. The appendices comprise: A. Locations of outcrops sampled; B. Locations of drill cores sampled; C. Counting times and standards used for each element analyzed with the electron microprobe; D. Results of electron microprobe analyses of dolomite; E. Results of electron microprobe analyses of biotite and biotite; F. Results of electron microprobe analyses of amphibole; G. Results of electron microprobe analyses of pyroxene; $\mathrm{H}$. Results of electron microprobe analyses of albite and potassium feldspar; I. Results of electron microprobe analyses of apatite; J. Results of electron microprobe analyses of bastnäsite-(Ce), parisite-(Ce), synchysite-(Ce), cordylite-(Ce), and ancylite-(Ce); K. Results of electron microprobe analyses of monazite. 


\section{References}

Andersen, T., 1984, Secondary processes in carbonatites - petrology of rodberg (hematite-calcite-dolomite carbonatite) in the Fen Central Complex, Telemark (South-Norway): Lithos, v. 17, p. 227-245.

Armstrong, J. E., Hoadley, J. W., Muller, J. E., and Tipper, H. W., 1969, Geology, McLeod Lake Map Area (93J), Geological Survey of Canada, p. Map 1204A.

Arzamastsev, A. A., Bea, F., Glaznev, V. N., Arzamastseva, L. V., and Montero, P., 2001, The Kola alkaline province in the Paleozoic: Evaluation of primary mantle magma composition and magma generation conditions: Russian Journal of Earth Sciences, v. 3, p. 1-32.

Barth, T. F. W., and Ramberg, I. B., 1966, The Fen circular complex: New York, NY, Interscience.

Betmanis, A. I., 1987, Report on geological, geochemical and magnetometer surveys on the Prince and George groups, cariboo mining division, in British Columbia Ministry of Energy, Mines, and Petroleum Resources, p. 1-86.

Brøgger, W. C., 1921, Die Eruptivgesteine des Kristianiagebietes. IV: Das fengebiet in Telemark, Norwegen: Vit. Seslk. Skr. I Mat. Nat. Klasse, v. 1.

Brooker, R. A., 1998, The effect of $\mathrm{CO}_{2}$ saturation on immiscibility between silicate and carbonate liquids: an experimental study: Journal of Petrology, v. 39, p. 19051915.

Bruland, T., 2011, 2010 Diamond drilling on Carbo rare earth element property, p. 5-31.

Castor, S. B., 2008, The Mountain Pass rare-earth carbonatite and associated ultrapotassic rocks, California: Canadian Mineralogist, v. 46, p. 779-806.

Castor, S. B., and Hedrick, J. B., 2006, Rare earth elements, Society for Mining, Metallurgy and Exploration.

Chakhmouradian, A. R., and Zaitsev, A. N., 2012, Rare earth mineralization in igneous rocks: sources and processes, Elements, 8, p. 347-353.

Chao, E. C. T., Back, J. M., Minkin, J. A., Tatsumoto, M., Junwen, W., Conrad, J. E., and Mckee, E. H., 1997, The sedimentary Carbonate-Hosted Giant Bayan Obo REEFe-Nb Ore Deposit of Inner Mongolia, China: A Cornerstone Example for Giant Polymetallic Ore Deposits of Hydrothermal Origin: US Geological Survey Bulletin 2143. 
Currie, K. L., and Ferguson, J., 1971, A study of fenitization around the alkaline carbonatite complex at Callander Bay, Ontario, Canada: Canadian Journal of Earth Sciences, v. 8, p. 498-517.

Dalsin, M. L., and Groat, L. A., 2011, The Geology and Mineralogy of the Carbo Property, Wicheeda Carbonatite Complex, BC, Roundup 2011: Vancouver, BC.

Dalsin, M. L., Groat, L. A., Creighton, S., and Evans, R. J., 2015, The mineralogy and geochemistry of the Wicheeda Carbonatite Complex, British Columbia Canada: Ore Geology Reviews, v. 64, p. 523-542.

Doroshkevich, A. G., Viladkar, S. G., Ripp, G. S., and Burtseva, M. V., 2009, Hydrothermal REE mineralization in the Amba Dongar carbonatite complex, Gujarat, India: The Canadian Mineralogist, v. 47, p. 1105-1116.

Drew, L. J., Qingrun, M., and Weijun, S., 1990, The Bayan Obo iron rare-earth niobium deposits, Inner Mongolia, China: Lithos, v. 26, p. 43-65.

Eggler, D. H., 1974, Effect of CO2 on the melting of peridotite: Carnegie Institution of Washington Yearbook, v. 73, p. 215-224.

Eggler, D. H., 1978, The effect of $\mathrm{CO} 2$ upon partial melting of peridotite in the system $\mathrm{Na}_{2} \mathrm{O}-\mathrm{CaO}-\mathrm{Al}_{2} \mathrm{O}_{3}-\mathrm{MgO}-\mathrm{SiO}_{2}-\mathrm{CO}_{2}$ to $35 \mathrm{~kb}$, with an analysis of melting in a peridotite- $\mathrm{H}_{2} \mathrm{O}-\mathrm{CO}_{2}$ system: American Journal of Science, v. 278, p. 305-343.

Eggler, D. H., 1989, Carbonatites, primary melts, and mantle dynamics, in Bell, K., ed., Carbonatites, Genesis and Evolution: London, UK, Unwin Hyman Ltd., p. 561579 .

Fortin-Bélanger, M., 1977, Le complexe annulaire, à carbonatite de St.-Honoré (P.Q., Canada) et sa minéralisation à niobium: étude pétrographique et géochimique, Université Claude Bernard, 308 p.

Fournier, A., 1993, Magmatic and hydrothermal controls of LREE mineralization of the St. Honoré carbonatite, Quebec: Unpub. Manuscript thesis, McGill University, $147 \mathrm{p}$.

Freestone, I. C., and Hamilton, D. L., 1980, The role of liquid immiscibility in the genesis of carbonatites - an experimental study: Contributions to Mineralogy and Petrology, v. 73, p. 105-117.

Garson, M. S., 1965, Carbonatites in Southern Malawi: Geological Survey Department Bulletin, v. 15, p. 128. 
Gittins, J., Beckett, M. F., and Jago, B. C., 1990, Composition of the fluid phase accompanying carbonatite magma: a critical examination: American Mineralogist, v. 75 , p. 1106-1109.

Gittins, J., and Harmer, R. E., 1997, What is ferrocarbonatite? A revised classification: Journal of African Earth Sciences, v. 25, p. 159-168.

Grenier, L., Tremblay, J.-F., and Sirois, R., 2013, NI 43-101 Technical report, surface diamond drilling exploration program for rare earth elements, IAMGOLD Corporation, p. 161.

Griffin, W. L., and Taylor, P. N., 1975, The Fen Damkjernite: Petrology of a "centralcomplex kimberlite": Physics and Chemistry of the Earth, v. 9, p. 163-177.

Hamilton, D. L., Bedson, P., and Esson, J., 1989, The behaviour of trace elements in the evolution of carbonatites, in Bell, K., ed., Carbonatites, Genesis and Evolution: London, UK, Unwin Hyman Ltd.

Harmer, R. E., and Gittins, J., 1998, The case for primary, mantle-derived carbonatite magma: Journal of Petrology, v. 39, p. 1895-1903.

Hatch, G. P., 2012, Dynamics in the global market for rare earths, Elements, 8, Mineralogical Society of America, p. 341-346.

Hu, Z. G., S., 2008, Upper crustal abundances of trace elements: A revision and update: Chemical Geology, v. 253, p. 205-221.

Kjarsgaard, B. A., 1998, Phase relations of a carbonated high-CaO nephelinite at 0.2 and 0.5 GPa: Journal of Petrology, v. 39, p. 2061-2075.

Kjarsgaard, B. A., and Hamilton, 1988, Liquid immiscibility and the origin of alkali-poor carbonatites: Mineralogical Magazine, v. 52, p. 43-55.

Kremers, H. E., 1958, Rare earths: Engineering and Mining Journal, v. 159, p. 145-146.

Kresten, P., 1976, A magmatic survey of the Alno Complex: Geologiska Foreningens I Stockholm Forhandlingar, v. 98, p. 361-362.

Kresten, P., 1979, The Alnö complex: discussion of the main features, bibliography and excursion guide, Nordic Carbonatite Symposium, p. 67.

Kresten, P., 1988, The chemistry of fenitization: examples from Fen, Norway: Chemical Geology, v. 68, p. 329-349. 
Kresten, P., Printzlau, I., Rex, D. C., Vartiainen, H., and Woolley, A. R., 1977, New ages of carbonatitic and alkaline ultramafic rocks from Sweden and Finland: Geologiska Foreningens I Stockholm Forhandlingar, v. 99, p. 62-65.

Kynicky, J., Smith, M. P., and Xu, C., 2012, Diversity of rare earth deposits: The key example of China, Elements, 8, p. 361-367.

Lagache, M., and A. Weisbrod, 1977, The system: two alkali feldspars-KCl-NaCl-H2O at moderate to high temperatures and low pressures: Contributions to Mineralogy and Petrology, v. 62, p. 77-101.

Lane, R., 2009, Diamond drilling report on the Wicheeda property, p. 1-196.

Lane, R., 2010, 2009 Diamond drilling report on the Wicheeda rare earth property, p. 129.

Le Bas, M. J., 1977, Carbonatite-Nephelinite Volcanism: London, Wiley.

Le Bas, M. J., 1981, Carbonatite magmas: Mineralogical Magazine, v. 44, p. 133-140.

Le Bas, M.J., 2008, Fenite associated with carbonatites: Canadian Mineralogist, v. 46, p. 915-932.

Lee, W.-J., and Wyllie, P. J., 1994, Experimental data bearing on liquid immiscibility, crystal fractionation, and the origin of calciocarbonatites and natrocarbonatites: International Geology Reviews, v. 36, p. 797-819.

Lee, W.-J., and Wyllie, P. J., 1998, Processes of crustal carbonatite formation by liquid immiscibility and differentiation, elucidated by model systems: Journal of Petrology, v. 39, p. 2005-2013.

Mäder, U. K., and Greenwood, H. J., 1987, Carbonatites and related rocks of the Prince and George claims, northern rocky mountains (93I; 93J), Geological Fieldwork 1987, British Columbia Ministry of Energy, Mines and Petroleum Resources.

McKie, D., 1966, Fenitization, in Tuttle, O. F. G., J., ed., Carbonatites: New York, NY, Interscience, p. 261-294.

Meen, J. K., Ayers, J. C., and Fregeau, E. J., 1989, A model of upper mantle metasomatism by carbonated alkaline melts: trace element and isotopic compositions of mantle source regions of carbonatite and other continental igneous rocks, in Bell, K., ed., Carbonatites, Genesis and Evolution: London, UK, Unwin Hyman Ltd., p. 464-495. 
Migdisov, A., and Williams-Jones, A. E., 2004, A spectrophotometric study of Palladium (II) complexation in chloride solutions: Geochimica et Cosmochimica Acta, v. 68, p. A289.

Migdisov, A., and Williams-Jones, A. E., 2006, An experimental study of solubility and speciation of NdF3 in F-bearing aqueous solutions: Geochimica et Cosmochimica Acta, v. 70, p. A419.

Migdisov, A., and Williams-Jones, A. E., 2007, An experimental study of the solubility and speciation of neodymium (III) fluoride in F-bearing aqueous solutions: Geochimica et Cosmochimica Acta, v. 71, p. 3056-3069.

Migdisov, A., Williams-Jones, A. E., van Hinsberg, V., and Salvi, S., 2011, An experimental study of the solubility of baddeleyite $\left(\mathrm{ZrO}_{2}\right)$ in fluoride-bearing solutions at elevated temperature: Geochimica et Cosmochimica Acta, v. 75, p. 7426-7434.

Migdisov, A., Williams-Jones, A. E., and Wagner, T., 2009, An experimental study of the solubility and speciation of the Rare Earth Elements (III) in fluoride- and chloride-bearing aqueous solutions at temperatures up to 300 degrees $\mathrm{C}$ : Geochimica et Cosmochimica Acta, v. 73, p. 7087-7109.

Mitchell, R. H., 2005, Carbonatites and carbonatites and carbonatites: Canadian Mineralogist, v. 43, p. 2049-2068.

Sims, J., and Blackman, B., 2012, Molycorp's Rare Earth Reserves at Mountain Pass Increase by 36\%, Molycorp. Accessed 25 November 2014. http://www.molycorp.com/molycorps-rare-earth-reserves-at-mountain-passincrease-by-36/

Moore, M., Chakhmouradian, A. R., Mariano, A. N., and Sidhu, R., 2015, Evolution of rare-earth mineralization in the Bear Lodge carbonatite, Wyoming: Mineralogical and isotopic evidence: Ore Geology Reviews, v. 64, 499-521.

Morogan, V., 1994, Ijolite versus carbonatite as sources of fenitization: Terra Nova, v. 6, p. 166-176.

Morogan, V., and A.R. Woolley, 1988, Fenitization at the Alno carbonatite complex, Sweden; distribution, mineralogy and genesis: Contributions to Mineralogy and Petrology, v. 100, p. 169-182.

Noble, A. C., Pickarts, J. T., and Larsen, R. K., 2013, Technical report on the mineral reserves and resources and development of the Bull Hill Mine, Rare Element Resources, p. 1-207. 
Pearson, R. G., 1963, Hard and soft acids and bases: Journal of the American Chemical Society, v. 85, p. 3533-3539.

Popa, K., Konings, R. J. M., and Geisler, T., 2007, High-temperature calorimetry of (La $\mathrm{La}_{1-}$ $\left.{ }_{x} \mathrm{Ln}_{\mathrm{x}}\right) \mathrm{PO}_{4}$ solid solutions: Journal of Chemical Thermodynamics, v. 39, p. 236239.

Ray, J. S., and Ramesh, R., 2000, Rayleigh fractionation of stable isotopes from a multicomponent source: Geochimica et Cosmochimica Acta, v. 64, p. 299-306.

Roelofsen, J. N., 1997, The primary and secondary mafic silicates of two alkaline anorogenic complexes: Strange Lake (Quebec-Labrador) and Amba Dongar (Gujarat, India), McGill University, 321 p.

Rubie, D. C., and Gunter, W. D., 1983, The role of speciation in alkaline igneous fluids during fenite metasomatism: contributions to mineralogy and petrology, v. 82, p. 165-175.

Sæther, E., 1957, The alkaline rock province of the Fen area in southern Norway: Det Klonglige Norske Videnskabsselskaps Skrifter, v. 1, p. 150.

Slagel, M., 1997, Miscible silicate-carbonate liquids in the system $\mathrm{K}_{2} \mathrm{O}-\mathrm{CaO}-\mathrm{MgO}-$ $\mathrm{Al}_{2} \mathrm{O}_{3}-\mathrm{SiO}_{2}-\mathrm{H}_{2} \mathrm{O}-\mathrm{CO}_{2}$, Geological Association of Canada-Mineralogical Association of Canada Ottawa '97, p. A-139.

Smith, M. P., and Henderson, P., 2000, Preliminary fluid inclusion constraints on fluid evolution in the Bayan Obo Fe-REE-Nb deposit, inner Mongolia, China: Economic Geology, v. 95, p. 1371-1388.

Sweeney, R. J., 1994, Carbonatite melt compositions in the earth's mantle: Earth and Planetary Science Letters, v. 128, p. 259-270.

Taylor, G. C., and Stott, D. F., 1979, Geology, Monkman Pass Map Area, British Columbia (93I), Geological Survey of Canada, p. Open File Map 630.

USGS, 2014, Mineral commodity summaries 2014, U.S. Geological Survey, p. 131-132.

Vartiainen, H., and Woolley, A. R., 1976, The petrography, mineralogy, and chemistry of the fenites of the Sökli carbonatite intrusion, Finland: Geological Survey of Finland Bulletin, v. 280.

Veksler, I. V., Dorfman, A. M., Dulski, P., Kamenetsky, V. S., Danyushevsky, L., Jeffries, T., and Dingwell, D. B., 2012, Partitioning of elements between silicate melt and miscible fluoride, chloride, carbonate, phosphate, and sulfate melts, with 
implications to the origin of natro-carbonatite: Geochimica et Cosmochimica Acta, v. 79 , p. $20-40$.

Verschure, R. H., and Maijer, C., 1984, Pluri-metasomatic resetting of Rb-Sr whole-rock systems around the Fen peralkaline-carbonatitic ring complex, Telemark, south Norway: Terra Cognita, v. 4, p. 191-192.

Viladkar, S. G., 1981, The carbonatites of Amba Dongar, Gujarat, India: Geological Society of Finland Bulletin, v. 53, p. 17-28.

Viladkar, S. G., 1986, Fenitization at the Amba Dongar carbonatite-alkalic complex, India: Proceedings NEMIRAM (New Minerals and Raw Materials) Symposium, Czechoslovakia, 1986, p. 170-189.

von Eckermann, H., 1948, The alkaline district of Alnö island: Sveriges Geologiska Undersökning, v. 36, p. 1-176.

Williams-Jones, A. E., Migdisov, A. A., and Samson, I. M., 2012, Hydrothermal Mobilisation of the Rare Earth Elements - a Tale of "Ceria" and "Yttria", Elements, p. 26.

Williams-Jones, A. E., and Palmer, D. A. S., 2002, Fluid evolution of the Amba Dongar carbonatite complex, India: Chemical Geology, v. 185, p. 283-301.

Woolley, A. R., 1982, A discussion of carbonatite evolution and nomenclature, and the generation of sodic and potassic fenites: Mineralogical Magazine, v. 46, p. 13-17.

Woolley, A. R., and Kempe, D. R. C., 1989, Carbonatites: nomenclature, average chemical compositions, and element distribution, in Bell, K., ed., Carbonatites, Genesis and Evolution: London, UK, Unwin Hyman Ltd., p. 1-13.

Wu, C., 2007, Bayan Obo controversy: carbonatites versus Iron Oxide-Cu-Au-(REE-U): Resource Geology, v. 58, p. 348-354.

Wyllie, P. J., and Tuttle, O. F., 1960, The system $\mathrm{CaO}-\mathrm{CO}_{2}-\mathrm{H}_{2} \mathrm{O}$ and the origin of carbonatites: Journal of Petrology, v. 1, p. 1-46.

Zaitsev, A. N., Wall, F., and Le Bas, M. J., 1998, REE-Sr-Ba minerals from the Khibina carbonatites, Kola peninsula, Russia: their mineralogy, paragenesis and evolution: Mineralogical Magazine, v. 62, p. 225-250.

Zaitsev, A. N., Williams, C. T., Jeffries, T. E., Strekopytov, S., Moutte, J., Ivashchenkova, O. V., Spratt, J., Petrov, S. V., Wall, F., Seltmann, R., and Borozdin, A. P., 2014, Rare earth elements in phoscorites and carbonatites of the 
Devonian Kola Alkaline Province, Russia: Examples from Kovdor, Khibina, Vuoriyarvi and Turiy Mys complexes: Ore Geology Reviews, v. 61, p. 204-225. 


\title{
CHAPTER II: Journal Manuscript
}

The nature and origin of the REE mineralization in the Wicheeda Carbonatite, British Columbia, Canada

Joel Trofanenko, Anthony E. Williams-Jones, and George J. Simandl

\author{
Joel Trofanenko and Anthony E. Williams-Jones \\ Earth and Planetary Sciences, McGill University \\ 3450 University Street, Montreal, QC \\ Canada H3A 0E8
}

\author{
George J. Simandl \\ British Columbia Geological Survey \\ Ministry of Energy and Mines, Victoria, BC \\ Canada V8W 9N3
}

To be submitted to: Economic Geology 


\begin{abstract}
The Wicheeda Carbonatite is a small plug that hosts relatively high-grade LREE mineralization in the British Columbia alkaline province. It was emplaced within metasedimentary rocks belonging to the Kechika Group, which have been altered to potassic fenite near the intrusion and sodic fenite at greater distances from it. The intrusion comprises a ferroan dolomite carbonatite core, which passes outwards gradationally into calcite carbonatite. The potentially economic REE mineralization is hosted by the dolomite carbonatite. Three types of dolomite have been recognized. Dolomite 1 constitutes the bulk of the dolomite carbonatite, Dolomite 2 replaced Dolomite 1 near veins and vugs and Dolomite 3 occurs in veins in and vugs together with the REE mineralization. Carbon and oxygen isotope ratios indicate that the calcite carbonatite crystallized from a magma of mantle origin, that Dolomite 1 is of primary igneous origin, that Dolomite 2 has a largely igneous signature with a small hydrothermal input and that Dolomite 3 is of hydrothermal origin. The REE minerals comprise REEfluorocarbonates, ancylite-(Ce), and monazite-(Ce) and in addition to Dolomite 3, also occur with barite, molybdenite, pyrite and thorite. Minor concentrations of niobium are present as magmatic pyrochlore in the calcite carbonatite.
\end{abstract}

A model is proposed in which calcite carbonatite was the earliest phase to crystallize and followed by dolomite carbonatite. During crystallization of the latter, an aqueouscarbonic fluid was exsolved, which mobilized the REE as chloride complexes into vugs and fractures in the dolomite carbonatite, where they precipitated, largely in response to the increase in $\mathrm{pH}$ that accompanied fluid-rock interaction. These fluids altered the host 
metasedimentary rock to potassic fenite adjacent to the carbonatite and distal to it, they mixed with formational waters to produce sodic fenite. 


\section{Introduction}

It has been long known that carbonatites are enriched in the rare earth elements (REE), and in some cases host economic or potentially economic concentrations of these metals. Examples of the latter include Mountain Pass (Castor, 2008), Maoniuping (Xu, 2003; 2004; Kynicky et al., 2012), Kangankunde (Wall and Mariano, 1996), St. Honoré (FortinBélanger, 1977; Fournier, 1993), Amba Dongar (Doroshkevich et al., 2009), and Bear Lodge (Moore et al., 2015). In rare cases, such as the Mountain Pass deposit, textural relationships indicate that the REE mineralization is magmatic in origin (Castor, 2008), but more commonly the available evidence suggests that it was the product of both magmatic and hydrothermal processes (e.g., Amba Dongar, Doroshkevich et al., 2009; Bear Lodge, Moore et al., 2015). In the latter deposits, the carbonatites were strongly overprinted by hydrothermal fluids resulting in remobilization and precipitation of the REE in vug- and vein-hosted assemblages. Although it is widely believed that these fluids originate from the carbonatite (Currie and Ferguson, 1971; Kresten 1988; Wyllie, 1989; Gittins et al., 1990) and fluid inclusion studies (e.g., Bühn and Rankin, 1999; Bühn et al., 2002; Williams-Jones and Palmer, 2002) have documented the nature of the fluids exsolving from carbonatites, the controls on the REE mineralization are poorly understood. In many carbonatite-hosted deposits, there is a close association of the REE mineralization with fluorite (e.g., Amba Dongar, Doroshkevich et al., 2009; Bear Lodge, Moore et al., 2015), and this has led some authors (Möller et al., 1980; Salvi and Williams-Jones, 1990; Williams-Jones et al., 2000) to suggest that the REE are transported as fluoride complexes, particularly as such complexes are known to be extremely stable (Migdisov et al., 2009). However, recent modeling has shown that 
transport of REE as fluoride complexes is not feasible because of the low activity of fluoride ions at low $\mathrm{pH}$ due to their association in the weak acid, HF, and the very low solubility of REE minerals at higher $\mathrm{pH}$ (Williams-Jones et al., 2012). This modeling showed that REE-chloride complexes might be a plausible alternative transport medium for systems in which chlorinity is high, and that for such systems increasing $\mathrm{pH}$ and/or decreasing temperature could lead to REE mineralization. They also noted that the REE form strong complexes with sulphate ions and that such complexation could be another means of REE transport. Fluid inclusion studies of the Amba Dongar carbonatite show that fluids exsolving from carbonatites (aqueous-carbonic) can have high concentrations of both chloride and sulphate ions (Williams-Jones and Palmer, 2002). The fluids in this case were responsible for fenitization and likely also produced the REE mineralization, i.e., REE-fluorocarbonates that are associated with barite, fluorite, and quartz (Doroshkevich et al., 2009). For Bear Lodge, it has been proposed that the REE were concentrated as magmatic burbankite, and remobilized by carbo-hydrothermal fluids enriched in $\mathrm{F}^{-}, \mathrm{CO}_{2}^{-}$, and $\mathrm{SO}_{4}{ }^{2-}$, which deposited ancylite-(Ce), REE-fluorocarbonates, and monazite-(Ce) (Moore et al., 2015).

The Wicheeda Carbonatite, which is located in the Alkaline Igneous Province of British Columbia, Canada (Fig. 1) and is the subject of this paper, contains potentially exploitable concentrations of the REE (Pell, 1994; Lane, 2009; 2010). Like many intrusions in this Province (Pell, 1994), the Wicheeda Carbonatite has an extensive fenitization halo. Moreover, a preliminary study suggests that the REE mineralization may be hydrothermal in origin (Lane, 2009). The Wicheeda Carbonatite therefore 
presents an excellent opportunity to better understand the controls on hydrothermal carbonatite-hosted REE mineralization. The intrusion (Fig. 1) was first described in British Columbia Geological Survey reports (Mäder and Greenwood, 1987; Pell, 1994) and explored by Teck Explorations Ltd. over 20 years ago (Betmanis, 1987), but received little attention until 2008, when Spectrum Mining Corp explored it by a variety of methods, including drilling. They reported that the carbonatite contains a resource of 11.3 million tons grading 1.95 wt.\% TREO (Lane, 2010), making it the best prospect for an economic REE deposit in British Columbia (Pell, 1994; Lane, 2009, 2010). The REE mineralization is concentrated mainly in the carbonatite, largely as carbonate minerals, although it is also observed locally in the fenite. Carbonatite also occurs to the southeast of the main intrusion, as dikes and sills associated with alkaline igneous intrusions. Canadian International Minerals Inc. explored these bodies and reported the occurrence in them of sporadic carbonatite-hosted REE mineralization. 


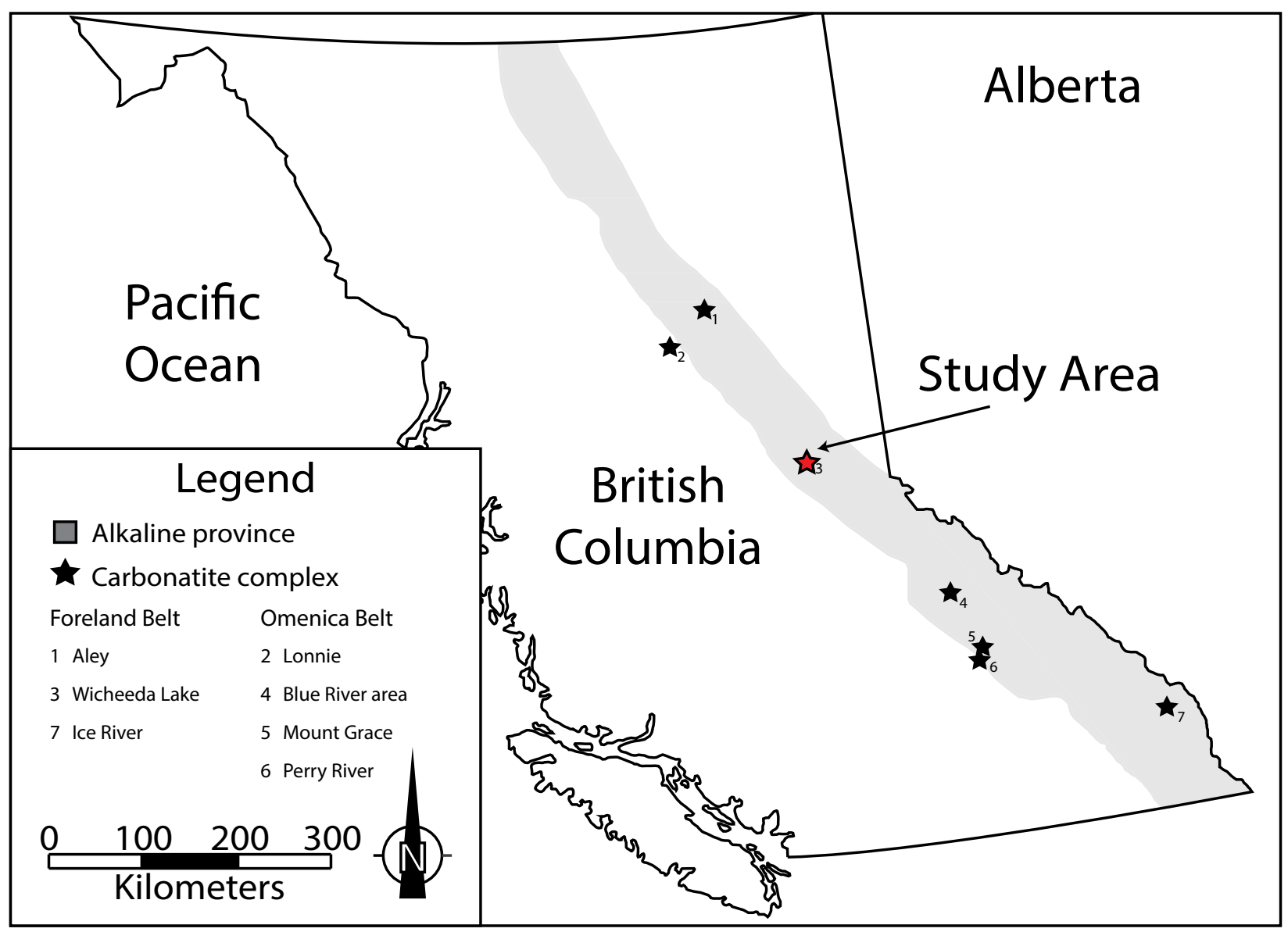

Fig. 1: A map of British Columbia showing the location of the British Columbia alkaline province and the most important rare-metal deposits. 
In this paper, we use a combination of field and laboratory techniques to investigate the nature and genesis of the REE mineralization in the main Wicheeda Carbonatite. The scope of work included field mapping, outcrop description, drill core logging and sampling of the representative lithologies, optical and scanning electron microscopy, chemical analyses (including isotopic) of the bulk rock and minerals, and thermodynamic modeling. The results show that the REE mineralization is hydrothermal in origin. We have developed a model in which the REE were concentrated in fluids released from the carbonatite magma and precipitated REE carbonates in response to decreasing temperature and the increase in $\mathrm{pH}$ that accompanied interaction of the fluids with the crystallized carbonatite.

\section{Geological Setting}

The Wicheeda Carbonatite was emplaced in the Kechika Group metasedimentary rocks of the Foreland belt of the Canadian Cordillera, an imbricated fold and thrust assemblage of passive margin strata deposited along the ancestral margin of North America. The Foreland Belt contains a large alkaline province (Fig. 1), which stretches from the Canadian Cordillera to the southwestern United States (Millonig et al., 2012). It hosts the Aley, Ice River, Bear Paw, Rock Canyon, Frenchman Cap Dome, and Wicheeda alkaline complexes (Pell, 1994; Millonig et al., 2012; Dalsin et al., 2015). Among them, the Aley (niobium), Rock Canyon (REE), and Wicheeda (REE) alkaline complexes contain the highest concentrations of niobium and the REE.

The rocks underlying the alkaline province belong to the Middle Proterozoic Purcell Supergroup and comprise primary clastic and carbonate rocks $>20 \mathrm{~km}$ thick deposited 
between 1700 and 780 Ma (Monger et al., 1972; Sears and Price, 1978; Monger and Price, 1979). Late Proterozoic (780-570 Ma) strata comprising gritty feldspathic sandstones, locally also volcanic rocks, and carbonate rocks lie unconformably over the Purcell Supergroup. They show evidence of having been subjected to glacial activity, and are disconformably overlain by Early Cambrian to Late Jurassic sedimentary rocks (Monger, 1989). The latter comprise thin platform carbonates, which pass into thin, deeper-water argillaceous shales deposited along a complex passive margin.

On the basis of $\mathrm{U}-\mathrm{Pb}$ and $\mathrm{Th}-\mathrm{Pb}$ age determinations conducted on samples from various localities within the alkaline province, the latter is interpreted to have formed during three episodes of magmatism (e.g., Millonig et al., 2012). The first episode (800-700 Ma) coincided with the breakup of Rodinia, and the other two (500 Ma, 360-340 Ma) with subsequent periods of extension. Most of the alkaline complexes hosting economic mineralization were emplaced during the youngest of these three episodes.

The rocks surrounding the Wicheeda Carbonatite and nearby dikes and sills comprise steeply dipping limestone, marble, siltstone, argillite, and calcareous sedimentary rocks belonging to the Upper Cambrian to Lower Ordovician Kechika Group (Fig. 2; Armstrong et al., 1969; Taylor and Stott, 1979). These rocks are in fault contact with Cambrian to Devonian carbonates, slates, and siltstones east of the complex, and to the west are in fault contact (McLeod Fault) with Upper Proterozoic to Permian Gog Group quartzites and unassigned Devonian to Permian felsic volcanic rocks (Lane, 2009). The faults bound the McGregor plateau in which the Wicheeda Complex is located; the 
eastern fault is an extension of the Rocky Mountain Trench, and is the dominant structural feature in the area (Armstrong et al., 1969). 


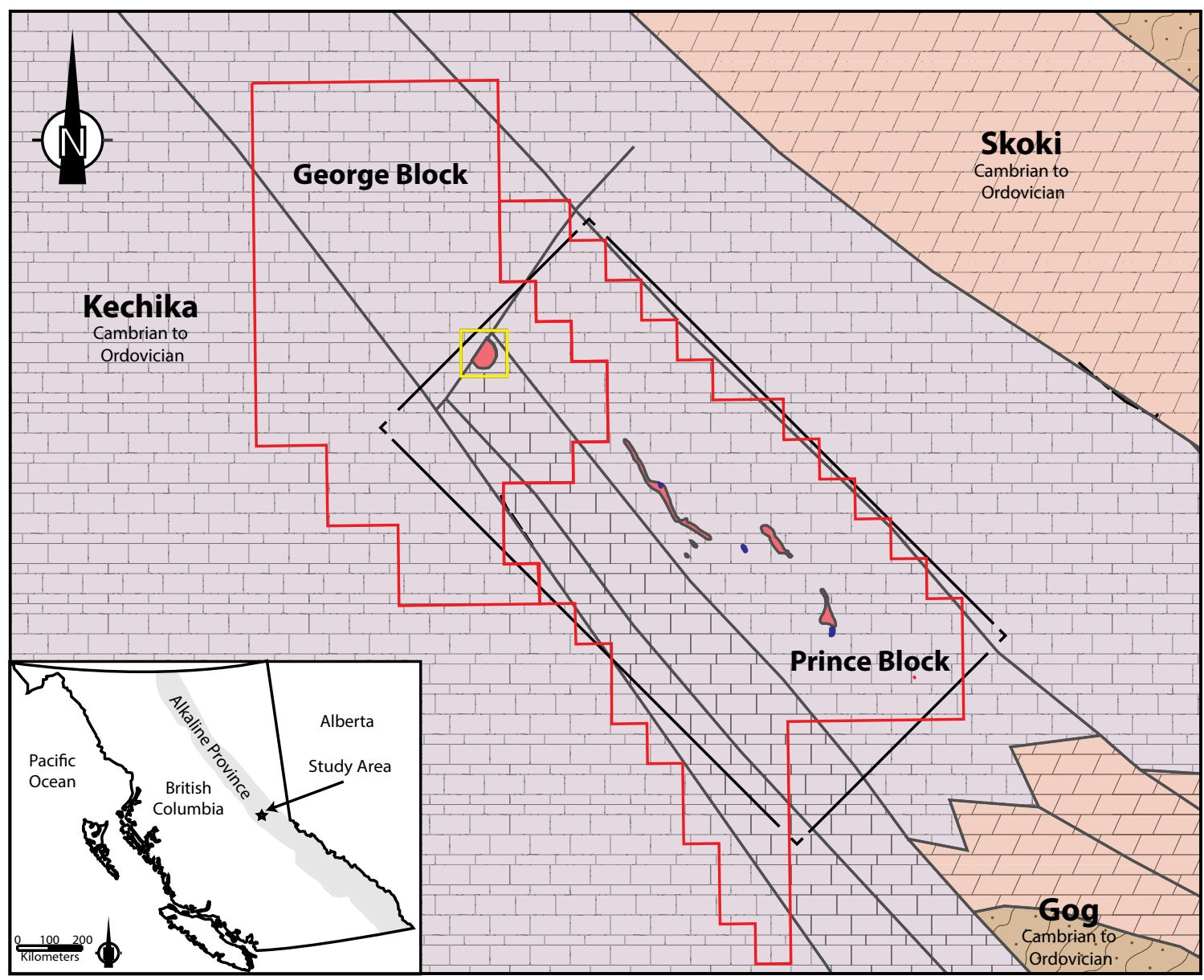

\section{Stratified Rocks}

Cambrian to Ordovician

Kechika Group

Limestone, marble, shale

Skoki Formation

Dolomitic sedimentary rocks

Upper Proterozoic to Cambrian

$\therefore$ Gog Group

Quartz arenite, clastic sedimentary rocks

\section{Intrusive Rocks}

\section{Carboniferous}

\section{Wicheeda Carbonatite}

Calcite to dolomite carbonatite

Syenite

K-feldspar bearing syenite

- Fault

Study Area

Outline of exploration claims

$i_{-}^{-}$] Outline of aeromagnetic map (Fig. 3)

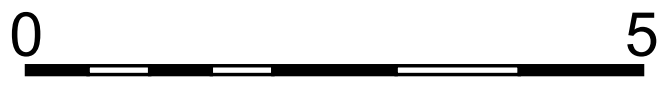

\section{Kilometers}

Fig. 2: The location of the Wicheeda carbonatite and other nearby carbonatite and alkaline silicate dykes and sills within the Foreland belt sedimentary succession. The locations of the George and Prince claim blocks are outlined as are the limits of the aeromagnetic map shown (rectangle outlined with black dashed lines) in Figure 3. The inset image shows the location of the Wicheeda carbonatite in the British Columbia alkaline prquince. 
The Wicheeda Carbonatite explored by Spectrum Mining Corporation, and the focus of the present study, is a $250 \mathrm{~m}$ diameter body inferred to be a plug, which was described by Mäder and Greenwood (1988) as a uniform ankerite carbonatite containing potassium feldspar and a "parisite-like" rare earth carbonate mineral. The intrusion is steeply dipping to the west and is in contact with fenite (Lane, 2009; 2010).

\section{Exploration History}

There has been limited exploration of the Wicheeda Complex until recently. A prospector, Kol Lovang, first sampled the area in the 1970s and staked claims based on elevated concentrations of several base metals. However, no follow up work was conducted and the claims were permitted to lapse. In the 1980s Teck Explorations Ltd. assayed Lovang's samples and obtained elevated niobium values, prompting the company to conduct a preliminary exploration program including geological and geophysical mapping, soil sampling, trenching, and stream sediment sampling. Based on the results of this exploration, Teck identified areas for further exploration and staked several blocks of claims including the George and Prince blocks, which are presently held by Spectrum Mining Corp. and Canadian International Minerals Inc., respectively (Fig. 2). Test pits and trenches were blasted on both claims. Soil samples analyzed from the George Grid yielded high TREE concentrations (up to $4.2 \mathrm{wt} . \%$ ) and $\mathrm{Nb}$ concentrations up to 0.07 wt.\%, whereas the Prince Grid samples contained low TREE concentrations ( $<0.2$ wt.\%) but higher $\mathrm{Nb}$ concentrations (up to 0.24 wt.\%).

In 2008, Spectrum Mining Corp. began a diamond drilling exploration program on the Wicheeda Carbonatite (Lane, 2009). Four holes were drilled from a single drill set-up in 
a fan-like pattern, with a total length of $866 \mathrm{~m}$, and intersected dolomite carbonatite at surface, and carbonatite breccia and fenite at depth. One hole terminated in calcite carbonatite. Drill core logging and geochemical analyses showed that the dolomite carbonatite is strongly REE-enriched, preferentially in the light REE (LREE). Anomalous concentrations of Mo, Ba, Sr, Mn, As, P, Y, Th were observed (Lane, 2009). Petrographic examination of the dolomite carbonatite revealed the presence of accessory potassium feldspar and albite, and traces of niobian rutile, biotite, pyrochlore, thorite, pyrite, galena, and molybdenite (Lane, 2009). The dominant REE minerals identified were Ca-REE-fluorocarbonates interpreted to be parisite-(Ce), röntgenite-(Ce), or synchysite-(Ce); monazite-(Ce) was also observed. Allanite and euxenite were identified in one sample.

Additional drilling (14 holes for a total length of $1835 \mathrm{~m}$ ) was carried out in 2009 from three drill sites, two within the Wicheeda Carbonatite and one located on a much smaller intrusion 400 m north of the Wicheeda Carbonatite. The drill holes within the Wicheeda Carbonatite, which were mainly inclined, intersected REE-mineralized dolomite carbonatite in their upper parts, calcite carbonatite at depth, and in most cases terminated in fenite (Lane, 2010). A single, northerly inclined drill hole (WI09-14) terminated in calcite carbonatite barren of REE. The three holes drilled to the north of the Wicheeda Carbonatite all intersected coarse-grained calcite carbonatite but no significant REE mineralization $(<1 \%$ TREO). Based on the results of the drilling in 2008 and 2009, the Wicheeda Carbonatite was estimated to contain a resource of 11.3 million tons grading 
$1.95 \% \mathrm{Ce}+\mathrm{La}+\mathrm{Nd}$, mainly as coarse-grained bastnäsite- $(\mathrm{Ce})$ and monazite- $(\mathrm{Ce})$ (Lane, 2010).

In July 2010, Canadian International Minerals Inc. conducted a 566.1 line-km HelicopterBorne AeroTEM System Electromagnetic, Magnetic, and Radiometric Survey of the Wicheeda Carbonatite and the Prince claims to the southeast. Magnetic and radiometric anomalies were observed on the George claims, including a small $(<150 \mathrm{nT})$ ellipsoidal anomaly over the Wicheeda Carbonatite and linear anomalies on the Prince claims (Fig. 3; Bruland, 2011). Diamond drilling on the Prince claims by Canadian International Minerals Inc. revealed a series of carbonatite dikes and veins, and mafic dikes (Bruland, 2011; Dalsin and Groat, 2011). The best REE intersection was 4.68 wt.\% TREO over 0.9 m (largely as Ca-REE-fluorocarbonates, Ba-REE-fluorocarbonates, ancylite-(Ce), monazite-(Ce), euxenite-(Y), and allanite-(Ce)) in calcio- to ferro-carbonatite dikes. 


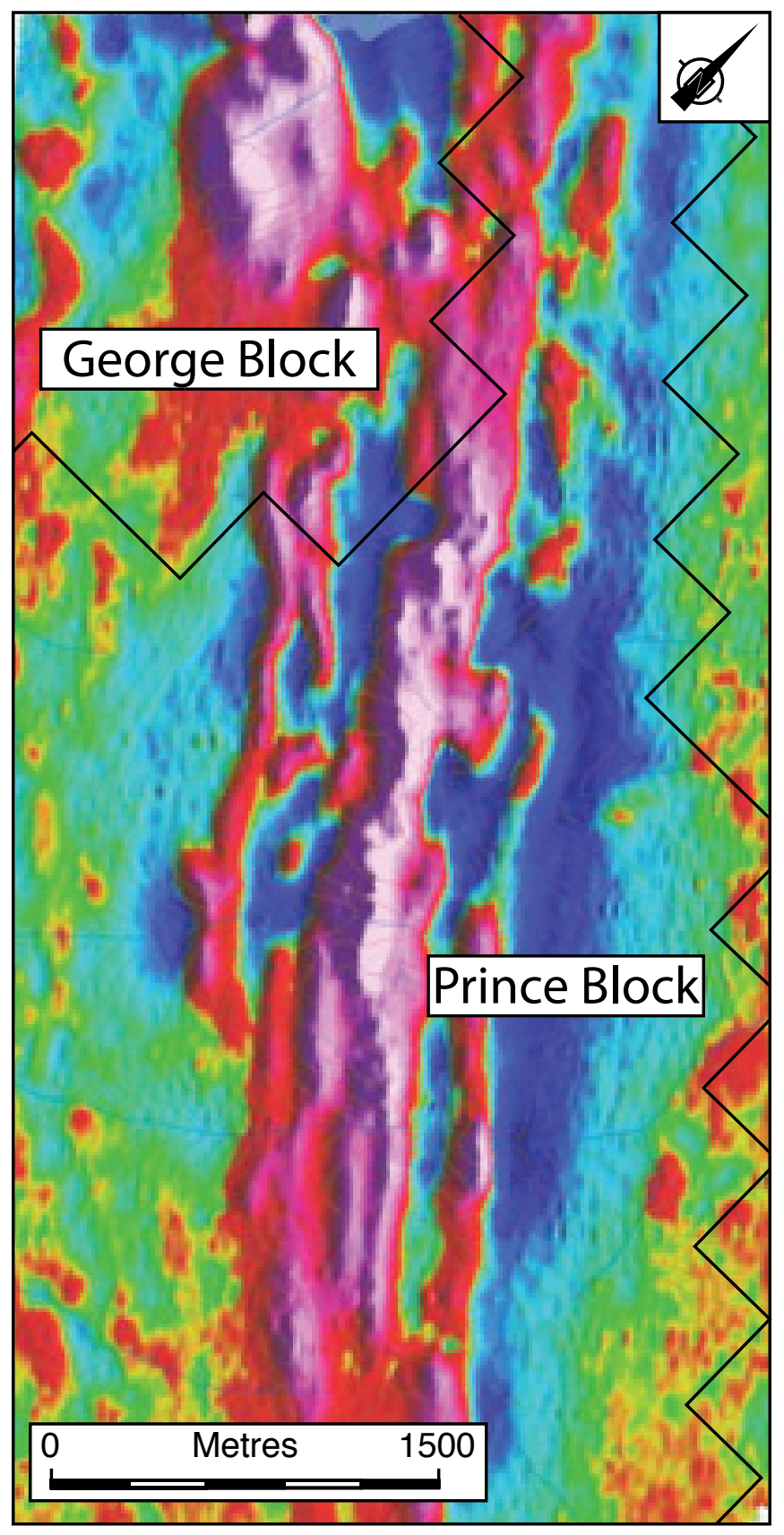

Fig. 3: A magnetic gradient map of the Wicheeda Complex from Bruland (2011a) prepared for Canadian International Minerals Inc. by Aeroquest International Ltd. The exploration rights to the George claims, on which the Wicheeda carbonatite is located, and the neighboring Prince claims are presently held by Spectrum Mining Corp., and Canadian International Minerals Inc., respectively. 


\section{Methodology}

\section{Bulk Lithochemistry}

Samples of outcrop and drill core from four holes drilled by Spectrum Mining Corp. in 2008 and 2009 were analyzed by ALS Minerals in Vancouver for their bulk and trace element compositions. All samples were ground using a steel mill. Samples were subjected to lithium metaborate fusion, digested in $100 \mathrm{~mL}$ of $4 \%$ nitric acid/ $2 \%$ hydrochloric acid and analyzed by Inductively Coupled Plasma Emission Spectrometry for the major elements and Inductively Coupled Plasma Mass Spectrometry for the trace elements. Loss on ignition (LOI) was determined after fusion. The carbon and sulfur contents were determined using the LECO combustion method. The fluorine content was determined for a subset of samples by potassium hydroxide fusion followed by leaching in de-ionized water and analysis by an ion selective electrode. The results are summarized in Table 1. 


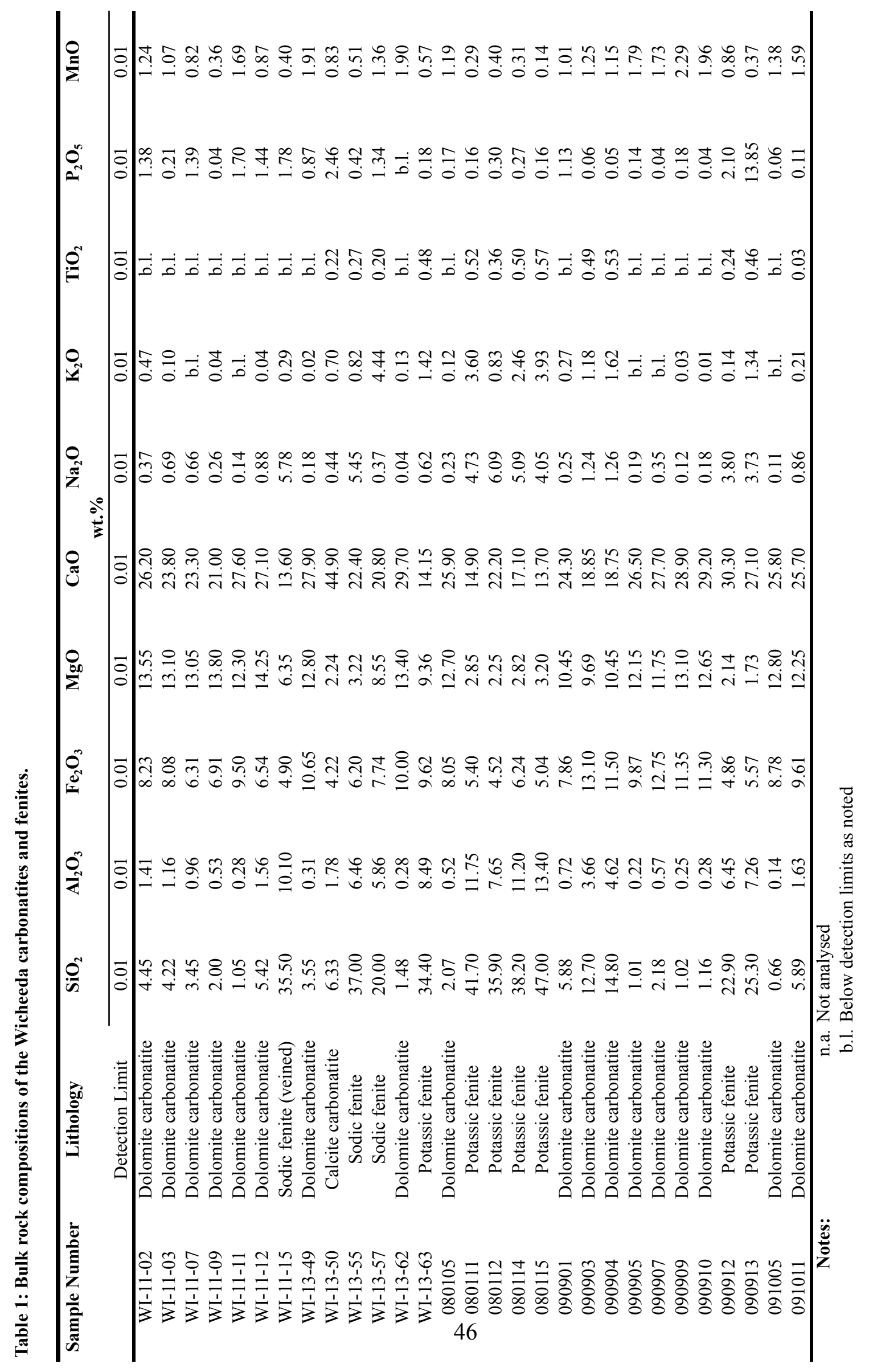




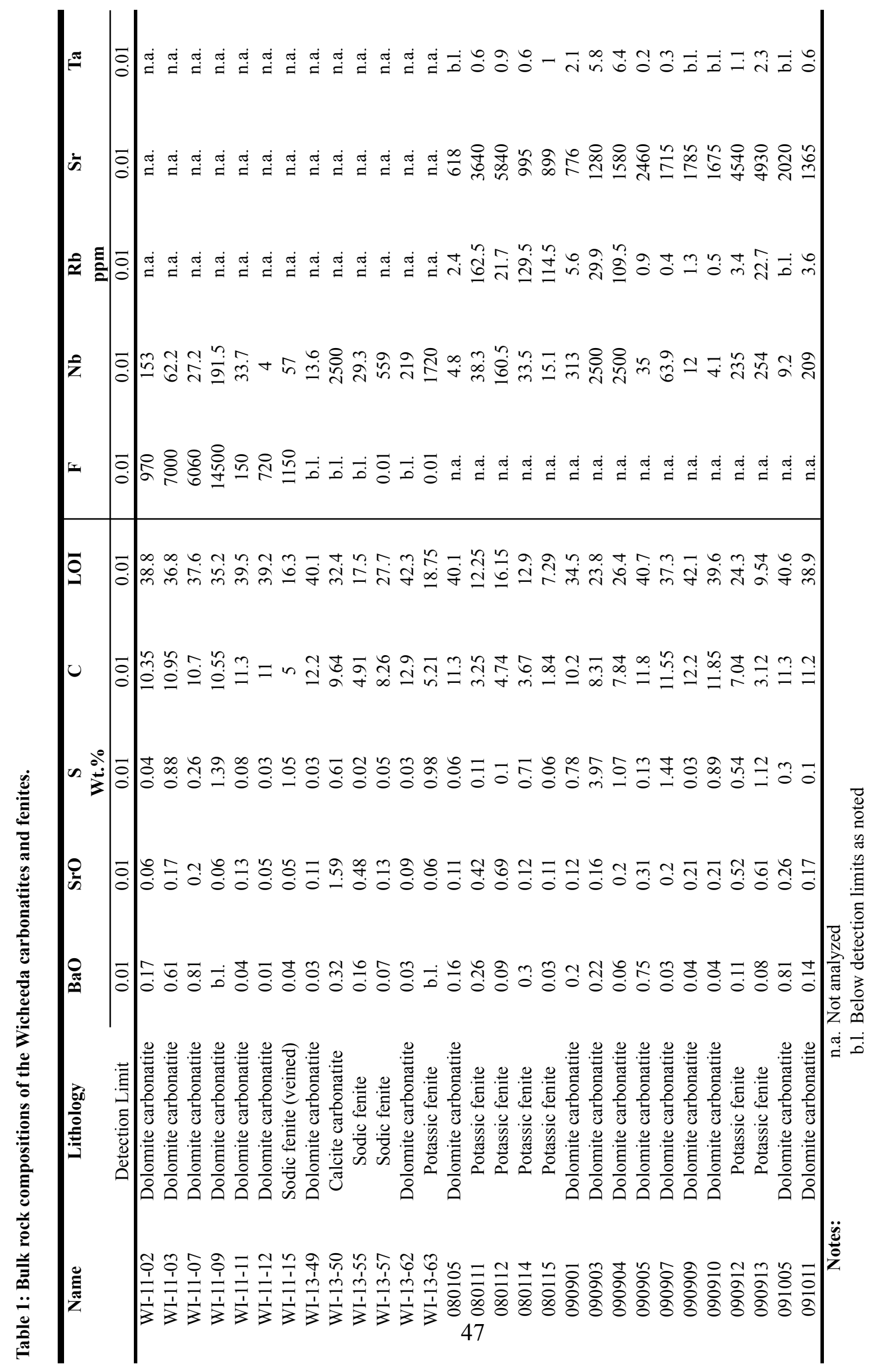




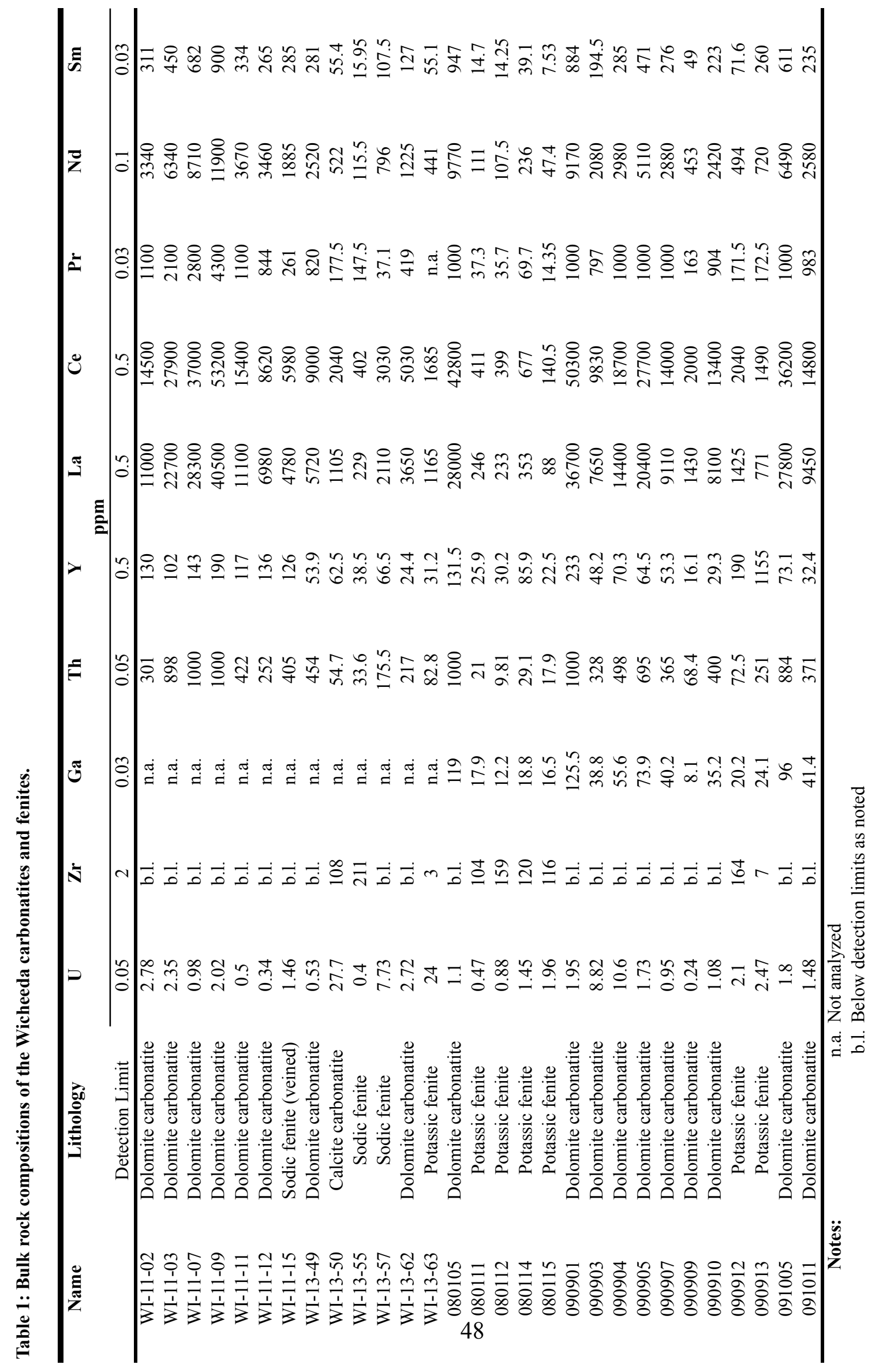




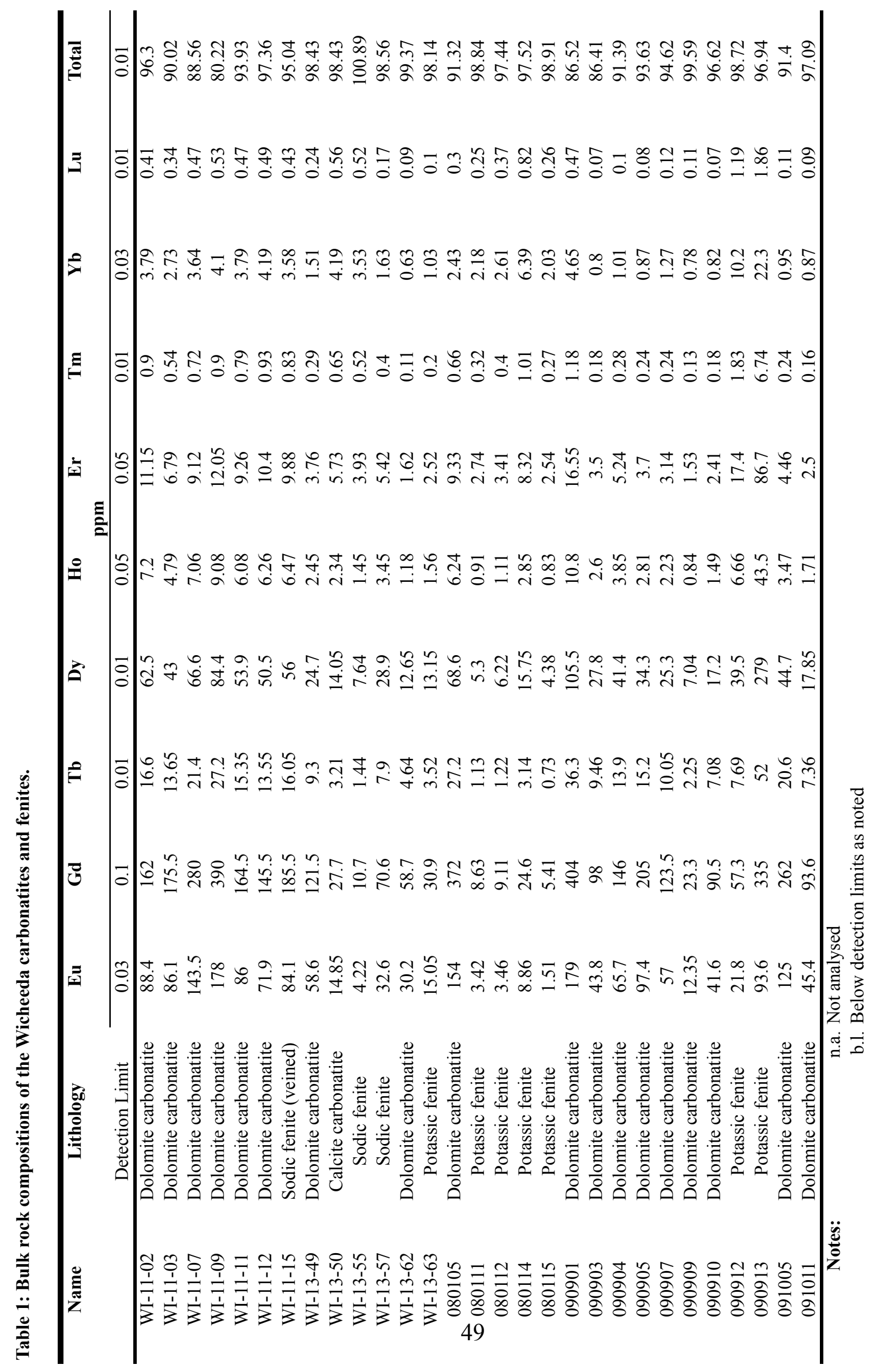




\section{Mineral Chemistry}

Mineral compositions were determined at McGill University using a JEOL JXA-8900L electron microprobe equipped with five wavelength-dispersive spectrometers and a $\mathrm{Si}(\mathrm{Li})$ energy-dispersive detector. Spot analyses using wavelength-dispersive spectrometry, were conducted at $20 \mathrm{kV}$ with a $30 \mathrm{nA}$ beam current and a $10 \mu \mathrm{m}$ beam diameter for dolomite, feldspar, and the mafic minerals, and a $5 \mu$ m beam diameter for apatite, the $\mathrm{Sr}$ REE-carbonates, REE-fluorocarbonates, and REE-phosphates. Data reduction was performed using a ZAF correction procedure. The standards and counting times used are reported in Appendix C. Detection limits for each mineral are available with their analytical data in Appendices D-K. Table 2 lists the minerals mentioned in the text with their idealized chemical formulae. 


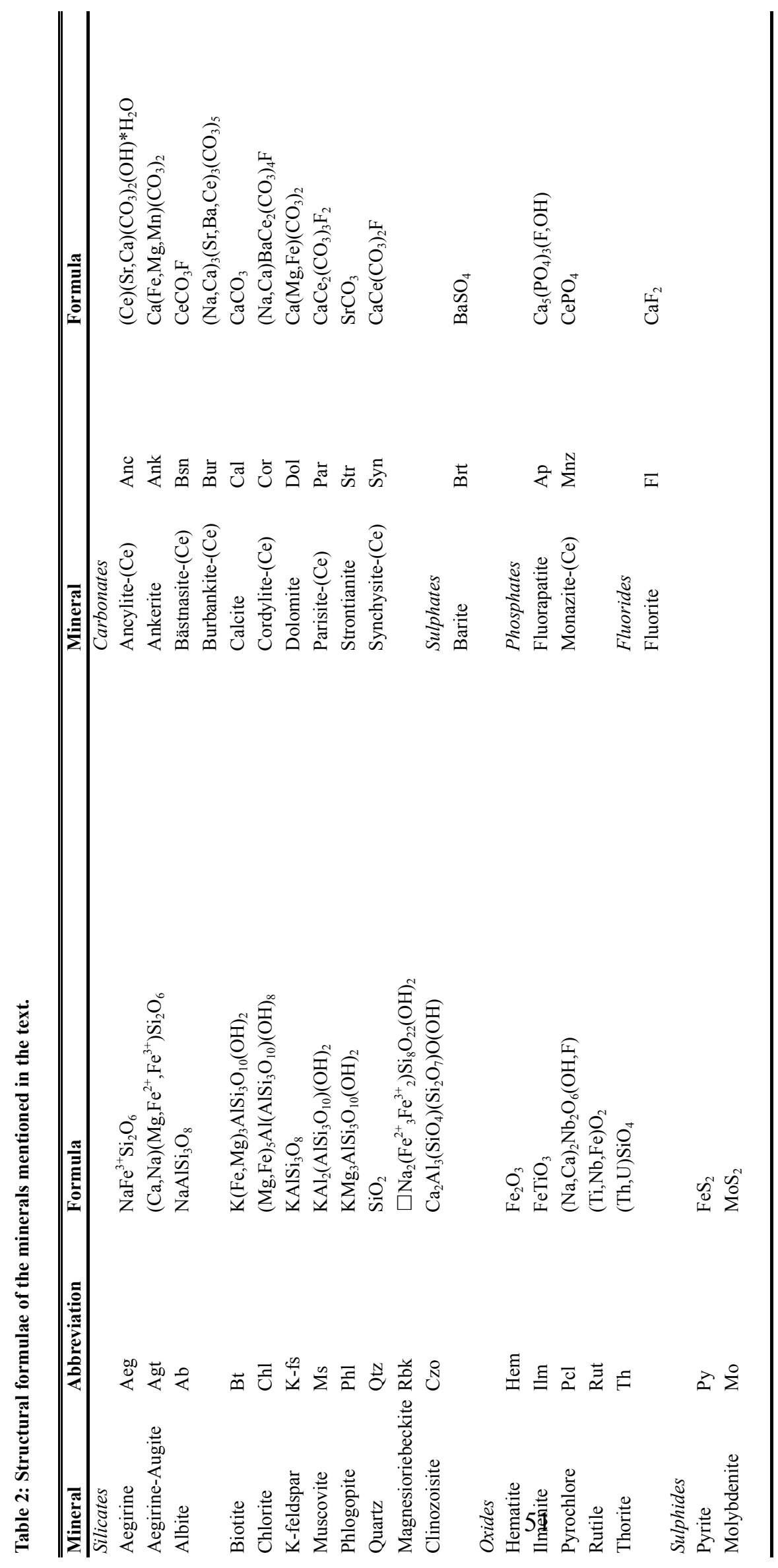




\section{Stable Isotopes}

Samples of calcite and dolomite were analyzed for their contents of stable carbon $\left({ }^{12} \mathrm{C}\right.$ and $\left.{ }^{13} \mathrm{C}\right)$ and oxygen $\left({ }^{16} \mathrm{O}\right.$ and $\left.{ }^{18} \mathrm{O}\right)$ using a $\mathrm{Nu}$ instruments isotope-ratio mass spectrometer at McGill University. All samples were ground using a drill press. Carbon dioxide was released by reaction with phosphoric acid and transferred cryogenically to a dual micro inlet followed by isotopic measurement. The carbon isotopic ratios were standardized to Vienna Pee Dee Belemnite (V-PDB) and reported as $\delta{ }^{13} \mathrm{C}$ values and the oxygen isotopic ratios to Vienna Standard Mean Ocean Water (V-SMOW) and reported as $\delta{ }^{18} \mathrm{O}$. A total of 20 samples were analyzed.

\section{Local Geology}

The study area is centered on the Wicheeda Carbonatite, which is separated by a later NE-SW trending fault from Kechika Group slates to the west (Fig. 4). A second northwest-southeast trending fault identified by a photo-lineament is cut by this fault and does not appear to have displaced either the carbonatite or surrounding rocks. To the east, fenitized Kechika Group argillaceous limestones surround the Wicheeda Carbonatite. These comprise a proximal potassic fenite extending up to about $80 \mathrm{~m}$ from the carbonatite and a distal fenite that includes the most southerly and easterly outcrops in the study area exclusive of carbonatite and fenite. Small outcrops of carbonatite occur to the east and northeast of the Wicheeda Carbonatite and a felsic dyke is exposed in the northeast. 


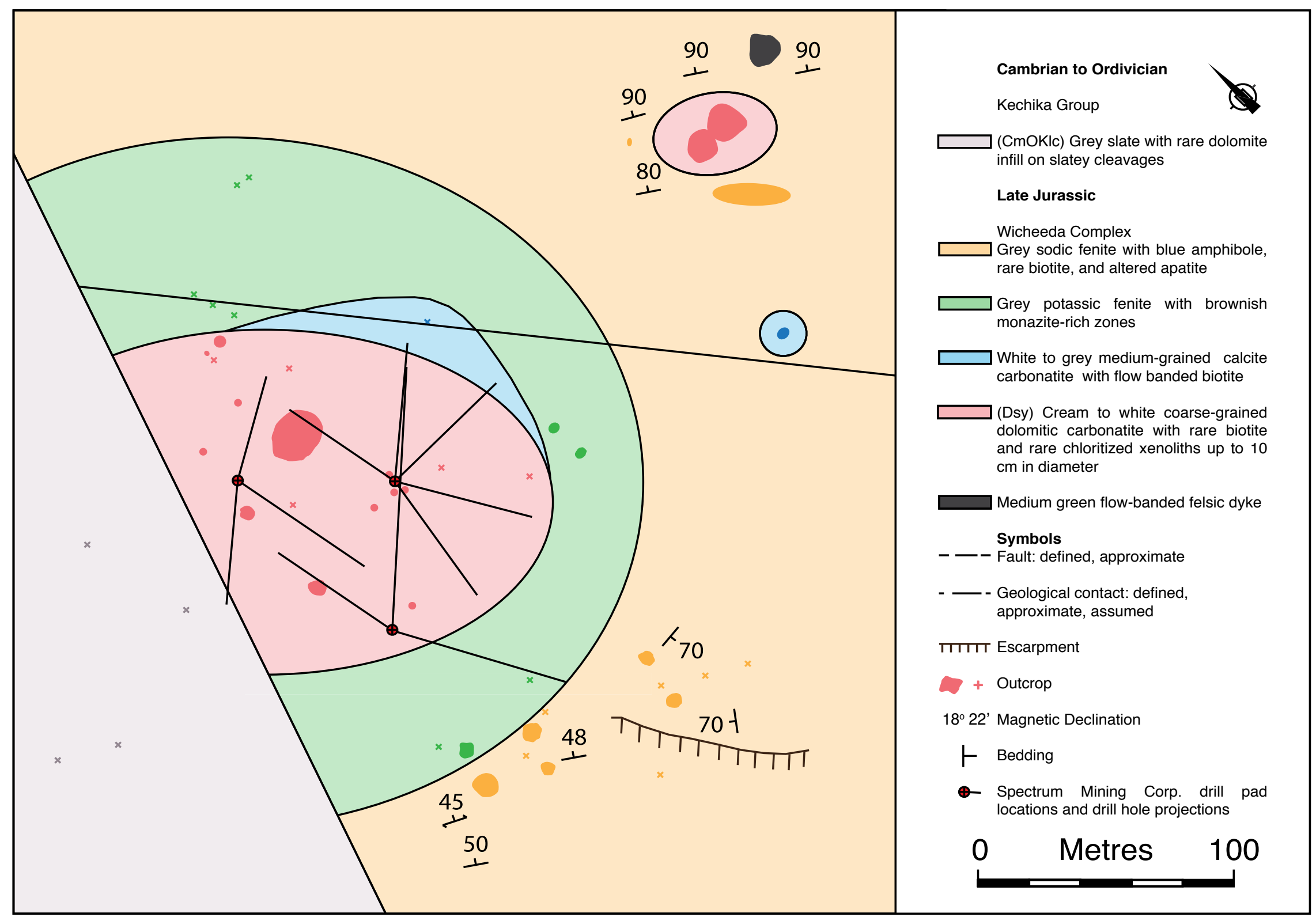

Fig. 4: Geological map of the Wicheeda carbonatite and environs. 


\section{Kechika Group Metasedimentary Rocks}

The Kechika Group metasedimentary rocks exposed west of the NE-SW trending fault comprise weakly foliated grey slates with a well-developed cleavage and fractures infilled by dolomite. Elsewhere in the study area, as mentioned above, the Kechika Group rocks have been fenitized. To the north, east and south (east of the NE-SW trending fault) of the study area, they comprise thickly bedded limestone and argillaceous limestone striking from $320^{\circ}$ to $350^{\circ}$ and dipping from $45^{\circ}$ to $90^{\circ}$. The beds typically show a fining-upward sequence of limestone to silty argillaceous limestone comprising millimeter-scale calcite-rich and silt- to clay-rich laminations, and are capped by clay ripup clasts. The calcite-rich laminations are composed of clear anhedral, sutured calcite grains up to $300 \mu \mathrm{m}$ in diameter and subordinate zoned subhedral apatite crystals with inclusion-rich (calcite) cores and clear, inclusion-poor rims; the apatite is concentrated near the argillaceous silty laminations. The silt-/clay-rich laminations comprise subhedral quartz $(100 \mu \mathrm{m})$, clay minerals, and subordinate fine-grained $(<100 \mu \mathrm{m})$ anhedral calcite.

\section{The Wicheeda Carbonatite}

With the exception of a small zone on its northeastern flank where it passes gradationally into calcite (Fig. 4), the Wicheeda carbonatite is exclusively dolomitic. Small outcrops of dolomite carbonatite and calcite carbonatite are also present $\sim 150 \mathrm{~m}$ northeast and $100 \mathrm{~m}$ east of the main intrusion, respectively (Fig. 4). The dolomite carbonatite is heavily oxidized to a dark orange or brown color in outcrop and to depths of up to $5 \mathrm{~m}$ in drill core. Where fresh, it is cream or white in color and is extremely vuggy with fractures 
commonly infilled by dolomite and REE minerals (Fig. 5A to 5D). Near the contact with the potassic fenite, corroded clasts of albite + apatite up to $3 \mathrm{~cm}$ in diameter have been incorporated into the carbonatite. Large euhedral dolomite crystals up to $2 \mathrm{~cm}$ in diameter comprise 65 to 70 vol.\% of the rock and are accompanied by vein and vug-filling potassium feldspar (5 to 10 vol.\%), dark micas (5-10 vol.\%), calcite (5 vol.\%), hematite (2 to 5 vol.\%), pyrite (1 to 3 vol.\%), and barite (1-2 vol.\%). Rare earth element-bearing carbonate minerals, including bastnäsite-(Ce), parisite-(Ce), synchysite-(Ce), ancylite(Ce) and cordylite-(Ce), and monazite-(Ce) make up between 3 to 6 vol.\% of the rock. Traces of molybdenite, niobian rutile, and thorite are also present. Three texturally distinct varieties of dolomite have been recognized (Fig. 5B and 5C). Dolomite 1 is characterized by relatively clear (inclusion-poor) euhedral rhombs up to $1 \mathrm{~cm}$ in diameter with well-developed cleavages and triple junction grain boundaries, which are locally lined by hematite. In very rare cases, the cleavages are curved and contain microcrystalline dolomite within them. Dolomite 1 makes up most (>90 vol.\%) of the dolomite in the carbonatite. The second variety, Dolomite 2, comprises dusty micro-fluid inclusion-rich $(<2 \mu \mathrm{m})$ cryptocrystalline carbonate surrounding vugs and veins (Fig. 5B). Large euhedral crystals of compositionally zoned Dolomite 3 occur in veins and as a cavity-lining phase with semi-continuous growth rims containing primary fluid micro-inclusions ( $<2 \mu \mathrm{m}$ diameter) (Fig. 5B). 

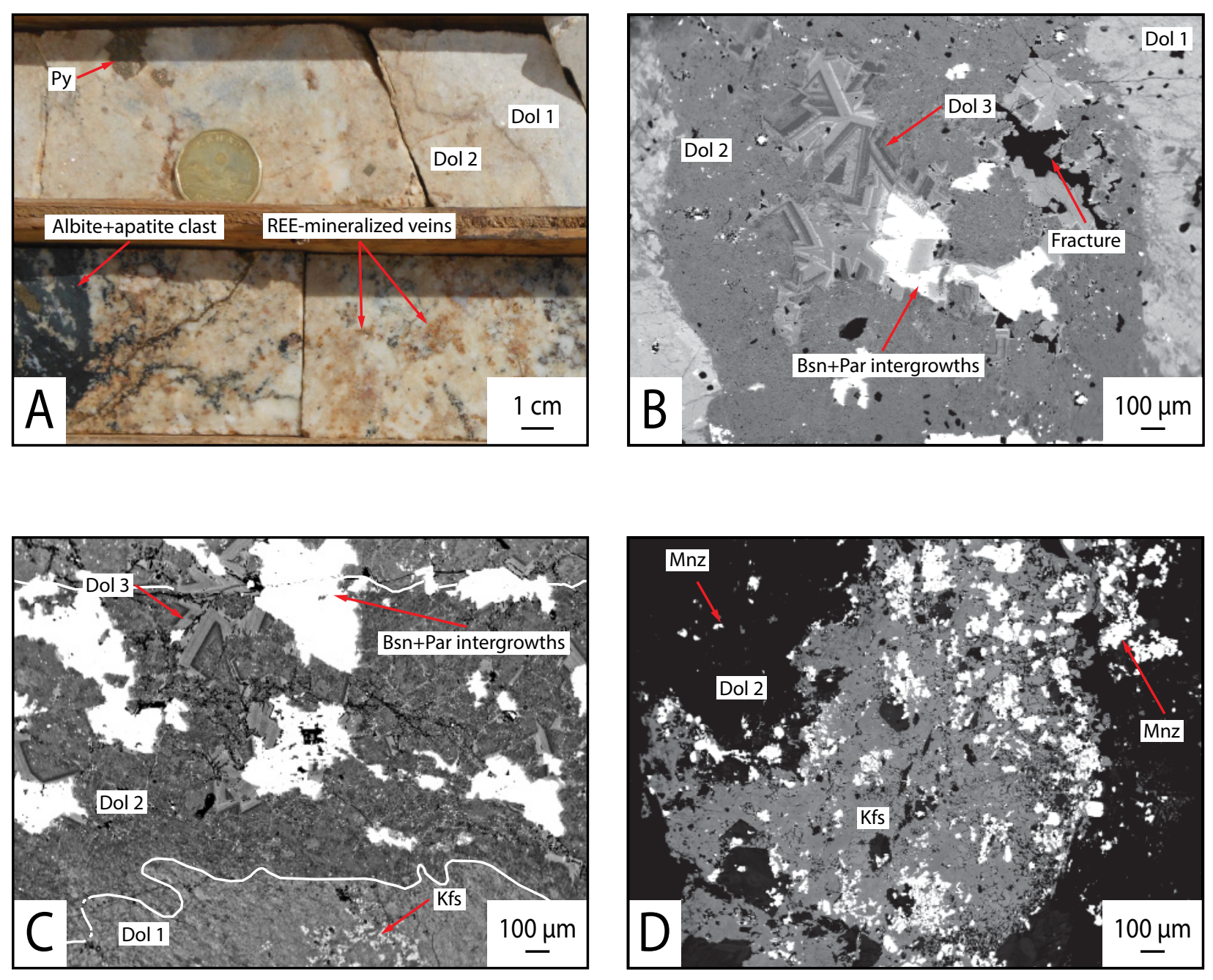

Fig. 5: A. White (Dolomite 1) to cream (Dolomite 2) dolomite carbonatite with bright orange REE-mineralized veinlets. Xenoliths of sodic fenite up to $30 \mathrm{~cm}$ have been incorporated into the carbonatite. Pyrite occurs in veinlets and as blebby subhedral grains. B. Back-scattered electron image of dolomite carbonatite (sample 080101) showing relatively clear Dolomite 1 (light grey) altered to Dolomite 2 near vugs infilled by Dolomite 3 and bastnäsite- $(\mathrm{Ce})$ and parisite-(Ce) (bright). C. Back-scattered electron image of dolomite carbonatite (sample WI080101) showing Dolomite 1 altered to Dolomite 2 near vugs partially infilled by Dolomite 3 and bastnäsite-(Ce) and parisite-(Ce). D. Back-scattered electron image of dolomite carbonatite (sample WI090802) showing a vug infilled with K-feldspar and monazite-(Ce). 
The calcite carbonatite comprises white, medium-grained, equigranular calcite (65 vol.\%) replaced by Dolomite 1 (15-20 vol.\%; Fig. 6A) with minor biotite (5 vol.\%), albite (5 vol.\%), aegirine-augite ( 2 vol.\%), pyrite ( 2 vol.\%), and pyrochlore (1 vol.\%) and traces of apatite. It displays evidence of strong flow banding with alternating millimeter-thick layers of biotite and $5 \mathrm{~mm}$-thick calcite-rich layers (Fig. 6B). Fine-grained $(<100 \mu \mathrm{m})$ subhedral to anhedral albite commonly contains inclusions of rounded calcite $(10 \mu \mathrm{m})$ and is locally altered to clinozoisite. Emerald-green, euhedral aegirine crystals up to 400 $\mu \mathrm{m}$ in diameter form clusters near the contact with the dolomite carbonatite and are commonly rimmed by brown euhedral biotite (Fig. 6C). Brown, euhedral pyrochlore grains up to $25 \mu \mathrm{m}$ in diameter occur as inclusions in calcite and rarely in biotite (Fig. 6C). Pyrite and clinozoisite occur locally in cavities (Fig. 6D). 

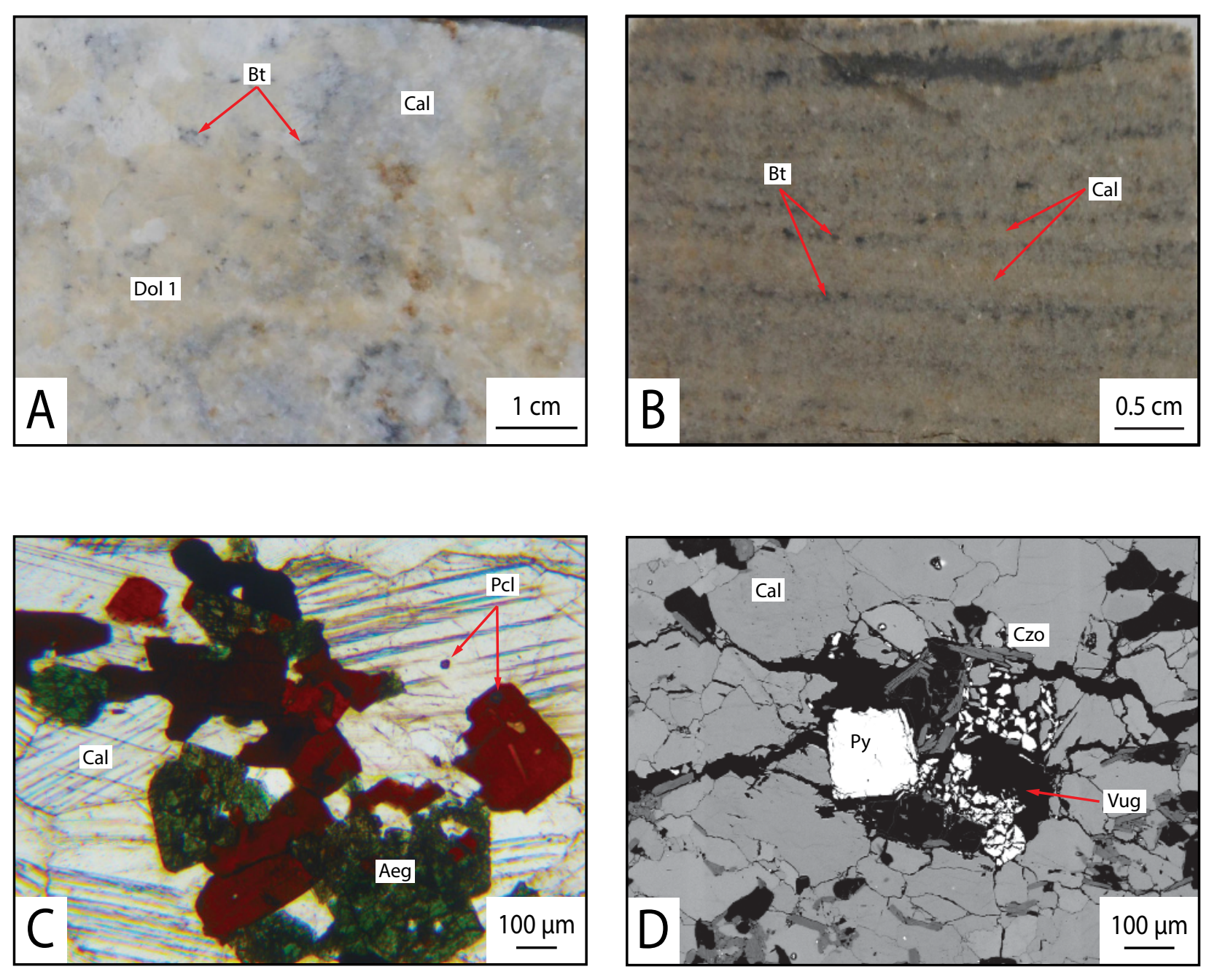

Fig. 6: A. Drill core from WI-09-08 (49 m depth) of grey calcite carbonatite comprising calcite (Cal), and containing white Dolomite 1 and dark Fe-rich biotite $(\mathrm{Bt})$ grains. B. Photograph of calcite carbonatite with alternating dark grey biotite-rich and white to light grey calcite layers. C. Plane-polarized photomicrograph of calcite carbonatite (WI-09-08) with equigranular calcite, emerald-green aegirine (Aeg), and reddish-brown biotite (Bt). Traces of pyrochlore (Pcl) occur as inclusions in calcite and biotite. D. Back-scattered electron image showing fractured calcite carbonatite containing a vug partially infilled by pyrite, zoisite, and albite; albite is also disseminated in the matrix of the carbonatite. 


\section{Potassic Fenite}

The potassic fenite outcrops poorly and descriptions of it come mainly from examination of the drill core. The fenite varies in color from beige (strongly altered) near the intrusion to grey (weakly altered) further from the carbonatite-fenite contact (Fig. 7A). Mineralogically, the potassic fenite comprises potassium feldspar (30 to 35 vol.\%), biotite (15 to 20 vol.\%), albite (15 to 25 vol.\%), calcite (10-15 vol.\%), and aegirineaugite (5-10 vol.\%), together with traces of magnesioriebeckite, apatite, rutile, monazite(Ce), and ancylite-(Ce). The potassium feldspar occurs as blebby, anhedral aggregates up to $0.5 \mathrm{~mm}$ in diameter in clots with fine-grained albite (Fig. 7B) and as larger crystals that clearly replaced albite. Fine-grained anhedral calcite is interstitial to potassium feldspar and albite, and is rimmed by dolomite. Aegirine-augite occurs locally and is found most commonly in the distal parts of the potassic fenite where it forms acicular crystals. Riebeckite commonly occurs with the aegirine-augite and shows evidence of replacement by biotite (Fig. 7C). Biotite also occurs as large, euhedral crystals rimmed by chlorite in veinlets with calcite. Subhedral niobian rutile with inclusions of albite and potassium feldspar is found in the altered biotite rims. Strongly zoned, blue to violet luminescent, subhedral to anhedral fine-grained apatite (Apatite 1) with albite inclusions is disseminated in the albite-potassium feldspar clots. This apatite is replaced by finegrained monazite-(Ce); the latter occurs in contact with potassium feldspar and near dolomite veinlets (Fig. 7D). 

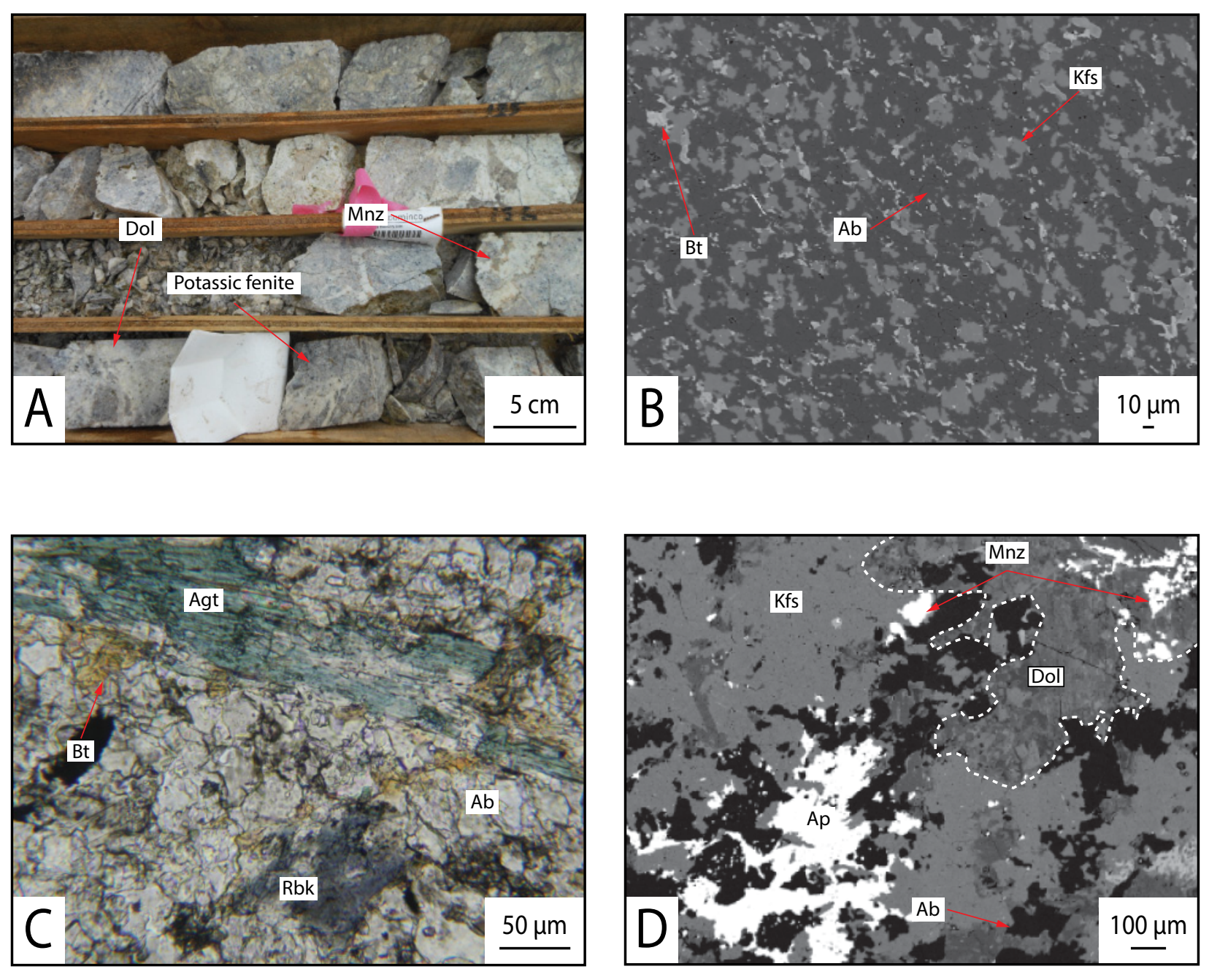

Fig. 7: A. Intensely altered potassic fenite from drill hole WI-09-08 ( 135 $\mathrm{m}$ depth) with beige clots of monazite-(Ce) at the contact between the fenite and dolomite-filled fractures. B. Back-scattered electron image of mottled dark grey albite $(\mathrm{Ab})$ in potassic fenite replaced by medium-grey K-feldspar (Kfs) and light grey biotite (Bt). C. Photomicrograph in plane-polarized light of outcrop sample of potassic fenite (WI-13-55) containing acicular blue-green acicular aegirine-augite (Agt) and blue-grey riebeckite that has been replaced by biotite in clear albite $(\mathrm{Ab})$ and K-feldspar (Kfs). D. Back-scattered electron image of potassic fenite showing anhedral Apatite 1 (Ap) with inclusions of albite (Ab) near aggregates of monazite-(Ce) (Mnz) at the contact between K-feldspar and dolomite (dashed line). 


\section{Sodic Fenite}

Macroscopically, the sodic fenite resembles the unaltered Kechika Group rocks and is distinguished from them by the presence of abundant calcite veinlets, particularly near the contact with the potassic fenite. The sodic fenite consists mainly of albite (25 to 35 vol.\%), calcite ( 25 to 35 vol.\%), aegirine (10 to 15 vol.\%) and riebeckite (5 to 10 vol.\%). Relict sedimentary bedding locally survived fenitization and is preserved as alternating albite + aegirine \pm calcite, and calcite-rich laminations (Fig. 8A,B). In the former laminations, albite laths up to $100 \mu \mathrm{m}$ in length occur with bundles of acicular aegirine crystals up to $1 \mathrm{~mm}$ in length (Fig. 8B). The albite laths commonly contain inclusions of very fine-grained $(5 \mu \mathrm{m})$ anhedral calcite crystals. Within the aegirine + albite laminations, rare, pale blue-grey riebeckite forms spongy masses up to $200 \mu \mathrm{m}$ in diameter and fibrous needles after aegirine. Biotite occurs as fine-grained disseminated flakes and larger $(200 \mu \mathrm{m})$ crystals rimmed by chlorite (Fig. 8C,D) in veins with calcite and rare siderite (Fig. 8C). Apatite 2 (1 to 2 vol. \%) forms euhedral to subhedral, weakly zoned crystals up to $200 \mu \mathrm{m}$ in diameter disseminated throughout the albite+calcite matrix and commonly forms aggregates (Fig. 8C). It has an albite-calcite inclusion-rich core and a clear rim, and is concentrated in the albitic laminations. Very fine-grained calcite and pyrite (oxidized in surface exposures) also occur in these laminations. The calcite-rich laminations are coarser-grained, consisting of sutured crystals up to $800 \mu \mathrm{m}$ in diameter, and only contain traces of REE mineralization. The latter occurs as microveinlets of ancylite-(Ce) in the albite + aegirine laminations or as monazite-(Ce), 
which replaced Apatite 2. This mineralization is only found at or near the contact with the potassic fenite. 

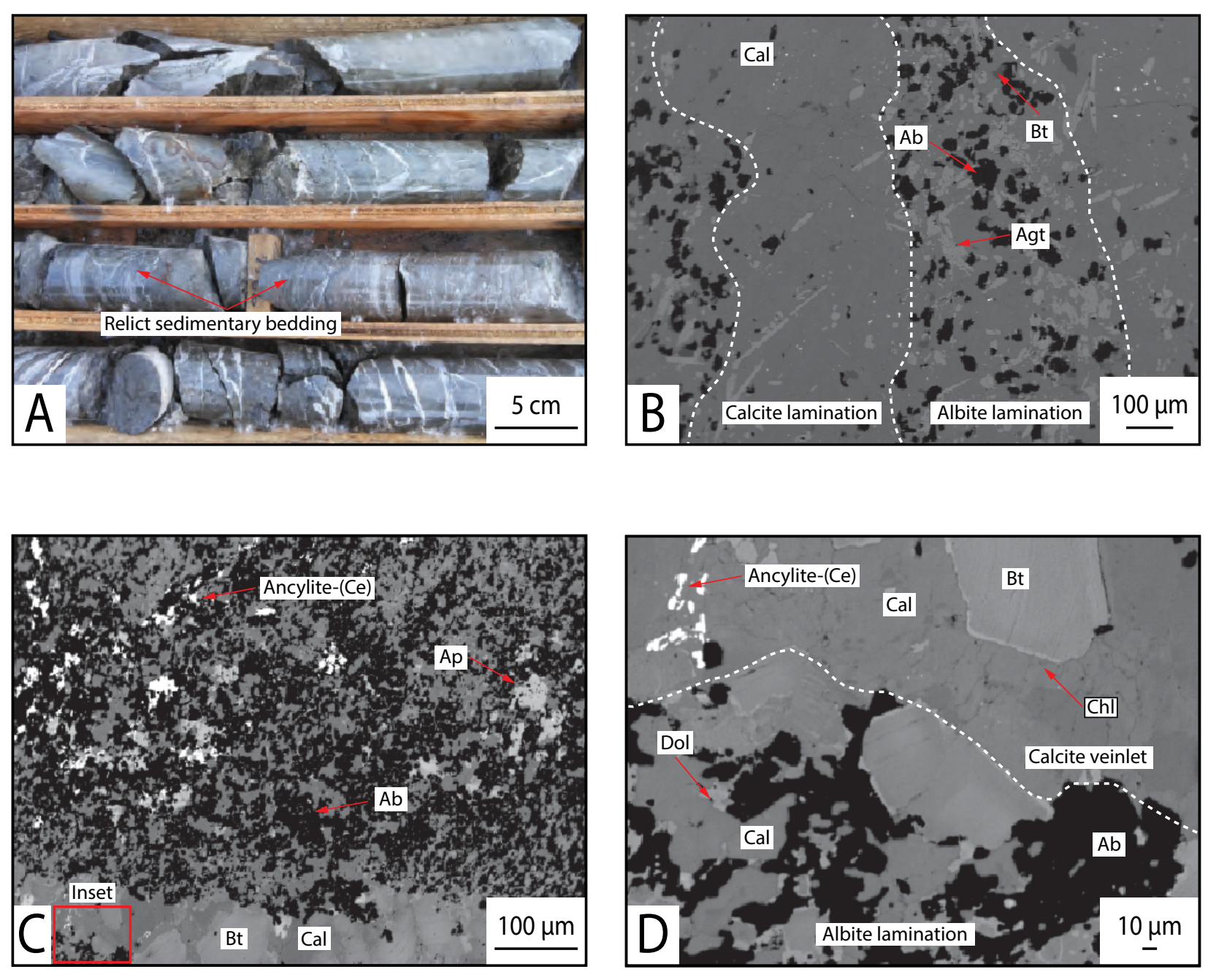

Fig. 8: A. Fractured sodic fenite from drill hole 08-WI-01 (180 $\mathrm{m}$ depth) displaying the relict sedimentary layering of the Kechika Group rocks as alternating pale blue and pale green-grey bands. B. Back-scattered electron image of sodic fenite showing thin alternating calcite-rich (Cal) laminations and aegirine-augite (Agt) - albite (Ab) -rich laminations (sample WI-13-07). Dashed lines indicate the boundaries of the laminations. C. Back-scattered electron image showing mottled albite and calcite and a crosscutting veinlet of calcite $(\mathrm{Cal})$, biotite $(\mathrm{Bt})$, and ancylite-(Ce) from sodic fenite sample WI-13-01. D. Inset of B. showing a calcite+biotite veinlet with biotite rimmed by chlorite (Chl), and traces of ancylite-(Ce). 


\section{Felsic Igneous Rock}

A small outcrop of a felsic igneous rock was identified near the dolomite carbonatite northeast of the main intrusion. It comprises a felty, clay-altered albite matrix; $0.5 \mathrm{~mm}$ wide veinlets of potassium feldspar and a trace of strontianite (crystals up to $100 \mu \mathrm{m}$ in diameter) are common. No REE mineralization was identified in this rock.

\section{Rare Earth Element Mineralization}

As has already been mentioned, the REE mineralization is restricted mainly to the dolomite carbonatite. There, it occurs mostly in veins and vugs, commonly with Dolomite 3 (Fig. 5C) and less commonly as very small grains of monazite-(Ce) disseminated in Dolomite 2 (Fig. 5D). Bastnäsite-(Ce) (2 vol. \%) and parisite-(Ce) (2 vol. \%) form large $(1 \mathrm{~mm})$ dark red and brownish-yellow pseudo-hexagonal crystals, respectively. More commonly, however, they occur as very fine ( $<2 \mu \mathrm{m}$ wide) syntactic intergrowths in these large crystals (Fig. 9A). Rare synchysite-(Ce) $(<1$ vol. \%) occurs as very fine lamellae exsolved from parisite-(Ce). Both bastnäsite-(Ce) and parisite-(Ce) replaced brownish anhedral masses of ancylite-(Ce) $(<1$ vol. \%) (Fig. 9B) and cordylite- $(\mathrm{Ce})(<1$ vol.\%). Elsewhere, cordylite-(Ce) was replaced by ancylite-(Ce) (Fig. 9C). Monazite(Ce) (1 vol. \%) forms narrow prisms (10 $\mu \mathrm{m}$ long) that occur as inclusions in Dolomite 3, bastnäsite-(Ce), and parisite-(Ce) (Fig. 9D) and as aggregates near albite-rich fenite xenoliths, commonly in association with Dolomite 3 (Fig. 9E). The xenoliths contain traces of niobian rutile, which occurs as inclusions in veinlets of molybdenite and pyrite; these veinlets also rim Dolomite 2 in the vugs (Fig. 9F). Traces of thorite occur as inclusions in bastnäsite-(Ce) and vug-filling potassium feldspar. 
Taken together, these observations help establish a paragenesis for the mineralization (Fig. 10). Dolomite 3, barite, and sulfide minerals precipitated first as shown by their occurrence along the walls of the fractures and vugs, and were followed by precipitation of thorite and monazite-(Ce), later ancylite-(Ce) and cordylite-(Ce) and finally bastnäsite(Ce), parisite-(Ce), and synchysite-(Ce) (Fig. 9A-F). 

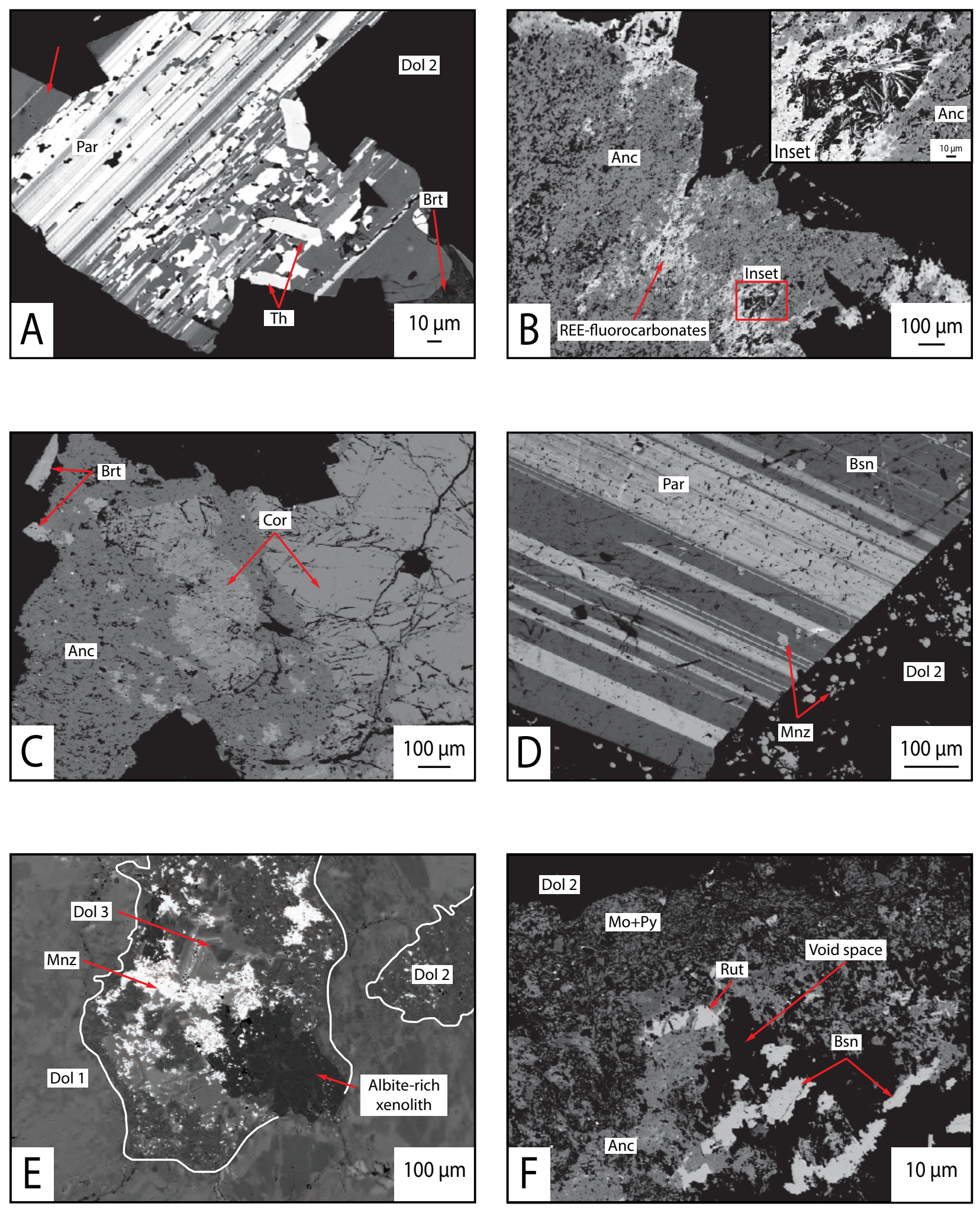
Fig. 9: A-F. Back-scattered electron images of dolomite carbonatite. A. Cross-section of a vein in which fractured Dolomite 2 was infilled by barite (Brt) and intergrowths of bastnäsite-(Ce) (Bsn) and parisite-(Ce) (Par) both containing inclusions of tabular thorite (Th). B. Cross-section of a fracture infilled by barite that was later replaced by ancylite-(Ce) (Anc). Inset of B.: Intergrowths of bastnäsite-(Ce) and parisite-(Ce) that replaced ancylite-(Ce). C. Cross-section of a vein of Dolomite 3 with inclusions of barite and cavity-lining cordylite-(Ce) (Cor) that was replaced by ancylite-(Ce) (Anc). D. Inclusions of monazite-(Ce) in intergrowths of bastnäsite-(Ce) and parisite-(Ce). E. Dolomite 1 altered to Dolomite 2 adjacent to a sodic fenite xenolith; an open space created by the alteration is infilled by Dolomite 3 , which is cut by monazite-(Ce). F. A fracture partially infilled by molybdenite (Mo) and pyrite (Py), followed by ancylite-(Ce) containing inclusions of rutile (Rut); bastnäsite-(Ce) occupies open space adjacent to the ancylite-(Ce). 


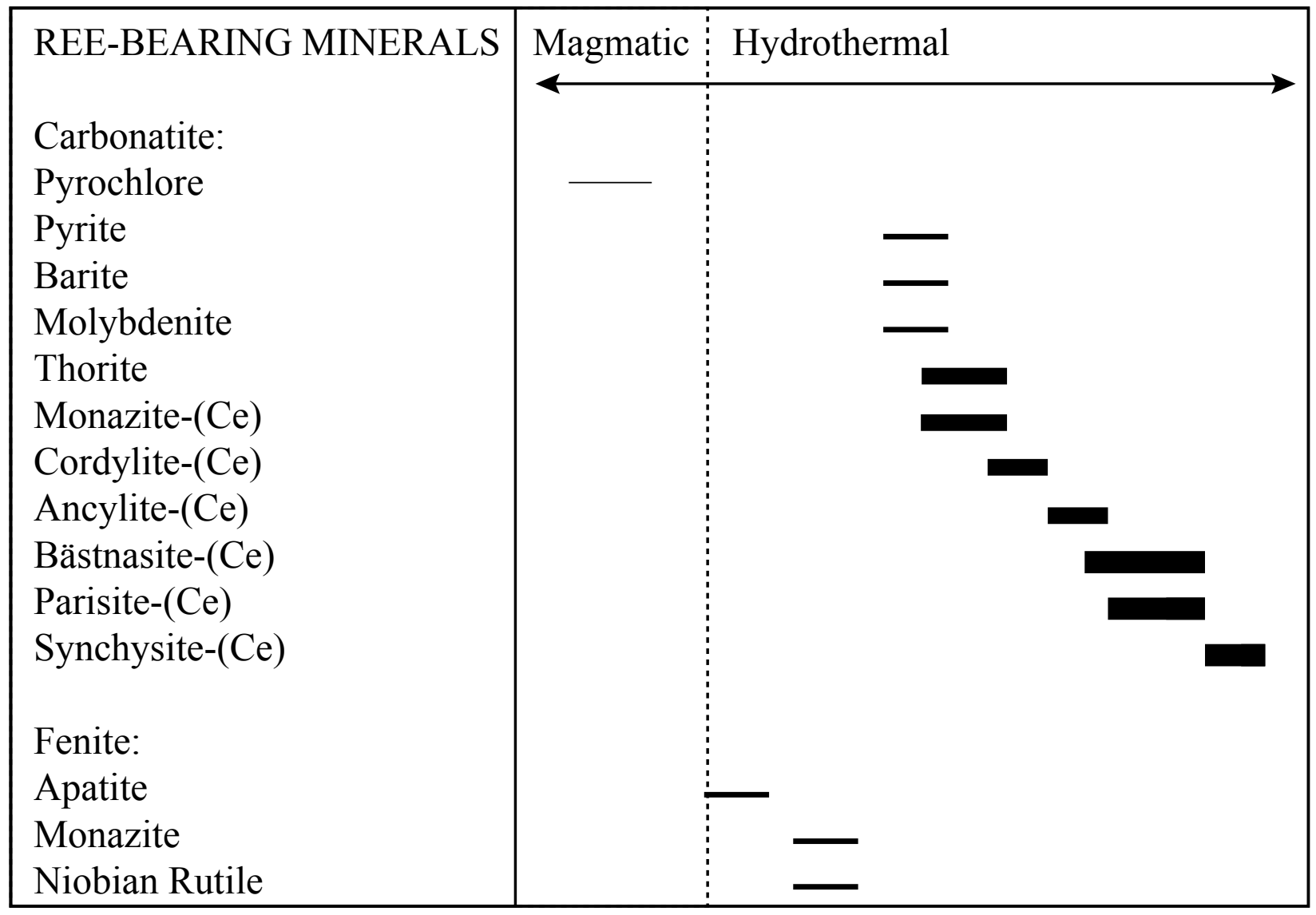

Fig. 10: Paragenetic diagram showing the order of crystallization of the main REE-bearing and associated minerals in the Wicheeda carbonatite. The line widths indicate the relative abundances of the minerals. 


\section{Carbonatite Composition}

A total of 19 samples of dolomite and calcite carbonatite from outcrop and drill core were analyzed for their major and trace element compositions using the methods described earlier (Methodology). The results are summarized in Table 1. According to the classification scheme of Gittins and Harmer (1997), carbonatites from the Wicheeda plug are mainly magnesio- and ferro-carbonatites, or ferruginous calcio-carbonatites with compositions near the $\mathrm{MgO}$-rich/CaO-poor corner of the corresponding field; the one sample of calcite carbonatite that was analyzed, as expected, classifies as calciocarbonatite (Fig. 11). The main non-volatile components of the calcite carbonatite are $\mathrm{CaO}$ (44.9 wt.\%), $\mathrm{MgO}$ (2.24 wt.\%), $\mathrm{FeO}$ (9.46 wt.\%), and $\mathrm{MnO}$ (0.83 wt.\%). There are also minor concentrations of $\mathrm{SrO}\left(1.59\right.$ wt.\%), $\mathrm{BaO}$ (0.32 wt.\%), $\mathrm{P}_{2} \mathrm{O}_{5}$ (2.46 wt.\%), Th (55 ppm), $\mathrm{Nb}(2500 \mathrm{ppm})$, and $\mathrm{REEE}(0.4 \mathrm{wt} . \%)$. The dolomite carbonatite ( $\mathrm{n}=18)$, by comparison, on average, contains less $\mathrm{CaO}$ (25.5 wt.\%), more $\mathrm{MgO}$ (12.45 wt.\%), more $\mathrm{Fe}_{2} \mathrm{O}_{3}$ (9.46 wt.\%), and more $\mathrm{MnO}(1.4$ wt.\%). The contents of $\mathrm{SrO}(0.16$ wt.\%), $\mathrm{BaO}$ (0.23 wt.\%), $\mathrm{P}_{2} \mathrm{O}_{5}(0.5$ wt.\%), and $\mathrm{Nb}(353 \mathrm{ppm})$ are much lower, whereas the Th and ¿REE contents are higher by an order of magnitude (564 ppm and 3.3 wt.\%, respectively). Significantly, the magnesio-carbonatites are slightly more enriched in the REE than the ferro-carbonatites (Fig. 12). The chondrite-normalized trace element profiles (Fig. 13) show that relative to the calcite carbonatite, the dolomite carbonatite samples are enriched in Th and the REE (mainly the LREE) and depleted in $\mathrm{Rb}, \mathrm{U}, \mathrm{Nb}$, and Ta. Both carbonatites have pronounced negative $\mathrm{U}$, Ta, and $\mathrm{Zr}$ anomalies. The chondrite-normalized REE profiles (Fig. 14) of the dolomite carbonatite show a much greater degree of LREE-enrichment $(\mathrm{La} / \mathrm{Lu}=6470)$ than the calcite carbonatite 
$(\mathrm{La} / \mathrm{Lu}=204)$. Indeed, the $\mathrm{Yb}$ and $\mathrm{Lu}$ contents of the calcite carbonatite correspond to the upper limit of their contents in the dolomite carbonatite. 


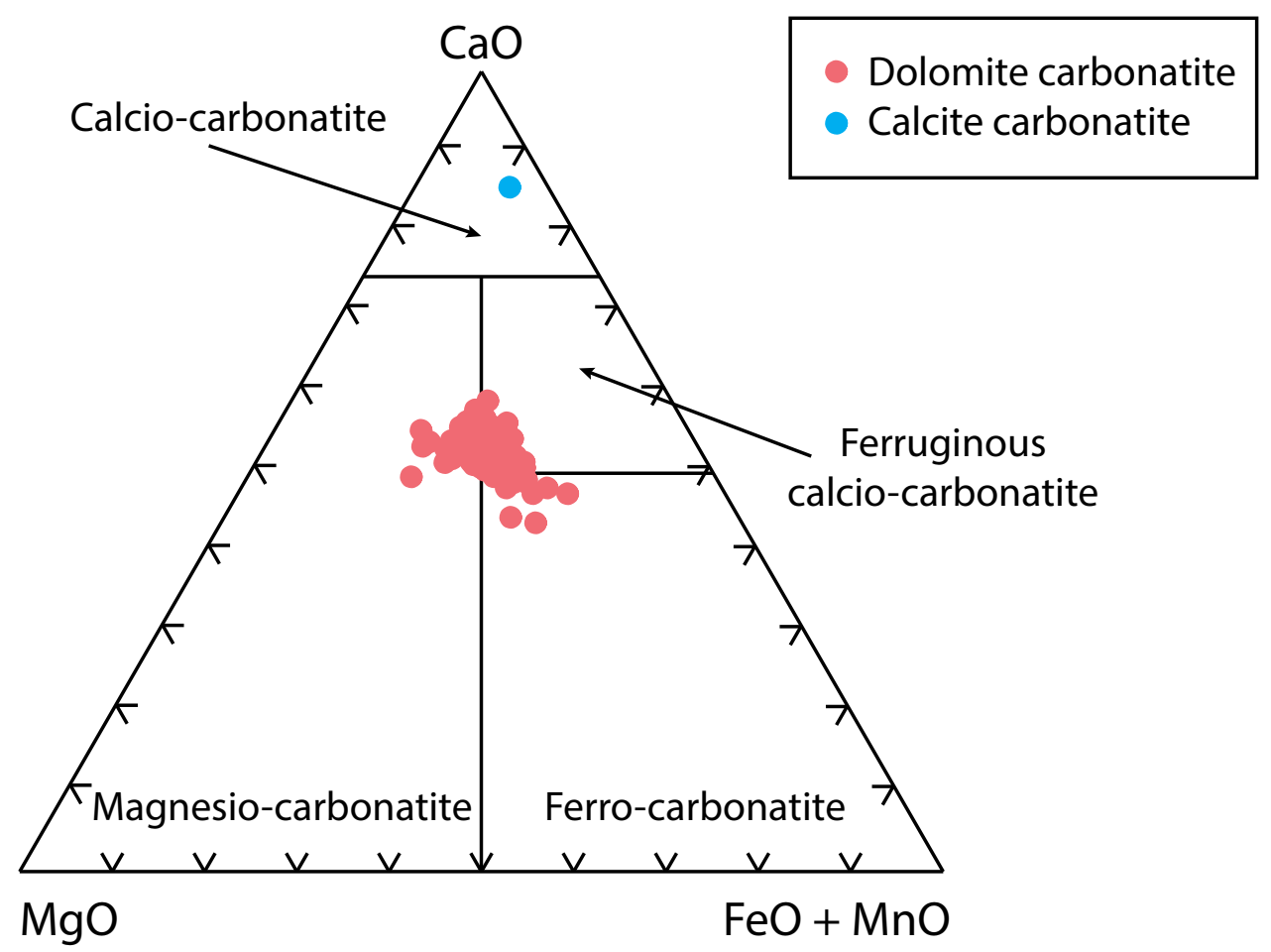

Fig. 11: The distribution of Wicheeda carbonatite compositions (molar proportions) on the $\mathrm{CaO}-\mathrm{MgO}-(\mathrm{FeO}+\mathrm{MnO})$ carbonatite classification diagram of Gittins and Harmer (1997). 


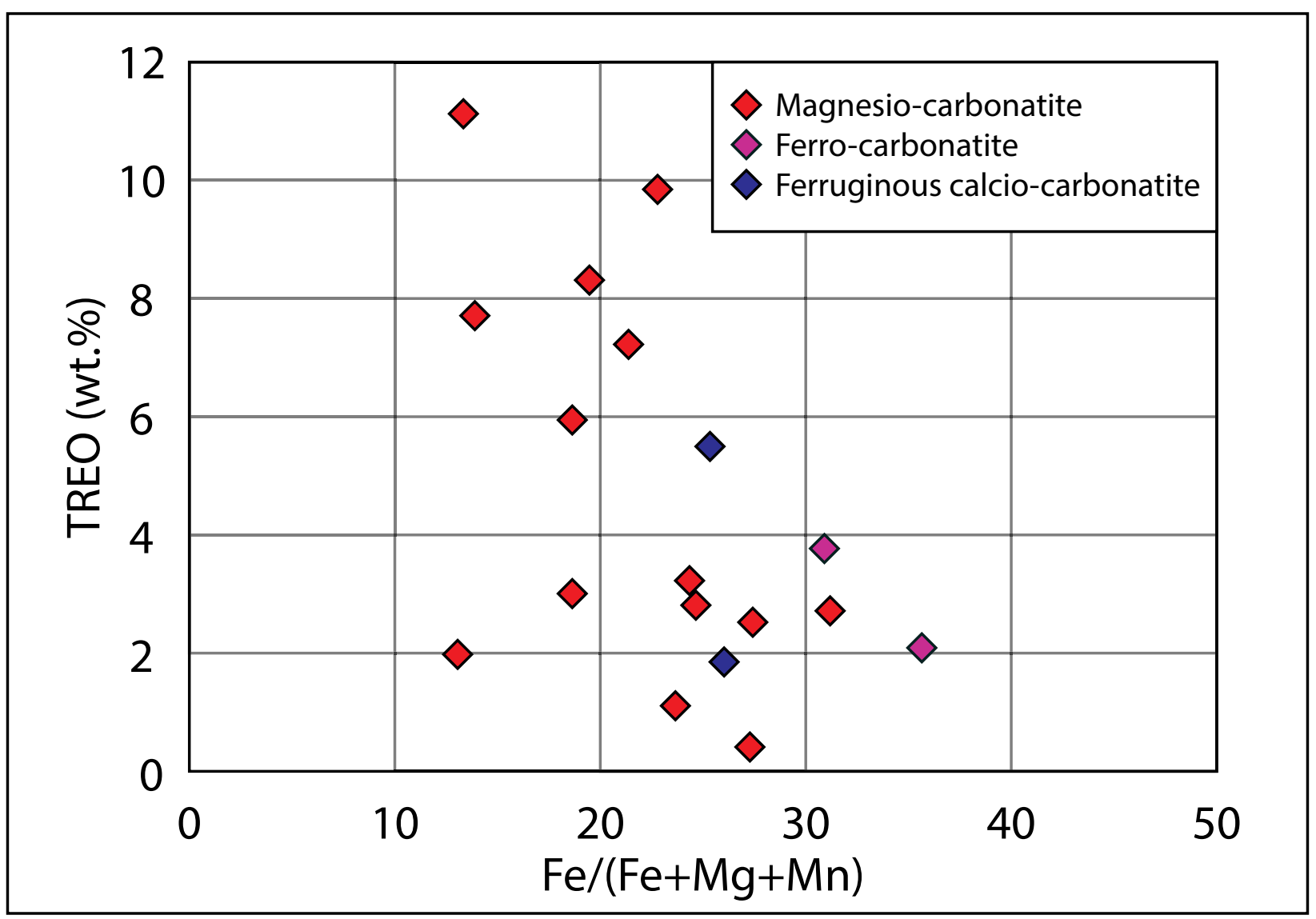

Fig. 12: The TREO content (wt.\%) of the Wicheeda dolomite carbonatites as a function of the bulk molar ratio, $\mathrm{Fe} /(\mathrm{Fe}+\mathrm{Mg}+\mathrm{Mn})$. 


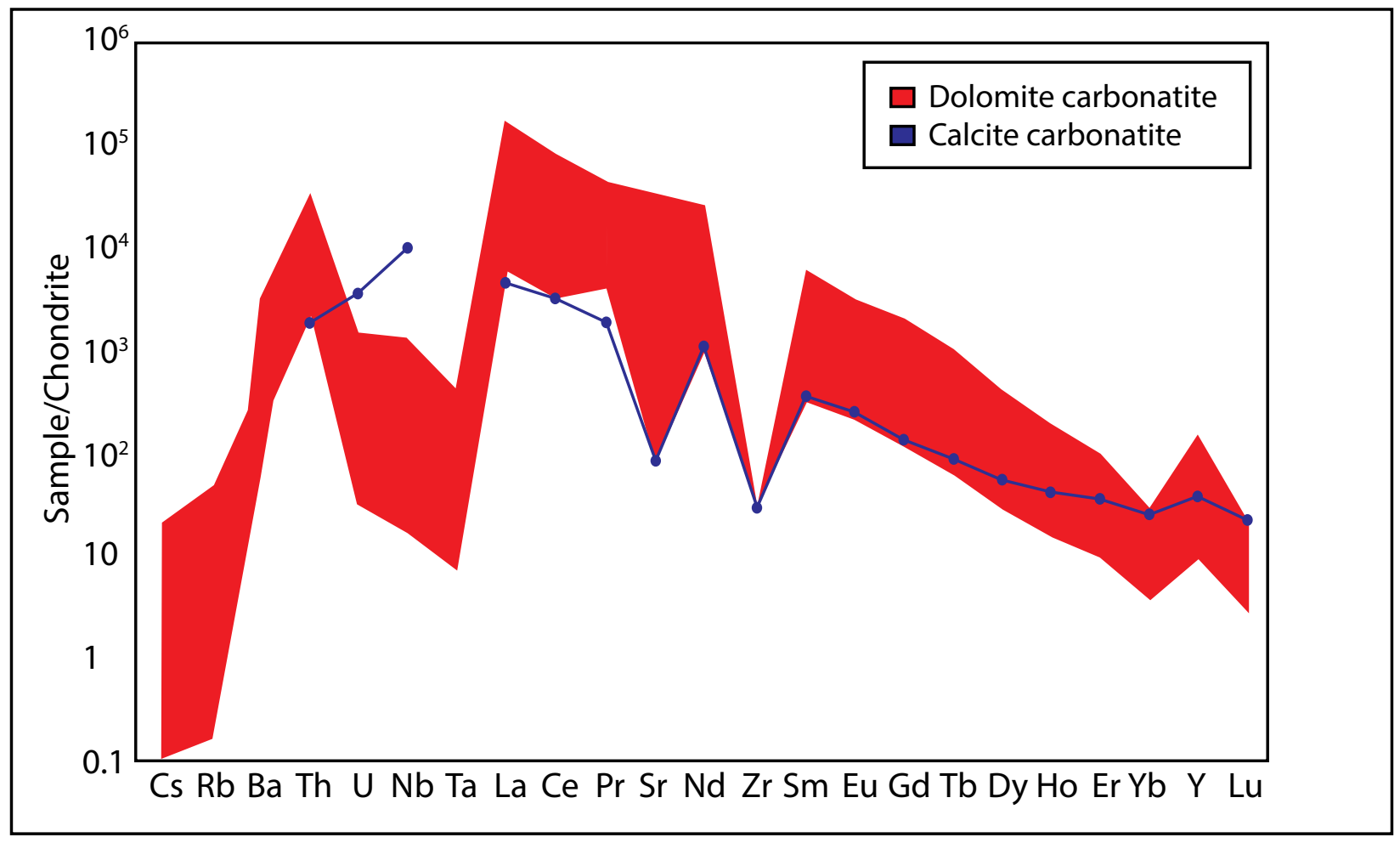

Fig. 13: A chondrite-normalized spider diagram illustrating the distribution of trace elements in the Wicheeda carbonatites. The data were normalized to CI chondrite (McDonough and Sun, 1995). 


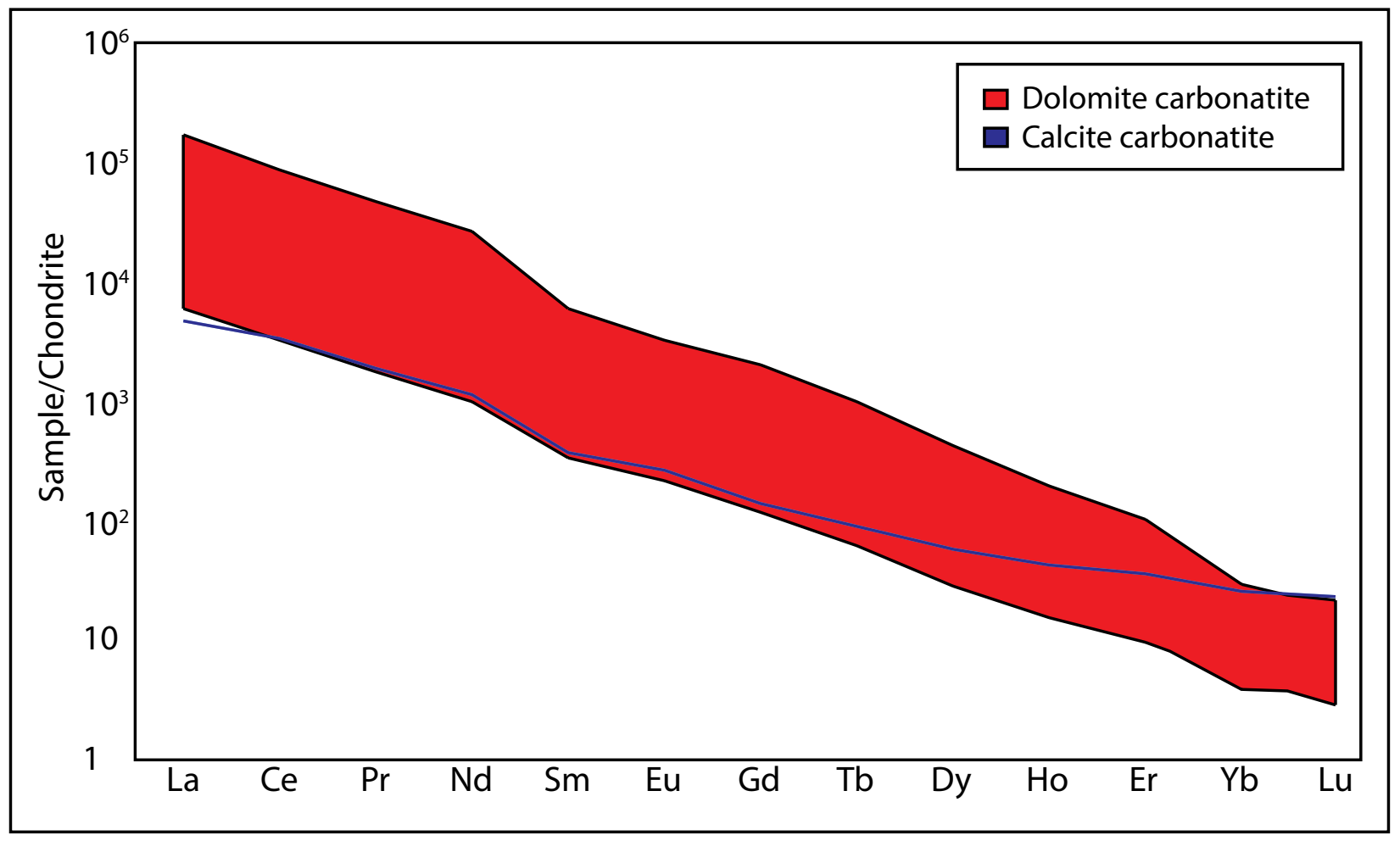

Fig. 14: A chondrite-normalized REE diagram for the Wicheeda dolomite carbonatite $(\mathrm{n}=18)$ and calcite carbonatite $(\mathrm{n}=1)$. The data were normalized to CI chondrite (McDonough and Sun, 1995). 


\section{Fenite Composition}

A small number of samples of potassic fenite (5) and sodic fenite (3) were analyzed for their bulk chemical composition in order to distinguish them chemically. As is evident from Figure 15, they are clearly distinguishable by their relative proportions of $\mathrm{Al}_{2} \mathrm{O}_{3}$, $\mathrm{Na}_{2} \mathrm{O}$ and $\mathrm{K}_{2} \mathrm{O}$, which confirms the mineralogical classification of these two fenite types. The potassic fenite contains an average of 30.4 wt.\% $\mathrm{SiO}_{2}, 8.9$ wt.\% $\mathrm{Al}_{2} \mathrm{O}_{3}, 3.1$ wt.\% $\mathrm{Na}_{2} \mathrm{O}, 2.2$ wt.\% $\mathrm{K}_{2} \mathrm{O}, 6.9$ wt.\% $\mathrm{Fe}_{2} \mathrm{O}_{3}, 5.1$ wt.\% $\mathrm{MgO}, 0.8$ wt.\% $\mathrm{P}_{2} \mathrm{O}_{5}, 0.81$ wt.\% SrO, and 0.14 wt. $\% \mathrm{BaO}$ (Table 1). The average $\mathrm{REEE}$ content is $0.34 \mathrm{wt} . \%$, the $\mathrm{Nb}$ content $473 \mathrm{ppm}$, and the $\mathrm{S}$ content $0.6 \mathrm{wt} . \%$. The F content is below its limit of detection.

On average, the sodic fenite contains more $\mathrm{SiO}_{2}$ (36.1 wt.\%), $\mathrm{Na}_{2} \mathrm{O}$ (5.8 wt.\%) and $\mathrm{SrO}$ (0.42 wt.\%) than the potassic fenite and less $\mathrm{Al}_{2} \mathrm{O}_{3}$ (8.1 wt.\%), $\mathrm{K}_{2} \mathrm{O}$ (0.7 wt.\%), $\mathrm{Fe}_{2} \mathrm{O}_{3}$ (5.2 wt.\%), and $\mathrm{MgO}$ (3.9 wt.\%) (Table 1). It also has very much lower $\mathrm{REE}$ (0.08 wt.\%), and $\mathrm{Nb}(82 \mathrm{ppm})$ contents than the latter. The $\mathrm{P}_{2} \mathrm{O}_{5}(0.83$ wt.\%) and $\mathrm{BaO}(0.10$ wt.\%) contents are similar to those of the potassic fenite, however, the S content (0.4 wt.\%) is slightly lower. The F content is below the detection limit.

Although the carbonatites and fenites have quite different major element compositions, their trace element composition profiles are relatively similar (Figs. 13, and 16). Both the potassic and sodic fenite are enriched in $\mathrm{Th}, \mathrm{Nb}, \mathrm{REE}$, and $\mathrm{Y}$ and have negative $\mathrm{U}, \mathrm{Ta}$, and $\mathrm{Zr}$ anomalies; the Kechika metasedimentary rocks are depleted in $\mathrm{Nb}$ and enriched in $\mathrm{U}$. The potassic fenite samples generally have higher $\mathrm{Th}, \mathrm{U}, \mathrm{Nb}$ and $\mathrm{REE}$ contents than the sodic fenite (Figs. 16 and 17). Moreover, the $\mathrm{Yb}$ and Lu contents of the most REE- 
enriched potassic fenites are greater than those of any of the rocks in the study area (Table 1). Fresh Kechika Group argillaceous limestone has a lower REE content than either of the fenite types and a lower $\mathrm{La} / \mathrm{Lu}$ ratio. 


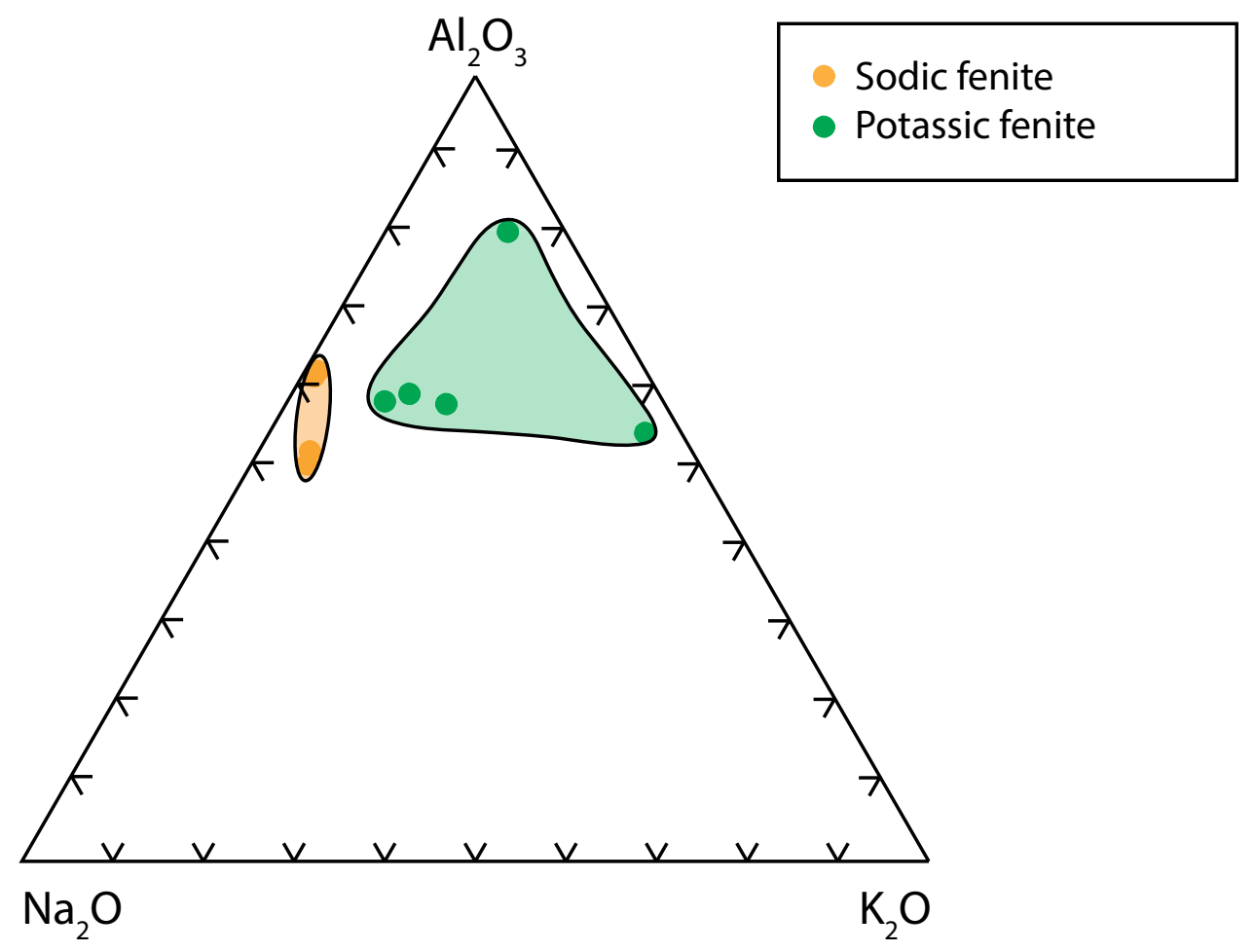

Fig. 15: A plot showing the compositions (wt. \%) of potassic and sodic fenites in terms of the components, $\mathrm{Al}_{2} \mathrm{O}_{3}, \mathrm{Na}_{2} \mathrm{O}$, and $\mathrm{K}_{2} \mathrm{O}$. 


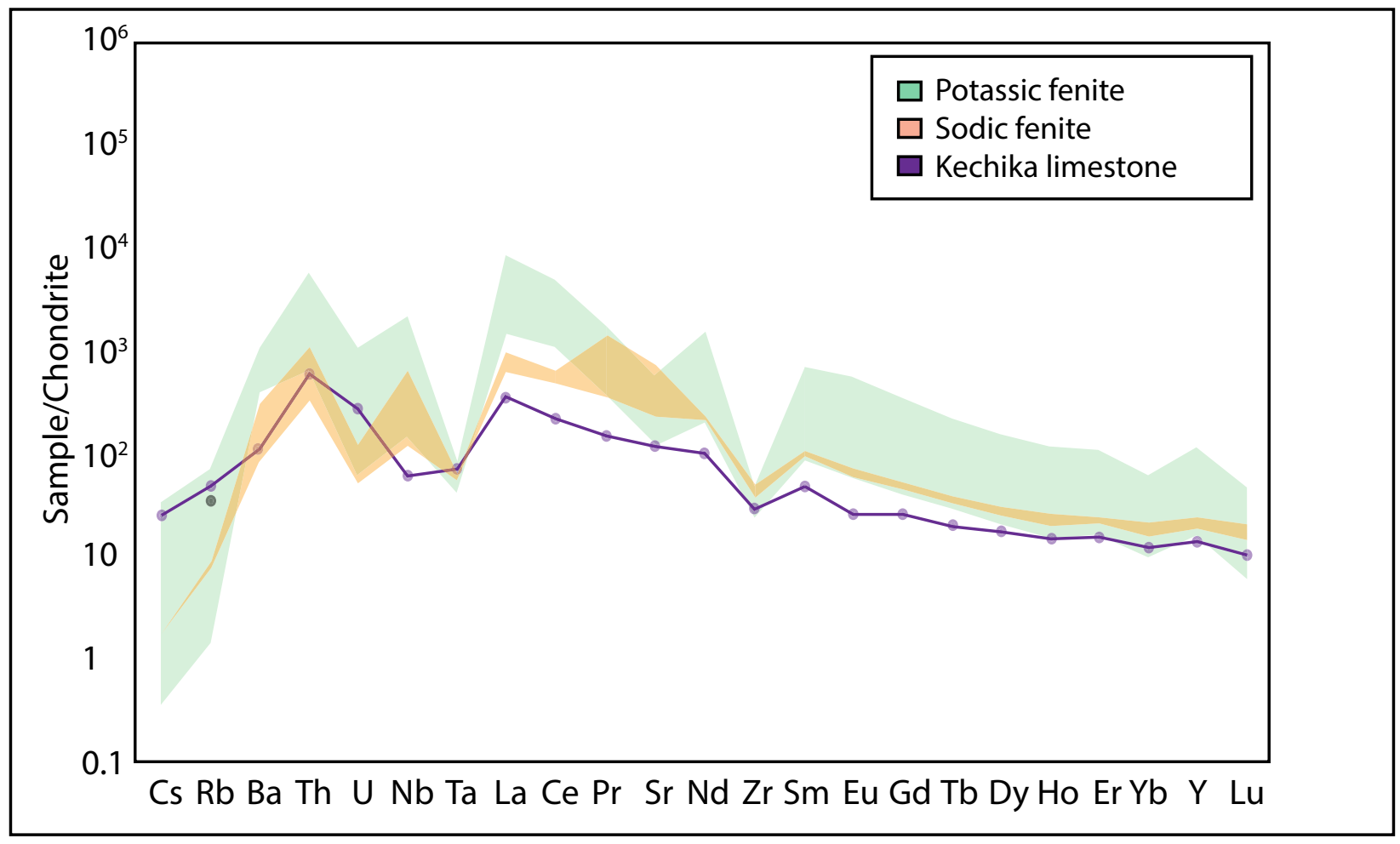

Fig. 16: A chondrite-normalized spider diagram illustrating the distribution of trace elements in the Wicheeda fenites and Kechika argillaceous limestone. 


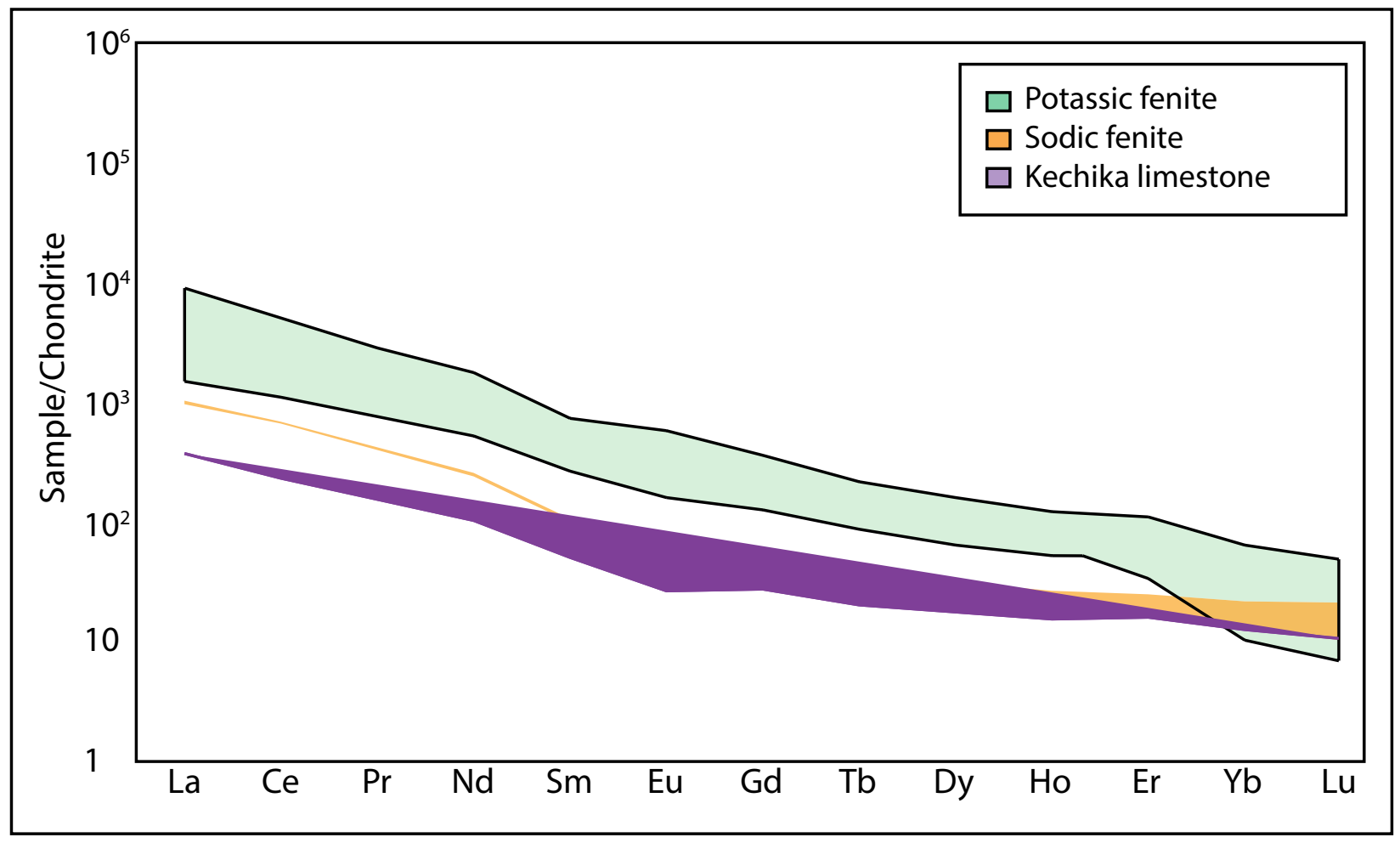

Fig. 17: A chondrite-normalized REE diagram for the potassic fenite $(n=6)$, sodic fenite $(n=3)$, and Kechika argillaceous limestone $(\mathrm{n}=1)$. The data were normalized to CI chondrite (McDonough and Sun, 1995). 


\section{Bulk distribution of the REE}

As will be evident from the preceding sections, the potentially economic REE mineralization is concentrated in the carbonatites and particularly the dolomite carbonatite. This is borne out by Figure 18A, which shows the total REE content (TREO) of the different carbonatite types and fenites compiled from company drill core assay data and an assumed economic cutoff grade of 1 wt.\% TREO. Elevated niobium concentrations $(>500 \mathrm{ppm})$ were observed mainly in the calcite carbonatite and potassic fenite (Fig. 18B). As the REE are present dominantly as REE fluorocarbonate minerals and phosphates, we have also evaluated their distribution in the dolomite carbonatite as a function of the contents of fluorine and phosphorous (Fig. 19A and 19B; Table 1). The importance of fluorine to the REE mineralization is clearly demonstrated by the strong linear correlation of F and LREE bulk rock contents (Fig. 19A). Significantly, and in contrast to the behavior of the LREE with fluorine, the data for LREE versus phosphorous, indicate the presence of two populations, one with a low P content $(<0.5$ wt.\%) and another with a relatively elevated P content (0.8-1.7 wt.\%). In further contrast to the data for F, the LREE content in both the populations appears to be independent of the phosphorous content. The likely explanation for these observations is that in some samples the REE mineralization was largely in the form of REE fluorocarbonate and SrREE carbonate minerals (low $\mathrm{P}$ population), whereas in others it also comprised appreciable concentrations of monazite-(Ce) (high $\mathrm{P}$ population); some of the samples of the high $\mathrm{P}$ population also have elevated concentrations of alkalis and $\mathrm{Al}$, and may therefore contain small proportions of apatite-bearing fenite xenoliths not detected during sampling (see earlier descriptions of rock units). 

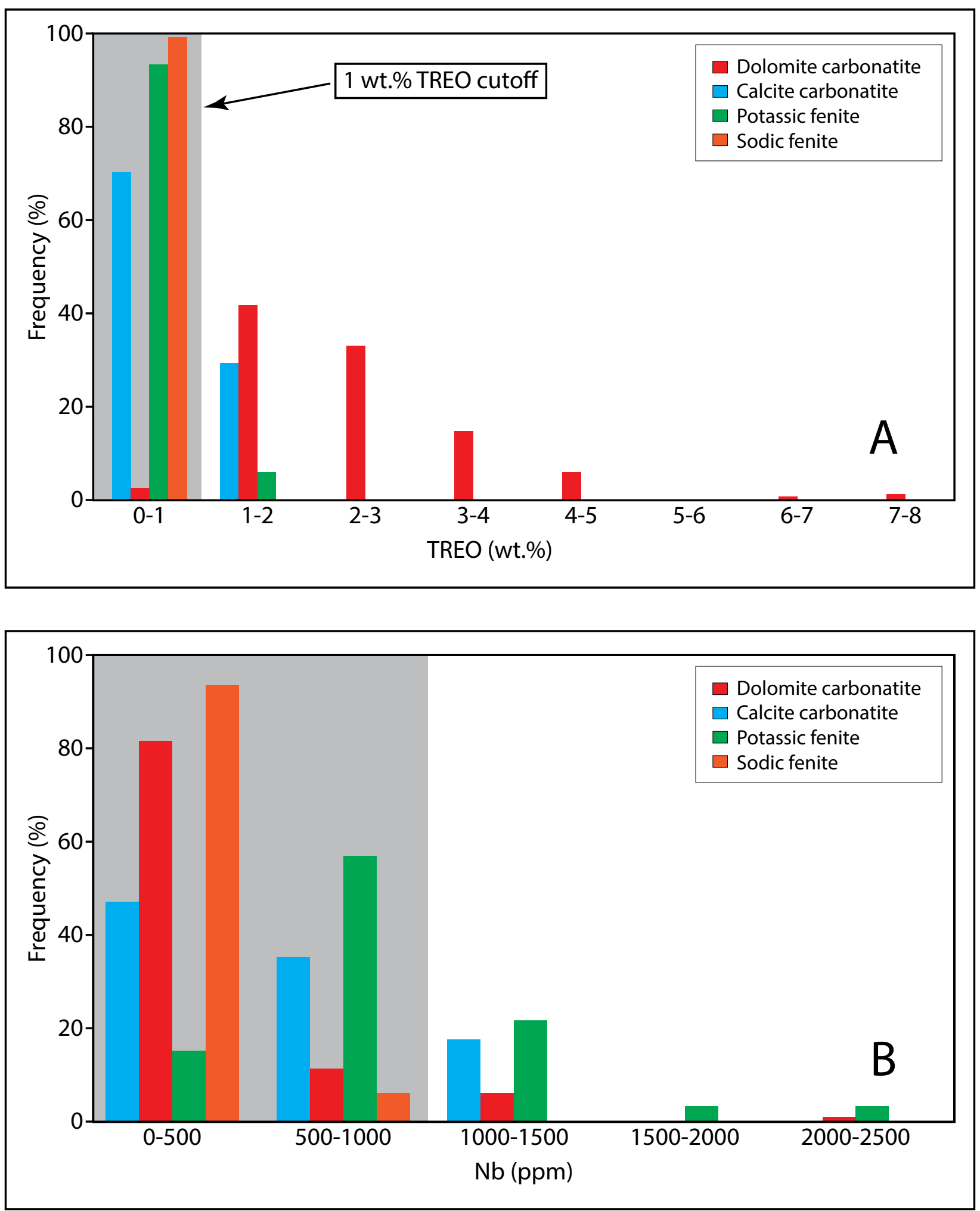

Fig. 18: A. A bar graph showing the total REE content in weight percent of the carbonatites and fenites. B. A bar graph showing the total niobium content in weight percent of the carbonatites and fenites. The graphs were constructed from company drill core assay data (Lane, 2009; 2010). 

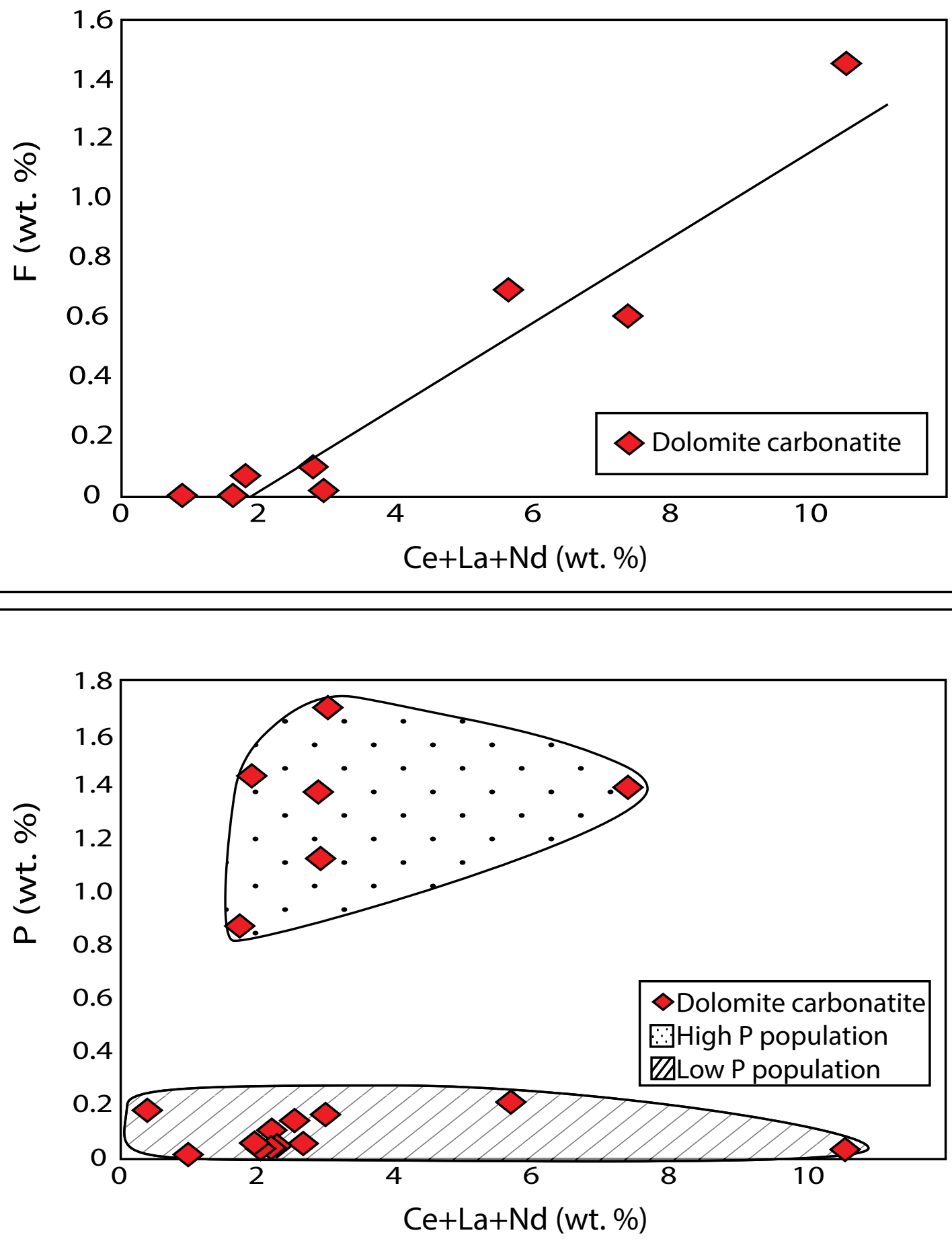

Fig. 19: A. The concentration of $\mathrm{Ce}+\mathrm{La}+\mathrm{Nd}($ wt.\%) as a function of $\mathrm{F}$ concentration (wt. \%) in the dolomite carbonatite. The trend line illustrates the linear relationship between $\mathrm{F}$ and LREE contents. B. The concentration of $\mathrm{Ce}+\mathrm{La}+\mathrm{Nd}$ (wt.\%) as a function of $\mathrm{P}$ concentration in the dolomite carbonatite. The data indicate the presence of a high $\mathrm{P}$ population (representing fluorapatite-bearing fenite xenoliths), and a low $\mathrm{P}$ population (xenolith-free). 


\section{Mineral Chemistry}

\section{Carbonates}

Electron microprobe analyses were conducted on crystals of Dolomite 1, 2, and 3 in samples collected from the main intrusion (WI-11-02, WI-11-07, WI-11-09, and WI-1112) and the carbonatite outcrop northeast of the main intrusion (WI-13-11). The average compositions of Dolomite 1 and 2 are quite similar (Table 3). Dolomite 1 has average $\mathrm{CaO}, \mathrm{FeO}, \mathrm{MgO}, \mathrm{MnO}$ contents of 29.6, 18.4, 5.1, and 0.6 wt.\%, respectively, and Dolomite 2 has average concentrations for these oxides of 29.6, 17.0, 6.7, and 0.8 wt.\%, respectively. However, $\mathrm{FeO}: \mathrm{MgO}$ ratios of Dolomite 1 are on average lower and have a more limited range (average $\mathrm{XFe}_{\mathrm{Dol} 1}=0.24$; Fig. 20A) than those of Dolomite 2 (average $\mathrm{XFe}_{\mathrm{Dol} 2}=0.31$; Fig. 20A) 2. Dolomite 3 has a similar $\mathrm{CaO}$ content $(29.33$ wt.\%) to Dolomite 1 and Dolomite 2, but on average, it contains less MgO (14.69 wt.\%), and more $\mathrm{FeO}(9.26$ wt.\%) and $\mathrm{MnO}$ (1.14 wt.\%). Moreover, it is progressively enriched in $\mathrm{FeO}$ and $\mathrm{MnO}$ inwards from its contacts with Dolomite 2 or from the walls of the cavities (in which it commonly occurs) to their centers (Figure 20B and C). The three dolomite types display a distribution of $\mathrm{CaO}, \mathrm{FeO}$ and $\mathrm{MgO}$ contents that broadly mimics that of the corresponding bulk rock, although the latter are displaced to higher $\mathrm{FeO}$ and higher $\mathrm{CaO}$ (Table 1, Table 3; Figure 21). The Ba and Sr contents of both Dolomite 1 and Dolomite 2 are below the corresponding detection limits. By comparison, Dolomite 3 contains elevated $\mathrm{SrO}(0.16 \mathrm{wt} . \%)$. 
Table 3: Average composition of carbonates in the Wicheeda carbonatite.

\begin{tabular}{|c|c|c|c|c|c|}
\hline \multirow{2}{*}{\multicolumn{2}{|c|}{$\begin{array}{c}\text { Mineral } \\
\text { Rock type } \\
\text { Classification }\end{array}$}} & \multicolumn{3}{|c|}{$\begin{array}{c}\text { Dolomite } \\
\text { Dolomite carbonatite }\end{array}$} & \multirow{3}{*}{$\begin{array}{c}\text { Calcite } \\
\text { Calcite carbonatite } \\
\mathrm{n}=18 \\
\end{array}$} \\
\hline & & \multirow{2}{*}{$\begin{array}{l}\text { Dol } 1 \\
\mathrm{n}=28 \\
29.55\end{array}$} & \multirow{2}{*}{$\begin{array}{l}\text { Dol } 2 \\
\mathrm{n}=82 \\
29.57\end{array}$} & \multirow{3}{*}{$\begin{array}{l}\text { Dol } 3 \\
\mathrm{n}=44 \\
29.33\end{array}$} & \\
\hline & & & & & \\
\hline $\mathrm{CaO}$ & wt. $\%$ & & & & 53.36 \\
\hline $\mathrm{MgO}$ & & 18.39 & 17.00 & 14.69 & 0.36 \\
\hline $\mathrm{FeO}$ & & 5.13 & 6.65 & 9.26 & 1.84 \\
\hline $\mathrm{MnO}$ & & 0.57 & 0.83 & 1.14 & 1.19 \\
\hline $\mathrm{SrO}$ & & b.1. & b.1. & 0.16 & b.l. \\
\hline $\mathrm{CO}_{2}$ & & 46.24 & 46.01 & 45.87 & 43.15 \\
\hline Total & & 99.88 & 100.06 & 100.45 & 99.90 \\
\hline Cations & & $\mathrm{O}=6$ & & & $\mathrm{O}=3$ \\
\hline $\mathrm{Ca}$ & apfu & 1.01 & 1.01 & 1.00 & 0.95 \\
\hline $\mathrm{Mg}$ & & 0.86 & 0.81 & 0.71 & 0.01 \\
\hline $\mathrm{Fe}^{2+}$ & & 0.14 & 0.18 & 0.25 & 0.03 \\
\hline Mn & & 0.02 & 0.02 & 0.03 & 0.02 \\
\hline $\mathrm{Sr}$ & & 0.00 & 0.00 & 0.00 & 0.00 \\
\hline $\mathrm{C}$ & & 1.99 & 2.00 & 2.01 & 0.98 \\
\hline Total & & 4.01 & 4.00 & 3.99 & 1.99 \\
\hline
\end{tabular}

Notes: b.l. Below detection limits for oxides (wt.\%), as noted in Appendix D 

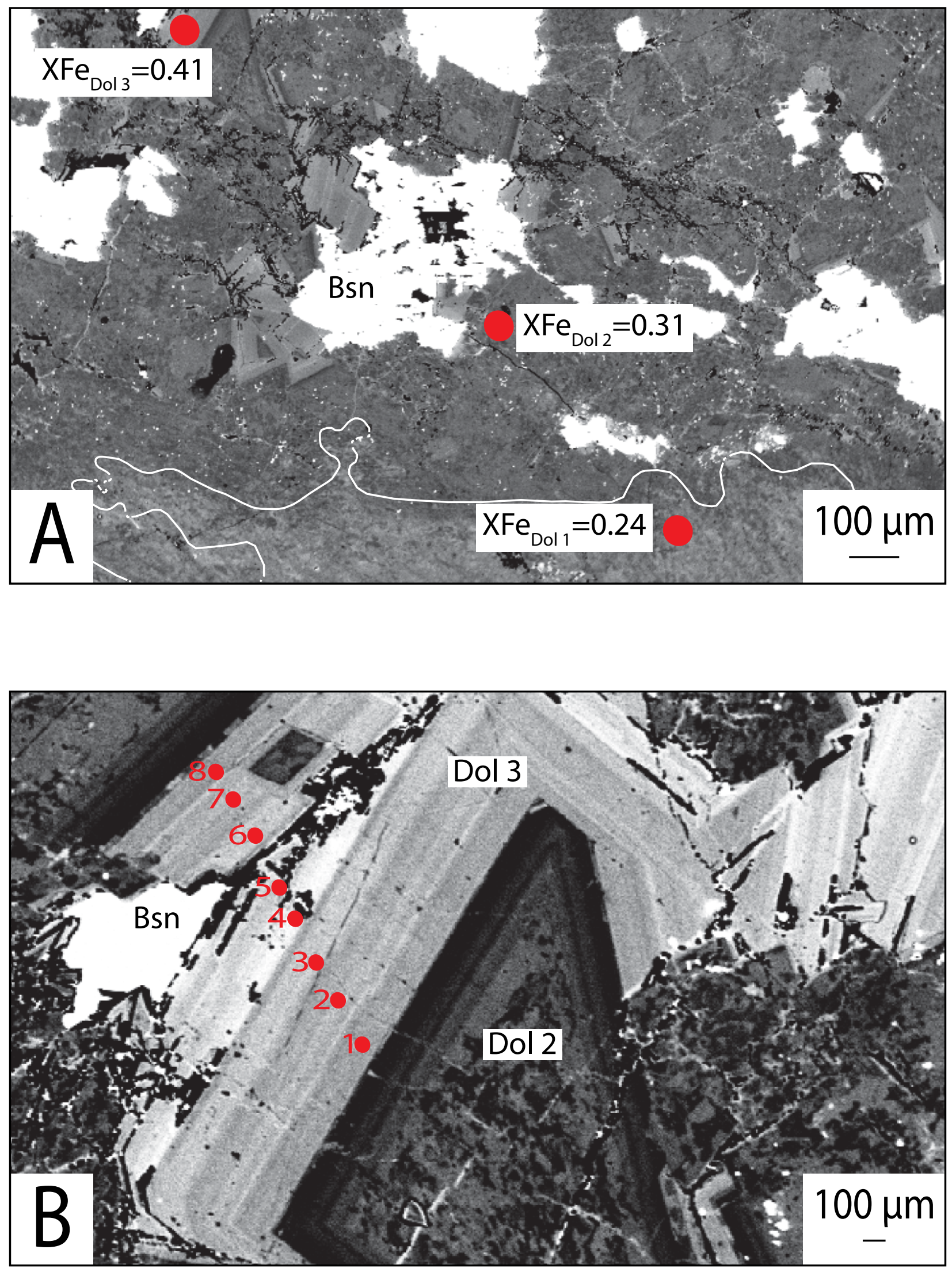


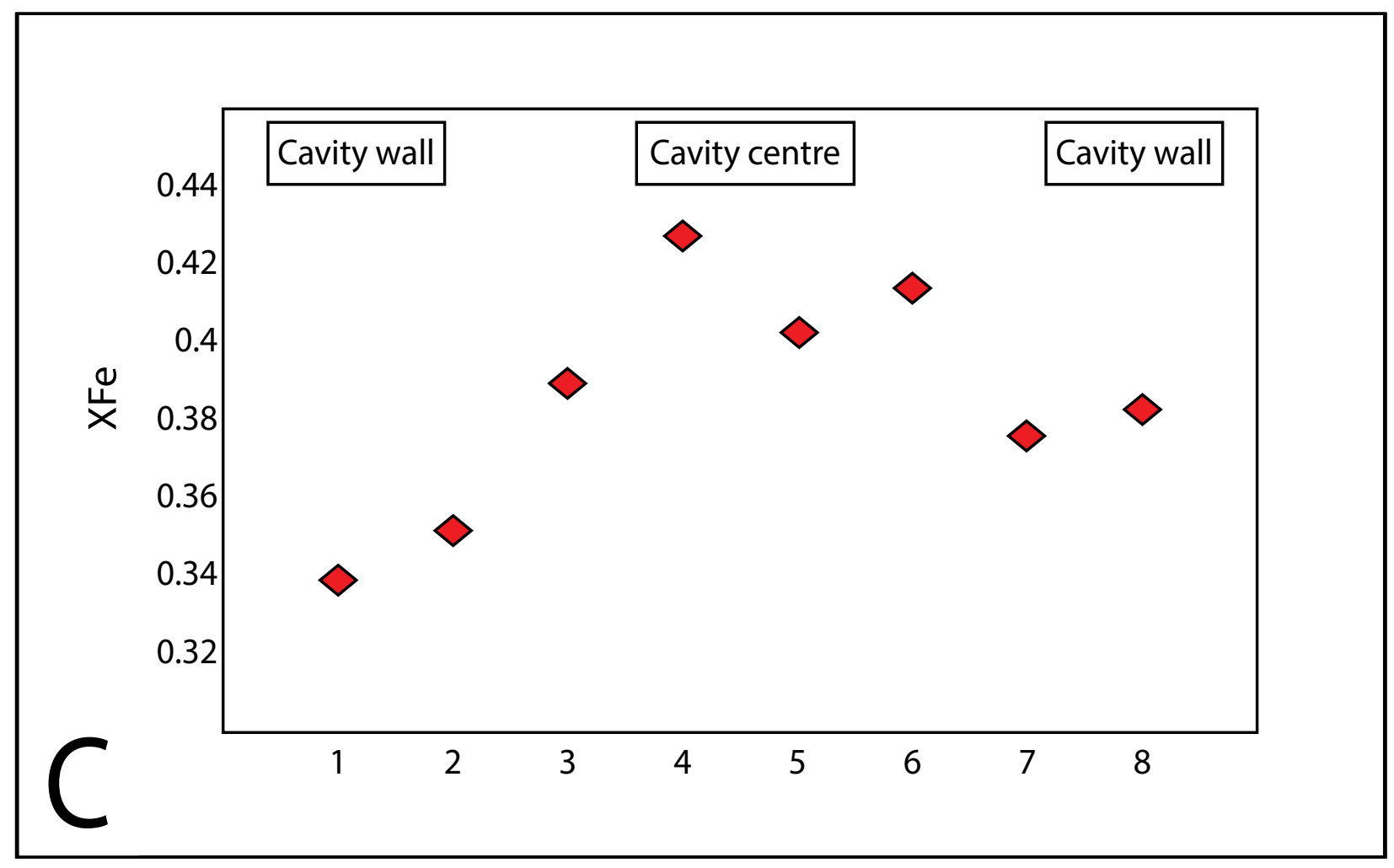

Fig. 20: A. Back-scattered electron image of dolomite carbonatite (WI-13-11). Iron-poor Dolomite 1 (light grey) was altered to iron-rich Dolomite 2 (dark grey) near a fracture partially infilled by compositionally zoned Dolomite 3 and bastnäsite-(Ce) (Bsn). The three red filled circles show the locations of analyses of Dolomite 1, Dolomite 2 and Dolomite 3 and the adjacent text boxes the corresponding mole fraction of $\mathrm{Fe}(\mathrm{XFe}) \mathrm{B}$. Back-scattered electron image showing the location of an electron-microprobe traverse across Dolomite 3 from a cavity wall to the cavity centre. $\mathrm{C}$. The $\mathrm{XFe}$ value for each of the locations in Dolomite 3 indicated in $\mathrm{B}$. 


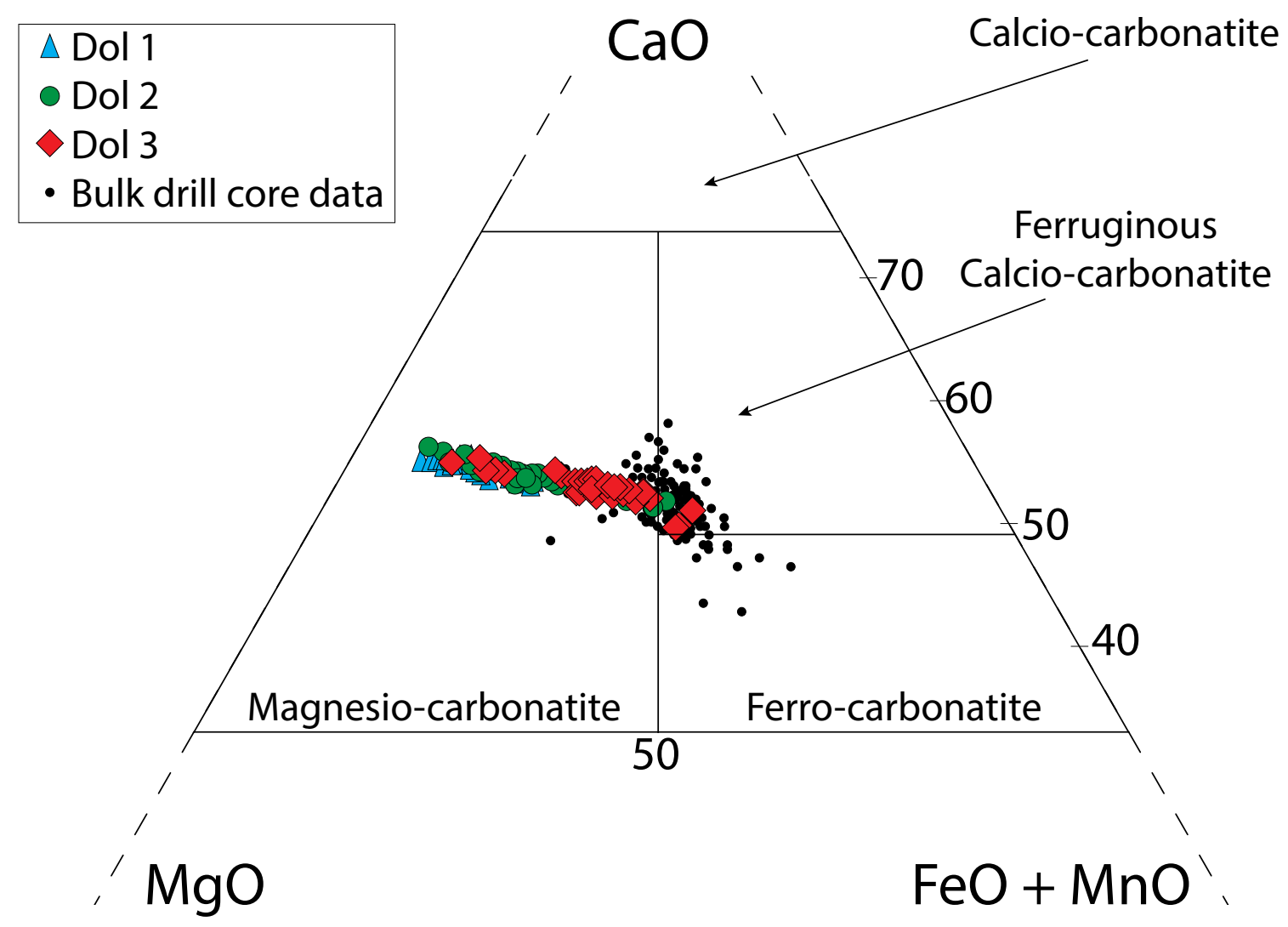

Fig. 21: The composition of Dolomite 1, Dolomite 2 and Dolomite 3 in terms of the components $\mathrm{CaO}, \mathrm{MgO}$, and $\mathrm{FeO}$ (molar proportions). The bulk rock compositions and fields of the carbonatite types of Gittins and Harmer (1997) are shown for comparison (see main text for further detail). 
Calcite grains were analyzed in a single sample of calcite carbonatite. This mineral is close to the end-member composition with 53.4 wt. $\% \mathrm{CaO}$ and 43.2 wt. $\% \mathrm{CO}_{2}$. There are minor concentrations of $\mathrm{MgO}$ (0.36 wt.\%), $\mathrm{FeO}$ (1.84 wt.\%), $\mathrm{Mn}$ (1.19 wt.\%), $\mathrm{SrO}$ (0.03 wt.\%). Barium is below its limit of detection.

\section{Silicates}

Mica

The compositions of micas from the dolomite and calcite carbonatites (Table 4) identify them as members of the phlogopite-biotite series (e.g., Fig. 22). Mica in the dolomite carbonatite has a composition ranging from 54 to $60 \%$ of the phlogopite component and appreciable contents of $\mathrm{TiO}_{2}(1.87$ wt.\%) and $\mathrm{F}(2.9$ wt.\%), whereas mica in the calcite carbonatite contains between 75 and $78 \%$ of the biotite component. In addition to its higher biotite content, mica in the calcite carbonatite contains more $\mathrm{TiO}_{2}(3.74$ wt.\%) and less F (0.19 wt.\%) than in the dolomite carbonatite.

The major element chemistry of the mica in potassic and sodic fenite is very similar (Table 4). There is from 52 to $62 \%$ phlogopite and appreciable $\mathrm{TiO}_{2}(1.9$ wt.\%) and $\mathrm{F}$ (2.8 wt.\%). Compositionally, this mica is similar to mica in the dolomite carbonatite (Fig. 22). 


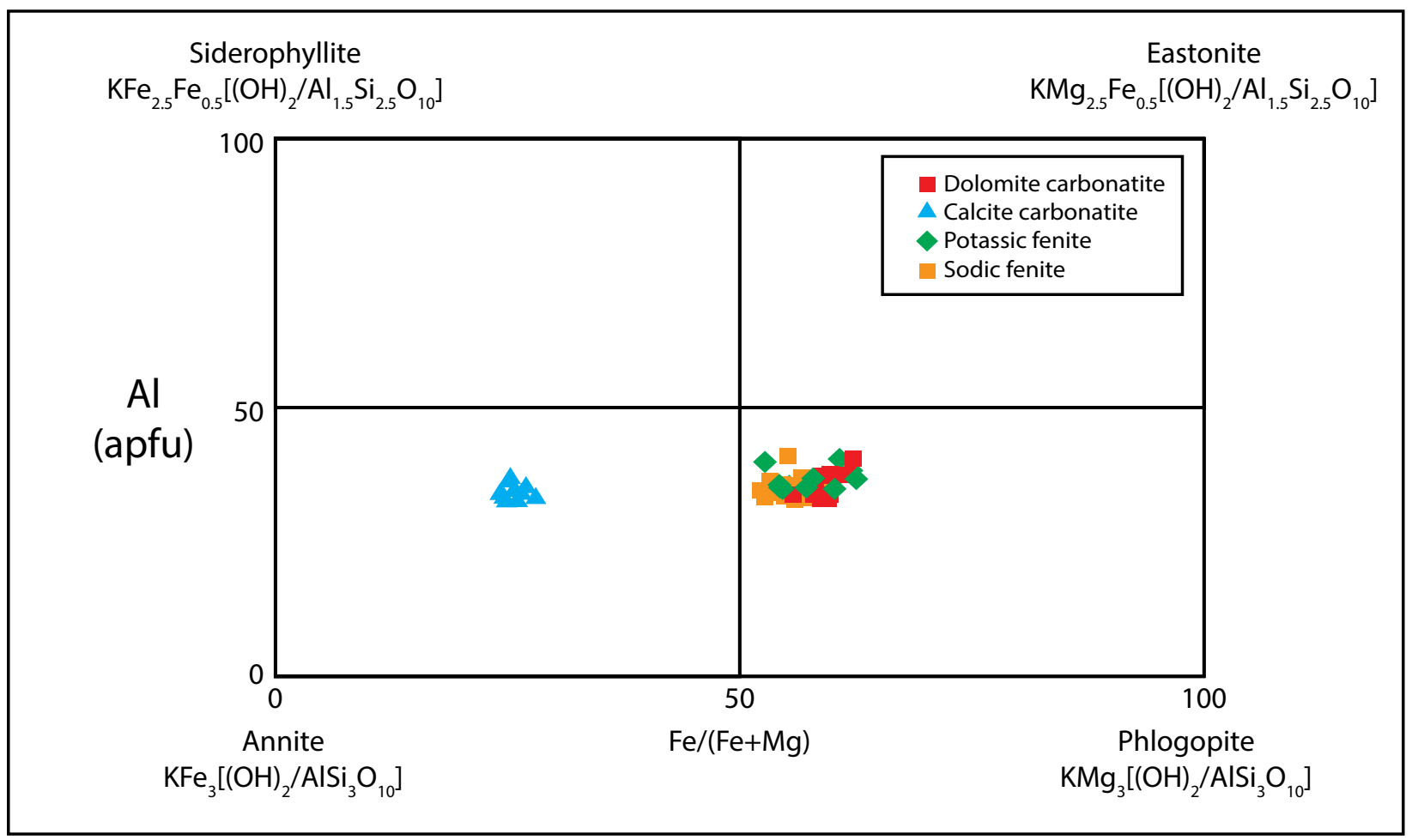

Fig. 22: The composition of mica in the dolomite carbonatite, calcite carbonatite, potassic fenite, and sodic fenite in terms of the end member components, siderophyllite, eastonite, phlogopite, and annite after Rieder et al. (1998). 


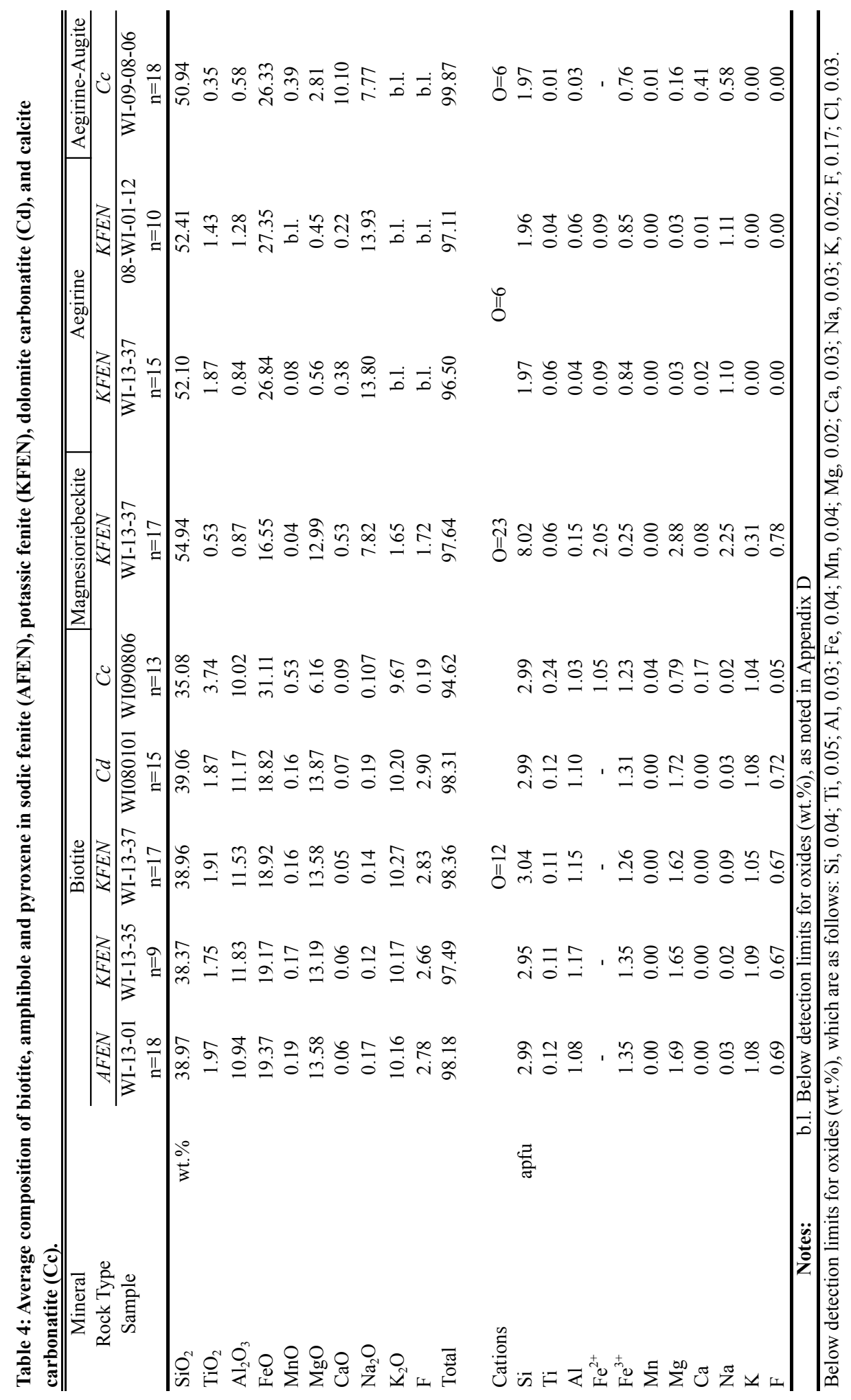




\section{Amphibole}

Amphibole was only observed in one sample (WI-13-37), a potassic fenite, in which it replaced aegirine. Its composition (Table 4) classifies it as magnesioriebeckite (Fig. 23; Hawthorne et al., 2012).

\section{Pyroxene}

Pyroxene was observed in two samples of potassic fenite (WI-13-37, 08-WI-01-12) and one sample of calcite carbonatite (WI-09-08-06). In the potassic fenite, the pyroxene classifies as aegirine on the sodic pyroxene ternary diagram (e.g., Fig. 24) of Morimoto et al. (1988). It contains from 70 to $74 \%$ of the aegirine end-member and from 0.5 to $3.8 \%$ of the jadeite end-member, and is characterized by a high content of $\mathrm{Na}_{2} \mathrm{O}$ (13.85 wt.\%), and low $\mathrm{Al}_{2} \mathrm{O}_{3}$ (1 wt.\%), and $\mathrm{CaO}(0.5$ wt.\%) contents (Table 4). Its manganese content is below the detection limit and the $\mathrm{TiO}_{2}$ content is comparable to that in the mica (1.69 wt.\%). The pyroxene in the calcite carbonatite contains more calcium (10.1 wt.\% CaO), magnesium (2.81 wt.\% MgO), and manganese (0.39 wt.\% MnO), and less $\mathrm{Na}_{2} \mathrm{O}$ (7.77 wt.\%) and $\mathrm{TiO}_{2}(0.35$ wt.\%). Its composition defines a linear trend straddling the boundary between aegirine and aegirine-augite (Fig. 24). 


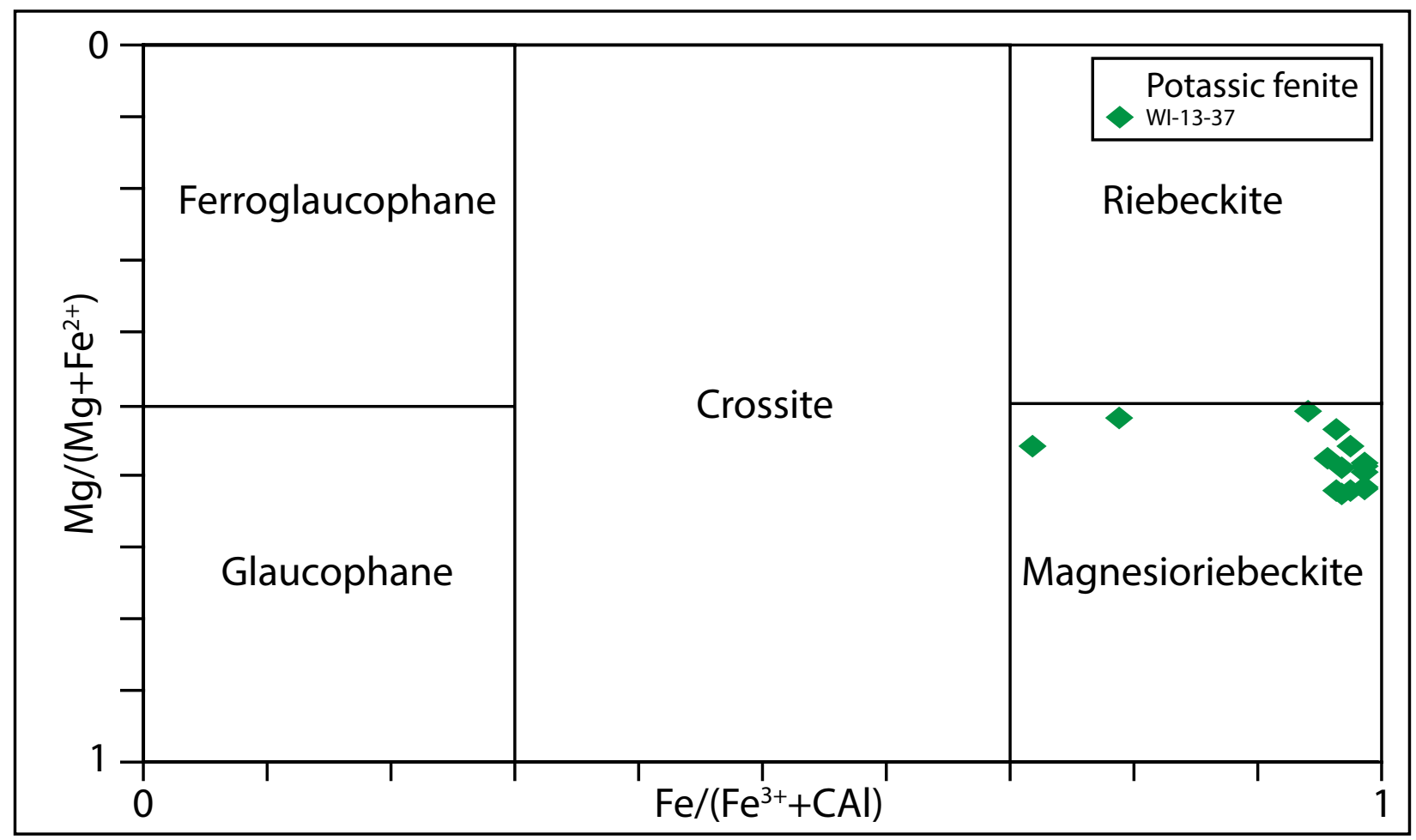

Fig. 23: The composition of amphibole in the potassic fenite represented on the classification diagram of Hawthorne et al. (2012). 


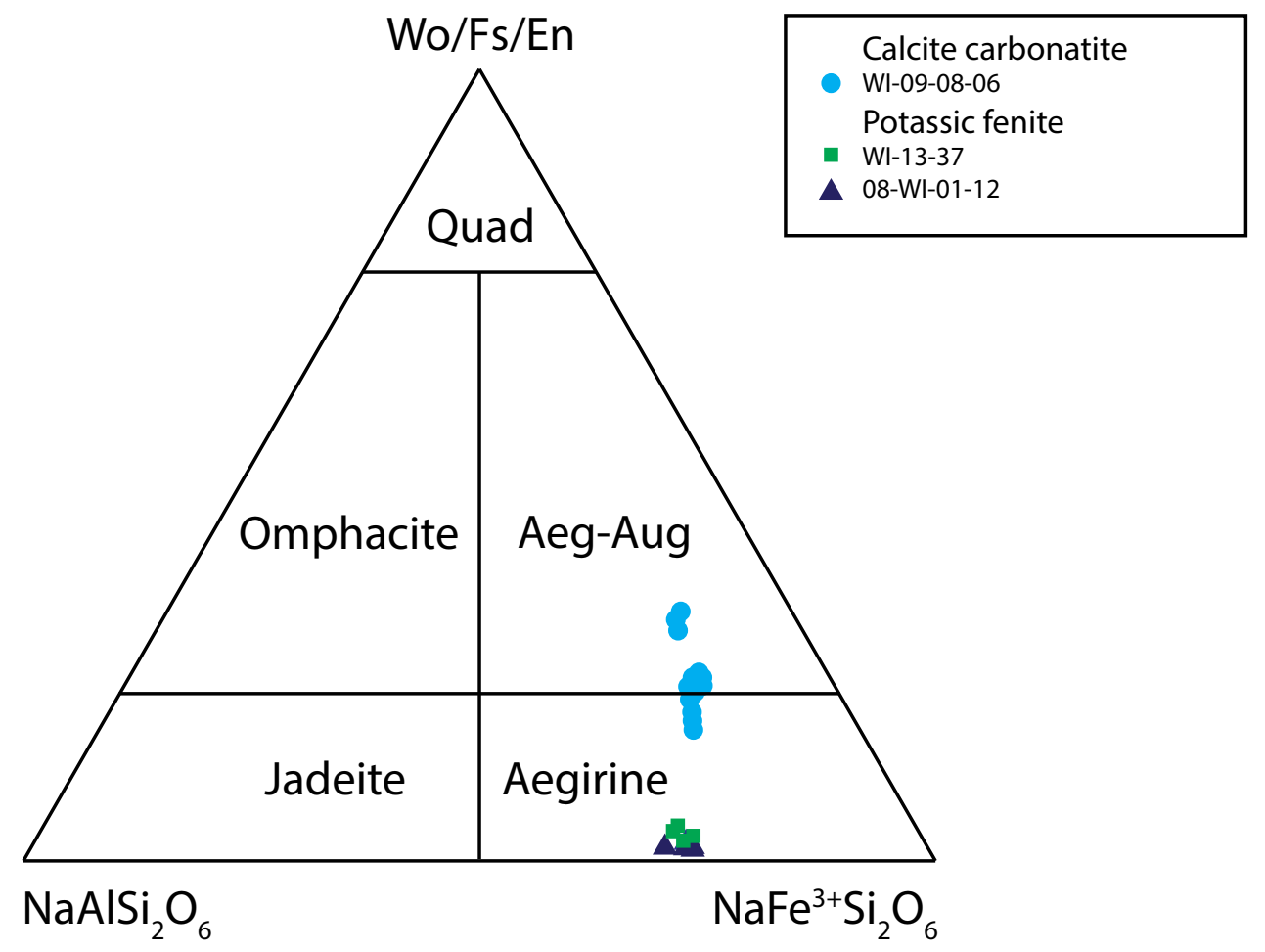

Fig. 24: The composition of pyroxene in calcite carbonatite and potassic fenite represented on the classification diagram of Morimoto et al. (1988). Wo/Fs/En refer to wollastonite $\left(\mathrm{CaSiO}_{3}\right)$, forsterite $\left(\mathrm{Mg}_{2} \mathrm{SiO}_{4}\right)$, and enstatite $\left(\mathrm{FeSiO}_{3}\right)$, respectively. 


\section{Alkali feldspar}

Alkali feldspar is observed in both the carbonatites and fenites. It occurs as potassium feldspar $\left(\mathrm{Or}_{98}\right)$ in the dolomite carbonatite and contains minor $\mathrm{BaO}(2.77 \mathrm{wt} . \%)$; $\mathrm{SrO}$ and $\mathrm{Rb}_{2} \mathrm{O}$ are at or below their detection limits (Table 5). The calcite carbonatite only contains albite $\left(\mathrm{Ab}_{92}\right.$ to $\left.\mathrm{Ab} b_{99}\right) ; \mathrm{BaO}, \mathrm{SrO}$, and $\mathrm{Rb}_{2} \mathrm{O}$ concentrations are at or below the detection limits.

Feldspars in the potassic and sodic fenite are near the potassium feldspar and albite endmembers on an anorthite-albite-orthoclase ternary diagram, respectively (Table 5, Fig. 25). Feldspar in the potassic fenite contains both potassium feldspar, which has a composition of $\mathrm{Or}_{78-99}$, and albite $\left(\mathrm{Ab}_{90-99}\right)$. The albite has low concentrations of $\mathrm{FeO}$ (0.4 wt.\%) and $\mathrm{CaO}\left(0.32\right.$ wt.\%). The $\mathrm{SrO}$ and $\mathrm{Rb}_{2} \mathrm{O}$ contents of the feldspars are at or below their detection limits; minor concentrations of $\mathrm{BaO}$ were observed in the albite (0.68 wt.\%). In the sodic fenite, the feldspar is exclusively albite with a much narrower range in composition than in the potassic fenite $\left(\mathrm{Ab}_{98}\right.$ to $\left.\mathrm{Ab}_{99}\right)$ and has low concentrations of $\mathrm{FeO}$ (up to 1.6 wt.\%) and $\mathrm{CaO}$ (up to 1.5 wt.\%). The $\mathrm{BaO}, \mathrm{SrO}$, and $\mathrm{Rb}_{2} \mathrm{O}$ contents are at or below their detection limits. 
Table 5: Average composition of alkali feldspar in sodic fenite (AFEN), potassic fenite (KFEN), dolomite carbonatite (Cd), and calcite carbonatite (Cc).

\begin{tabular}{|c|c|c|c|c|c|c|c|c|c|c|}
\hline \multirow{3}{*}{$\begin{array}{c}\text { Mineral } \\
\text { Rock Type } \\
\text { Sample }\end{array}$} & & \multicolumn{9}{|c|}{ Feldspar } \\
\hline & & $A F E N$ & KFEN & KFEN & KFEN & KFEN & KFEN & KFEN & $C c$ & $C d$ \\
\hline & & $\begin{array}{c}\text { WI-13-01 } \\
n=9\end{array}$ & $\begin{array}{c}\text { WI-13-09 } \\
n=30\end{array}$ & $\begin{array}{c}\text { WI-13-09 } \\
n=10\end{array}$ & $\begin{array}{c}\text { WI-13-55 } \\
n=17\end{array}$ & $\begin{array}{c}\text { WI-13-55 } \\
n=21\end{array}$ & $\begin{array}{c}\text { WI-13-57 } \\
n=11\end{array}$ & $\begin{array}{c}\text { WI-13-57 } \\
\mathrm{n}=11\end{array}$ & $\begin{array}{c}\text { WI-13-38 } \\
\mathrm{n}=15\end{array}$ & $\begin{array}{c}\text { WI090902 } \\
n=7\end{array}$ \\
\hline$\overline{\mathrm{SiO}_{2}}$ & wt. $\%$ & 68.40 & 67.48 & 64.45 & 66.09 & 65.87 & 68.38 & 63.15 & 67.70 & 62.79 \\
\hline $\mathrm{Al}_{2} \mathrm{O}_{3}$ & & 19.65 & 19.29 & 18.43 & 19.51 & 18.82 & 19.08 & 19.23 & 19.44 & 19.40 \\
\hline $\mathrm{Na}_{2} \mathrm{O}$ & & 11.37 & 11.29 & 0.50 & 6.81 & 4.23 & 11.18 & 0.36 & 11.35 & 0.35 \\
\hline $\mathrm{K}_{2} \mathrm{O}$ & & 0.09 & 0.08 & 15.89 & 0.14 & 10.46 & 0.06 & 15.56 & 0.07 & 15.09 \\
\hline $\mathrm{BaO}$ & & b.l. & b.l. & b.l. & 1.16 & 0.10 & b.1. & 0.21 & b.1. & 2.77 \\
\hline $\mathrm{CaO}$ & & 0.04 & 0.32 & 0.09 & 0.12 & 0.17 & b.1. & 0.11 & 0.51 & b.1. \\
\hline $\mathrm{FeO}$ & & b.1. & 0.44 & 0.07 & 0.11 & 0.07 & 0.08 & 0.15 & b.1. & 0.10 \\
\hline Total & & 99.63 & 98.98 & 99.52 & 100.15 & 99.78 & 98.87 & 98.83 & 99.18 & 100.57 \\
\hline Cations & & & & & $\mathrm{O}=8$ & & & & & \\
\hline $\mathrm{Si}$ & apfu & 2.99 & 2.96 & 2.91 & 2.99 & 2.95 & 3.10 & 2.95 & 2.98 & 2.90 \\
\hline $\mathrm{Al}$ & & 1.01 & 1.00 & 0.98 & 1.01 & 1.03 & 0.90 & 1.07 & 1.01 & 1.06 \\
\hline $\mathrm{Na}$ & & 0.97 & 0.96 & 0.04 & 0.96 & 0.05 & 0.87 & 0.03 & 0.97 & 0.03 \\
\hline $\mathrm{K}$ & & 0.00 & 0.00 & 0.91 & 0.01 & 0.91 & 0.00 & 0.93 & 0.00 & 0.90 \\
\hline $\mathrm{Ba}$ & & 0.00 & 0.00 & 0.00 & 0.00 & 0.02 & 0.00 & 0.00 & 0.00 & 0.04 \\
\hline $\mathrm{Ca}$ & & 0.00 & 0.09 & 0.22 & 0.01 & 0.01 & 0.00 & 0.01 & 0.03 & 0.00 \\
\hline $\mathrm{Fe}$ & & 0.00 & 0.02 & 0.01 & 0.00 & 0.04 & 0.00 & 0.01 & 0.00 & 0.10 \\
\hline
\end{tabular}

Notes:

b.1. Below detection limits for oxides (wt.\%), as noted in Appendix D 


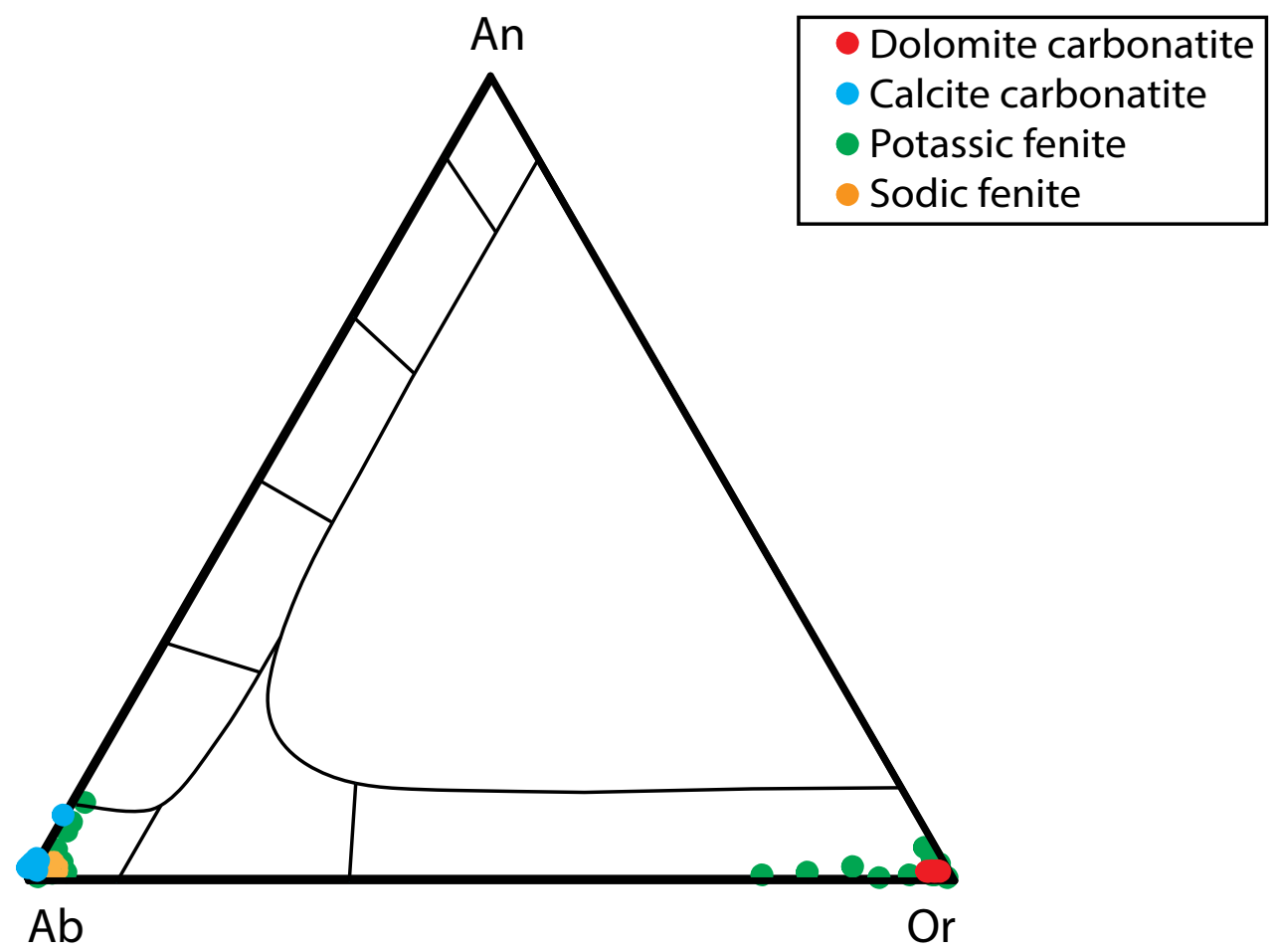

Fig. 25: The composition of feldspar in sodic fenite, potassic fenite, and calcite carbonatite in terms of the components, anorthite, albite and orthoclase. 


\section{REE and HFSE Minerals}

The REE are concentrated mainly in the dolomite carbonatite as REE-fluorocarbonate minerals, Sr-REE-carbonate minerals, and monazite-(Ce); they are also concentrated to a much smaller degree as monazite-(Ce) and apatite in the fenites. Niobium is present as pyrochlore in the calcite carbonatite and mainly as niobian rutile in the dolomite carbonatite. Thorite is the main thorium-bearing mineral, however, minor concentrations of Th are also present in ancylite-(Ce) and monazite-(Ce).

\section{REE-carbonate minerals}

The REE-fluorocarbonate and Sr-REE-carbonate minerals are the most abundant REEbearing minerals in the Wicheeda Carbonatite. They comprise (in order of decreasing abundance) bastnäsite-(Ce), parisite-(Ce), ancylite-(Ce), cordylite-(Ce), and synchysite(Ce). Cordylite-(Ce) (Ba-REE-fluorocarbonate) replaced barite in fractures and vugs containing Dolomite 3, and was later replaced by ancylite-(Ce) (Sr-REEfluorocarbonate), and in turn by bastnäsite-(Ce), parisite-(Ce), and synchysite-(Ce); synchysite-(Ce) replaced parisite-(Ce). The results of electron microprobe analyses of the REE-fluorocarbonate and Sr-REE-carbonate minerals are summarized in Table 6. 
Table 6: Average composition of REE-fluorocarbonate and REE-carbonate minerals in dolomite carbonatite.

\begin{tabular}{|c|c|c|c|c|c|c|}
\hline Mineral & & $\begin{array}{c}\text { Bastnäsite-(Ce) } \\
n=43\end{array}$ & $\begin{array}{c}\text { Parisite-(Ce) } \\
n=41\end{array}$ & $\begin{array}{c}\text { Synchysite-(Ce) } \\
n=4\end{array}$ & $\begin{array}{c}\text { Cordylite-(Ce) } \\
n=8\end{array}$ & $\begin{array}{c}\text { Ancylite-(Ce) } \\
\mathrm{n}=8\end{array}$ \\
\hline$\overline{\mathrm{CaO}}$ & wt. $\%$ & 0.25 & 10.21 & 18.98 & 2.73 & 2.45 \\
\hline $\mathrm{La}_{2} \mathrm{O}_{3}$ & & 28.19 & 21.07 & 18.13 & 15.99 & 18.67 \\
\hline $\mathrm{Ce}_{2} \mathrm{O}_{3}$ & & 35.52 & 29.14 & 23.21 & 22.08 & 24.93 \\
\hline $\mathrm{Pr}_{2} \mathrm{O}_{3}$ & & 2.91 & 2.71 & 1.95 & 0.44 & 2.18 \\
\hline $\mathrm{Nd}_{2} \mathrm{O}_{3}$ & & 7.25 & 7.44 & 5.10 & 3.62 & 5.38 \\
\hline $\mathrm{Sm}_{2} \mathrm{O}_{3}$ & & b.1. & 0.25 & 0.38 & 0.14 & b.1. \\
\hline $\mathrm{Gd}_{2} \mathrm{O}_{3}$ & & 0.18 & 0.30 & 0.16 & b.1. & 0.21 \\
\hline $\mathrm{Y}_{2} \mathrm{O}_{3}$ & & 0.06 & 0.12 & 0.08 & b.1. & 0.09 \\
\hline $\mathrm{CO}_{2}{ }^{1}$ & & 16.91 & 21.05 & 25.58 & 29.39 & 20.87 \\
\hline $\mathrm{SrO}$ & & 0.04 & 0.30 & 0.53 & 2.68 & 14.92 \\
\hline $\mathrm{BaO}$ & & 0.04 & 0.04 & 0.05 & 19.76 & 0.60 \\
\hline $\mathrm{ThO}_{2}$ & & 0.19 & 0.36 & 0.23 & b.1. & 1.67 \\
\hline $\mathrm{SiO}_{2}$ & & 0.06 & 0.04 & 0.06 & 0.02 & 0.51 \\
\hline $\mathrm{Na}_{2} \mathrm{O}$ & & b.1. & b.1. & b.1. & 3.25 & b.1. \\
\hline $\mathrm{Al}_{2} \mathrm{O}_{3}$ & & 0.02 & 0.03 & b.1. & 0.16 & 0.02 \\
\hline $\mathrm{UO}_{2}$ & & 0.01 & 0.01 & 0.01 & 0.01 & 0.02 \\
\hline $\mathrm{F}$ & & 8.22 & 6.88 & 5.53 & 2.72 & 0.86 \\
\hline $\mathrm{Cl}$ & & b.1. & b.1. & b.1. & b.1. & 0.02 \\
\hline $\mathrm{H}_{2} \mathrm{O}^{1}$ & & & & & & 6.41 \\
\hline Total & & 100.00 & 100.00 & 100.00 & 100.00 & 100.00 \\
\hline Cations & & $\mathrm{O}=3$ & $\mathrm{O}=9$ & $\mathrm{O}=6$ & $\mathrm{O}=12$ & $\mathrm{O}=8$ \\
\hline $\mathrm{Ca}$ & apfu & 0.01 & 1.01 & 1.17 & 0.33 & 0.18 \\
\hline $\mathrm{La}$ & & 0.38 & 0.71 & 0.38 & 0.66 & 0.48 \\
\hline $\mathrm{Ce}$ & & 0.47 & 0.98 & 0.49 & 0.91 & 0.64 \\
\hline $\operatorname{Pr}$ & & 0.04 & 0.09 & 0.04 & 0.02 & 0.06 \\
\hline $\mathrm{Nd}$ & & 0.09 & 0.24 & 0.10 & 0.15 & 0.13 \\
\hline $\mathrm{Sm}$ & & 0.00 & 0.01 & 0.01 & 0.01 & 0.00 \\
\hline $\mathrm{Gd}$ & & 0.00 & 0.01 & 0.00 & 0.00 & 0.00 \\
\hline Y & & 0.00 & 0.00 & 0.00 & 0.00 & 0.00 \\
\hline $\mathrm{Sr}$ & & 0.00 & 0.02 & 0.02 & 0.17 & 0.61 \\
\hline $\mathrm{Ba}$ & & 0.00 & 0.00 & 0.00 & 0.87 & 0.02 \\
\hline Th & & 0.00 & 0.01 & 0.00 & 0.00 & 0.02 \\
\hline $\mathrm{Si}$ & & 0.00 & 0.00 & 0.00 & 0.00 & 0.04 \\
\hline $\mathrm{Na}$ & & 0.00 & 0.00 & 0.00 & 0.71 & 0.00 \\
\hline $\mathrm{Al}$ & & 0.00 & 0.00 & 0.00 & 0.02 & 0.00 \\
\hline $\mathrm{U}$ & & 0.00 & 0.00 & 0.00 & 0.00 & 0.00 \\
\hline $\mathrm{F}$ & & 0.74 & 1.67 & 1.00 & 0.96 & 0.19 \\
\hline $\mathrm{Cl}$ & & 0.00 & 0.00 & 0.00 & 0.00 & 0.00 \\
\hline $\mathrm{C}^{2}$ & & 1.00 & 3.00 & 2.00 & 4.00 & 2.00 \\
\hline $\mathrm{H}^{2}$ & & & & & & 3.00 \\
\hline
\end{tabular}


Bastnäsite-(Ce) has a near-ideal composition with 74.2 wt.\% TREO and 8.2 wt.\% F. It is strongly LREE-selective (mainly Ce) with an average Ce/Y ratio of 592 and contains trace amounts of $\mathrm{Gd}_{2} \mathrm{O}_{3}(0.18$ wt.\%) and $\mathrm{Y}(0.06$ wt.\%) as well as $\mathrm{CaO}(0.25$ wt.\%), $\mathrm{ThO}_{2}$ (0.19 wt.\%), $\mathrm{BaO}(0.04$ wt.\%), and $\mathrm{SrO}(0.04$ wt.\%). In some samples there is a small positive chondrite-normalized Eu anomaly (Fig. 26A).

Parisite-(Ce), which occurs as syntactic intergrowths in bastnäsite-(Ce), has TREO and F contents of 60.98 wt. $\%$ and 6.88 wt. $\%$, respectively and a Ce/Y ratio of 242 . The average $\mathrm{CaO}$ content is 10.2 wt.\%, and there are traces of $\mathrm{Sm}_{2} \mathrm{O}_{3}\left(0.25\right.$ wt.\%), $\mathrm{Gd}_{2} \mathrm{O}_{3}(0.30$ wt.\%), and $\mathrm{Y}\left(0.12\right.$ wt.\%) as well as $\mathrm{ThO}_{2}(0.36$ wt.\%), $\mathrm{SrO}(0.3$ wt.\%), and $\mathrm{BaO}(0.04$ wt.\%).

Synchysite-(Ce) was only observed in one sample (WI091006; $90.6 \mathrm{~m}$ depth) and has average REE and $\mathrm{F}$ contents of 48.97 and 5.53 wt.\%, respectively. The average $\mathrm{Ce} / \mathrm{Y}$ ratio is 292 and the $\mathrm{Sm}_{2} \mathrm{O}_{3}\left(0.38\right.$ wt.\%), $\mathrm{Eu}_{2} \mathrm{O}_{3}\left(0.04\right.$ wt.\%), $\mathrm{Gd}_{2} \mathrm{O}_{3}(0.16$ wt.\%), and $\mathrm{Y}$ (0.08 wt.\%) contents are comparable to those of bastnäsite-(Ce) and parisite-(Ce). However, the $\mathrm{Dy}_{2} \mathrm{O}_{3}$ content (below the detection limit) is the lowest of any of the REE minerals. The average $\mathrm{CaO}$ content is $18.98 \mathrm{wt} . \%$, and there are traces of $\mathrm{ThO}_{2}(0.23$ wt.\%), $\mathrm{SrO}(0.52$ wt.\%), and $\mathrm{BaO}(0.05$ wt.\%). Like bastnäsite-(Ce), synchysite-(Ce) displays a slightly positive chondrite-normalized Eu anomaly (Fig. 26C).

Ancylite-(Ce) and cordylite-(Ce) are strongly LREE-enriched. Indeed, with a Ce:Y ratio of 3360, ancylite-(Ce) is the most strongly LREE-enriched mineral in the Wicheeda 
system (Fig. 26D) . It contains an average of 51.62 wt.\% TREO, 14.92 wt.\% SrO and 2.45 wt.\% CaO. As for the REE fluorocarbonate minerals, it contains traces of $\mathrm{Gd}_{2} \mathrm{O}_{3}$ (0.21 wt.\%), and $\mathrm{Y}\left(0.09\right.$ wt.\%) as well as small proportions of $\mathrm{SiO}_{2}(0.51$ wt.\%) and $\mathrm{BaO}$ (0.6 wt.\%), and has the highest $\mathrm{ThO}_{2}(1.67$ wt.\%) content of any of the REE minerals.

Cordylite-(Ce) has the lowest TREO content of any of the REE minerals (42.43 wt.\%; Fig. 26E), and an average $\mathrm{BaO}$ content of 19.76 wt. $\%, \mathrm{CaO}$ content of 2.73 wt. $\%, \mathrm{Na}_{2} \mathrm{O}$ content of 3.25 wt. \%, and $\mathrm{F}$ content of 2.72 wt. \%. The Ce/Y ratio averages 816 and there are traces of $\mathrm{Sm}_{2} \mathrm{O}_{3}\left(0.14\right.$ wt.\%), $\mathrm{Gd}_{2} \mathrm{O}_{3}\left(0.12\right.$ wt.\%), Y (0.03 wt.\%), and $\mathrm{ThO}_{2}(0.09$ wt.\%).

The chondrite-normalized REE-profiles of ancylite-(Ce) and cordylite-(Ce) (Fig. 26D and E) are very similar to those of bastnäsite-(Ce) and synchysite-(Ce), although the HREE contents of ancylite-(Ce) and cordylite-(Ce) are higher. In some samples both ancylite(Ce) and cordylite-(Ce) display small positive Eu anomalies.

\section{Monazite-(Ce)}

As discussed earlier, monazite-(Ce) occurs mainly as fine-grained euhedral lath-like inclusions in albite+apatite xenoliths in dolomite carbonatite and as inclusions in the REE-fluorocarbonates, and to a much lesser extent near apatite in the potassic fenite. Like the other REE minerals, monazite-(Ce) is strongly enriched in the LREE (Table 7; $\mathrm{Ce} / \mathrm{Y}$ of 565) and contains traces of $\mathrm{Sm}_{2} \mathrm{O}_{3}\left(0.55\right.$ wt.\%), $\mathrm{Gd}_{2} \mathrm{O}_{3}(0.42$ wt.\%), and $\mathrm{Y}(0.11$ wt.\%). There are also minor concentrations of $\mathrm{SiO}_{2}\left(0.17\right.$ wt.\%), $\mathrm{ThO}_{2}(0.09$ wt.\%), $\mathrm{CaO}$ 
(0.22 wt.\%), and $\mathrm{Sr}(0.23$ wt.\%). The slopes of the chondrite-normalized REE profiles are much lower than those of bastnäsite-(Ce), ancylite-(Ce), and cordylite-(Ce), and are comparable to those of parisite-(Ce) and synchysite-(Ce) (Fig. 26A to F), which reflects the higher HREE content of monazite-(Ce), parisite-(Ce), and synchysite-(Ce) (Table 6 and Table 7). 

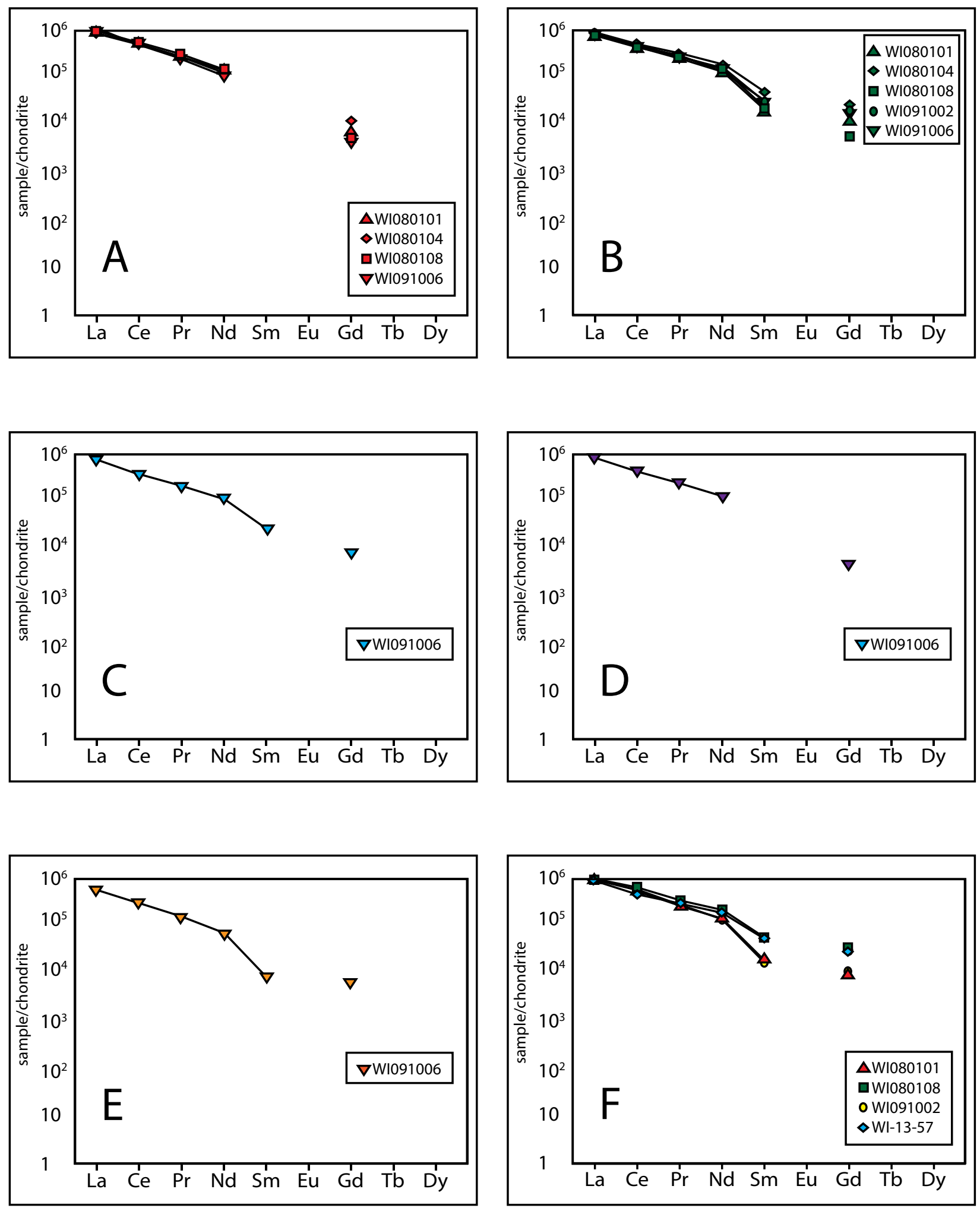

Fig. 26: A-F: Chondrite-normalized REE-profiles for the major REE-bearing minerals in the Wicheeda carbonatite. A. Bastnäsite-(Ce). B. Parisite-(Ce). C. Synchysite-(Ce). D. Ancylite-(Ce) E. Cordylite-(Ce). F. Monazite-(Ce). The chondrite values were taken from McDonough and Sun (1995). 
Table 7: Average composition of monazite-(Ce) in potassic fenite (KFEN) and dolomite carbonatite (Cd).

\begin{tabular}{|c|c|c|c|c|c|}
\hline \multirow{3}{*}{$\begin{array}{c}\text { Mineral } \\
\text { Rock Type } \\
\text { Sample }\end{array}$} & & \multicolumn{4}{|c|}{ Monazite-(Ce) } \\
\hline & & $K F E N$ & $C d$ & $C d$ & $C d$ \\
\hline & & $\begin{array}{c}\text { WI-13-57 } \\
n=19\end{array}$ & $\begin{array}{c}\text { WI080101 } \\
n=4\end{array}$ & $\begin{array}{c}\text { WI080108 } \\
n=20\end{array}$ & $\begin{array}{c}\text { WI091002 } \\
n=14\end{array}$ \\
\hline$\overline{\mathrm{La}_{2} \mathrm{O}_{3}}$ & wt. $\%$ & 22.23 & 24.81 & 22.92 & 24.12 \\
\hline $\mathrm{Ce}_{2} \mathrm{O}_{3}$ & & 32.60 & 33.74 & 31.73 & 34.79 \\
\hline $\mathrm{Pr}_{2} \mathrm{O}_{3}$ & & 3.00 & 2.86 & 2.96 & 2.81 \\
\hline $\mathrm{Nd}_{2} \mathrm{O}_{3}$ & & 8.63 & 6.91 & 8.89 & 6.67 \\
\hline $\mathrm{Sm}_{2} \mathrm{O}_{3}$ & & 0.78 & 0.28 & 0.89 & 0.26 \\
\hline $\mathrm{Gd}_{2} \mathrm{O}_{3}$ & & 0.62 & 0.20 & 0.64 & 0.22 \\
\hline $\mathrm{Y}_{2} \mathrm{O}_{3}$ & & b.l. & 0.20 & 0.03 & 0.16 \\
\hline $\mathrm{P}_{2} \mathrm{O}_{5}$ & & 29.54 & 30.26 & 28.74 & 29.09 \\
\hline $\mathrm{CaO}$ & & 0.28 & 0.21 & 0.28 & 0.11 \\
\hline $\mathrm{SrO}$ & & 0.31 & 0.09 & 0.45 & 0.07 \\
\hline $\mathrm{ThO}_{2}$ & & 0.87 & 1.08 & 0.50 & 0.58 \\
\hline $\mathrm{SiO}_{2}$ & & 0.19 & 0.24 & 0.09 & 0.16 \\
\hline $\mathrm{F}$ & & 0.24 & 0.28 & 0.21 & 0.20 \\
\hline Total & & 99.84 & 98.82 & 100.33 & 100.54 \\
\hline Cations & & $\mathrm{O}=4$ & & & \\
\hline $\mathrm{La}$ & apfu & 0.32 & 0.35 & 0.34 & 0.35 \\
\hline $\mathrm{Ce}$ & & 0.47 & 0.48 & 0.47 & 0.51 \\
\hline $\operatorname{Pr}$ & & 0.04 & 0.04 & 0.04 & 0.04 \\
\hline $\mathrm{Nd}$ & & 0.12 & 0.10 & 0.13 & 0.10 \\
\hline $\mathrm{Sm}$ & & 0.01 & 0.00 & 0.01 & 0.00 \\
\hline Gd & & 0.01 & 0.00 & 0.01 & 0.00 \\
\hline $\mathrm{Y}$ & & 0.00 & 0.00 & 0.01 & 0.00 \\
\hline $\mathrm{P}$ & & 0.99 & 0.99 & 0.98 & 0.98 \\
\hline $\mathrm{Ca}$ & & 0.01 & 0.01 & 0.01 & 0.00 \\
\hline $\mathrm{Sr}$ & & 0.00 & 0.00 & 0.01 & 0.00 \\
\hline $\mathrm{Th}$ & & 0.01 & 0.00 & 0.00 & 0.01 \\
\hline $\mathrm{Si}$ & & 0.01 & 0.01 & 0.00 & 0.01 \\
\hline $\mathrm{F}$ & & 0.03 & 0.03 & 0.03 & 0.02 \\
\hline
\end{tabular}




\section{Apatite}

Electron microprobe analyses of grains from the potassic (WI-13-37; WI-13-55) and sodic (WI-13-01) fenite revealed the mineral referred to earlier as apatite is in fact fluorapatite. Fluorapatite from the potassic fenite (Apatite 1) contains 0.14 wt. $\% \mathrm{Na}_{2} \mathrm{O}$, 0.53 wt.\% SrO, 0.86 wt.\% LREE and minor concentrations of HREE (e.g., $\mathrm{Y}_{2} \mathrm{O}_{3}=0.04$ wt.\%); $\mathrm{ThO}_{2}$ is near the detection limit (Table 8). By contrast, fluorapatite from the sodic fenite (Apatite 2) has higher $\mathrm{Na}_{2} \mathrm{O}$ (0.25 wt.\%), SrO (1.03 wt.\%), and HREE (e.g., $\mathrm{Y}_{2} \mathrm{O}_{3}$ $=0.42$ wt. $\%$ ) contents but lower LREE (0.7 wt.\%). The $\mathrm{ThO}_{2}$ contents are near the detection limit. The REE-profiles of Apatite 1 (e.g., Fig. 27A) are relatively flat with very modest HREE-enrichment whereas those of Apatite 2 (e.g., Fig. 28B) are flat or slightly LREE-enriched. In addition, Apatite 1 is compositionally zoned with a REEpoor core and a REE-enriched rim, whereas Apatite 2 is unzoned. 
Table 8: Average composition of fluorapatite in sodic fenite (AFEN) and potassic fenite (KFEN).

\begin{tabular}{|c|c|c|c|c|}
\hline \multirow{3}{*}{$\begin{array}{c}\text { Mineral } \\
\text { Rock Type } \\
\text { Sample }\end{array}$} & & \multicolumn{3}{|c|}{ Apatite } \\
\hline & & $A F E N$ & KFEN & KFEN \\
\hline & & WI-13-01 & WI-13-37 & WI-13-55 \\
\hline $\mathrm{CaO}$ & wet $0 \%$ & 5384 & 5437 & 5420 \\
\hline & & דo.0 & וס וניד & \\
\hline $\mathrm{P}_{2} \mathrm{O}_{5}$ & & 40.89 & 40.93 & 41.72 \\
\hline $\mathrm{Na}_{2} \mathrm{O}$ & & 0.25 & 0.12 & 0.16 \\
\hline $\mathrm{SrO}$ & & 1.03 & 0.43 & 0.62 \\
\hline $\mathrm{SiO}_{2}$ & & b.l. & 0.41 & 0.12 \\
\hline $\mathrm{ThO}_{2}$ & & b.1. & 0.05 & b.l. \\
\hline $\mathrm{La}_{2} \mathrm{O}_{3}$ & & b.1. & 0.14 & 0.20 \\
\hline $\mathrm{Ce}_{2} \mathrm{O}_{3}$ & & 0.20 & 0.38 & 0.42 \\
\hline $\mathrm{Nd}_{2} \mathrm{O}_{3}$ & & 0.13 & 0.18 & 0.14 \\
\hline $\mathrm{Y}_{2} \mathrm{O}_{3}$ & & 0.42 & b.1. & b.l. \\
\hline $\mathrm{F}$ & & 3.86 & 3.50 & 3.77 \\
\hline $\mathrm{Cl}$ & & b.1. & 0.10 & b.1. \\
\hline Total & & 99.42 & 99.28 & 100.06 \\
\hline \multicolumn{5}{|l|}{ Cations } \\
\hline $\mathrm{Ca}$ & apfu & 4.84 & 4.95 & 4.93 \\
\hline $\mathrm{P}$ & & 2.89 & 2.94 & 2.98 \\
\hline $\mathrm{Na}$ & & 0.08 & 0.02 & 0.03 \\
\hline $\mathrm{Sr}$ & & 0.05 & 0.02 & 0.03 \\
\hline $\mathrm{Si}$ & & 0.00 & 0.04 & 0.01 \\
\hline Th & & 0.00 & 0.00 & 0.00 \\
\hline $\mathrm{La}$ & & 0.00 & 0.00 & 0.01 \\
\hline $\mathrm{Ce}$ & & 0.01 & 0.01 & 0.01 \\
\hline $\mathrm{Nd}$ & & 0.00 & 0.01 & 0.00 \\
\hline $\mathrm{Y}$ & & 0.02 & 0.00 & 0.00 \\
\hline $\mathrm{F}$ & & 0.96 & 0.87 & 0.94 \\
\hline $\mathrm{Cl}$ & & 0.00 & 0.01 & 0.00 \\
\hline
\end{tabular}

Notes: b.l. Below detection limits for oxides (wt.\%), as noted in Appendix D 

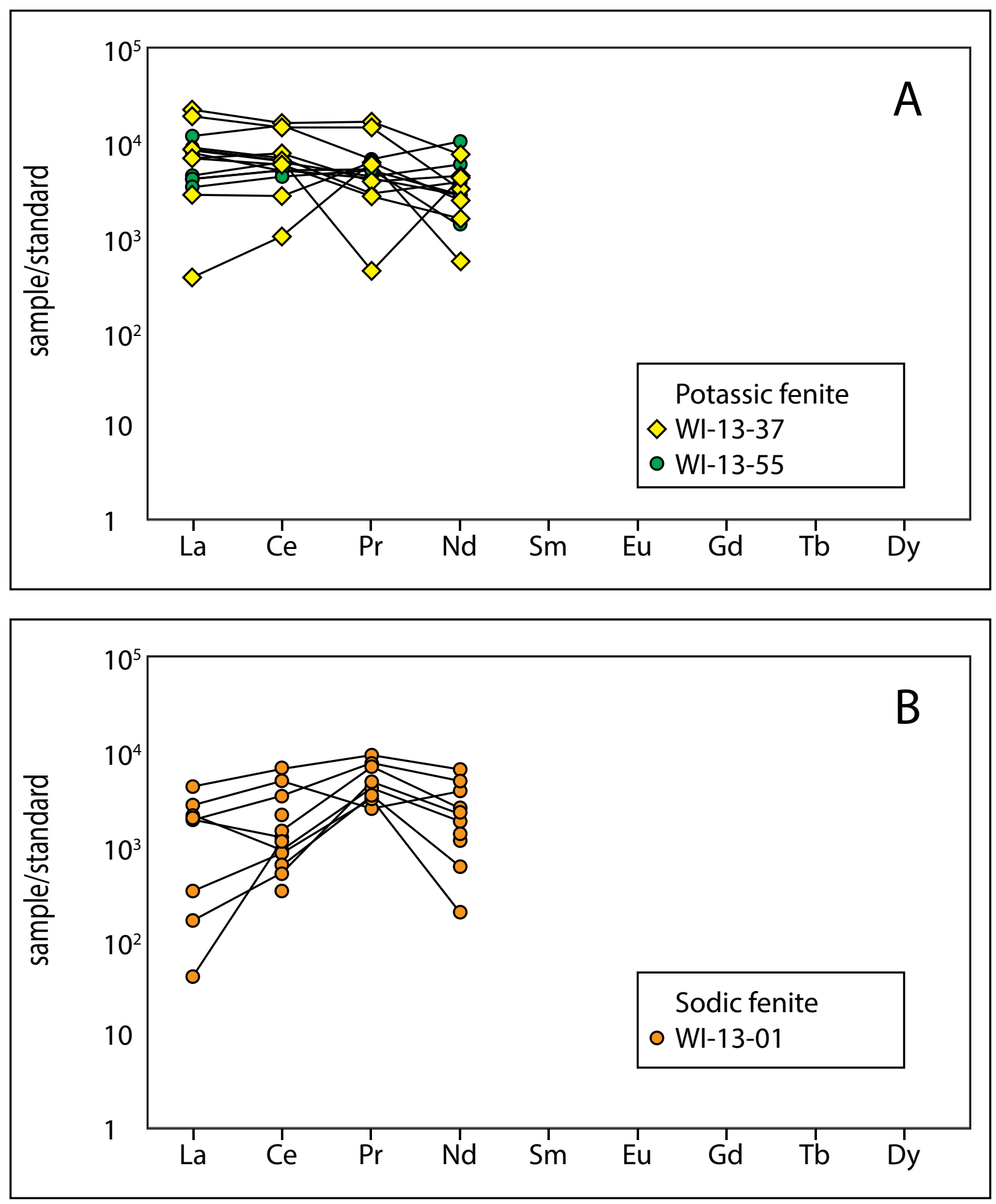

Fig. 27: Chondrite-normalized REE-profiles for fluorapatite samples from potassic fenite, A, and sodic fenite, B. The chondrite values were obtained from McDonough and Sun (1995). 


\section{Stable Isotope Geochemistry}

A total of 20 samples of calcite, Dolomite 1, Dolomite 2, and Dolomite 3 were analyzed for their oxygen and carbon isotopes and standardized to $\delta{ }^{13} \mathrm{C}$ V-PDB and $\delta{ }^{18} \mathrm{O} \mathrm{V}$ SMOW, the results of which are summarized in Table 9. The $\delta{ }^{13} \mathrm{C}$ values of calcite in calcite carbonatite range from -6.31 to $-6.27 \%$ and the $\delta{ }^{18} \mathrm{O}$ values from 6.91 to 6.97 \%o. Samples from the dolomite carbonatite have much higher values. The $\delta{ }^{13} \mathrm{C}$ and $\delta$ ${ }^{18} \mathrm{O}$ values of Dolomite 1 range from -5.67 to $-5.48 \%$ and from 9.35 to $10.02 \%$, respectively. Dolomite 2 has similar $\delta{ }^{13} \mathrm{C}$ and $\delta{ }^{18} \mathrm{O}$ values of -5.59 to $-5.38 \%$ and 9.91 to $10.22 \%$, respectively. The $\delta{ }^{13} \mathrm{C}$ and $\delta{ }^{18} \mathrm{O}$ values of Dolomite 3 , however, are significantly higher, ranging from -5.41 to $-4.66 \%$ and from 11.05 to $12.03 \%$, respectively. 
Table 9: Carbon and oxygen isotopic compositions of calcite carbonatite (Ce), Dol 1, Dol 2, and Dol 3.

\begin{tabular}{|c|c|c|c|c|}
\hline $\begin{array}{l}\text { Sample } \\
\text { Name }\end{array}$ & std. & $\begin{array}{c}\delta^{13} \mathrm{C} \\
\text { V-PDB }\end{array}$ & $\begin{array}{c}\delta^{18} \mathrm{O} \\
\mathrm{V}-\mathrm{SMOW}\end{array}$ & 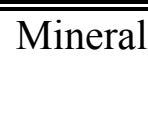 \\
\hline 08010101 & & -5.38 & 9.92 & Dol 2 \\
\hline 08010102 & & -5.28 & 11.70 & Dol 3 \\
\hline 08010103 & & -5.15 & 11.85 & Dol 3 \\
\hline 08010113 & & -5.19 & 11.05 & Dol 3 \\
\hline 08010114 & & -4.66 & 12.03 & Dol 3 \\
\hline 08010804 & & -5.57 & 10.15 & Dol 2 \\
\hline 09080601 & & -6.31 & 6.97 & $\mathrm{Cc}$ \\
\hline 09080602 & & -6.27 & 6.91 & $\mathrm{Cc}$ \\
\hline 09082201 & & -5.67 & 9.57 & Dol 1 \\
\hline 09082202 & & -5.49 & 10.22 & Dol 2 \\
\hline 09090801 & & -5.61 & 10.02 & Dol 1 \\
\hline 09090901 & & -5.48 & 9.36 & Dol 1 \\
\hline 09090902 & & -5.59 & 9.94 & Dol 1 \\
\hline 09100601 & & -5.04 & 11.14 & Dol 3 \\
\hline 09100602 & & -5.15 & 11.12 & Dol 3 \\
\hline 09100603 & & -4.96 & 11.32 & Dol 3 \\
\hline 09100604 & & -4.96 & 11.34 & Dol 3 \\
\hline 09100901 & & -5.59 & 9.91 & Dol 2 \\
\hline 09101101 & & -5.48 & 10.17 & Dol 2 \\
\hline 09101102 & & -5.41 & 11.82 & Dol 3 \\
\hline
\end{tabular}




\section{Discussion}

\section{Magmatic Evolution}

As is the case for carbonatites elsewhere (Woolley and Kempe, 1989), the Wicheeda Carbonatite is characterized by high concentrations of HFSE and the REE, and elevated concentrations of $\mathrm{F}$ and the large ion lithophile element, $\mathrm{Ba}$. These elements are incompatible, and concentrate in carbonatites because they are either the products of very small degrees of melting of a carbonated mantle or because they represent the end stages of evolution of an alkaline silicate mantle melt (Freestone and Hamilton, 1980; Kjarsgaard and Hamilton, 1988; Hamilton et al., 1989; Lee and Wyllie, 1998) or a liquid exsolved from that melt (von Eckermann, 1948; Eggler, 1974; Eggler, 1978; Eggler, 1989; Sweeney, 1994; Gittins and Harmer, 1998). The carbon and oxygen isotopic data discussed below indicate that the calcite carbonatite had a mantle origin, whereas the dolomite carbonatite likely originated from a more evolved source. The dolomite carbonatite also differs from the calcite carbonatite in being much more enriched in the $\mathrm{REE}$ and relatively depleted in $\mathrm{Nb}$. If emplacement of the calcite carbonatite preceded emplacement of the dolomite carbonatite, which is a common characteristic of other carbonatites including Ngualla and Panda Hills, Tanzania (Van Straaten, 1989; Le Bas, 1977), Khibina, Russia (Le Bas, 1981; Zaitsev 1998; Zaitsev et al., 2014), and St. Honoré, Quebec (Fortin-Bélanger, 1977; Fournier, 1993) and a reasonable assumption given its location at the margins of the intrusion, then it follows that $\mathrm{Nb}$ enrichment occurred early and was followed by later REE enrichment. This interpretation is supported by experimental evidence demonstrating that, although $\mathrm{Nb}$ is typically more incompatible than the REE in igneous systems, pyrochlore, the principal niobium-bearing 
mineral in carbonatites has a very low solubility in carbonatite magmas (Jago and Gittins, 1993; Mitchell and Kjarsgaard, 2002; 2004) compared to the REE (Jones and Wyllie, $1983 ; 1986)$. Indeed, as discussed earlier, the Wicheeda pyrochlore occurs as euhedra in calcite (calcite carbonatite), suggesting an early magmatic origin, whereas the REE mineralization (largely in the dolomite carbonatite) was clearly later. The proposed evolution from calcite carbonatite to dolomite carbonatite is predicted by experimental data for the system $\mathrm{CaO}-\mathrm{MgO}-\mathrm{FeO}$ showing that calcite is the first mineral to appear on the liquidus (Irving and Wyllie, 1975; Byrnes and Wyllie, 1981; Shatskiy et al., 2014). The extent to which the dolomite carbonatite evolved is less clear. Inspection of Figure 11 shows that the bulk rock compositions of most samples of dolomite carbonatite cluster near the $\mathrm{MgO}$-rich and $\mathrm{CaO}$-poor limit of the field of ferruginous calcio-carbonatite but that there is a weak trend from magnesio-carbonatite to ferrocarbonatite. Consistent with the experimental studies referred to above and the magnesium-rich nature of Dolomite 1 relative to the later dolomite types (Fig. 21), we propose that this trend is magmatic and represents the fractionation of a magnesio-carbonatite magma to a ferrocarbonatite composition. Significantly, REE mineralization occurred relatively early in this evolution as shown by the fact that the magnesio-carbonatite is more enriched in REE than the ferro-carbonatite. 


\section{Subsolidus Evolution}

\section{Carbon and oxygen isotopes}

The carbon and oxygen isotopic composition of the calcite in the calcite carbonatite is consistent with a mantle origin as discussed in the previous section (Fig. 28). However, the carbon and oxygen isotopic composition of Dolomite 1 plots outside the mantle field, although largely within the primary igneous carbonatite field, and that of Dolomite 2 straddles the boundary between the field of primary igneous carbonatite and the field of carbonates of secondary origin. Indeed, the abundance of fluid inclusions in Dolomite 2 suggests a contribution to its isotopic composition from hydrothermal or carbohydrothermal fluids. In contrast to Dolomite 1 and Dolomite 2, the composition of Dolomite 3 plots entirely in the field of secondary carbonate, well removed from the field of primary igneous carbonatite, consistent with its occurrence as a vug-filling phase. A potentially significant feature of the isotopic compositions of the three dolomite types and calcite of the calcite carbonatite is that they are linearly distributed with a trend roughly parallel to that reflecting interaction between carbonatite and a hydrothermal or carbohydrothermal fluid (Fig. 28). 


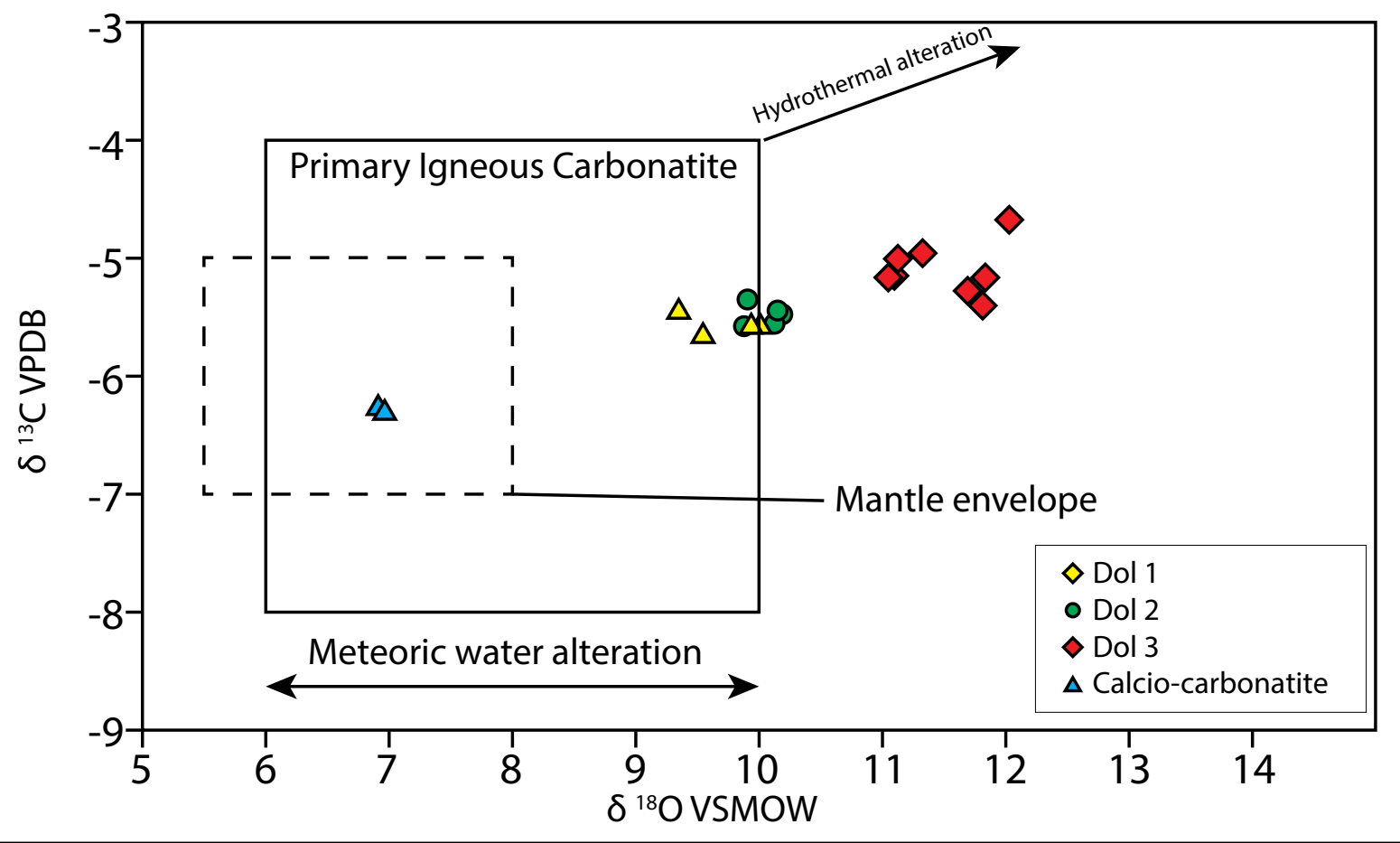

Fig. 28: A plot of $\delta^{18} \mathrm{O}$ VSMOW versus $\delta^{13} \mathrm{C}$ VPDB showing the distribution of oxygen and carbon isotopic ratios in the dolomite carbonatite (Dolomite 1, Dolomite 2, Dolomite 3) and calcite carbonatite. The data were normalized to V-SMOW and V-PDB, respectively. Also shown are the fields of mantle-derived carbonatite, primary magmatic carbonatite, and secondary carbonate resulting from interaction of the carbonatite with hydrothermal fluids and meteoric water after Taylor et al. (1969), Deines (1989), and Keller and Hoefs (1995). 
Assuming that the trend referred to above might have resulted from equilibration of the carbonatites with a fluid exsolved from the magma, we have interpreted the isotopic data using the Rayleigh fractionation model developed by Pineau et al. (1973) and Deines (1989) and revised by Ray and Ramesh (2000). The carbon isotopic evolution of carbonatite is given by:

$$
\delta^{13} \mathrm{C}=\alpha^{\mathrm{c}}\left(1000+\delta{ }^{13} \mathrm{C}_{\mathrm{s}}^{\mathrm{i}}\right)\left[\mathrm{f}_{\mathrm{c}}\right]^{\left(\alpha^{\mathrm{c}}-1\right)}-1000
$$

where $\alpha^{\mathrm{c}}$ is the fractionation factor of carbon between carbonate (dolomite) and $\mathrm{CO}_{2}, \mathrm{f}_{\mathrm{c}}$ is the fraction of remaining carbon in the source, and $\delta{ }^{13} \mathrm{C}_{\mathrm{s}}{ }^{\mathrm{i}}$ is the initial carbon isotopic composition of the source. The oxygen isotopic composition is given by:

$$
\delta^{18} O_{d o l}=10^{3}\left(\frac{\alpha_{d-1}^{o}}{a-\frac{b}{f_{O}}}-1\right)+\left(\frac{\alpha_{d-1}^{o}}{a-\frac{b}{f_{O}}}\right)\left(\delta^{18} O_{S}\right)
$$

where $\alpha_{d-1}^{0}$ is the isotopic fractionation factor for oxygen between dolomite and the largest source component (i.e., $\mathrm{CO}_{2}$ or $\mathrm{H}_{2} \mathrm{O}$ ), $f_{o}$ is the fraction of oxygen remaining in the reservoir, $\mathrm{a}$ and $\mathrm{b}$ are the number of atoms contributed by the sources and $\delta^{18} \mathrm{O}_{\mathrm{S}}$ is the oxygen isotopic composition of the source. If we assume that $\mathrm{H}_{2} \mathrm{O}$ is the largest source component for oxygen (see below), the value of $f_{o}$ for which $\mathrm{CO}_{2}$ is exhausted is given by: 


$$
\begin{gathered}
f_{\mathrm{CO}_{2}}=\frac{1-\mathrm{r}_{\mathrm{CO}_{2}-\mathrm{H}_{2} \mathrm{O}}}{1+2 \mathrm{r}_{\mathrm{CO}_{2}-\mathrm{H}_{2} \mathrm{O}}} \\
a=1+\frac{2}{3}\left(\alpha_{\mathrm{CO}_{2}-\mathrm{H}_{2} \mathrm{O}}-1\right) \\
b=\frac{2}{3}\left(\alpha_{\mathrm{CO}_{2}-\mathrm{H}_{2} \mathrm{O}}-1\right)\left(\frac{1-\mathrm{r}_{\mathrm{CO}_{2}-\mathrm{H}_{2} \mathrm{O}}}{1+2 \mathrm{r}_{\mathrm{CO}_{2}-\mathrm{H}_{2} \mathrm{O}}}\right)
\end{gathered}
$$

where $\mathrm{r}_{\mathrm{CO}_{2}-\mathrm{H}_{2} \mathrm{O}}$ is the ratio of $\mathrm{CO}_{2}$ to $\mathrm{H}_{2} \mathrm{O}$ in the fluid and $\alpha_{\mathrm{CO}_{2}-\mathrm{H}_{2} \mathrm{O}}$ is the isotopic fractionation factor for oxygen between $\mathrm{CO}_{2}$ and $\mathrm{H}_{2} \mathrm{O}$. The value of $\delta{ }^{18} \mathrm{O}_{\mathrm{s}}$ is determined by the relationship:

$$
\left(\delta^{18} O_{s}-\delta^{18} O_{s}^{i}\right)=10^{3}\left\{\left(\frac{\alpha_{d-1}^{O}}{a}\right) * \ln \left(\frac{a f_{O}-b}{a-b}\right)-\ln \left(f_{o}\right)\right\}
$$

In order to correlate the carbon isotopic composition to that of oxygen in the carbonatite, the fraction of carbon remaining in the source $\left(f_{c}\right)$ is related to that of oxygen remaining in the source $\left(f_{o}\right)$ by the equation:

$$
f_{c}=\left(\frac{1-\mathrm{r}_{\mathrm{H}_{2} \mathrm{O}-\mathrm{CO}_{2}}}{3}\right)+f_{O}\left(\frac{2+\mathrm{r}_{\mathrm{H}_{2} \mathrm{O}-\mathrm{CO}_{2}}}{3}\right)
$$

Application of the above equations in modeling the trend shown in Figure 28 requires an estimate for the initial isotopic composition of the source fluid and estimates for either the temperature or the molar ratio of $\mathrm{CO}_{2}$ to $\mathrm{H}_{2} \mathrm{O}$ (r) in this fluid. Although the REE mineralization is hosted by the dolomite carbonatite, we have assumed that the exsolved 
fluid had the same carbon and oxygen isotopic composition as the calcite carbonatite, i.e., a $\delta{ }^{13} \mathrm{C}$ value of -6.27 and a $\delta{ }^{18} \mathrm{O}$ value of $6.91 \%$. The reasons for this are: 1) judging by its carbon and oxygen isotopic composition, even the least evolved dolomite carbonatite may have been altered;2) the contact between the calcite carbonatite and the dolomite carbonatite is gradational; and 3) the $\mathrm{C}$ and $\mathrm{O}$ isotopic ratios plot along a line extending from calcite in the calcite carbonatite to Dolomite 3 (Fig. 28). The fluid inclusion studies referred to earlier indicate that fluids exsolved from carbonatites contain appreciable proportions of both $\mathrm{CO}_{2}$ and $\mathrm{H}_{2} \mathrm{O}$. On the basis of visual estimates of the volumetric proportions of $\mathrm{CO}_{2}$ and $\mathrm{H}_{2} \mathrm{O}$ in large numbers of fluid inclusions, Bühn and Rankin (1999) concluded that the fluids exsolved from the REE-bearing Kalkfeld carbonatite, Namibia, contained equal weight proportions of $\mathrm{CO}_{2}$ and $\mathrm{H}_{2} \mathrm{O}$, corresponding to a molar ratio of $0.41: 1$. Bühn et al. (2002) reached a similar conclusion for the Okorusu carbonatite, Namibia. We have therefore modeled the data for a value of $r$ of 0.41 (molar $\mathrm{CO}_{2}: \mathrm{H}_{2} \mathrm{O}$ ). The fractionation factors were determined using the thermodynamic data of Richet et al. (1977), Chacko et al. (1991), Rosenbaum (1994), Zheng (1999), and Horita (2014). By fixing the value of $r$, we were able to vary temperature until the model curve fitted the measured distribution of $\delta{ }^{13} \mathrm{C}$ and $\delta{ }^{18} \mathrm{O}$ values in dolomite. This was achieved when the temperature was set to a value of $310^{\circ} \mathrm{C}$ (Fig. 29). Significantly, the highest temperature that fitted any value of $r$ was $400{ }^{\circ} \mathrm{C}$, and was obtained when the data were modeled with a value of $\mathrm{r}$ of 0.47 . We therefore conclude, on the basis of the $\mathrm{C}$ and $\mathrm{O}$ isotopic data, that the carbonatite evolved by reaction with its exsolved fluid in a closed system, culminating in the precipitation of Dolomite 3 and the REE minerals at a temperature between 300 and $400{ }^{\circ} \mathrm{C}$. 


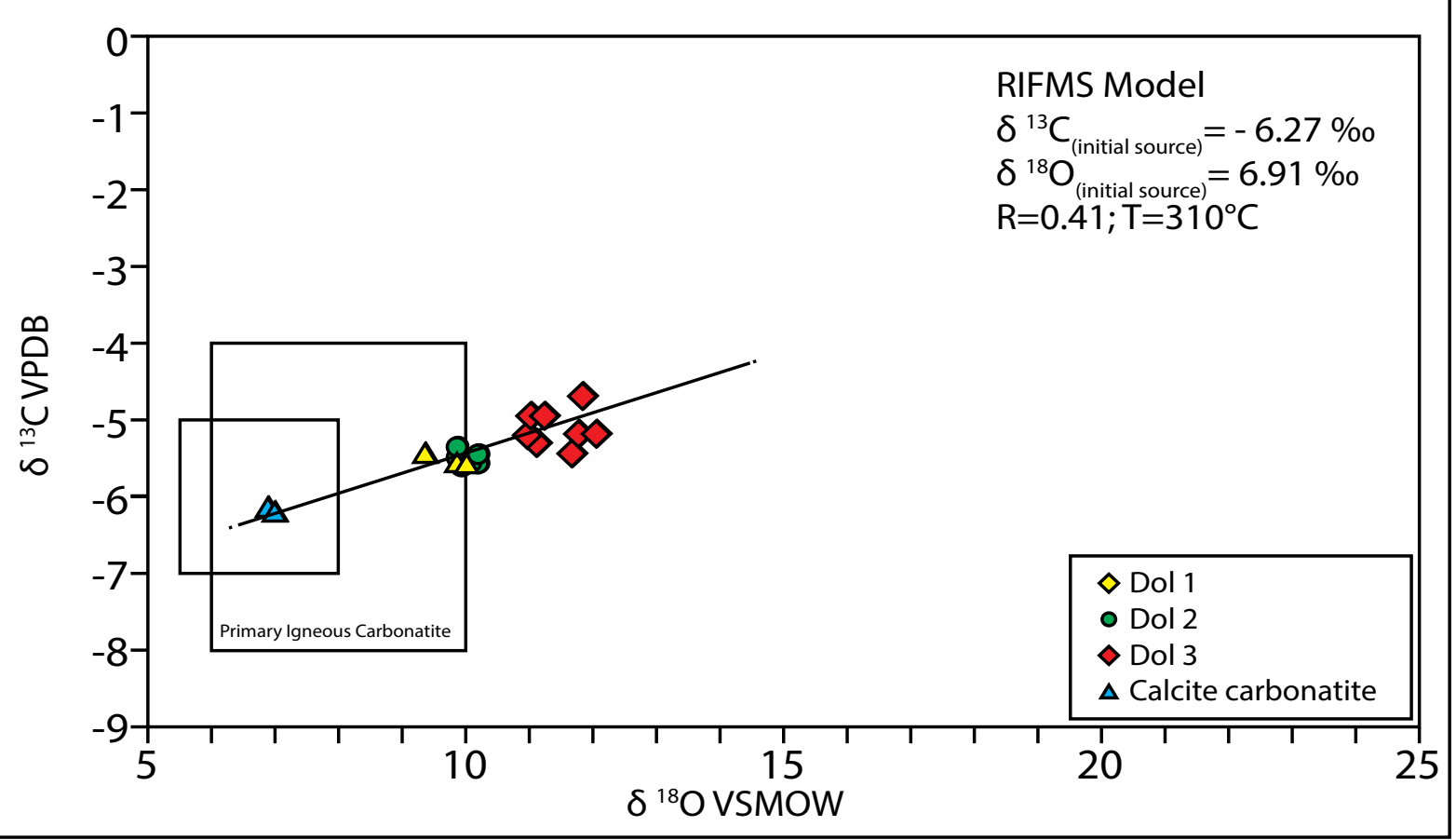

Fig. 29: A plot of $\delta 180$ VSMOW versus $\delta 13 \mathrm{C}$ VPDB showing the distribution of oxygen and carbon isotopic ratios in the dolomite carbonatite (Dolomite 1, Dolomite 2, Dolomite 3) and calcite carbonatite. The black dashed line represents the trend in isotopic composition of the carbonate minerals resulting from closed system Raleigh-type fractionation of the carbonatite with its exsolved fluid. The fluid was assumed to have an initial composition of $\delta 18 \mathrm{O}=6.91 \%$ and $\delta 13 \mathrm{C}$ $=-6.27 \%$ and to have a molar $\mathrm{CO} 2: \mathrm{H} 2 \mathrm{O}$ ratio of 0.41 . The calculated line replicates the measured isotopic values if the temperature is $310^{\circ} \mathrm{C}$. See the main text for details of the calculation. 


\section{Dolomite alteration}

On the basis of its textural relationships and $\mathrm{C}$ and $\mathrm{O}$ isotopic composition, we interpret Dolomite 1 to be of magmatic origin, although it may have been partially altered by hydrothermal fluids. Dolomite 2 inherited a largely magmatic signature but textural relationships indicate that it replaced Dolomite 1. This, and the abundance of fluid inclusions in Dolomite 2 are interpreted to indicate that it is a secondary mineral (hydrothermal), an interpretation supported by the observation that its $\mathrm{C}$ and $\mathrm{O}$ isotopic ratios are slightly higher than those of Dolomite 1. Dolomite 3, which, as already noted, occupies vugs and fractures, clearly precipitated from hydrothermal or carbohydrothermal fluids; this interpretation is supported by the $\mathrm{C}$ and $\mathrm{O}$ isotopic data. Significantly, Dolomite 3 is accompanied by REE mineralization. The replacement of Dolomite 1 by Dolomite 2 was accompanied by an increase in the $(\mathrm{FeO}+\mathrm{MnO}): \mathrm{MgO}$ ratio. We interpret this to indicate that formation of Dolomite 2 resulted from the interaction of Dolomite 1 with a fluid that partially dissolved Dolomite 1, and substituted $\mathrm{Fe}$ and $\mathrm{Mn}$ for $\mathrm{Mg}$. This fluid eventually saturated with dolomite and precipitated Dolomite 3, which has the highest $(\mathrm{FeO}+\mathrm{MnO}) / \mathrm{MgO}$ ratio of the three dolomite types.

\section{Fenitization}

Whereas primary sedimentary features (e.g., laminations), euhedral fluorapatite grains, and a low frequency of veining are observed in the sodic fenite, the potassic fenite is characterized by the complete destruction of sedimentary features, the occurrence of anhedral fluorapatite grains, and a much greater proportion of veins including some containing monazite-(Ce). This is consistent with the distal and proximal locations of the sodic and potassic fenite, respectively. In principle, the two fenites could be products of a 
single fluid emanating from the carbonatite. However, for a fixed fluid composition, albite formation is favored by increasing temperature and potassium feldspar formation by decreasing temperature (Lagache and Weisbrod, 1977). Assuming, as seems reasonable, that temperature decreased with increasing distance from the Wicheeda Carbonatite, it therefore follows that different fluids produced the sodic and potassic fenites. The distribution of the REE in fluorapatite, a mineral occurring in both fenites, provides important clues about the source of the fluids. The chondrite-normalized REE profiles of fluorapatite from the potassic fenite (Apatite 1) generally have negative slopes, indicating preferential enrichment in the LREE, whereas the slopes of the profiles for fluorapatite from the sodic fenite (Apatite 2) are horizontal to positive (Fig. 27). Moreover the LREE content (specifically La and Ce) of the potassic fenite samples, on average, is about an order of magnitude higher than that of the sodic fenite. Given the LREE enrichment of the carbonatite, this suggests strongly that the fluid which produced the potassic fenite originated in the carbonatite, and that the fluid which produced the sodic fenite had another source.

As potassic fenite (mainly potassium feldspar) has been shown elsewhere to be the product of saline aqueous-carbonic fluids released by a carbonatite magma (e.g., Williams-Jones and Palmer, 2002), we propose that such fluids were also responsible for the formation of potassic fenite around the Wicheeda Carbonatite. This interpretation is consistent with the observation that albite and aegirine in the Kechika metasedimentary rocks were replaced by potassium feldspar and biotite. Although we cannot confidently identify the fluid responsible for the formation of the sodic fenite, the most plausible 
explanation is that it was formational water that was heated by the Wicheeda Carbonatite.

If this were the case, and the fluids were initially in equilibrium with potassium feldspar and plagioclase (these minerals commonly occur together in clastic metasedimentary rocks), then their heating would have caused them to reach equilibrium with albite alone (Fig. 30). 


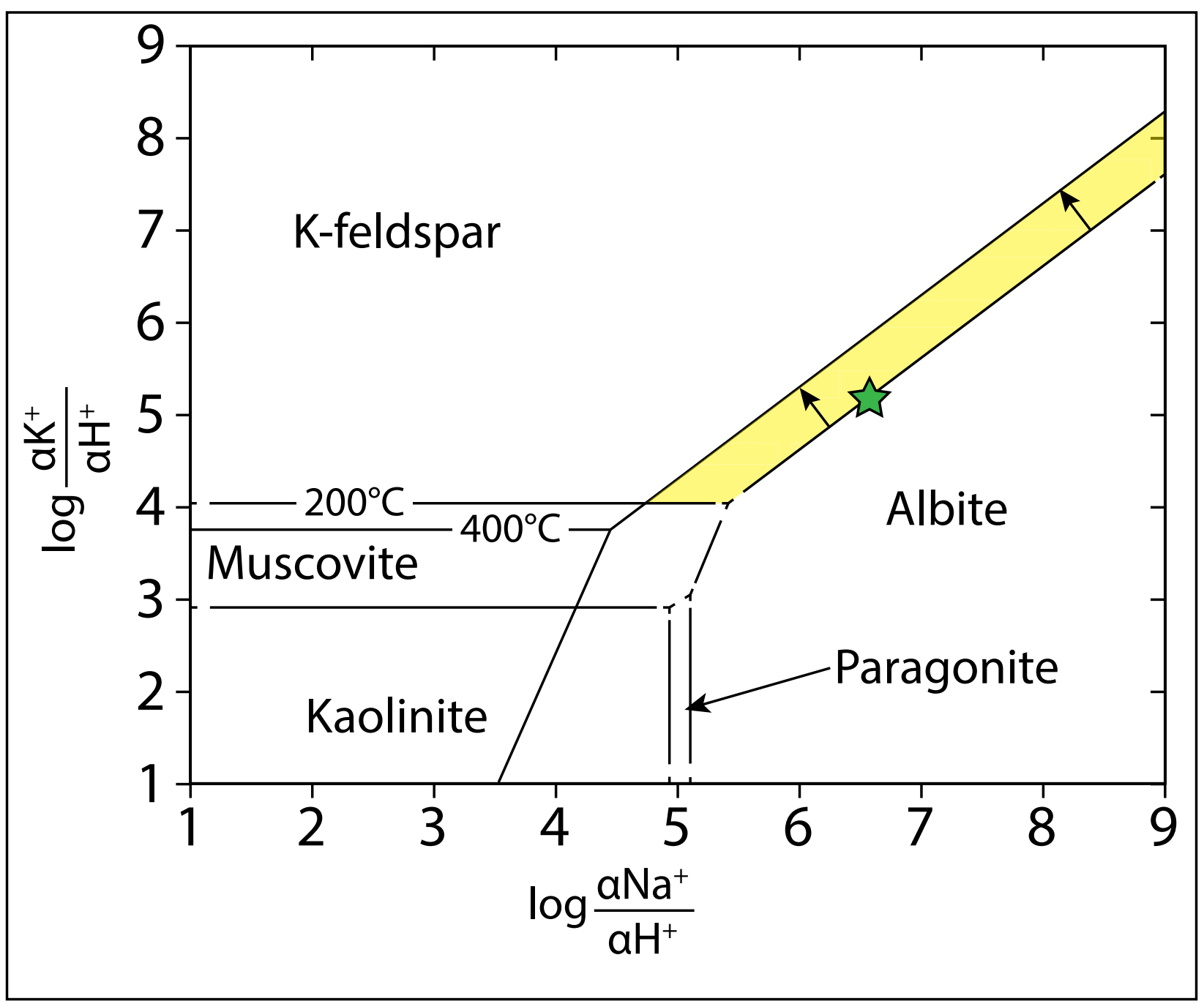

Fig. 30: Stability relationships of minerals in the system K-Na-Al-Si-OH as a function of log $\mathrm{aK}^{+} / \mathrm{aH}^{+}$and $\log \mathrm{aNa}^{+} / \mathrm{aH}^{+}$. The stability field for albite expands with increasing temperature at the expense of the stability fields for K-feldspar and muscovite. For example, formational waters in the Kechika argillaceous limestone (represented by the green star) are in equilibrium with both $\mathrm{K}$-feldspar and albite at $200{ }^{\circ} \mathrm{C}$ but when heated to $400{ }^{\circ} \mathrm{C}$ are only in equilibrium with albite (sodic fenite). 


\section{HFSE mineralization}

\section{Magmatic concentration}

Earlier in the discussion, we noted that as the REE are incompatible under most igneous conditions, they are readily incorporated in magmas like carbonatites, which are the products of very small degrees of partial melting, extreme fractionation or liquid immiscibility. As the compatibility of an element in a melt is controlled largely by its charge/radius ratio (i.e., Z/r), we can also predict that the LREE will be more incompatible than the HREE because of their larger radii (with the exception of Ce and Eu, which also can occur as +4 and +2 , respectively, the REE occur exclusively as $3+$ ions) and will therefore concentrate preferentially in carbonatites. The importance of magmatic processes in concentrating the REE in carbonatites has been demonstrated at Mountain Pass (California), where magmatic bastnäsite-(Ce) and monazite-(Ce) are the main REE-bearing minerals (Castor, 2008). However, although magmatic processes undoubtedly enriched the Wicheeda Carbonatite in the REE, the textural observations discussed below, show clearly that the REE mineralization, which is concentrated largely in the dolomite carbonatite, is hydrothermal in origin. By contrast, the occurrence of niobium as small euhedral crystals disseminated in the calcite carbonatite (as inclusions in calcite) provides compelling evidence that the niobium mineralization is entirely magmatic in origin. We conclude that the dominance of magmatic processes in causing the niobium mineralization and the limited role of magmatic processes in the REE mineralization reflect the very low solubility of $\mathrm{Nb}$ in carbonatite magmas and the much 
greater solubility of the REE in these magmas (see Jones and Wyllie, 1983 for evidence of the latter).

\section{Hydrothermal Transport}

Carbonatite magmas exsolve aqueous fluids, which are commonly enriched in $\mathrm{F}^{-}, \mathrm{CO}_{2}$, $\mathrm{SO}_{4}{ }^{2}$, and $\mathrm{PO}_{4}{ }^{3-}$, ligands that can potentially mobilize the REE and alter the adjacent host rocks (Currie and Ferguson, 1971; Kresten and Morogan, 1986; Gittins et al., 1990; Bühn and Rankin, 1999; Williams-Jones and Palmer, 2002). The behavior of the REE in hydrothermal systems containing these anions is readily predicted by hard-soft acid-base principles (Pearson, 1963). These principles predict that, in the case of monovalent anions, the REE should form their most stable aqueous complexes with $\mathrm{F}^{-}$followed by $\mathrm{OH}^{-}, \mathrm{NO}_{3}{ }^{-}$and $\mathrm{Cl}^{-}$. In the case of the divalent anions, the order is $\mathrm{CO}_{3}{ }^{2-}>\mathrm{SO}_{4}{ }^{2-}>\mathrm{PO}_{4}{ }^{3-}$. This is supported by recent experimental studies (e.g., Migdisov and Williams-Jones, 2002; 2007; 2008; Migdisov et al., 2009). At low pH, fluoride activity is very low because $\mathrm{HF}$ is a weak acid, and at higher $\mathrm{pH}$ fluoride activity is buffered to very low values because of the very low solubility of REE-fluoride minerals. Consequently, this precludes the transport of the REE as fluoride complexes (Williams-Jones et al., 2012). However, relatively high concentrations of the REE can be transported as REE-chloride complexes at low $\mathrm{pH}$ in fluids with salinities typical of those exsolving from carbonatite magmas and at higher $\mathrm{pH}$ as REE-sulphate complexes from sulphate-rich fluids (Williams-Jones et al., 2012). By contrast $\mathrm{F}^{-}$acts as a depositional ligand, promoting the formation of minerals like bastnäsite-(Ce) (Williams-Jones et al., 2012). 


\section{REE-mineral precipitation}

In the preceding section, we summarized our current understanding of the transport of REE by hydrothermal fluids. Here, we consider the controls on REE mineral deposition. The most important of REE mineral in the Wicheeda Carbonatite is bastnäsite-(Ce) $\left(\mathrm{REECO}_{3} \mathrm{~F}\right)$ which forms via the reaction:

$$
\mathrm{REECl}^{2+}+\mathrm{HF}+\mathrm{HCO}_{3}{ }^{-}=\mathrm{REECO}_{3} \mathrm{~F}+2 \mathrm{H}^{+}+\mathrm{Cl}^{-}
$$

According to this reaction, bastnäsite-(Ce) deposition is favored by a high activity of HF and $\mathrm{HCO}_{3}{ }^{-}$and high $\mathrm{pH}$. Interaction of acidic REE-bearing hydrothermal fluids with carbonate rocks would be particularly effective in increasing $\mathrm{aHCO}_{3}{ }^{-}$and $\mathrm{pH}$ as a result of the reaction:

$$
2 \mathrm{H}^{+}+\mathrm{CaMg}\left(\mathrm{CO}_{3}\right)_{2}=\mathrm{Ca}^{2+}+\mathrm{Mg}^{2+}+2 \mathrm{HCO}_{3}{ }^{-}
$$

Unfortunately, thermodynamic data are currently lacking for bastnäsite-(Ce) and we are therefore unable to quantitatively evaluate its deposition. Another important REE mineral in the carbonatite, for which thermodynamic data are available, is monazite-(Ce). We modeled its formation by interacting a hypothetical REE-brine containing $10 \mathrm{wt} . \%$ $\mathrm{NaCl}$ (cf. Smith and Henderson, 2000; Williams-Jones et al., 2000) with dolomite carbonatite using the HCh equilibrium modeling software package (Shvarov, 2013). The carbonatite was assumed to contain $1 \mathrm{wt} . \%$ apatite in order to provide a source for 
phosphorus. The initial temperature of the fluid was $400{ }^{\circ} \mathrm{C}$ (similar to that at Bayan Obo; Smith and Henderson, 2000), the $\mathrm{pH} 2.5$ and the initial Ce content was $100 \mathrm{ppm}$. Thermodynamic data for monazite-(Ce) were taken from Popa et al. (2007) and for the aqueous Ce species from Migdisov et al. (2009). The fluid was cooled to $300{ }^{\circ} \mathrm{C}$ as milligram aliquots of carbonatite were added to $1 \mathrm{~kg}$ of REE-bearing fluid to simulate the reaction.

Reaction of carbonatite with the fluid consumed dolomite leading to a minor increase in pH (Fig. 31A) and also consumed apatite, adding phosphorus to the solution, which reacted with the dissolved cerium to produce monazite-(Ce). Owing to the very low solubility of monazite-(Ce) under the model conditions, the concentration of $\mathrm{Ce}$ in solution dropped sharply and at $340^{\circ} \mathrm{C}$, after addition of only $1200 \mathrm{mg}$ of apatite, more than $99 \%$ of the Ce initially in solution had been deposited as monazite-(Ce) (Fig. 31B). The model elegantly explains the intimate spatial association of the fluorapatite-bearing xenoliths with monazite-(Ce) and Dolomite 3 (e.g. Fig. 9E) in the Wicheeda Carbonatite. 

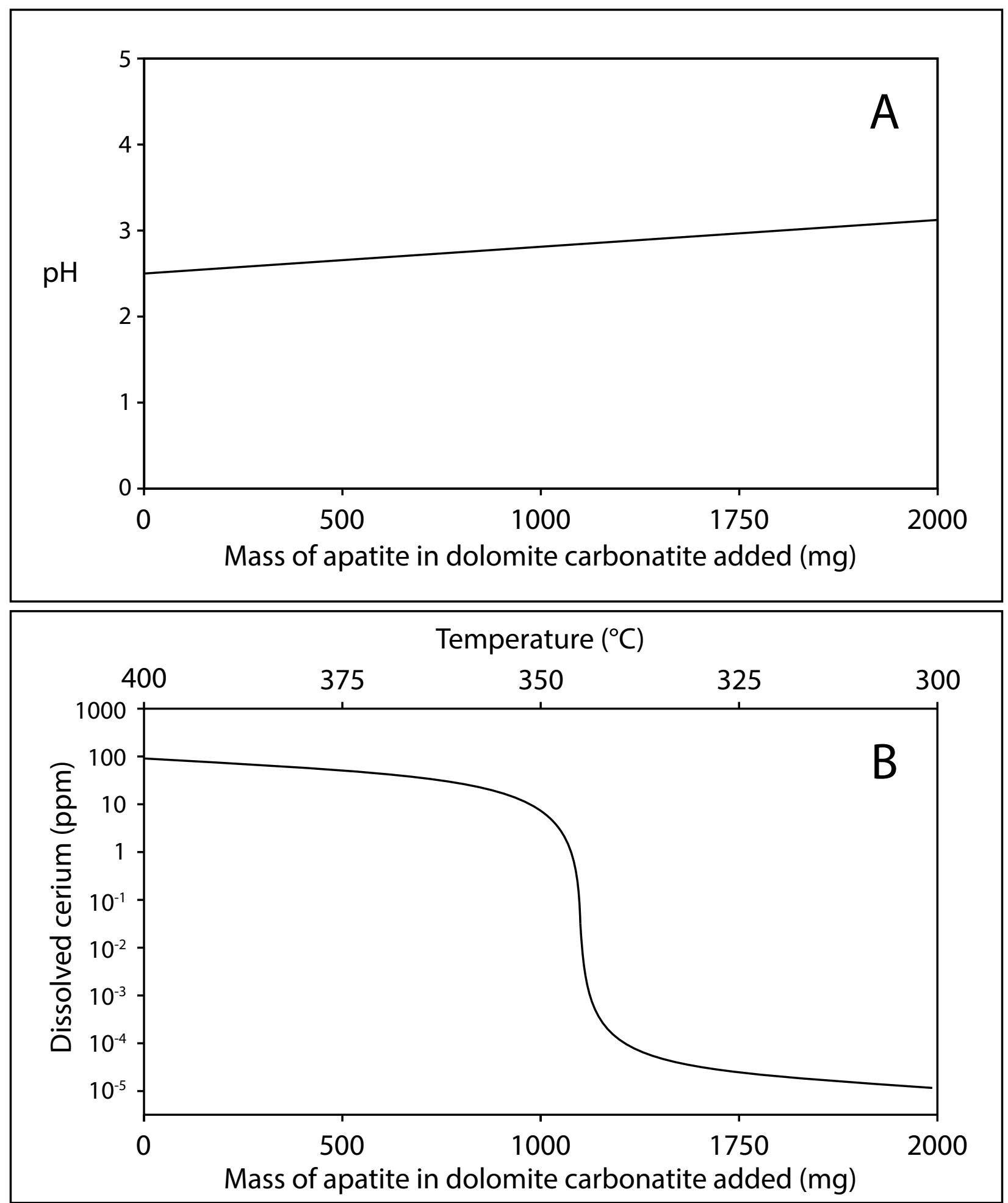

Fig. 31: Results of a model in which a hydrothermal fluid containing $10 \mathrm{wt} . \% \mathrm{NaCl}$ and $100 \mathrm{ppm}$ Ce reacted with apatite-bearing dolomite carbonatite ( $1 \mathrm{wt} . \%$ apatite) to form monazite-(Ce) while cooling from 400 to $300{ }^{\circ} \mathrm{C}$. A. A plot of $\mathrm{pH}$ versus the mass of apatite in dolomite carbonatite (mg) added to the fluid. B. A plot of dissolved cerium concentration (mg) versus the mass of apatite in dolomite carbonatite $(\mathrm{mg})$ added to the fluid. See the main text for details of the calculations. 


\section{Comparison to the REE mineralization in the Prince Claim Block}

Earlier in this paper, we mentioned that carbonatite intrusions with sporadic REE mineralization (mainly dikes and sills) and associated alkaline intrusions are found immediately to the southeast of the main Wicheeda Carbonatite (George claims). Dalsin et al. (2015) studied these dikes and reported the occurrence of calcio- to ferruginous calcio-carbonatites comprising calcite, ankerite, and minor dolomite. The small amount of REE mineralization observed in the dikes occurs mainly as very fine-grained aggregates with calcite and strontianite, in which monazite-(Ce) was the earliest phase to form and is intergrown with later Ca-REE-fluorocarbonates and Ba-REEfluorocarbonates. Dalsin et al. (2015) interpreted the aggregates, and the REEfluorocarbonates in particular, to represent eutectic crystallization during rapid cooling of the dikes. Although we cannot rule out this possibility, the textures illustrated in their Figure 6 (e.g., Fig. 6b) and their description of Ca-REE fluorocarbonate minerals infilling fractures together with the occurrence of euhedral bastnäsite-(Ce) "more commonly ...in rocks that are slightly altered" seems more consistent with a hydrothermal origin for the REE mineralization, as we have proposed for the Wicheeda Carbonatite. We thus consider it possible that the aggregates described by Dalsin et al. (2015) may represent vug fillings similar to those in the Wicheeda Carbonatite, and note that such aggregates (involving parasite, synchysite and bastnäsite) have been reported for the Bear Lodge carbonatite by Moore et al. (2015) and interpreted by them to fill miarolitic cavities and be hydrothermal or carbo-hydrothermal in origin. 


\section{Genetic Model}

The Wicheeda Carbonatite is part of a NW-SE trending series of carbonatite and syenite plugs, dikes, and sills that make up the Wicheeda Carbonatite complex. Carbonatites in the complex vary from calcio- to ferro-carbonatites. To the southeast, they are predominantly calcitic, whereas the plug to the northwest (the focus of this study) comprises a marginal calcite facies and a dolomitic core. The occurrence of calcite carbonatite at the margin of the Wicheeda Carbonatite suggests that it represents the earliest magmatic phase to crystallize, an interpretation that is supported by experimental studies of phase relationships in the system $\mathrm{CaO}-\mathrm{MgO}-\mathrm{FeO}$ (Byrnes and Wyllie, 1983; Shatskiy et al., 2014) and carbon/oxygen isotopic data (Fig. 28). As the calcite carbonatite cooled, it saturated relatively early in niobium and crystallized primary pyrochlore. This was followed by intrusion of dolomite carbonatite with a more evolved carbon and oxygen isotopic composition (Fig. 28). Sometime after emplacement, the dolomite carbonatite exsolved an aqueous-carbonic fluid, evident as very small fluid inclusions in Dolomite 2, which mobilized the REE into vugs and veins, and altered the adjacent host rocks to potassic fenite. Distal to the carbonatite, this fluid mixed locally with formational waters that had been heated by the intrusive activity. The latter fluids produced sodic fenite further from the intrusion. As the exsolving fluid, which is interpreted to have been highly acidic, interacted with the carbonatite, it fractured and partially dissolved the host dolomite, creating vugs; the vugs may also represent miarolitic cavities. Barite, molybdenite, pyrite, thorite, and monazite-(Ce) were the earliest fracture and vug filling minerals to form. With progressive fluid-rock interaction cordylite-(Ce) replaced barite, and was in turn replaced by ancylite-(Ce). As the supply 
of $\mathrm{Ba}$ and $\mathrm{Sr}$ from the barite was exhausted, they were followed by precipitation of bastnäsite- $(\mathrm{Ce})$ and later parisite- $(\mathrm{Ce})$ and synchysite- $(\mathrm{Ce})$. Whether there were primary magmatic REE minerals is unknown. However, all the observable REE mineralization is clearly hydrothermal and is interpreted to be the product of the transport of the REE as chloride complexes in highly acidic aqueous-carbonic fluids and the precipitation of REE minerals in response to the increase in $\mathrm{pH}$, which accompanied interaction of these fluids with the dolomite carbonatite. Monazite-(Ce) deposited in response to an increase in phosphate activity due to dissolution of fluorapatite-bearing xenoliths in the dolomite carbonatite. 


\section{References}

Armstrong, J. E., Hoadley, J. W., Muller, J. E., and Tipper, H. W., 1969, Geology, McLeod Lake Map Area (93J), Geological Survey of Canada, p. Map 1204A.

Betmanis, A. I., 1987, Report on geological, geochemical and magnetometer surveys on the Prince and George groups, cariboo mining division, in British Columbia Ministry of Energy, Mines, and Petroleum Resources, p. 1-86.

Bruland, T., 2011, 2010 Diamond drilling on Carbo rare earth element property, p. 5-31.

Bühn, B., Rankin, A.H., 1999, Composition of natural, volatile-rich Na-Ca-REE-Sr carbonatitic fluids trapped in fluid inclusions, Geochimica et Cosmochimica Acta, v. 63, p. 3781-3797.

Bühn, B., Rankin, A.H., Schneider, J., Dulski, P., 2002, The nature of orthomagmatic, carbonatitic fluids precipitating REE,Sr-rich fluorite: fluid inclusion evidence from the Okorusu fluorite deposit, Namibia, Chemical Geology, v. 186, p. 79-98.

Byrnes, A. P., and Wyllie, P. J., 1981, Subsolidus and melting relations for the join $\mathrm{CaCO}_{3}-\mathrm{MgCO}_{3}$ at 6 kbar: Geochimica et Cosmochimica Acta, v. 45, p. 321-328.

Castor, S. B., 2008, The mountain pass rare-earth carbonatite and associated ultrapotassic rocks, California: Canadian Mineralogist, v. 46, p. 779-806.

Chacko, T., Mayeda, T. K., Clayton, R. N., and Goldsmith, J. R., 1991, Oxygen and carbon isotope fractionation between $\mathrm{CO}_{2}$ and calcite: Geochimica et Cosmochimica Acta, v. 55, p. 2867-2882.

Currie, K. L., and Ferguson, J., 1971, A study of fenitization around the alkaline carbonatite complex at Callander Bay, Ontario, Canada: Canadian Journal of Earth Sciences, v. 8, p. 498-517.

Dalsin, M. L., and Groat, L. A., 2011, The geology and mineralogy of the Carbo property, Wicheeda Carbonatite Complex, BC, Roundup 2011: Vancouver, BC.

Dalsin, M. L., Groat, L. A., Creighton, S., and Evans, R. J., In press, The mineralogy and geochemistry of the Wicheeda Carbonatite Complex, British Columbia Canada: Ore Geology Reviews, v. 64, p. 523-542.

Deines, P., 1989, Stable isotope variations in carbonatites, in Bell, K., ed., Carbonatites Genesis and Evolution: London, UK, Unwin Hyman Ltd., p. 301-359.

Doroshkevich, A. G., Viladkar, S. G., Ripp, G. S., and Burtseva, M. V., 2009, Hydrothermal REE mineralization in the Amba Dongar carbonatite complex, Gujarat, India: The Canadian Mineralogist, v. 47, p. 1105-1116. 
Eggler, D. H., 1974, Effect of $\mathrm{CO}_{2}$ on the melting of peridotite: Carnegie Institution of Washington Yearbook, v. 73, p. 215-224.

Eggler, D. H., 1978, The effect of $\mathrm{CO}_{2}$ upon partial melting of peridotite in the system $\mathrm{Na}_{2} \mathrm{O}-\mathrm{CaO}-\mathrm{Al}_{2} \mathrm{O}_{3}-\mathrm{MgO}-\mathrm{SiO}_{2}-\mathrm{CO}_{2}$ to $35 \mathrm{~kb}$, with an analysis of melting in a peridotite- $\mathrm{H}_{2} \mathrm{O}-\mathrm{CO}_{2}$ system: American Journal of Science, v. 278, p. 305-343.

Eggler, D. H., 1989, Carbonatites, primary melts, and mantle dynamics, in Bell, K., ed., Carbonatites, Genesis and Evolution: London, UK, Unwin Hyman Ltd., p. 561579.

Fortin-Bélanger, M., 1977, Le complexe annulaire, à carbonatite de St.-Honoré (P.Q., Canada) et sa minéralisation à niobium: étude pétrographique et géochimique, Université Claude Bernard, 308 p.

Fournier, A., 1993, Magmatic and hydrothermal controls of LREE mineralization of the St. Honoré carbonatite, Quebec: Unpub. Manuscript thesis, McGill University, $147 \mathrm{p}$.

Freestone, I. C., and Hamilton, D. L., 1980, The role of liquid immiscibility in the genesis of carbonatites - an experimental study: Contributions to Mineralogy and Petrology, v. 73, p. 105-117.

Gittins, J., Beckett, M. F., and Jago, B. C., 1990, Composition of the fluid phase accompanying carbonatite magma: a critical examination.: American Mineralogist, v. 75, p. 1106-1109.

Gittins, J., and Harmer, R. E., 1997, What is ferrocarbonatite? A revised classification: Journal of African Earth Sciences, v. 25, p. 159-168.

Hamilton, D. L., Bedson, P., and Esson, J., 1989, The behaviour of trace elements in the evolution of carbonatites, in Bell, K., ed., Carbonatites, Genesis and Evolution: London, UK, Unwin Hyman Ltd.

Hawthorne, F. C., Oberti, R., Harlow, G. E., Maresch, W. V., Martin, R. F., Schumacher, J. C., and Welch, M. D., 2012, Nomenclature of the amphibole supergroup: American Mineralogist, v. 97, p. 2031-2048.

Horita, J., 2014, Oxygen and carbon isotope fractionation in the system dolomite-water$\mathrm{CO}_{2}$ to elevated temperatures: Geochimica et Cosmochimica Acta, v. 129, p. 111124.

Irving, A. J., and Wyllie, P. J., 1975, Subsolidus and melting relationships for calcite magnesite and the join $\mathrm{CaCO}_{3}-\mathrm{MgCO}_{3}$ to 36 kbar: Geochimica et Cosmochimica Acta, v. 39, p. 35-53. 
Jago, B. C., and Gittins, J., 1993, Pyrochlore crystallization in carbonatites: the role of fluorine: South African Journal of Geology, v. 96, p. 149-159.

Jones, A. P., and Wyllie, P. J., 1983, Low-temperature glass quenched from a synthetic, rare earth carbonatite: implications for the origin of the Mountain Pass Deposit, California: Economic Geology, v. 78, p. 1721-3.

Jones, A. P., and Wyllie, P. J., 1986, Solubility of rare earth elements in carbonatite magmas, indicated by the liquidus surface in $\mathrm{CaCO}_{3}-\mathrm{Ca}(\mathrm{OH})_{2}-\mathrm{La}(\mathrm{OH})_{3}$ at $1 \mathrm{kbar}$ pressure: Applied Geochemistry, v. 1, p. 95-102.

Keller, J., and Hoefs, J., 1995, Stable isotope characteristics of recent natrocarbonatites from Oldoinyo Lengai, IAVCEI Proceedings Volcanology.

Kjarsgaard, B. A., and Hamilton, 1988, Liquid immiscibility and the origin of alkali-poor carbonatites: Mineralogical Magazine, v. 52, p. 43-55.

Kresten, P., 1988, The chemistry of fenitization: examples from Fen, Norway: Chemical Geology, v. 68, p. 329-349.

Kresten, P. and V. Morogan, 1986, Fenitization at the Fen complex, southern Norway, Lithos, v. 19, p. 27-42.

Lagache, M. and A. Weisbrod, 1977, The system: two alkali feldspars-KCl-NaCl- $\mathrm{H}_{2} \mathrm{O}$ at moderate to high temperatures and low pressures: Contributions to Mineralogy and Petrology, v. 62, p. 77-101.

Lane, R., 2009, Diamond drilling report on the Wicheeda property, p. 1-196.

Lane, R., 2010, 2009 Diamond drilling report on the Wicheeda rare earth property, p. 129.

Le Bas, M. J., 1977, Carbonatite-Nephelinite Volcanism: London, Wiley.

Le Bas, M. J., 1981, Carbonatite magmas: Mineralogical Magazine, v. 44, p. 133-140.

Lee, W.-J., and Wyllie, P. J., 1998, Processes of crustal carbonatite formation by liquid immiscibility and differentiation, elucidated by model systems: Journal of Petrology, v. 39, p. 2005-2013.

Mäder, U. K., and Greenwood, H. J., 1987, Carbonatites and related rocks of the Prince and George claims, northern rocky mountains (93I; 93J), Geological Fieldwork 1987, British Columbia Ministry of Energy, Mines and Petroleum Resources. 
Migdisov, A., and Williams-Jones, A. E., 2002, A spectrophotometric study of neodymium(III) complexation in chloride solutions: Geochimica et Cosmochimica Acta, v. 66, p. 4311-4323.

Migdisov, A., and Williams-Jones, A. E., 2007, An experimental study of the solubility and speciation of neodymium (III) fluoride in F-bearing aqueous solutions: Geochimica et Cosmochimica Acta, v. 71, p. 3056-3069.

Migdisov, A., and Williams-Jones, A. E., 2008, spectrophotometric study of $\mathrm{Nd}(\mathrm{III})$, $\mathrm{Sm}(\mathrm{III})$, and $\operatorname{Er}$ (III) complexation in sulfate-bearing solutions at elevated temperatures: Geochimica et Cosmochimica Acta, v. 72, p. 5291-5303.

Migdisov, A., Williams-Jones, A. E., and Wagner, T., 2009, An experimental study of the solubility and speciation of the Rare Earth Elements (III) in fluoride- and chloride-bearing aqueous solutions at temperatures up to $300{ }^{\circ} \mathrm{C}$ : Geochimica et Cosmochimica Acta, v. 73, p. 7087-7109.

Millonig, L. J., Gerdes, A., and Groat, L. A., 2012, U-Th-Pb geochronology of metacarbonatites and meta-alkaline rocks in the southern Canadian Cordillera: A geodynamic perspective: Lithos, v. 152, p. 202-217.

Mitchell, R. H., and Kjarsgaard, B. A., 2002, Solubility of niobium in the system $\mathrm{CaCO}_{3}$ $\mathrm{Ca}(\mathrm{OH})_{2}-\mathrm{NaNbO}_{3}$ at $0.1 \mathrm{GPa}$ pressure: Contributions to Mineralogy and Petrology, v. 144, p. 93-97.

Mitchell, R. H., and Kjarsgaard, B. A., 2004, Solubility of niobium in the system $\mathrm{CaCO}_{3}$ $\mathrm{CaF}_{2}-\mathrm{NaNbO}_{3}$ at $0.1 \mathrm{GPa}$ pressure: implications for the crystallization of pyrochlore from carbonatite magma: Contributions to Mineralogy and Petrology, v. 148, p. 281-287.

Möller, P., Morteani, G., and Schley, F., 1980, Discussion of REE distribution patterns of carbonatites and alkalic rocks: Lithos, v. 13, p. 171-179.

Monger, J. W. H., Gabrielse, H., and Souther, J. G., 1972, Evolution of the Canadian Cordillera: a plate-tectonic model: American Journal of Science, v. 272, p. 577602.

Monger, J. W. H., and Price, R. A., 1979, Geodynamic evolution of the Canadian Cordillera - progress and problems: Canadian Journal of Earth Sciences, v. 16, p. 770-791.

Monger, J.W.H., 1989, Chapter 2, Overview of Cordilleran Geology, in Ricketts, B.D., ed., Western Canada Sedimentary Basin: A Case History: Calgary, Canadian Society of Petroleum Geologists, p. 9-32. 
Moore, M., Chakhmouradian, A. R., Mariano, A. N., and Sidhu, R., In press, Evolution of rare-earth mineralization in the Bear Lodge carbonatite, Wyoming: Mineralogical and isotopic evidence: Ore Geology Reviews, v. 64, 499-521.

Morimoto, N. Fabries, J., Ferguson, A.K., Ginzburg, I.V., Ross, M., Seifert, F.A., Zussman, J., Aoki, K, and G. Gottardi, 1988, Nomenclature of Pyroxenes: Mineralogy and Petrology, v. 39, p. 55-76.

Pearson, R. G., 1963, Hard and soft acids and bases: Journal of the American Chemical Society, v. 85, p. 3533-3539.

Pell, J., 1994, Carbonatites, nepheline syenites, kimberlites and related rocks in British Columbia, British Columbia Ministry of Energy, Mines and Petroleum Resources, p. 1-44.

Pineau, F., Javoy, M., and Allégre, C. J., 1973, Etude systématique des isotopes de l'oxygéne, du carbone et du strontium dans les carbonatites: Geochimica et Cosmochimica Acta, v. 37, p. 2363-2377.

Popa, K., Konings, R. J. M., and Geisler, T., 2007, High-temperature calorimetry of (La L- $_{1-}$ $\left.{ }_{x} \mathrm{Lnx}\right) \mathrm{PO}_{4}$ solid solutions: Journal of Chemical Thermodynamics, v. 39, p. 236239.

Ray, J. S., and Ramesh, R., 2000, Rayleigh fractionation of stable isotopes from a multicomponent source: Geochimica et Cosmochimica Acta, v. 64, p. 299-306.

Richet, P., Bottinga, Y., and Javoy, M., 1977, A review of hydrogen, carbon, nitrogen, oxygen, sulphur, and chlorine stable isotope fractionation among gaseous molecules: Annual Review of Earth and Planetary Sciences, p. 65-110.

Rieder, M., Cavazzini, G., D’Yakonov, Y.S., Frank-Kamenetskii, V.A., Gottardi, G., Guggenheim, S., Koval, P.V., Müller, G., Neiva, A.M.R., Radoslovich, E.W., Robert, J-L., Sassi, F.P., Takeda, H., Weiss, Z., and Wones, D.R., 1998, Nomenclature of the micas, The Canadian Mineralogist, 36, p. 905-912.

Rosenbaum, J. M., 1994, Stable isotope fractionation between carbon dioxide and calcite at $900^{\circ} \mathrm{C}$ : Geochimica et Cosmochimica Acta, v. 58, p. 3747-3753.

Salvi, S., and Williams-Jones, A.E., 1990, The role of hydrothermal processes in the granite-hosted zirconium, yttrium, REE deposit at Strange Lake, Quebec/Labrador: evidence from fluid inclusions: Geochimica et Cosmochimica Acta, v. 54, p. 2403-2418.

Sears, J.W., Price, R.A., 1978, The Siberian connection- a case for Precambrian separation of the North American and Siberian cratons, Geology, v. 6, p. 267-270. 
Shatskiy, A., Borzdov, Y.M., Litasov, K.D., Kupriyanov, I.N., Ohtani, E., Palyanov, Y.N., 2014, Phase relations in the system $\mathrm{FeCO}_{3}-\mathrm{CaCO}_{3}$ at $6 \mathrm{GPa}$ and 900-1700 ${ }^{\circ} \mathrm{C}$ and its relation to the system $\mathrm{CaCO}-\mathrm{FeCO}_{3}-\mathrm{MgCO}_{3}$, American Mineralogist, v. 99, 773-785.

Shvarov, Y., 2013, HCh for Windows, A software package for thermodynamic modeling. http://www.geol.msu.ru/deps/geochems/soft/index_e.html

Smith, M. P., and Henderson, P., 2000, Preliminary fluid inclusion constraints on fluid evolution in the Bayan Obo Fe-REE-Nb deposit, inner Mongolia, China: Economic Geology, v. 95, p. 1371-1388.

Taylor, G. C., and Stott, D. F., 1979, Geology, Monkman Pass Map Area, British Columbia (93I), Geological Survey of Canada, p. Open File Map 630.

Taylor, H. P. J., Frechen, J., and Degens, E. T., 1967, Oxygen and carbon isotope studies of carbonatites from the Laacher See District, West Germany, and the Alnö District, Sweden: Geochimica et Cosmochimica Acta, v. 31, p. 407-430.

Van Straaten, P., 1989, Nature and structural relationships of carbonatites from southwest and west Tanzania, in Bell, K., ed., Carbonatites, Genesis and Evolution: London, UK, Unwin Hyman Ltd., p. 177-199.

von Eckermann, H., 1948, The alkaline district of Alnö island: Sveriges Geologiska Undersökning, v. 36, p. 1-176.

Wall, F., and Mariano, A. N., 1996, Rare earth minerals in carbonatites: a discussion centred on the Kangankunde Carbonatite, Malawi.: London, Chapman and Hall, 193-225.

Williams-Jones, A. E., Migdisov, A. A., and Samson, I. M., 2012, Hydrothermal Mobilisation of the Rare Earth Elements - a Tale of "Ceria" and "Yttria", Elements, v. 8, 355-360.

Williams-Jones, A. E., and Palmer, D. A. S., 2002, Fluid evolution of the Amba Dongar carbonatite complex, India: Chemical Geology, v. 185, p. 283-301.

Williams-Jones, A. E., Samson, I. M., and Olivo, G. R., 2000, The genesis of hydrothermal fluorite-REE deposits in the Gallinas Mountains, New Mexico: Economic Geology, v. 95, p. 327-342.

Woolley, A. R., and Kempe, D. R. C., 1989, Carbonatites: nomenclature, average chemical compositions, and element distribution, in Bell, K., ed., Carbonatites, Genesis and Evolution: London, UK, Unwin Hyman Ltd., p. 1-13. 
Xu, C., Huang, Z.-L., Liu, C. Q., Qi, L., Li, W.-B., and Guan, T., 2003, Sources of oreforming fluids in the Maoniuping REE deposit, Sichuan Province, China: Evidence from REE, radiogenic $\mathrm{Sr}, \mathrm{Nd}$, and stable-isotopes studies.: International Geology Reviews, v. 45, p. 635-645.

Xu, C., Zhilong, H., Congqiang, L., Liang, Q., Wenbo, L., and Guan, T., 2004, Genesis of the carbonatite-syenite complex and REE deposit at Maoniuping, Sichuan Province, China: Evidence from $\mathrm{Pb}$ isotope geochemistry: Geochemical Journal, v. 38, p. $67-76$.

Zaitsev, A. N., Wall, F., and Le Bas, M. J., 1998, REE-Sr-Ba minerals from the Khibina carbonatites, Kola peninsula, Russia: their mineralogy, paragenesis and evolution: Mineralogical Magazine, v. 62, p. 225-250.

Zaitsev, A. N., Williams, C. T., Jeffries, T. E., Strekopytov, S., Moutte, J., Ivashchenkova, O. V., Spratt, J., Petrov, S. V., Wall, F., Seltmann, R., and Borozdin, A. P., 2014, Rare earth elements in phoscorites and carbonatites of the Devonian Kola Alkaline Province, Russia: Examples from Kovdor, Khibina, Vuoriyarvi and Turiy Mys complexes: Ore Geology Reviews, v. 61, p. 204-225.

Zheng, Y.-F., 1999, Oxygen isotope fractionation in carbonate and sulfate minerals: Geochemical Journal, v. 33, p. 109-126. 
CHAPTER III: Conclusions 


\section{Conclusions}

The Wicheeda Carbonatite comprises a ferroan dolomite core, which passes gradationally into calcite carbonatite at depth and at the margins of the intrusion. It is surrounded by potassic fenite (mainly potassium feldspar) near the intrusion and sodic fenite (albite+aegirine) at greater distances from it. Textural and stable isotopic evidence indicate that calcite carbonatite was the earliest magmatic phase to crystallize. As it cooled, the magma became saturated with respect to niobium and precipitated primary pyrochlore. Some time later, dolomite carbonatite magma was emplaced which, upon cooling, exsolved an aqueous-carbonic fluid, fracturing the carbonatite and altering its isotopic carbon and oxygen composition. On the basis of the carbon and oxygen isotopic data, the alteration took place at a temperature between 300 and $400{ }^{\circ} \mathrm{C}$. This fluid also mobilized REE into fractures and vugs (miarolitic cavities and dissolution cavities), and altered the nearby Kechika Group metasedimentary rocks to potassic fenite. Sodic fenite formed as a result of the mixing of this fluid with formational waters heated by intrusive activity further from the carbonatite. The fractures and vugs in the dolomite carbonatite were filled by hydrothermal dolomite barite, molybdenite, pyrite and REE minerals. Barite was replaced by cordylite-(Ce) and ancylite-(Ce), and these minerals in turn by bastnäsite-(Ce), parisite-(Ce), and synchysite-(Ce).

As is evident from the preceding paragraphs and from Chapter 2, the REE mineralization in the Wicheeda Carbonatite is entirely hydrothermal in origin. This interpretation departs greatly from that proposed by Dalsin et al (2015) for REE mineralization in carbonatite dikes to the south of the main carbonatite intrusion. 


\section{Contributions to Knowledge}

From a local perspective, this study provides an important contribution to one of the most promising REE prospects in the relatively unexplored British Columbia alkaline province. The research undertaken generated the first local geological maps of the intrusion, described the various rock units, and developed a model to explain its magmatic and hydrothermal evolution.

In a broader geological context, the study showed how magmatic hydrothermal fluids alter host rocks to sodic and potassic fenite, and that the concentration of REE by postmagmatic hydrothermal fluid in carbonates, fluorocarbonates, and in monazite-(Ce) is largely dependent on $\mathrm{pH}$ and the availability of $\mathrm{F}$ and $\mathrm{P}$ as depositional ligands. Also in this context, this study demonstrates that rare Sr- and Ba-REE-minerals such as ancylite(Ce) and cordylite-(Ce), are concentrated by hydrothermal processes. Finally, this thesis has provided an important body of information that will help guide further exploration of this intrusion and other similar intrusions elsewhere.

Future research on the Wicheeda Carbonatite should focus on constraining the limits of fenitized haloes and the geometry of the intrusion. Based on existing drill core information, it is a plug-like intrusion with undefined roots and it is likely that these roots are important to better understanding the emplacement and post-emplacement history of the intrusion. Equally important is future research focused on understanding the composition and evolution of the fluids responsible for depositing the REE. 
Appendices 
Appendix A

Locations of outcrops sampled 
Appendix A: Locations of outcrops sampled

\begin{tabular}{|c|c|c|c|c|c|}
\hline $\begin{array}{l}\text { Outcrop } \\
\text { Number }\end{array}$ & $\begin{array}{l}\text { UTM X } \\
\text { Nad } 83\end{array}$ & $\begin{array}{l}\text { UTM Y } \\
\text { Nad } 83\end{array}$ & $\begin{array}{l}\text { Outcrop } \\
\text { Number }\end{array}$ & $\begin{array}{l}\text { UTM X } \\
\text { Nad } 83\end{array}$ & $\begin{array}{l}\text { UTM Y } \\
\text { Nad } 83\end{array}$ \\
\hline WI-13-01 & 0558290 & 6042865 & WI-13-33 & 0558361 & 6043254 \\
\hline WI-13-02 & 0558308 & 6043017 & WI-13-34 & 0558364 & 6043270 \\
\hline WI-13-04 & 0558358 & 6043086 & WI-13-35 & 0558363 & 6043285 \\
\hline WI-13-05 & 0558397 & 6043073 & WI-13-36 & 0558438 & 6043320 \\
\hline WI-13-06 & 0558470 & 6043036 & WI-13-37 & 0558448 & 6043318 \\
\hline WI-13-07 & 0558481 & 6043010 & WI-13-38 & 0558463 & 6043152 \\
\hline WI-13-08 & 0558634 & 6042968 & WI-13-39 & 0558341 & 6042805 \\
\hline WI-13-09 & 0558634 & 6042968 & WI-13-40 & 0558384 & 6042846 \\
\hline WI-13-10 & 0558678 & 6043070 & WI-13-41 & 0558386 & 6042837 \\
\hline WI-13-11 & 0558715 & 6043108 & WI-13-42 & 0558386 & 6042853 \\
\hline WI-13-12 & 0558689 & 6043104 & WI-13-43 & 0558395 & 6042866 \\
\hline WI-13-13 & 0558768 & 6043122 & WI-13-44 & 0558468 & 6042806 \\
\hline WI-13-14 & 0558681 & 6043132 & WI-13-45 & 0558443 & 6042815 \\
\hline WI-13-15 & 0558654 & 6043144 & WI-13-46 & 0558415 & 6042851 \\
\hline WI-13-16 & 0558287 & 6042881 & WI-13-47 & 0558400 & 6042885 \\
\hline WI-13-17 & 0558346 & 6043080 & WI-13-49 & 0558434 & 6043024 \\
\hline WI-13-18 & 0558364 & 6043080 & WI-13-50 & 0558327 & 6042917 \\
\hline WI-13-19 & 0558342 & 6043086 & WI-13-51 & 0558317 & 6042895 \\
\hline WI-13-20 & 0558302 & 6043127 & WI-13-52 & 0558304 & 6042886 \\
\hline WI-13-21 & 0558299 & 6043176 & WI-13-53 & 0558294 & 6042898 \\
\hline WI-13-22 & 0558270 & 6043188 & WI-13-54 & 0558253 & 6042888 \\
\hline WI-13-23 & 0558220 & 6043254 & WI-13-55 & 0558260 & 6042916 \\
\hline WI-13-24 & 0558182 & 6043214 & WI-13-56 & 0558247 & 6042937 \\
\hline WI-13-25 & 0558053 & 6043117 & WI-13-57 & 0558272 & 6043076 \\
\hline WI-13-26 & 0558092 & 6043092 & WI-13-58 & 0558275 & 6043147 \\
\hline WI-13-27 & 0558196 & 6043128 & WI-13-59 & 0558338 & 6043163 \\
\hline WI-13-29 & 0558272 & 6043122 & WI-13-60 & 0558327 & 6043198 \\
\hline WI-13-30 & 0558327 & 6043210 & WI-13-61 & 0558367 & 6043201 \\
\hline WI-13-31 & 0558337 & 6043242 & WI-13-62 & 0558333 & 6043158 \\
\hline WI-13-31a & 0558337 & 6043242 & WI-13-63 & 0558286 & 6043120 \\
\hline WI-13-32 & 0558347 & 6043225 & WI-13-68 & 0557757 & 6043279 \\
\hline
\end{tabular}


Appendix B

Locations of drill cores sampled 
Appendix B: Locations of drill cores sampled

\begin{tabular}{|c|c|c|c|c|c|}
\hline Drill Hole & Sample ID & Depth (m) & Drill Hole & Sample ID & Depth (m) \\
\hline \multirow[t]{15}{*}{$08 \mathrm{WI01}$} & 080101 & 10.4 & WI-09-09 & 090901 & 7.5 \\
\hline & 080102 & 19.1 & & 090902 & 27.1 \\
\hline & 080103 & 22.8 & & 090903 & 27.5 \\
\hline & 080104 & 30.5 & & 090904 & 35.1 \\
\hline & 080105 & 33.0 & & 090905 & 48.4 \\
\hline & 080106 & 42.0 & & 090906 & 52.4 \\
\hline & 080107 & 43.3 & & 090907 & 71.5 \\
\hline & 080108 & 50.5 & & 090908 & 84.4 \\
\hline & 080109 & 61.6 & & 090909 & 84.7 \\
\hline & 080110 & 84.3 & & 090910 & 103.6 \\
\hline & 080111 & 85.2 & & 090911 & 118.4 \\
\hline & 080112 & 88.6 & & 090912 & 146.7 \\
\hline & 080113 & 90.6 & & 090913 & 147.8 \\
\hline & 080114 & 102.7 & WI-09-10 & 091001 & 8.0 \\
\hline & 080115 & 158.3 & & 091002 & 10.0 \\
\hline \multirow[t]{13}{*}{ WI-09-08 } & 090801 & 5.6 & & 091003 & 18.4 \\
\hline & 090802 & 10.6 & & 091004 & 64.1 \\
\hline & 090803 & 17.6 & & 091005 & 74.2 \\
\hline & 090804 & 18.8 & & 091006 & 90.6 \\
\hline & 090805 & 22.0 & & 091007 & 74.2 \\
\hline & 090806 & 27.6 & & 091008 & 93.1 \\
\hline & 090807 & 30.0 & & 091009 & 115.8 \\
\hline & 090808 & 49.0 & & 091010 & 118.5 \\
\hline & 090809 & 90.6 & & 091011 & 120.5 \\
\hline & 090810 & 100.0 & & 091012 & 121.7 \\
\hline & 090811 & 127.7 & & & \\
\hline & 090812 & 134.9 & & & \\
\hline & 090813 & 146.9 & & & \\
\hline
\end{tabular}


Appendix C

Counting times and standards used for each element analyzed with the electron microprobe 
Appendix C: Counting times and standards used for each element analyzed with the electron microprobe

\begin{tabular}{|c|c|c|}
\hline Element & Counting Time & Standard \\
\hline $\mathrm{Al}$ & 20 & cameca orth \\
\hline $\mathrm{Ba}$ & 20 & Ba-feld \\
\hline $\mathrm{Ba}$ & 50 & Ba-feld \\
\hline $\mathrm{Ca}$ & 20 & Cal1 \\
\hline $\mathrm{Ca}$ & 20 & diopside \\
\hline $\mathrm{Ca}$ & 20 & Flap \\
\hline $\mathrm{Ce}$ & 20 & Mac-Ce \\
\hline $\mathrm{Cl}$ & 20 & vana2 \\
\hline Dy & 50 & Mac-Dy \\
\hline $\mathrm{Eu}$ & 100 & Mac-Eu \\
\hline $\mathrm{F}$ & 20 & $\mathrm{CaF} 2$ \\
\hline $\mathrm{F}$ & 20 & Flap \\
\hline $\mathrm{Fe}$ & 20 & $\mathrm{Fe} 2 \mathrm{O} 3$ \\
\hline $\mathrm{Fe}$ & 20 & sid1 \\
\hline $\mathrm{Gd}$ & 50 & Mac-Gd \\
\hline $\mathrm{K}$ & 20 & cameca orth \\
\hline $\mathrm{La}$ & 20 & Mac-La \\
\hline $\mathrm{Mg}$ & 20 & diopside \\
\hline $\mathrm{Mg}$ & 20 & Doll \\
\hline $\mathrm{Mn}$ & 20 & sid1 \\
\hline Mn & 20 & spessartine \\
\hline $\mathrm{Na}$ & 20 & cameca albite \\
\hline $\mathrm{Nb}$ & 20 & $\mathrm{Na} 2 \mathrm{Nb} 2 \mathrm{O} 6$ \\
\hline $\mathrm{Nd}$ & 20 & Mac-Nd \\
\hline $\mathrm{Nd}$ & 50 & Mac-Nd \\
\hline$P$ & 20 & Flap \\
\hline $\mathrm{Pb}$ & 20 & vana 2 \\
\hline $\operatorname{Pr}$ & 50 & Mac-Pr \\
\hline $\mathrm{Rb}$ & 20 & Rb-feld \\
\hline $\mathrm{Si}$ & 20 & cameca orth \\
\hline $\mathrm{Si}$ & 20 & diopside \\
\hline $\mathrm{Sm}$ & 50 & Mac-Sm \\
\hline $\mathrm{Sr}$ & 20 & Sr-feld \\
\hline $\mathrm{Sr}$ & 50 & Sr-feld \\
\hline $\mathrm{Th}$ & 20 & $\mathrm{ThO} 2$ \\
\hline $\mathrm{Th}$ & 100 & ThO2 \\
\hline $\mathrm{Ti}$ & 20 & $\mathrm{tiO} 2$ \\
\hline $\mathrm{Y}$ & 20 & Mac-Y \\
\hline $\mathrm{Zr}$ & 20 & zircon \\
\hline
\end{tabular}




\section{Appendix D}

Results of electron microprobe analyses of dolomite and calcite 


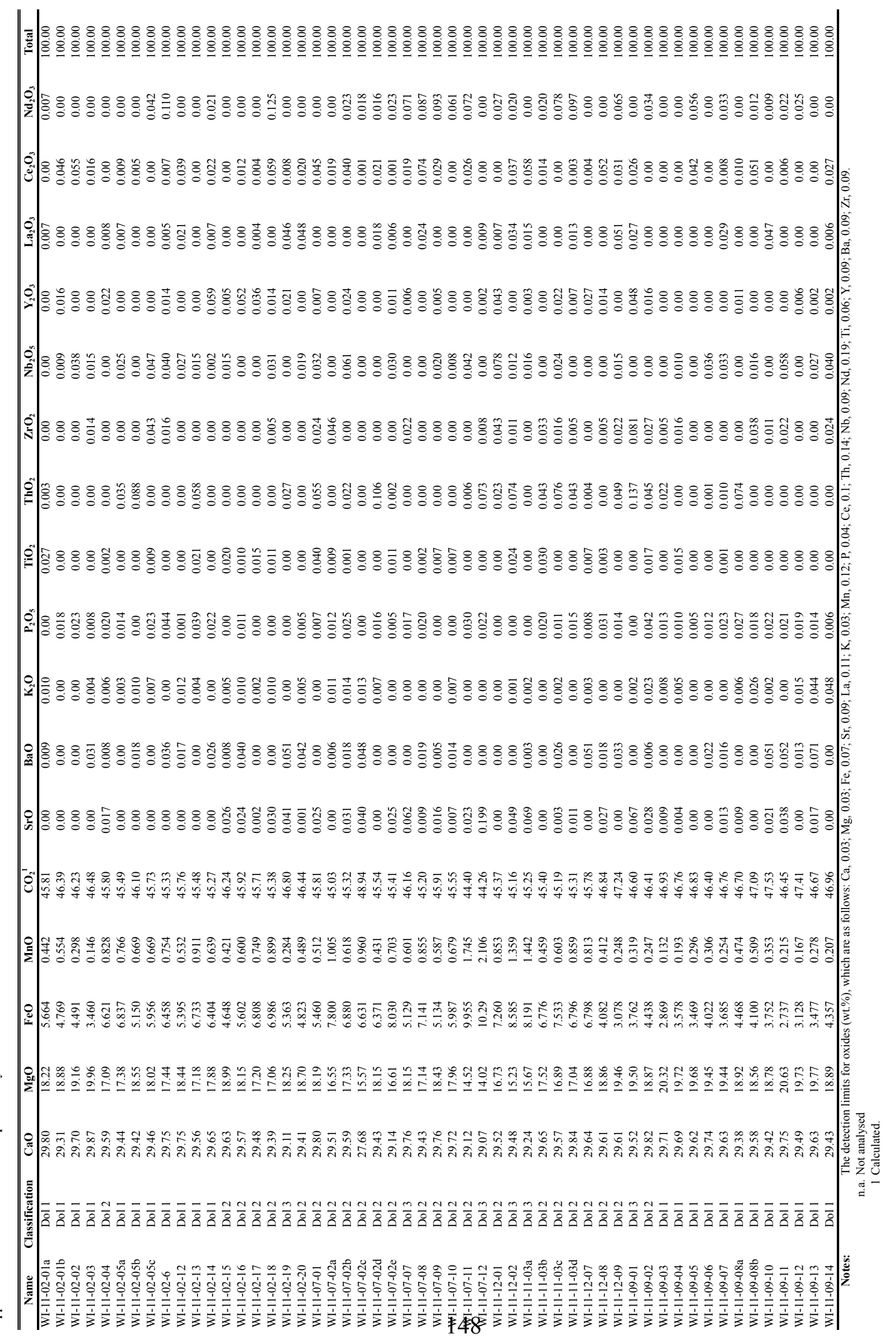




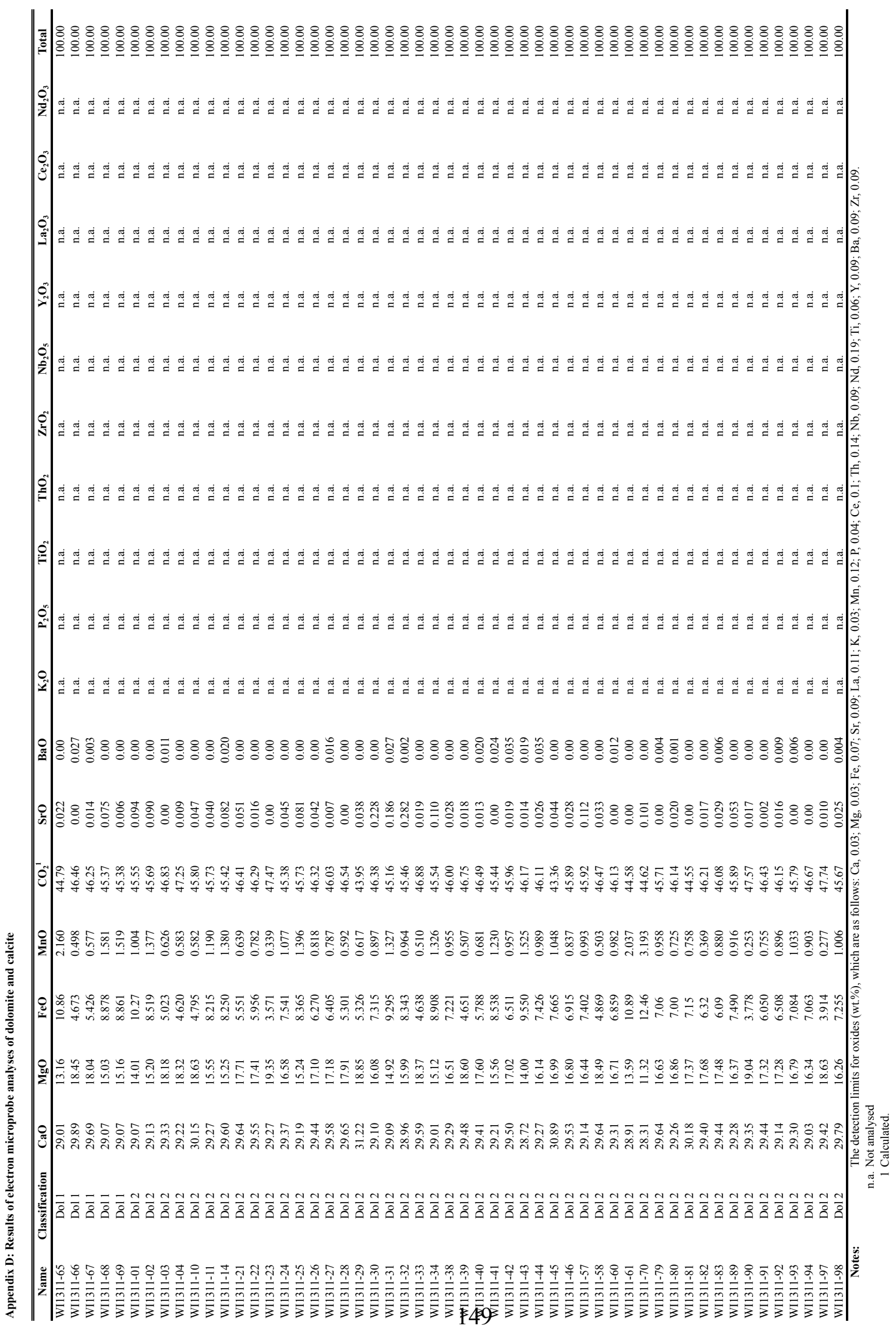




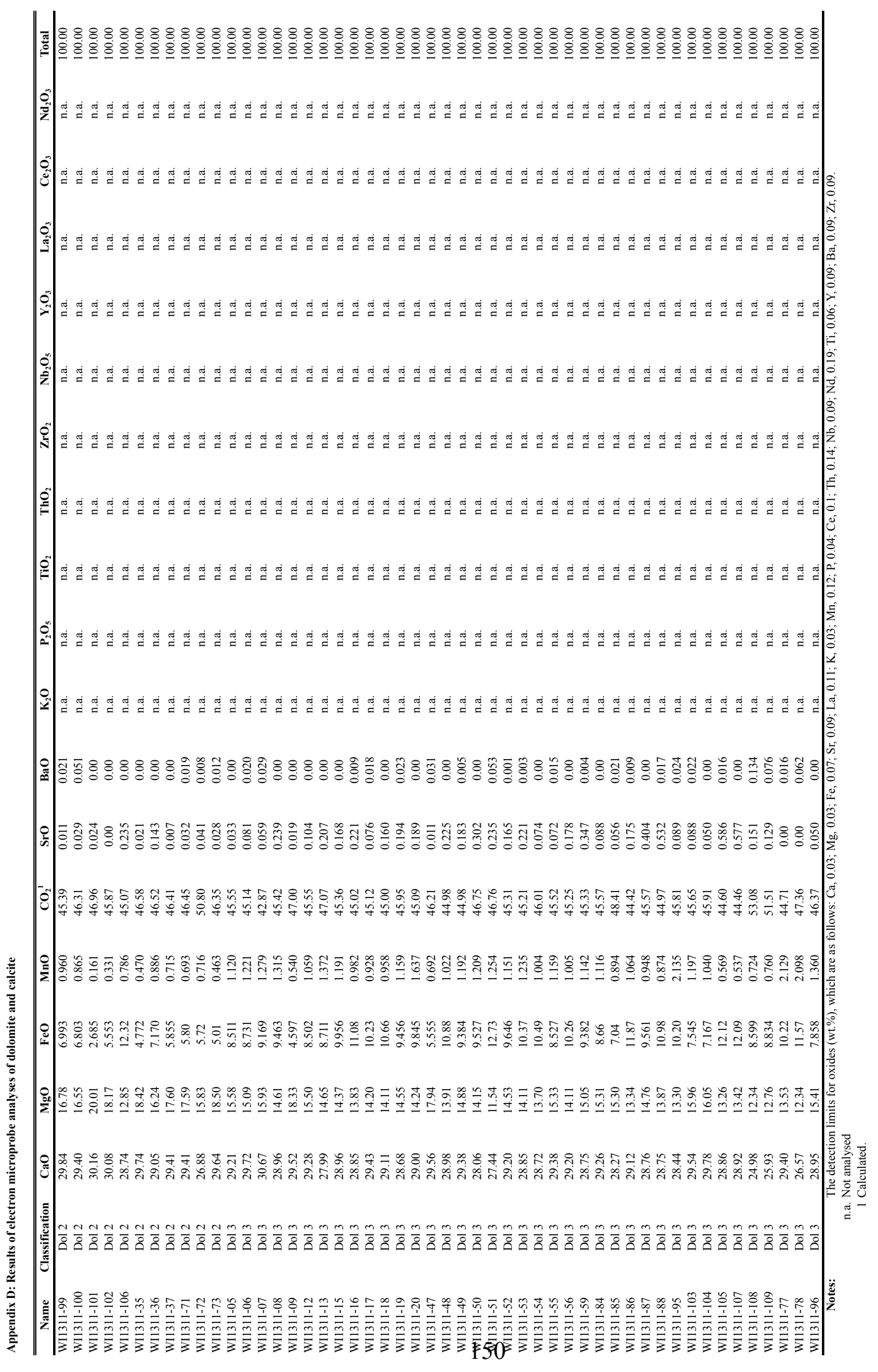




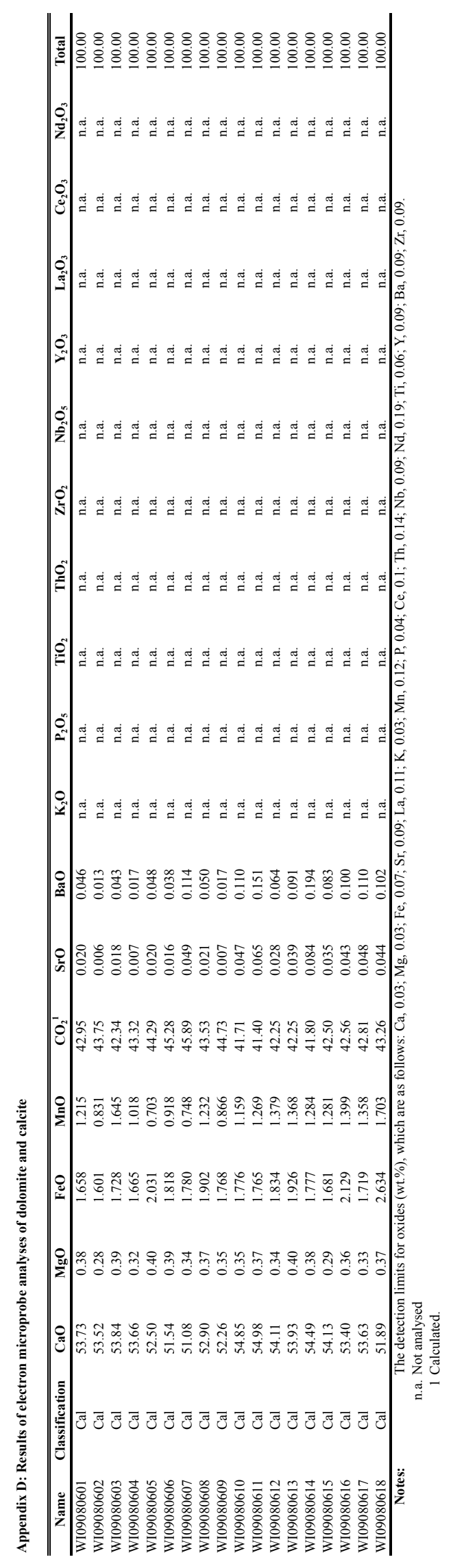


Appendix E

Results of electron microprobe analyses of biotite 


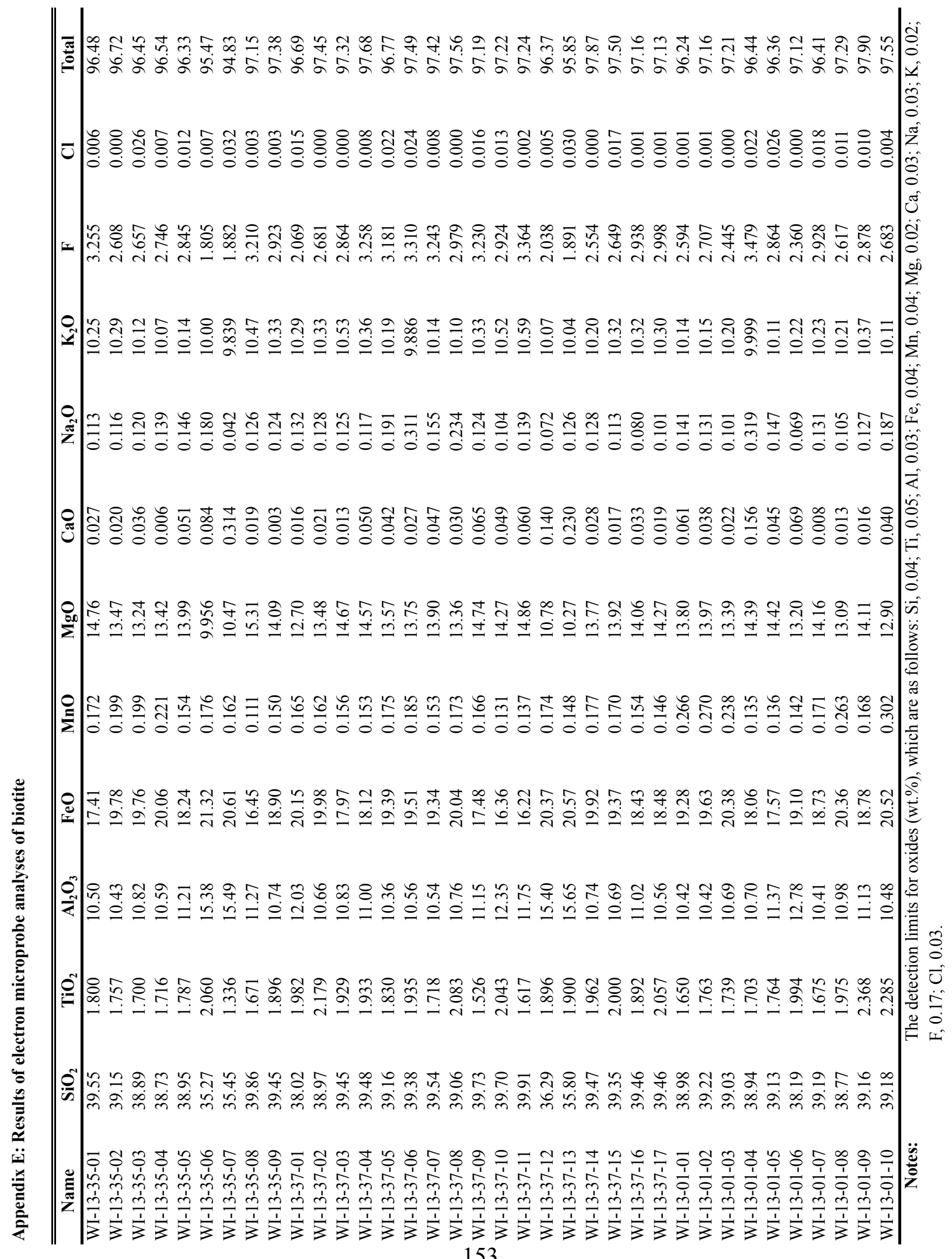




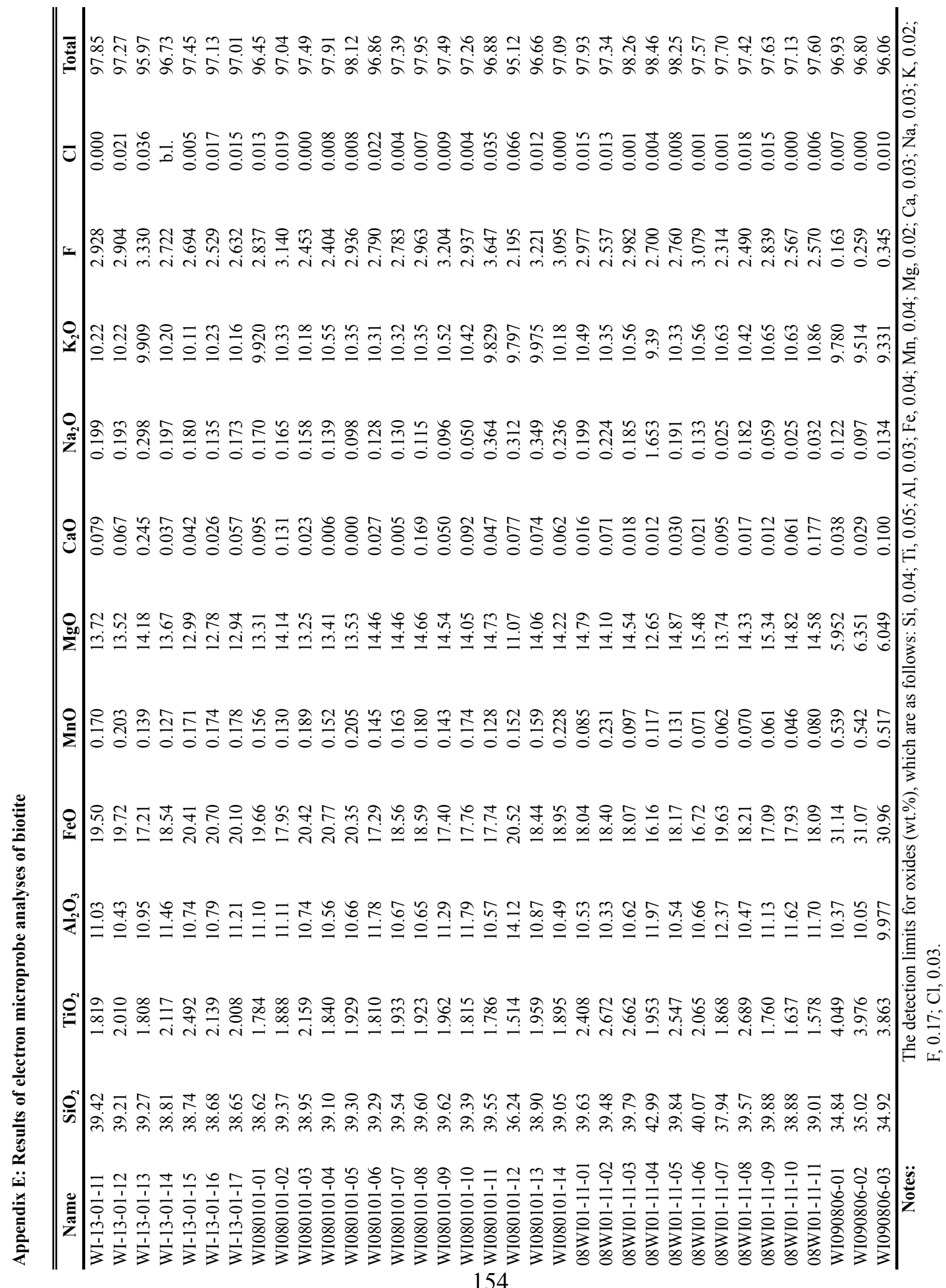




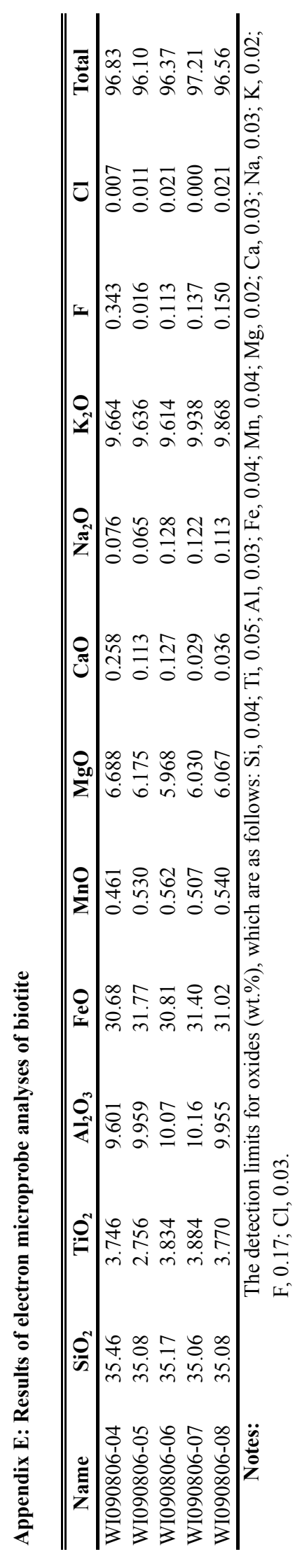




\section{Appendix F \\ Results of electron microprobe analyses of amphibole}


Appendix F: Results of electron microprobe analyses of amphibole

\begin{tabular}{|c|c|c|c|c|c|c|c|c|c|c|c|c|}
\hline Name & $\mathrm{SiO}_{2}$ & $\overline{\mathrm{TiO}_{2}}$ & $\overline{\mathrm{Al}_{2} \mathrm{O}_{3}}$ & $\mathrm{FeO}$ & MnO & MgO & $\mathrm{CaO}$ & 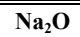 & 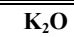 & $\bar{F}$ & 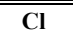 & Total \\
\hline$\overline{\text { WI-37-01-01 }}$ & 53.95 & 0.615 & 0.404 & 16.36 & 0.045 & 13.54 & 0.442 & 7.889 & 1.619 & 1.857 & 0.019 & 95.94 \\
\hline WI-37-01-02 & 54.39 & 0.497 & 3.185 & 16.61 & 0.000 & 10.28 & 0.578 & 7.833 & 1.445 & 1.069 & 0.023 & 95.45 \\
\hline WI-37-01-03 & 53.99 & 0.280 & 3.996 & 14.50 & 0.039 & 10.46 & 1.516 & 7.966 & 1.470 & 1.325 & 0.026 & 95.01 \\
\hline WI-37-01-04 & 54.77 & 0.368 & 0.472 & 18.29 & 0.077 & 12.39 & 0.432 & 7.381 & 1.503 & 1.609 & 0.030 & 96.63 \\
\hline WI-37-01-05 & 56.01 & 0.448 & 0.274 & 15.43 & 0.039 & 14.23 & 0.521 & 8.289 & 1.642 & 2.039 & 0.009 & 98.07 \\
\hline WI-37-01-06 & 54.43 & 0.982 & 0.394 & 16.23 & 0.019 & 13.10 & 0.500 & 7.804 & 1.593 & 2.156 & 0.033 & 96.32 \\
\hline WI-37-01-07 & 55.25 & 0.208 & 0.854 & 19.12 & 0.068 & 11.53 & 0.449 & 7.406 & 1.363 & 1.296 & 0.016 & 97.01 \\
\hline WI-37-01-08 & 55.49 & 0.805 & 0.346 & 15.21 & 0.029 & 14.09 & 0.416 & 8.179 & 1.600 & 2.173 & 0.007 & 97.43 \\
\hline WI-37-01-09 & 55.37 & 0.386 & 0.457 & 18.60 & 0.048 & 12.52 & 0.593 & 7.140 & 1.672 & 1.394 & 0.050 & 97.63 \\
\hline WI-37-01-10 & 56.00 & 0.270 & 0.190 & 15.29 & 0.076 & 14.19 & 0.639 & 8.750 & 1.578 & 2.175 & 0.003 & 98.24 \\
\hline WI-37-01-11 & 56.10 & 0.700 & 0.191 & 17.18 & 0.021 & 13.16 & 0.321 & 7.759 & 1.540 & 1.632 & 0.013 & 97.93 \\
\hline WI-37-01-12 & 55.60 & 0.224 & 0.225 & 16.62 & 0.035 & 13.52 & 0.535 & 8.015 & 1.597 & 1.822 & 0.000 & 97.43 \\
\hline WI-37-01-13 & 55.46 & 0.374 & 0.184 & 16.54 & 0.000 & 13.65 & 0.342 & 8.172 & 1.450 & 1.789 & 0.009 & 97.21 \\
\hline WI-37-01-14 & 55.56 & 1.245 & 0.266 & 15.17 & 0.040 & 14.15 & 0.422 & 8.272 & 1.599 & 1.763 & 0.000 & 97.75 \\
\hline WI-37-01-15 & 55.27 & 0.713 & 0.353 & 16.38 & 0.010 & 13.31 & 0.369 & 8.125 & 1.363 & 1.638 & 0.000 & 96.84 \\
\hline WI-37-01-16 & 55.57 & 0.248 & 0.166 & 15.51 & 0.060 & 14.13 & 0.592 & 8.386 & 1.717 & 2.109 & 0.008 & 97.60 \\
\hline
\end{tabular}




\section{Appendix G}

Results of electron microprobe analyses of pyroxene 


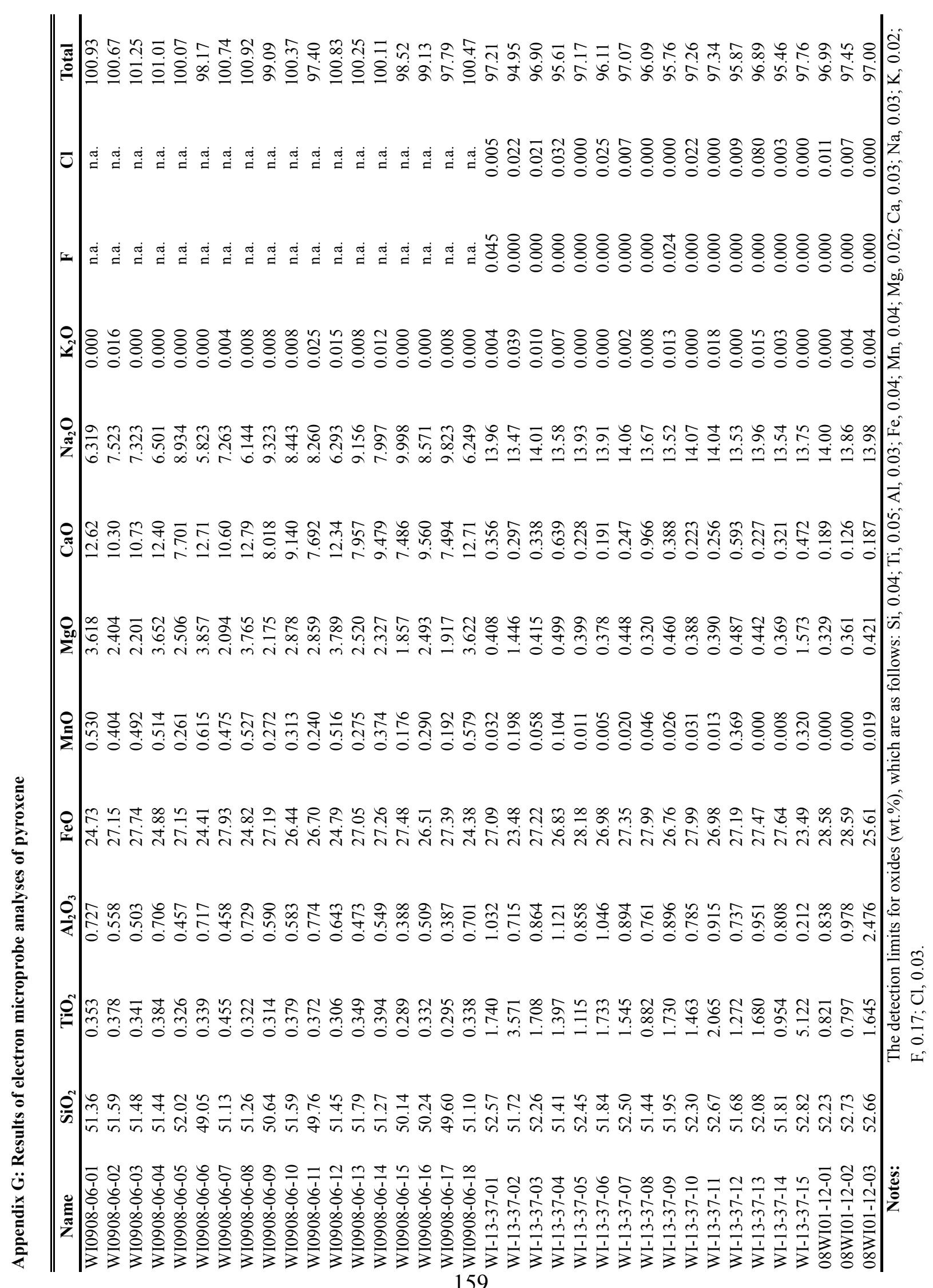

159 


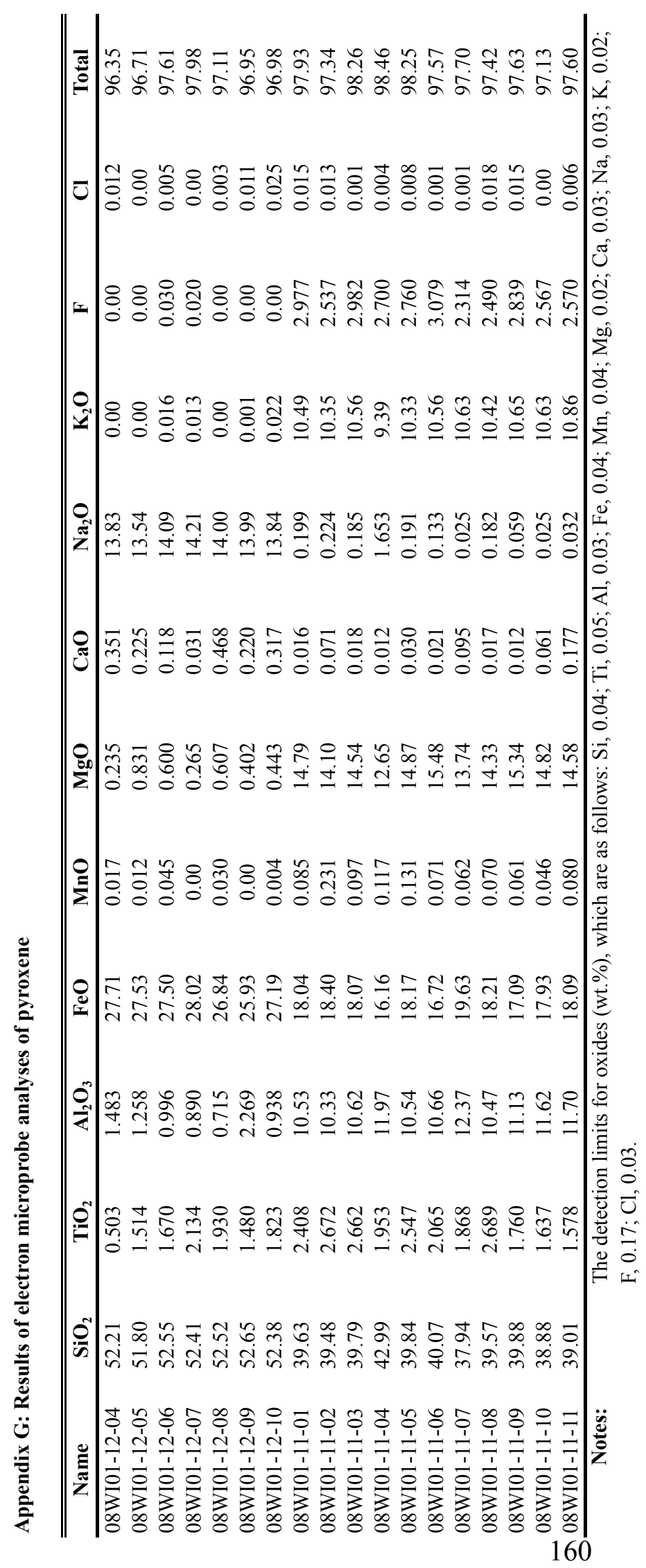




\section{Appendix $\mathbf{H}$}

Results of electron microprobe analyses of albite and potassium feldspar 


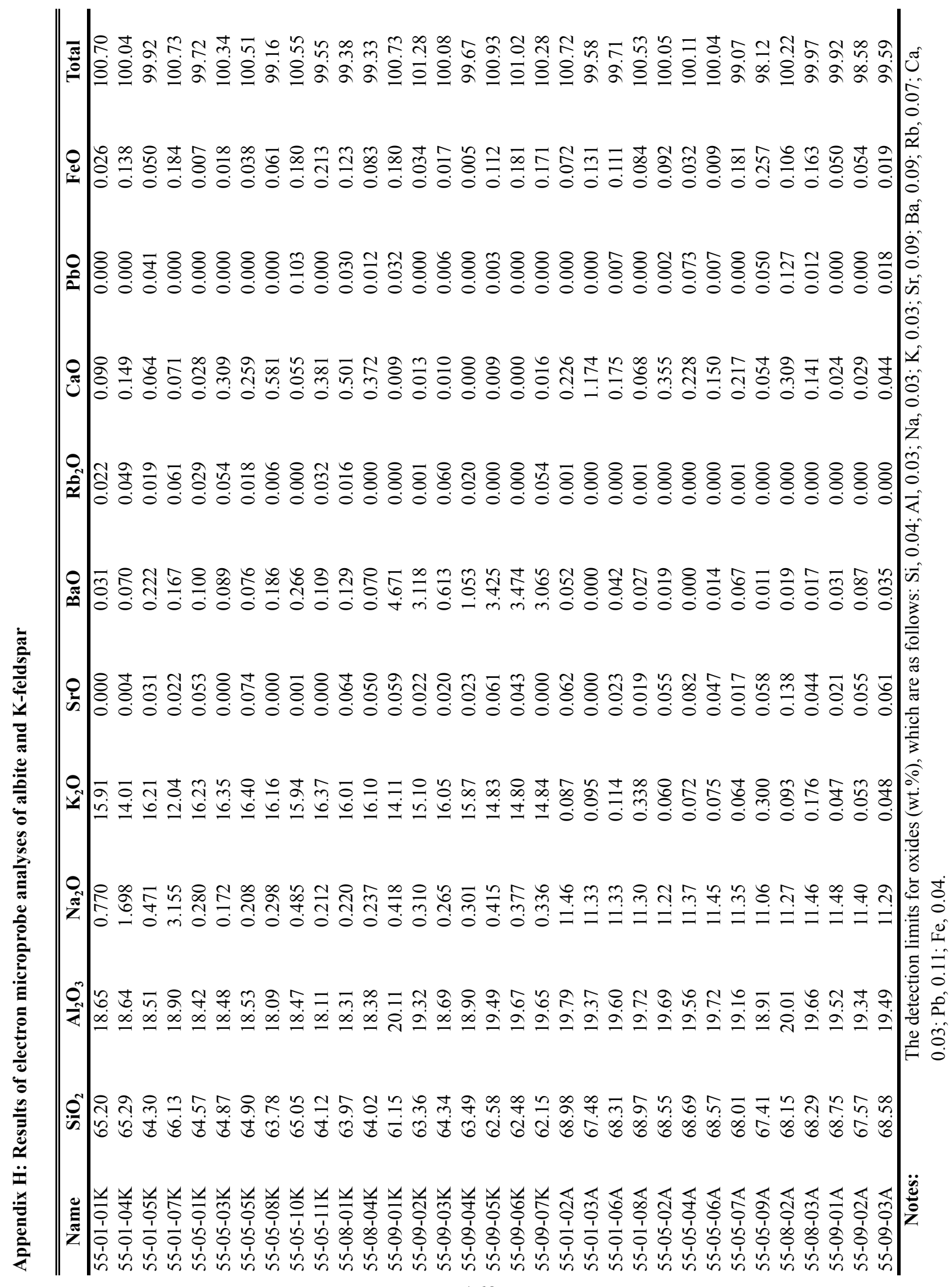

162 


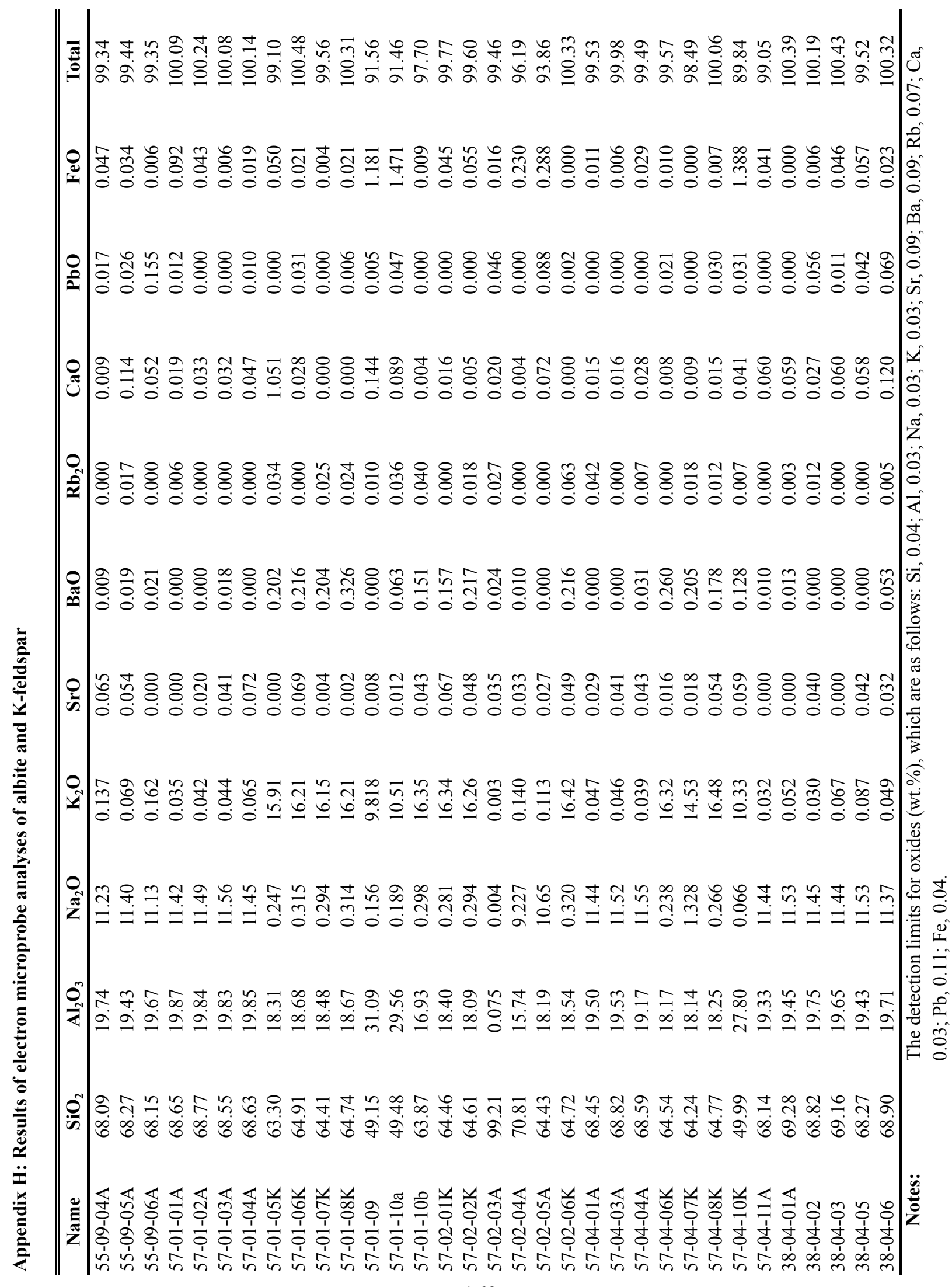




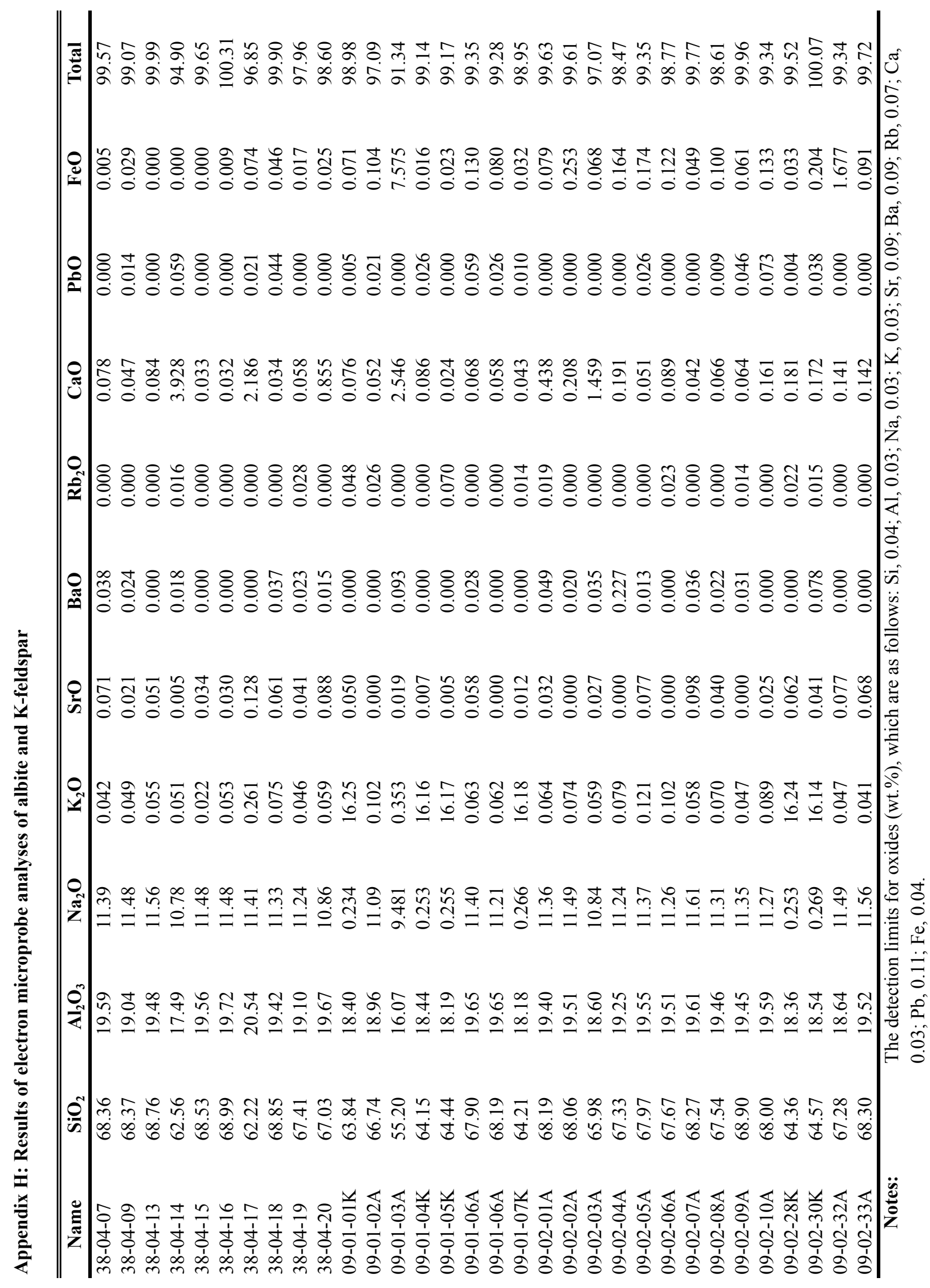




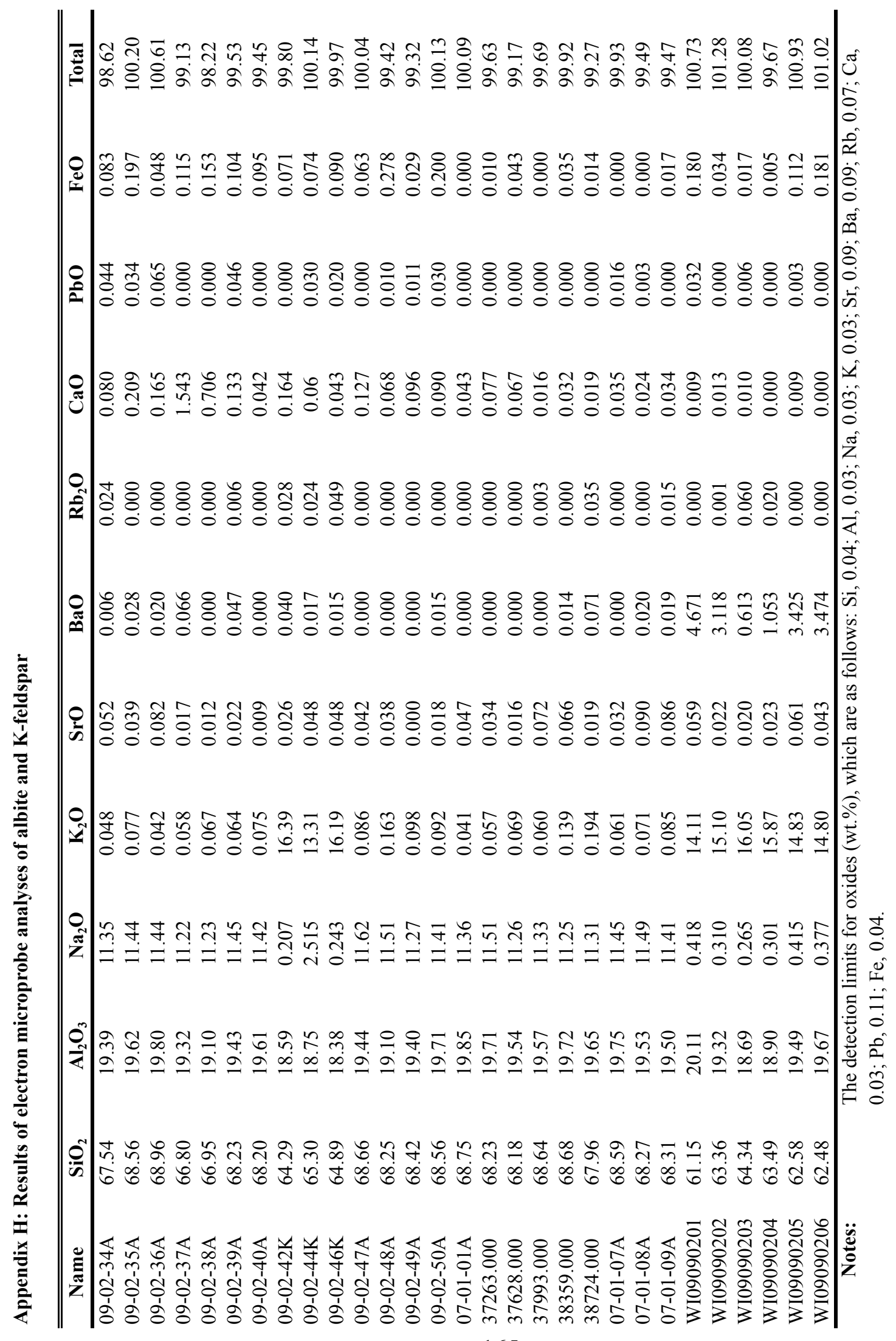




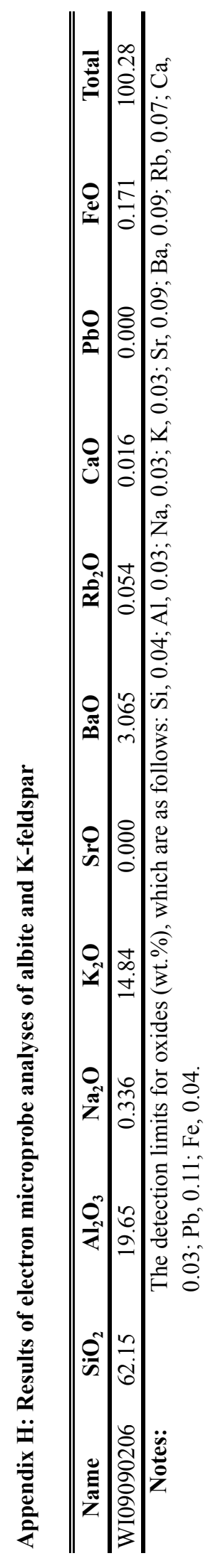


Appendix I

Results of electron microprobe analyses of apatite 


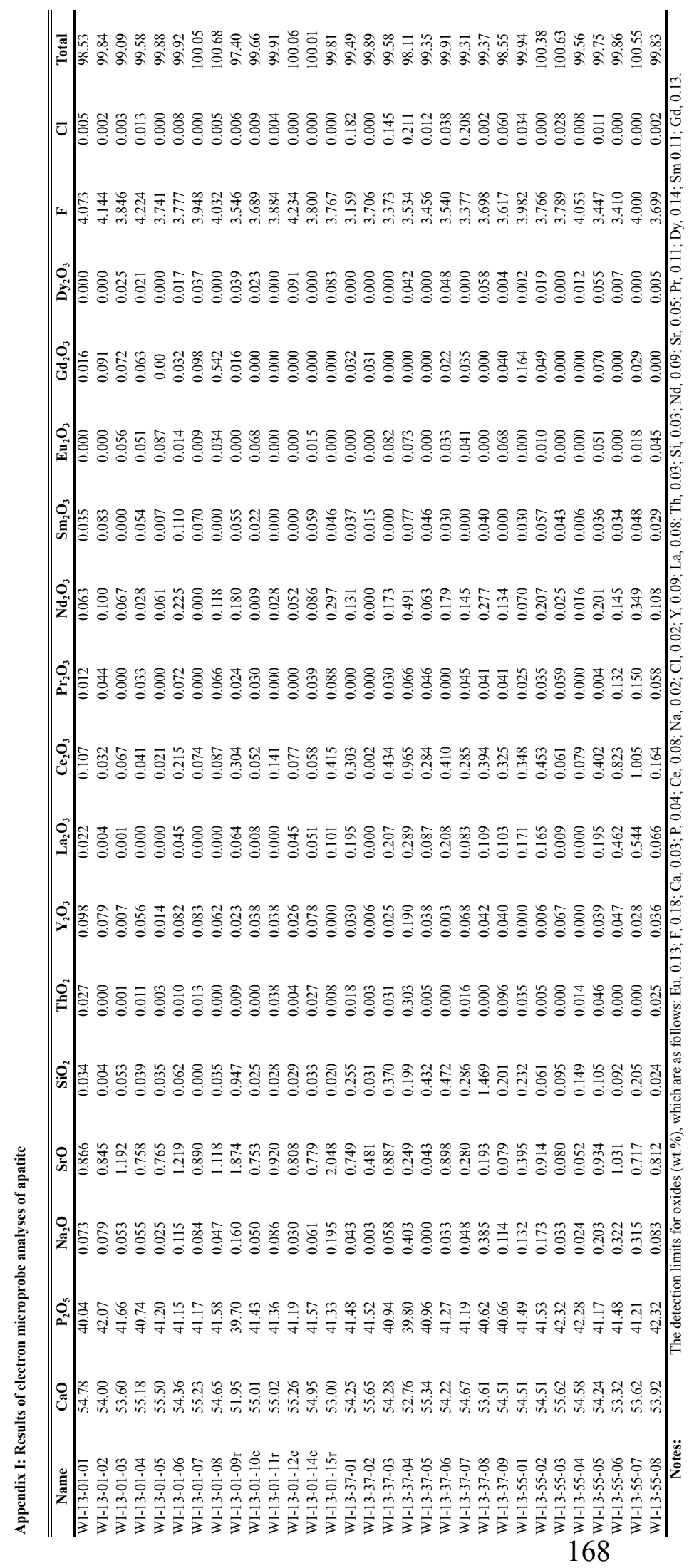




\section{Appendix J}

Results of electron microprobe analyses of bastnäsite-(Ce), parisite-(Ce), synchysite-(Ce), cordylite-(Ce), and ancylite-(Ce) 


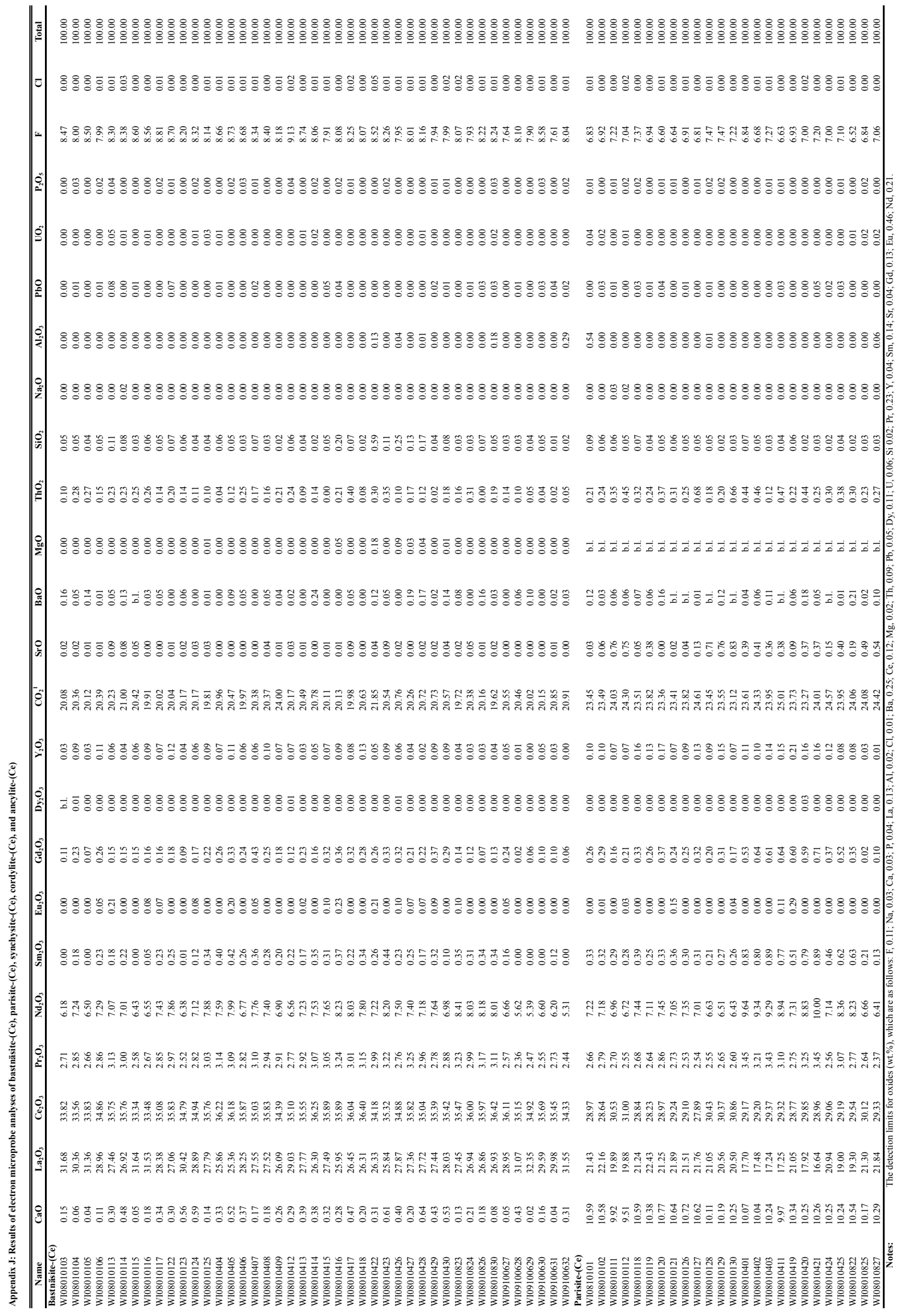

170 


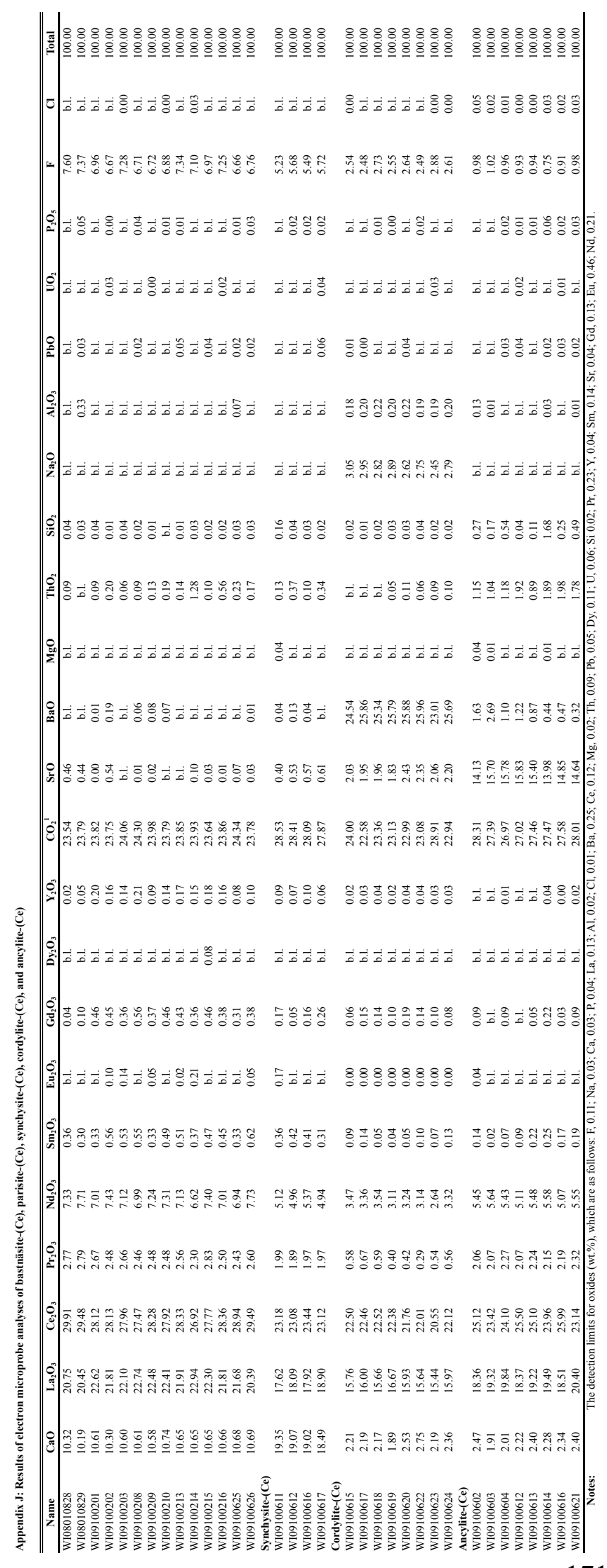


Appendix K

Results of electron microprobe analyses of monazite-(Ce) 


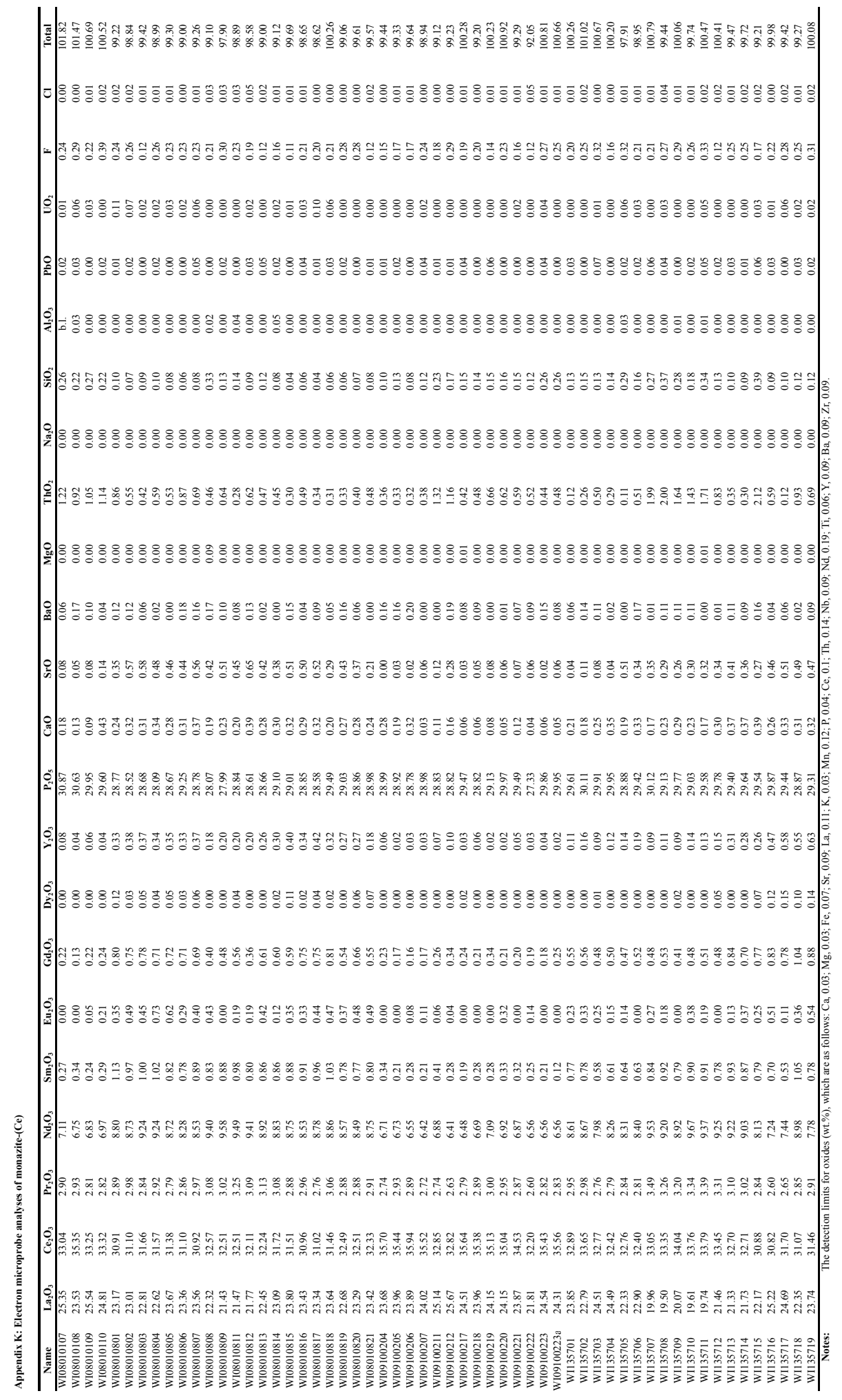

